\author{
Universidade de São Paulo \\ Instituto de Física \\ Instituto de Química \\ Instituto de Biociências \\ Faculdade de Educação
}

\title{
Construindo subsídios para a promoção da educação científica em visitas a laboratórios de pesquisa.
}

Graciella Watanabe 


\author{
Universidade de São Paulo \\ Instituto de Física \\ Instituto de Química \\ Instituto de Biociências \\ Faculdade de Educação
}

\title{
Construindo subsídios para a promoção da educação científica em visitas a laboratórios de pesquisa.
}

\author{
Graciella Watanabe
}

Orientadora: Profa. Dra. Maria Regina Dubeux Kawamura Co-Orientador: Prof. Dr. Marcelo Gameiro Munhoz

Dissertação de mestrado apresentada ao Instituto de Física, ao Instituto de Química, ao Instituto de Biociências e a Faculdade de Educação da Universidade de São Paulo, para a obtenção do título de Mestre em Ensino de Ciências Modalidade Física.

Comissão Examinadora:

Profa. Maria Regina Dubeux Kawamura (Presidente)

Prof. Marcos Nogueira Martins

Prof. Henrique César da Silva 
Autorizo a reprodução e divulgação total ou parcial deste trabalho, por qualquer meio convencional ou eletrônico, para fins de estudo e pesquisa, desde que citada a fonte.

FICHA CATALOGRÁFICA

Preparada pelo Serviço de Biblioteca e Informação do Instituto de Física da Universidade de São Paulo

\section{Watanabe, Graciella}

Construindo subsídios para a promoção da educação científica em visitas a laboratórios de pesquisa. São Paulo, 2012

Dissertação (Mestrado) - Universidade de São Paulo. Biociências

Faculdade de Educação, Instituto de Física, Instituto de Quimica e Instituto de

Orientador: Profa. Dra. Maria Regina Dubeux Kawamura

Co-Orientador: Marcelo Gameiro Munhoz

Área de Concentração: Ensino de Física

Unitermos: 1.Física - Estudo e Ensino; 2. Laboratórios

Científicos; 3.Espaço não Formal; 4. Educação Científica;

5. Alfabetização Científica 
"Orẫo se pode escrever nada com indiferenca"

Ssimone de Steauvoir 
Alos meus pais, pelos ensinamentos sobre a honestidade. Llo बvã, que far a vida ser mais livre. 


\section{Agradecimentos}

Não se escreve com indiferença, por isso agradeço aos meus orientadores, Regina e Marcelo, pessoas capazes de compreender, ouvir e estender a mão nos momentos difíceis. Por mais do que orientarem na academia, mostraram novos olhares e deram apoio para eu buscar o que acreditava.

Ao Ivã, por ser um amigo fiel, honesto e sincero; sobretudo quando foi preciso. Por ser um homem de caráter incontestável; capaz de dizer as coisas mais duras de maneira tão sensível. Obrigado por fazer da vida um lugar mais leve; mais feliz!

À minha mãe Ceuza e meu pai Shiroaki, por me ensinarem bons modos, educação, respeito aos mais velhos, sermos críticos e duros com as injustiças da vida e capazes de dar valor as coisas simples, que são as únicas importantes.

À Giselle, Sheyla e Luciana; que viveram a infância, adolescência e vida adulta; comigo. Por aprendermos juntas que família e amizade são como tempo e espaço na relatividade.

Aos meus sobrinhos Caio e Thales, por que é bom responder as questões mais complexas sobre as constelações e a formação das estrelas para vocês! Ao Gustavinho, que é um sobrinho ainda pequeno demais para compreender como a ciência é legal, mas que já tem talento para gostar disso.

À família Gurgel, que sempre dão apoio em tudo. Mas principalmente a dona Lourdes por acordar comigo às cinco da manhã para fazer café quando eu ia dar aula em Bragança e ao seu Armando, por contar boas histórias sobre tudo e aumentar meu capital cultural!

À minha amiga Jamille Lanutti que é sempre um porto seguro. A Andreza Conchetti por ser fiel a nossa amizade, por tanto tempo. A Fernanda Marchi, que é amiga para conversar sobre coisas da alma. Ao Bruno Franzon pela simplicidade, descanso e alegria; de ter com quem conversar pelo prazer da companhia. A Graça Betânia Moraes Hosokawa por ser um exemplo intelectual e de garra, companheira fiel.

As duas amigas inesquecíveis Fabiana Melo e Patrícia Nakagome, que me ensinaram muito sobre educação, amizade e companheirismo! Por irem aos lugares mais longínquos do mundo e sempre voltarem com boas histórias e por trabalharem muito por um mundo melhor.

À Roseline Strieder, que é uma amiga que tem ideias fantásticas e sempre está disposta a ajudar... Obrigado pelos muitos artigos enviados para "ver se ajuda 
no seu trabalho". À amiga Renata Ribeiro, por sempre ter um tempinho para conversar, dar conselhos e rir; sobre tudo: amizade, café, a Frida e a Anita e os gatinhos joselitos.

As meninas e ao menino: Paulinha, Carla, Soninha, Lígia, Bruna, Aninha, Marcília e Fred; pelas discussões produtivas.

Aos amigos de sempre: Nany, Fabiano, Alf, Aline, Patricia e Marcel.

Ao professor Luis Carlos de Menezes por ter se comprometido comigo no início desse trabalho, por me ajudar sempre carinhosamente quando pedi.

Ao professor Maurício Pietrocola, que sempre se dispôs a ouvir, dar conselhos e sugestões; ajudando-me a compreender mais sobre o ensino de física.

Ao professor Cristiano Mattos por dar sugestões valiosas na qualificação e nos papos diários que fazem o trabalho ficar mais leve!

A professora Cristina Leite que me acolheu no início do mestrado, dando apoio e indicando caminhos para o processo de me reconhecer nesse programa de pós-graduação.

Ao professor Henrique César Silva que buscou compreender o trabalho quando ele ainda era difícil de entender, dando sugestões preciosas para ajudar a transformá-lo.

Ao professor Manoel Robilotta, que me ensinou muito sobre física e mais ainda sobre o que é ser pesquisador.

A professora Nobuko Ueta que sempre esteve disposta a ajudar com as visitas, dando sugestões e trazendo reflexões para melhorar nosso material.

Aos meninos do laboratório de eletrotécnica do Pelletron: Vitório, Udo, Fabinho, Evandro, Messias, Silvio e Tromba pelas felizes tardes de conversa e os muitos ensinamentos que me ajudaram a escrever esse trabalho.

Ao Prof. Marcos Nogueira Martins pelas contribuições na defesa, apontando caminhos para melhorar o trabalho no futuro.

Aos professores Nemitala Added e Nilberto Medina, que no início do trabalho sentaram comigo, explicaram pacientemente sobre o acelerador, por dividirem experiências valiosas para que eu pudesse compreender o que é estar no Pelletron. 
Ao Renato por estar sempre disposto a ajudar nas visitas, mesmo que isso implicasse perder o sábado. Aos amigos da USP: Vanessa, Tassiana, Felipe, Jorge, Alexandre, Flávia, Roberto, Esdras, Glauco, Jackeline, Valéria, Thiago e Leika.

Ao Thomas que não mediu esforços para fazer as coisas andarem, sempre educado e amigo!

E finalmente, obrigado à Legião Urbana, por que ouvir a Tempestade foi calmaria nos momentos de desespero!

A CAPES pelo apoio financeiro. 


\section{Sumário}

RESUMO

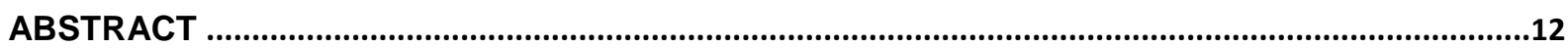

APRESENTAÇÃO

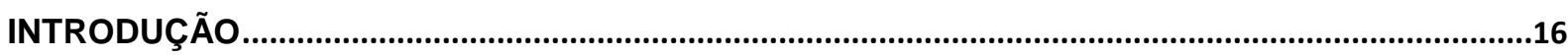

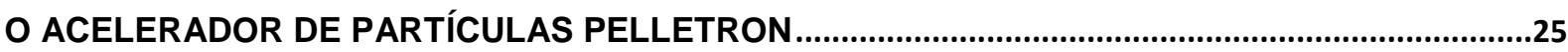

1.1. ProblematizaÇÃo ACERCA doS ACELERAdORES de PARTíCULAS ...............................................26

1.2. O FUNCIONAMENTO DO ACELERADOR PELLETRON: ESTRUTURA GERAL E O LOCAL......................29

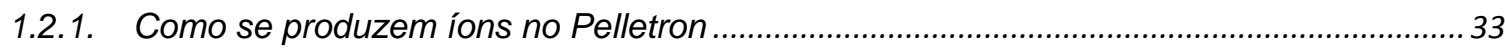

1.2.2. Como se aceleram feixes de íons...................................................................................... 35

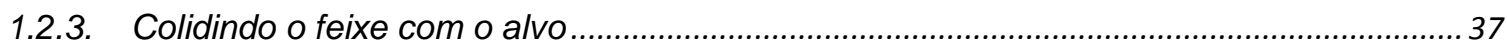

1.3. O CAMPO CIENTÍFICO DO ACELERADOR PELLETRON (TRABALHOS DESENVOLVIDOS)...................39

1.4. O CAMPO INSTITUCIONAL DO ACELERADOR PELLETRON................................................................4

OS ESPAÇOS NÃO FORMAIS DE ENSINO E O PAPEL DA MEDIAÇÃO …........................................44

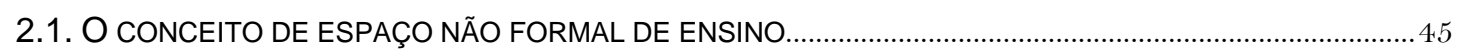

2.2. OS ESPAÇOS NÃO FORMAIS NO ENSINO DE CIÊNCIAS.......................................................................

2.3. OS MUSEUS E AS MEDIAÇÕES NOS ESPAÇOS NÃO FORMAIS ………………………...................6

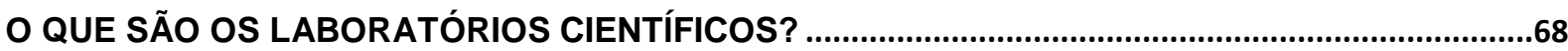

3.1. A PERCEPÇÃO DA SOCIOLOGIA DA CIÊNCIA SOBRE OS LABORATÓRIOS CIENTÍFICOS ........................69

3.2. OS LABORATÓRIOS DE PESQUISA NO CAMPO DA EDUCAÇÃO EM CIÊNCIAS ………………................. 74

3.3. A INSERÇÃO DO LABORATÓRIO PELLETRON NO CAMPO EDUCACIONAL ................................................76

PERSPECTIVAS DE ATUAÇÃO PEDAGÓGICA NOS LABORATÓRIOS CIENTíFICOS....................81

4.1. RECONHECENDO OS OBJetiVos/PROCESSOS da AlFABETIZAÇÃo CIENTífICA E TECNOLÓGICA.82

4.2. RECONHECENDO OS OBJETIVOS DO MOVIMENTO CTS.. .91

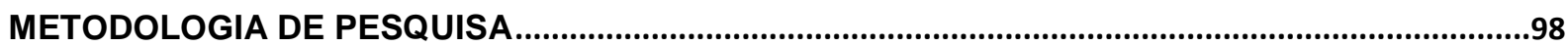

5.1. A METODOLOGIA QUALITATIVA: UMA BREVE DISCUSSÃO DE SEUS PROBLEMAS .................................99

5.2. A METODOLOGIA QUALITATIVA: UMA BREVE DISCUSSÃO DE SUAS PERSPECTIVAS..........................103

5.3. NORTEANDO OS CAMINHOS: OS MÉTODOS E ESTRATÉGIAS NA COLETA DE DADOS .........................105

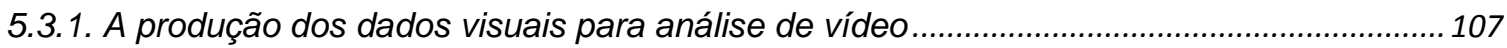

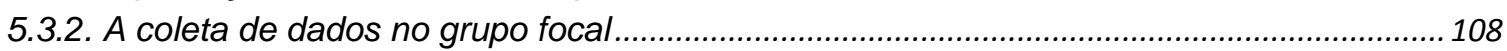

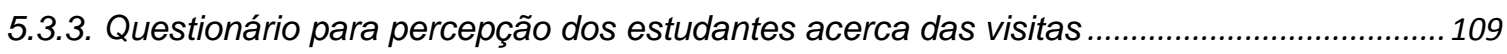

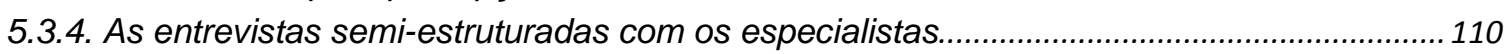

5.3.5. O método etnográfico na entrada no campo de pesquisa................................................... 111

5.4. NORTEANDO OS CAMINHOS: AS DIMENSÕES DE ANÁLISE DOS DADOS ................................................112

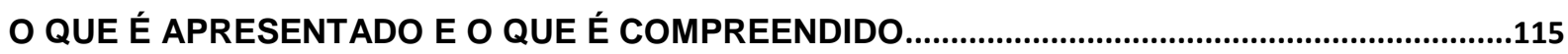

6.1. O UNIVERSO DA CIÊNCIA DO LABORATÓRIO QUE É APRESENTADO PARA O PÚBLICO. ....................116

6.1.1. Site do Laboratório Aberto de Física Nuclear................................................................ 116

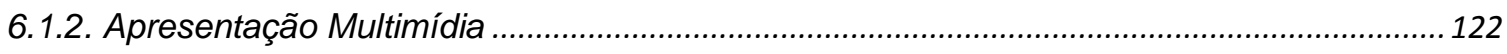

6.1.3. Protótipo 0,33 UD: o modelo do terminal de aceleração ................................................... 127

6.1.4. Apresentação de uma visita com professores da escola básica.........................................1 130

6.2. O OLHAR DOS PROFESSORES E ALUNOS PARA O QUE É APRESENTADO SOBRE O LABORATÓRIO.136 


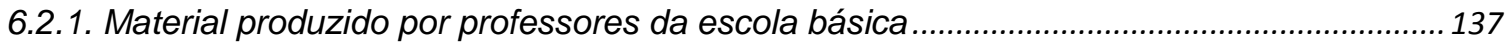

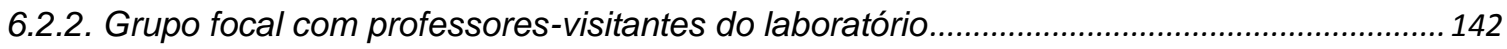

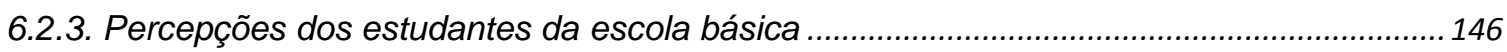

6.3. O OLHAR DOS CIENTISTAS PARA O QUE É APRESENTADO SOBRE O LABORATÓRIO. .......................150

6.4. UM BREVE RELATO DAS EXPERIÊNCIAS VIVIDAS NO LABORATÓRIO .................................................156

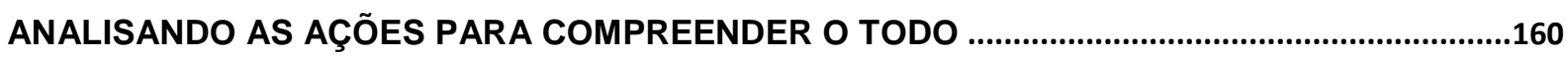

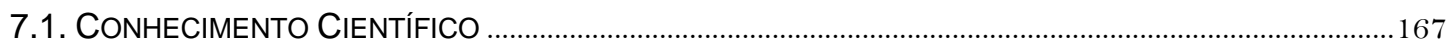

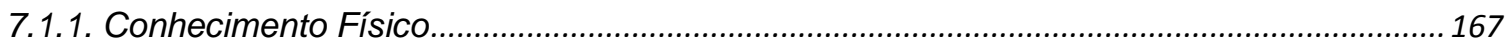

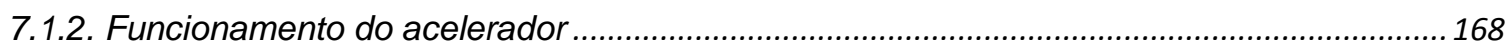

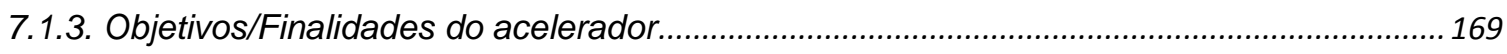

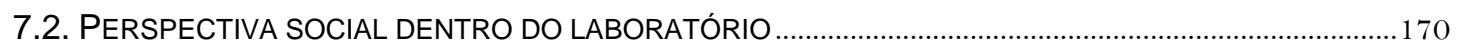

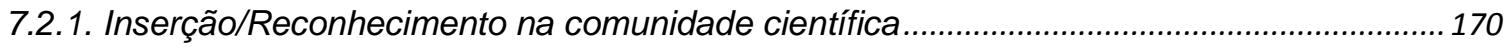

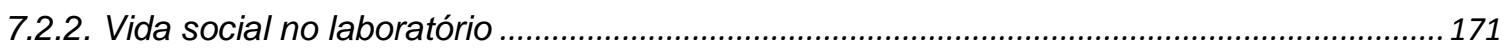

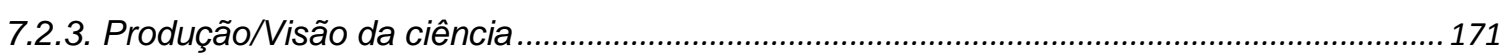

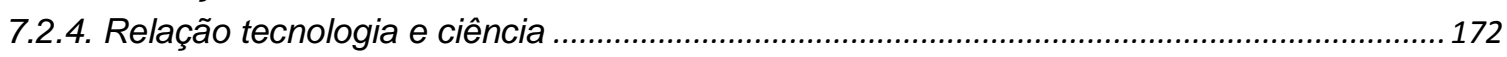

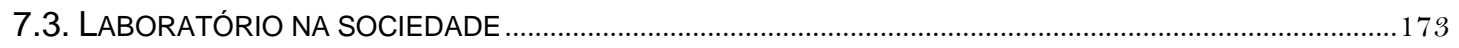

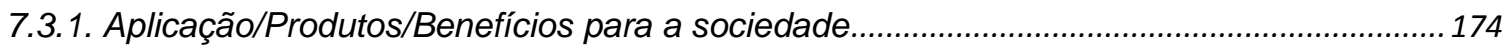

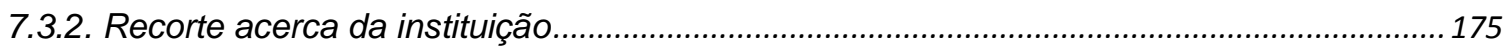

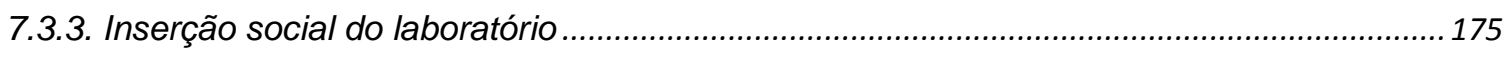

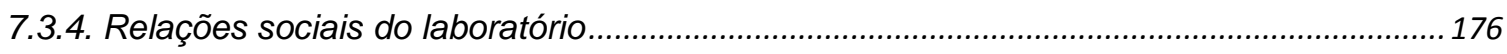

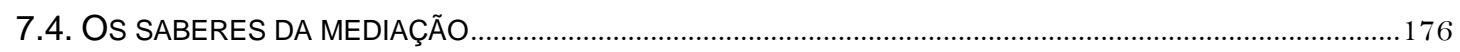

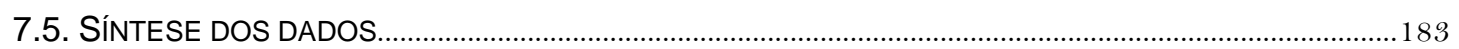

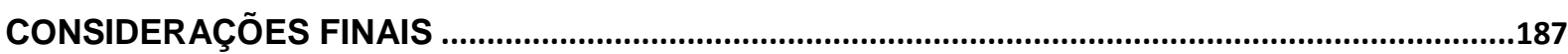

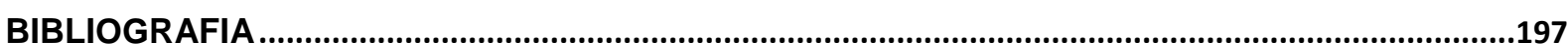

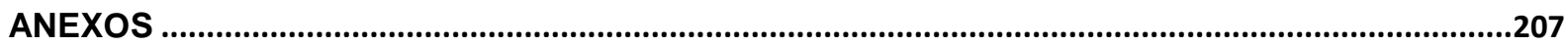




\section{Resumo}

WATANABE, G. Construindo Subsídios para a Promoção da Educação Científica em Visitas a Laboratórios de Pesquisa. 2012. 207 f. Dissertação (Mestrado em Ensino de Física) - Instituto de Física - Instituto de Química - Instituto de Biociências - Faculdade de Educação - Universidade de São Paulo, São Paulo, 2012.

O trabalho apresentado investiga as contribuições da pesquisa em ensino de ciências para a promoção da educação científica em atividades a serem desenvolvidas por laboratórios ativos de pesquisa. Apoiado nos debates sobre o ensino em espaços não formais, procura situar o ambiente de trabalho desses centros e suas possibilidades de interlocução com a escola básica e o público em geral. Tal perspectiva localiza as limitações desses laboratórios, reconhecendo a não intencionalidade própria dos espaços envolvidos, ao contrário do que se observa, por exemplo, em museus ou exposições científicas. Por outro lado, identifica sua singularidade, enquanto ambiente privilegiado para apresentar os processos de produção científica, enfatizando os aspectos sociais de seu fazer, pouco explorados no contexto escolar. Com esse intuito, foram analisadas as possíveis contribuições de reflexões sobre Alfabetização Científica e CiênciaTecnologia-Sociedade (CTS), a fim de inserir articulações entre os aspectos do conhecimento científico presentes nos laboratórios e as demandas de visitantes. Em particular, investiga-se o acelerador de partículas Pelletron, do Departamento de Física Nuclear do IFUSP, analisando diferentes estratégias associadas a visitas, desenvolvidas ao longo de seis anos de trabalho, com a finalidade de promover a educação científica. Nessas análises, foi possível identificar que os diferentes protagonistas, sejam eles alunos, professores, cientistas ou técnicos, manifestam interesses nem sempre convergentes. Isso conduziu ao questionamento da centralidade atribuída ao conhecimento físico conceitual, procurando ampliar a ideia de conhecimento de forma a incluir outras dimensões do fazer científico. Nessa direção, discute-se o potencial de dimensões do conhecimento relacionadas à produção da ciência e sua função social. Propõe-se, assim, que o conhecimento físico se articule com situações da dinâmica da vida do laboratório e com as questões de inserção da ciência no conjunto da sociedade, ampliando a compreensão dos visitantes acerca da ciência.

Palavras chave: laboratórios científicos; espaço não formal; educação científica; CTS e alfabetização científica. 


\begin{abstract}
WATANABE, G. Discussions regarding the Promotion of Science Education during Visits to Research Laboratories. 2012. 207 f. Dissertation (Master in Physics Education) - Physics Institute - Chemistry Institute - Biology Institute Education Faculty - University of São Paulo, 2012.

The present study investigates the contributions of research in science learning to promote science education activities to be developed by operational research laboratories. Supported by discussions regarding the non-formal education, this study aims to situate the work environment of these laboratories and their potentialities of communication with elementary schools and the general public. This endeavor must recognize the limitations of these laboratories, since they have a different purpose when compared to museums and science exhibitions, for instance. On the other hand, it is possible to identify the uniqueness of such places as a privileged environment to present the science production process and the social aspects of this process, that is little explored in the school context. In addition, we analyzed the possible contributions of reflections on Scientific Literacy and ScienceTechnology-Society (STS), in order to insert links between aspects of scientific knowledge in the laboratories and the demands of visitors. In particular, we investigate the Pelletron particle accelerator, from the Department of Nuclear Physics of the Institute of Physics from the University of São Paulo (IFUSP), analyzing different strategies associated with the visits developed over six years of work, in order to promote science education. In these analyses, it was possible to identify that the different actors, such as students, teachers, scientists or technicians, express different interests that do not always converge. This led to challenge the central role attributed to conceptual physical knowledge, seeking the broadening of the idea of knowledge in order to include other dimensions of scientific work. In this sense, we discuss the possible dimensions of knowledge related to the production of science and its social function. Therefore, we propose that the physical knowledge must be linked to other aspects of the laboratory dynamics and to issues regarding the insertion of science in the society, expanding visitors' understanding about it.
\end{abstract}

Keywords: science laboratories; non-formal space; science education; STS and scientific literacy. 


\section{Apresentação}

Chestre nã̃o é quem sempre ensina, mas quem de repente aprende

Guimarães Q Qosa

O trabalho aqui apresentado teve como embrião as atividades por mim desenvolvidas em uma iniciação científica, junto ao Departamento de Física Nuclear, do Instituto de Física da USP. Com o intuito de apresentar aos alunos, visitantes e curiosos, as atividades desenvolvidas no acelerador de partículas Pelletron, desse departamento, alguns professores desenvolveram, por iniciativa própria, apresentações que pudessem levar a um público mais geral as pesquisas produzidas no laboratório.

No entanto, devido às demandas crescentes de visitantes da escola básica, tornou-se, também, necessário procurar desenvolver apresentações que dialogassem com este novo público e que pudessem dar maior sentido ao conhecimento escolar trazido por estes estudantes. Assim, em meados de 2006, participando do Programa Ensinar com Pesquisa, da Pró-Reitora de Graduação da Universidade de São Paulo, desenvolvi a iniciação científica que viria a se tornar a motivação central das reflexões aqui apresentadas.

Nessa época, juntamente com o Prof. Marcelo Munhoz, responsável pelo projeto, nosso ponto de partida foi procurar indagar sobre $O$ quê? e Como? poderiam ser apresentados os assuntos aos estudantes da escola básica em visitas ao laboratório Pelletron. Nesse percurso, foram feitas diversas entrevistas com professores, engenheiros e técnicos; para juntos pensarmos sobre as possibilidades de produção de visitas monitoradas ao acelerador. Concomitante a esse trabalho, foi desenvolvido, junto com os técnicos no laboratório de eletrônica, o protótipo 0,33 UD, que viria a ser uma maquete do terminal do acelerador, em que se buscava demonstrar o funcionamento do mesmo. De forma geral, a busca por uma aprendizagem dos conceitos científicos e seu aparato tecnológico sempre permearam as atividades naquele momento. Acreditávamos que, dessa forma, 
estaríamos proporcionando uma visão de aspectos culturais mais amplos, juntamente com a aquisição de tais conhecimentos. Na nossa compreensão inicial, portanto, o próprio conhecimento científico e tecnológico se constituía em aspectos culturais. Com essa perspectiva, foi produzida uma apresentação multimídia com as pesquisas desenvolvidas no laboratório, assim como os conceitos científicos associados ao currículo da escola média que poderiam dar uma explicação do funcionamento do acelerador. Além disso, em parceria com a empresa Júnior da FEA - USP foram desenvolvidos um site e panfletos sobre as visitas ao laboratório, apresentando de maneira sucinta alguns conceitos básicos de física nuclear.

Contudo, durante as primeiras visitas dos estudantes das escolas públicas de São Paulo, houve um momento de desânimo e dúvida sobre a qualidade e efetividade de tais práticas dentro do laboratório. Não observamos uma receptividade tão positiva, por parte dos alunos, tal como esperávamos. As visitas não pareciam causar o impacto planejado, não conseguiam proporcionar o encantamento com a ciência que, de certa forma, buscávamos.

Foi na interlocução com a área em Ensino de Física e nas leituras sobre a temática que começaram a surgir possibilidades para um novo desenho das atividades, que foram, então, reformuladas. Ainda assim, no entanto, muitas lacunas não seriam de todo preenchidas, naquele momento, constituindo-se no início das questões apresentadas nesse trabalho.

Assim, uma pergunta merece destaque por se tornar efetiva do problema de pesquisa, mesmo que indiretamente, e que proveio de uma percepção como pesquisadora ao acompanhar as visitas: Qual deveria ser o elemento motivador, para os alunos, de vir conhecer um laboratório de pesquisa, e que pudesse transformar as visitas em mais do que apenas uma atividade recreativa? Neste sentido, o percurso de produção de trabalhos para eventos da área de Ensino, nos anos seguintes, possibilitou discussões que trouxeram diversas contribuições para se desenhar uma possível resposta para tal questão: a existência de diferentes formas de entendimento do conhecimento da física, ainda mais diversificadas quando a física é considerada enquanto cultura. 
Foi com o aprofundamento dos estudos sobre aspectos da cultura que se percebeu que o entendimento do termo não possibilitaria abarcar toda a complexidade do objeto estudado. Em outras palavras, aquilo que se entendia como cultura, em sua concepção mais abrangente, não dava conta de todas as nuances do conhecimento científico que extrapolava o conteúdo físico. Ainda no decorrer do processo de visitas e cursos ministrados em função do trabalho de iniciação científica, recuperamos a presença de questões dos estudantes sobre aspectos éticos, sociais, morais, políticos que, na perspectiva inicial de trabalho, não se dava conta de responder. Neste sentido, novas demandas foram aparecendo durante todo o percurso e sendo exploradas no decorrer de nossa reflexão atual.

Assim, o projeto aqui apresentado busca aprofundar essas questões trazendo uma discussão sobre o papel das visitas em laboratórios científicos e suas potencialidades, como instrumentos de reconhecimento do fazer científico e como componente social de uma comunidade. Mais que isso, busca dar conta de uma dimensão do fazer científico que não pode ser apresentado pela escola básica, seja pela dificuldade do ambiente físico, como da própria impossibilidade de imersão mesmo que de maneira pouco profunda - em uma ciência em seu processo e ambiente de construção.

Partindo de uma visão de educação científica em uma perspectiva mais ampla, na qual procuramos adentrar, infere-se o potencial de uma postura mais abrangente e menos pragmática para nossos objetivos. Trata-se de buscar uma apresentação da ciência enquanto fruto de uma consciência humana, imersa em regras estabelecidas por um grupo cultural repleto de valores, interesses e criatividade; que juntos produzem um apanhado de saberes pouco trivial. E quando apresentado a um contexto escolar ou grupo distinto de sua origem, o conhecimento científico apenas pautado no conteúdo físico se limita a uma dimensão abstrata que pouco significa para aqueles que o recebe. 


\section{Introdução}

(S) Poronel Alureliano Buentia arranhou durante muitas horas, tentando rompétla, a dura casca da sua solidão (...) Tivera que promover 32 guerras, e tivera que violar todos os seus pactos com a morte e fucar como um porco na estrumeira da glória, para descobrir com quase quarenta anos de atraso os privilégios da simplicidade.

É consenso, entre os pesquisadores da área de ensino de ciências, que a educação escolar passa por um momento delicado, seja pelas dificuldades apresentadas pelos estudantes na aprendizagem dos conteúdos escolares ou pela pouca procura dos cursos relacionados às áreas de exatas das graduações. Talvez as mais graves conseqüências de tais resultados sejam a grande responsabilidade que recai sobre a escola básica na formação de estudantes mais preparados para as carreiras científicas (FOUREZ, 2006) ou na ilusória pretensão de que os investimentos em pesquisas acadêmicas sobre educação poderão sozinhos, elevar o Brasil em rankings educacionais mundiais. Fato este que sabemos ser também propenso às questões políticas, econômicas, sociais e, talvez mais grave ainda, culturais.

Nesse mesmo quadro, não é estranho ouvir insistentemente: Estudar Física Para Quê? Ainda, se não for ciência aplicada, estatística ou algo voltado para a economia de mercado, parece que o conhecimento deixa de ter valor em nossa cultura, impregnada de uma visão utilitarista. Assim, o problema da educação científica precisa deixar de ser um problema dos educadores e - mais grave - dos educandos, para passar a ser objeto de debate de diversas esferas sociais (FOUREZ, 2006). Essas esferas, em nosso caso, podem ser compreendidas de forma a incluir também outros agentes do conhecimento científico (cientistas, técnicos, centros de pesquisas, agentes financiadores etc.). 
Desse contexto, surge como assunto recorrente entre os pensadores em ensino de ciências que a importância de se tornarem públicas as descobertas e avanços científicos não se remete apenas a uma responsabilidade ética e política dos cientistas. Mas, também, a uma necessidade de expansão da cultura científica para uma parcela efetivamente grande da sociedade, que não reconhece a produção da ciência como um bem econômico, político e social. Para Jean-Marc Lévy-Leblond (2004), o maior infortúnio da grande separação entre os pesquisadores de laboratório e os leitores de vulgarização seria o isolamento da ciência evocando a comunicações incertas e frágeis, necessitando de numerosas retransmissões nas quais se introduzem necessariamente ruídos e confusões (LEBLOND, 2004:41; tradução livre).

Para Osborne (2003):

(...) 0 crescente distanciamento e ambivalência relativamente à ciência ameaça a relação da ciência com seus públicos. A desconfiança pública na perícia científica corre o risco de colocar restrições indesejáveis à investigação e ao desenvolvimento tecnológico futuro. O receio do pior levará o público a exigir uma aplicação ingênua à investigação científica do chamado princípio da precaução, limitando potencialmente os avanços que a ciência oferece para resolver a abundância de problemas que a nossa sociedade enfrenta (OSBORNE, 2003)

Assim, o papel da divulgação científica ganhou novas formas de compreensão que abarcam não só a concepção de apropriação do conhecimento científico per se, para uma recriação com função de torná-lo acessível ao público (MORA, 1998). Mas, também, a reconhece como um conjunto de saberes associados à própria produção do conhecimento científico, sua formulação e como ele circula na sociedade atual. Algumas tentativas de divulgação, apesar de, na atualidade, ganharem grandes proporções no âmbito de jornais, revistas, livros, documentários, etc., na medida em que se restringem a informações científicas, passam a ser consideradas apenas como aportes de disseminação do conhecimento (SILVA, 2006). 
A interlocução unidirecional atrelada a esse tipo de disseminação remete ao cientista ou jornalista, o papel da apresentar um conhecimento ao público leigo sem levar em conta o papel da interação. É de suma importância que uma perspectiva de diálogo esteja clara no entendimento da divulgação científica, pois evoca compreendê-la para além da exposição "simplificada" do conhecimento. Para Silva:

O cientista pode sair do seu lugar "próprio" de interlocução legitimada com outro cientista para produzir interlocuções com outros leitores, não cientistas. Esse lugar é preciso não ser confundido, é preciso ser diferenciado. A expressão "divulgação científica" cumpre esse papel (SILVA, 2006: 58).

Em termos mais abrangentes, implica em compreender que o discurso da divulgação científica não é apenas a exposição do conhecimento provindo dos resultados obtidos pela ciência, mas reflete seu saber e sua produção (ALMEIDA, 2010). Assim, o cientista pode se reconhecer, na prática educacional, como interlocutor ou facilitador do diálogo entre conhecimento produzido e o relacionado.

No ensino de física, na tentativa de apresentar a produção do conhecimento científico, exposições interativas ou museus científicos emergem no Brasil como os principais agentes disseminadores e objetos de pesquisa da divulgação científica (CHINELLI \& AGUIAR, 2009; COLOMBO JR et. al., 2009). No entanto, o que parece ser um passo adiante em discussões que transcendem as pesquisas em divulgação científica é a defesa da importância do diálogo entre os espaços não-formais e a sala de aula (CHAGAS, 1993; PÉREZ \& MOLINÍ, 2004; LEAL \& GUARACIRA, 2001, 2002; ROCHA E GARCIA, 2008). Alguns trabalhos começam a tomar fôlego dentro da pesquisa em ensino de física ao defenderem a interface academia e escola básica, mais especificamente, a interação pesquisadores/docentes na produção de programas de investigações em museus para professores e alunos. Um exemplo disso são os trabalhos desenvolvidos pelos pesquisadores do Departamento de Física Aplicada da Universidade del País Vasco e o museu de ciência Kutxaespacio na Espanha, centralizando os processos investigativos nos conteúdos escolares que são ministrados pelos docentes das escolas básicas no momento das visitas (GUISASOLA et. al., 2005) e a participação de alunos e professores universitários 
na seleção e apresentação de conteúdos a serem divulgados em eventos científicos para a comunidade escolar (COUTINHO-SILVA et. al., 2005).

Para além da divulgação científica, a investigação do presente trabalho também se remete a outras questões, também alvo de atenção nas preocupações atuais da pesquisa em ensino de física: o ensino de física moderna e a ciência nacional.

No âmbito dos conteúdos modernos de física, diversos trabalhos enfatizam a necessidade de atualização curricular com temas contemporâneos e sua maior interação com o desenvolvimento tecnológico a ele atrelado (PINTO \& ZANETIC, 1999; SIQUEIRA, 2006; SANTOS-NETO, 2007; GARCIA, 2009). Nessa perspectiva, a física nuclear e de partículas ganha status no que tange à sua possibilidade de compreender o conhecimento científico em esferas que vão além do pragmatismo didático, com um grau de abstração mais elevado, fornecendo subsídios para reconhecer a ciência como uma atividade criativa e consequentemente, uma produção cultural.

Paralelamente, há também uma preocupação em trazer questões que enfatizem o conhecimento produzido na esfera nacional e sua relação intrínseca com a física moderna e contemporânea. No entanto, a ausência de uma identidade científica nacional bem definida e o não reconhecimento dos indivíduos nela inseridos torna a ciência algo relativamente estranho para esses sujeitos; fazendo parte de outra esfera social e cultural que não a deles.

Por outro lado, e de maneira bem geral, observa-se nos trabalhos sobre ensino de física moderna, divulgação científica e laboratórios científicos uma tendência por centrar a preocupação ou apelo pela contextualização e aprendizagem do conteúdo escolar. Nesses casos, tais propostas perpassam superficialmente ou deixam de considerar os processos de produção do conhecimento físico como componente social e cultural, na formação dos estudantes. Dessa forma, apontam para uma aprendizagem muitas vezes destituída de significados ou valores, de suas relações sociais, políticas e econômicas, que ficam mascaradas quando o conhecimento é apresentado apenas em seu corpo teórico. Essa postura também delega aos meios midiáticos o papel de apresentar as 
questões sociais da ciência, mas deixando ao cargo dos estudantes a tarefa de articulação com o conhecimento científico.

Assim, em nossa perspectiva, a procura por uma educação científica deve ser pautada em uma mudança mais ampla, como lembram Macedo e Katzkowicsz (2003), onde:

Este processo de mudança deve estar baseado em uma nova relação entre ciência e sociedade, que só poderá existir se todos os cidadãos e cidadãs possuírem formação e cultura científica que lhes permitam compreender e administrar sua vida cotidiana, enfrentá-las e integrar-se a ela de maneira crítica e autônoma, estando capacitados a tomar decisões. (MACEDO \& KATZKOWICS, 2003: 69)

Essa necessária mudança implica em reconhecer a ciência também como uma cultura, ou seja, um conhecimento provindo de um contexto histórico e social, pautado em regras estabelecidas por uma comunidade além de sua dimensão humana de criação. Para alcançar esse entendimento da ciência de maneira complexa, cabe uma reflexão sobre o sentido da cultura científica, que vai além da compreensão do conceito per se de cultura.

Tal demanda demonstra que o reconhecimento de espaços de produção científica são importantes aliados para essa nova educação a que almejam educadores e pesquisadores: uma educação científica capaz de promover uma emancipação dos estudantes, requerendo uma postura ética e moral em suas tomadas de decisão. Como lembra Forquin (1993)

Educar, ensinar, é colocar alguém em presença de certos elementos da cultura a fim de que ele deles se nutra, que ele os incorpore à sua substância, que ele construa sua identidade intelectual e pessoal em função deles. Ora, um tal projeto repousa necessariamente, num momento ou noutro, sobre uma concepção seletiva e normativa da cultura. Não se poderia justificar a educação, fundamentar o currículo, a partir unicamente de conceito sociológico ou etnológico de cultura, já que este conceito não pode fornecer critérios de 
escolha, ele não permite preferir, discriminar, enquanto que toda educação e todo ensino repousam precisamente sobre um princípio de preferência e de discriminação (FORQUIN, 1993: 168).

Para Osborne (2003), compreender o conhecimento científico como uma construção social e cultural, locada em seu tempo, é um dos objetivos para uma educação do séc. XXI. Ele lembra que

O desenvolvimento de uma relação de confiança não depende do conhecimento de um conteúdo, que é esquecido rapidamente quando se sai da escola, mais sim abrir a "caixa preta" da ciência para que os alunos possam entender o que é fazer ciência, como ela se auto-regula e por que razões se pode confiar nela - reorientando o currículo do conteúdo para a prática. Uma educação desse tipo beneficiaria não só o futuro cidadão leigo, mas também o futuro cientista (OSBORNE, 2003).

É partindo desse contexto que se propõe, nesse trabalho, uma reflexão acerca do papel de visitas a laboratórios de pesquisa, em que se buscam, no diálogo com a escola, espaços de articulação para promover a educação científica de estudantes e o público em geral. Essa perspectiva permitiria contemplar o conhecimento da ciência de forma mais global, procurando espaços de atuação com o intuito de inserir novas situações não vivenciadas no cotidiano escolar e, consequentemente, ampliar seu saber sobre essa ciência.

A partir das ideias acima, esse trabalho se reconhece como um estudo de caso, com dupla abordagem, teórica e analítica. Assim, pretende-se refletir e analisar as propostas de divulgação desenvolvidas pelo Laboratório Aberto de Física Nuclear que abriga o acelerador Pelletron, do Instituto de Física da USP.

Para tal, investigam-se as possíveis contribuições da área de pesquisa em ensino de ciências, reconhecendo, em primeiro lugar, o Laboratório como um espaço de ensino não formal, mas, ao mesmo tempo, dotado de importantes especificidades. Assim, são sistematizados alguns resultados de pesquisas sobre esses espaços, de forma a contribuir para caracterizar tanto suas potencialidades como suas limitações. Tais indicações perpassam em reconhecer elementos para 
subsidiar o entendimento dos laboratórios como espaços educacionais; enfatizando singularidades que fazem desses ambientes, lugares capazes de abranger discussões sobre ciência.

Além disso, são também consideradas as possíveis contribuições de trabalhos relacionados tanto à alfabetização científica como ao campo de pesquisas de estudos sobre ciência-tecnologia-sociedade (CTS), no sentido também de ampliar esse universo das possibilidades. Com isso busca-se trazer uma dimensão reflexiva e elementos para compreender como as intervenções de divulgação no laboratório podem ser direcionadas para a compreensão dos objetivos que se quer almejar ao se introduzir estratégias educacionais nesses espaços. Como resultado dessas reflexões, espera-se construir uma sistematização dos vários aspectos e dimensões que podem, potencialmente, orientar as atividades de divulgação em laboratórios científicos.

A sistematização desejada e descrita acima, no entanto, será construída e reconstruída, também, no confronto com a análise das atividades desenvolvidas especificamente no acelerador Pelletron, nos últimos anos. Para isso, além da caracterização do objeto estudado, incluindo os processos técnicos e físicos que envolvem o funcionamento do laboratório, serão apresentadas e analisadas diferentes amostragens de dados obtidas ao longo das atividades desenvolvidas nas intervenções realizadas no acelerador, como: entrevistas, materiais produzidos, relatórios de visitas e atividades.

Assim, traremos no capítulo 1 uma apresentação do acelerador de partículas Pelletron, do IFUSP, entendido como o objeto sobre o qual se desenvolvem as discussões, criando um espaço para contextualizar, de forma mais concreta, as reflexões que serão feitas a seguir. Nessa perspectiva, trataremos de uma descrição inicial do laboratório como objeto, ainda que outra descrição possa vir a fazer parte dos resultados a serem perseguidos, como fruto das reflexões a serem desenvolvidas.

No capítulo 2, trataremos das reflexões sobre os espaços não formais de ensino, onde apresentaremos uma breve discussão sobre esse conceito no campo da educação, discutindo as intenções dos museus científicos como ambientes que 
propiciem a aprendizagem científica. Nesse caso, trazemos discussões sobre a natureza do aprendizado nesse âmbito, assim como abordamos os saberes necessários para que tais aprendizagens ocorram, através do papel das possíveis mediações. Esse capítulo buscou trazer indícios das especificidades do laboratório científico como ambiente educacional e caracterizando-o como mais uma possibilidade de promover a formação científica dos cidadãos.

No capítulo 3, buscamos discutir as concepções dos laboratórios científicos a partir das ideias provindas do campo da sociologia da ciência e como o tema é inserido no campo de educação. Esse reconhecimento das diversas formas de compreender esses espaços ajudou a situar o acelerador Pelletron dentro do campo de pesquisa do ensino de ciências, trazendo subsídios para compreender esses espaços de produção da ciência como ambientes capazes de promover a educação científica.

O capítulo 4 procurou apresentar algumas ideias da Alfabetização Científica e do movimento CTS, buscando uma interlocução com esses estudos teóricos e para subsidiar a análise dos dados. Esse debate trouxe algumas dimensões de ampliação dos saberes envolvidos, a serem contemplados, resultando na construção das categorias que indicam as dimensões pelas quais o material disponível poderá ser analisado. .

A metodologia de pesquisa é abordada no capítulo 5, onde procuramos discutir alguns aspectos de sua inserção no campo da pesquisa social, trazendo em paralelo uma reflexão acerca de problemas que são intrínsecos à coleta de dados e consequentemente, a inferências relacionadas ao material analisado. Esse capítulo também discute as estratégias utilizadas nesse trabalho, buscando trazer algumas definições acerca dos tipos de coleta e suas especificidades.

O capítulo 6 trata da apresentação dos dados e o contexto de sua coleta, trazendo uma seleção de falas e trechos do material a ser analisado, buscando caracterizar as singularidades dos diversos grupos pesquisados. Propomos nesse momento abranger, nas discussões, o material que é apresentado aos visitantes, alguns elementos da forma como as visitas compreendidas pelos alunos e 
professores em suas visitas, além da fala dos pesquisadores, acerca de suas próprias perspectivas sobre essas atividades, entendidas como de divulgação.

No capítulo 7 analisamos esse material em uma matriz de análise, construída a partir das reflexões apresentadas ao final do capítulo 4, buscando caracterizar as categorias que possibilitaram iluminar as discussões seguintes. Assim, apresentamos uma breve reflexão e inferências acerca dos dados, trazendo falas e trechos de materiais significativos para ilustrar as perspectivas propostas.

Nas conclusões, buscamos trazer uma reflexão sobre o trabalho apresentado, articulando as ideias sobre a pesquisa em ensino de ciências e os dados coletados. Procuramos, nesse momento, apresentar um panorama mais geral do que foi observado, tomando esses elementos como subsídios para discutir as diversas possibilidades de atuação nos laboratórios científicos, caracterizando as potencialidades e limitações associadas à promoção da educação científica nesses espaços. 


\section{Capítulo 1}

\section{O acelerador de partículas Pelletron}

\&u nĩ̄o escrevo em português.

\&screvo eu mesmo

ornando Dessoa

Nesse capítulo se busca apresentar o acelerador de partículas Pelletron com o intuito de caracterizar os assuntos abordados nas visitas ao laboratório. Também é proposto um aprofundamento sobre determinados temas, ao longo do texto, possibilitando reconhecer potencialidades que podem ser inseridas nas diversas abordagens possíveis nesse espaço de produção científica.

Tal perspectiva, de atribuir diversas dimensões de leitura sobre o laboratório estudado, remeteu às muitas dificuldades associadas aos enfoques e aprofundamentos, que ao longo do processo, se mostraram complexas, tanto do ponto de vista da compreensão dos conceitos físicos envolvidos como nas formas de abordagens que podem ser direcionadas para os diferentes perfis de visitantes.

Como forma a facilitar a apresentação do Pelletron, procuramos enfatizar a escrita sobre ele em dois contextos: uma primeira opção foi apresentá-lo pelo ponto de vista das visitas ao laboratório, ou seja, trazendo os assuntos discutidos pelos cientistas nos andares apresentados por eles e uma segunda opção, que aparece em paralelo à apresentação das visitas, são as inferências sobre os possíveis temas que podem ser inseridos conforme o aprofundamento necessário em consonância aos diferentes públicos.

Nas duas seções seguintes apresentamos, de forma sucinta, as pesquisas que são desenvolvidas no acelerador Pelletron e o campo institucional do qual ele faz parte. Assim, procuraremos discutir as diversas sub-áreas da física nuclear em que estão inseridos os grupos de pesquisa e como são divididos os afazeres do laboratório conforme as diferentes tarefas atribuídas aos indivíduos que ali trabalham. 


\subsection{Problematização acerca dos aceleradores de partículas}

As visitas ao acelerador de partículas Pelletron, desenvolvidas para o público em geral, foram reformuladas constantemente ao longo desses últimos sete anos, sendo incorporados e retirados diversos conceitos, aprofundamentos, figuras e animações que, através das experiências com os visitantes, se mostraram desnecessários, motivos de confusões e muito complexos para uma compreensão geral.

No entanto, um tema que sempre se mostrou fundamental para as apresentações que antecedem a visita aos andares, foi o de problematizar o sentido de se construir laboratórios como o acelerador Pelletron. Para que tal dimensão de discussão fosse introduzida ao público, foi proposta, como parte das atividades, incluir esses questionamentos na apresentação multimídia. Dessa reflexão, foi inserida a ideia do átomo, com a pergunta: Do que são feitas todas as coisas?

Em seguida, é proposta, como um experimento de pensamento, a ideia de compreender até que ponto se consegue "dividir" qualquer objeto (pedaço de papel, madeira, pedra) e, dessa curiosidade humana, discutir como a Teoria Atômica se construiu como ramo dos estudos científicos (CARUSO \& OGURI, 2006).

A pergunta seguinte da apresentação, que emerge desse exercício intelectual, é compreender como é possível se construir uma imagem de algo que não é possível observar diretamente, como os átomos. Aquilo que é uma representação do átomo, seja o modelo planetário do Bohr ou as representações das probabilidades de Schrödinger, é construída através de inferências experimentais.

Assim, essas dimensões do conhecimento sobre a matéria foram inseridas nessas apresentações, procurando trazer aos visitantes a compreensão da dificuldade de se construir uma teoria e um entendimento sobre algo incapaz de ser visto a olho nu. Enfatiza-se que as respostas a essas questões, no entanto, são produtos de um processo em construção, que são produzidas através do entendimento da "destruição" desse átomo e em alguns casos, na "destruição" de seu núcleo. Em suma, as discussões caminham para aquilo que se faz dentro do 
laboratório, onde procuramos representar um ambiente cuja função é criar fenômenos difíceis de serem observados diretamente na natureza; para, então, a partir do resultado dessas observações experimentais, compreender de forma mais detalhada, o que ocorre nessas condições muito específicas.

Essa é uma possível reprodução dos fenômenos construídos nos aceleradores de partículas que, como objetivo central, procura colidir um feixe de íons com um alvo para que, com essa interação, sejam "destruídos". O que os físicos fazem com os resultados desse processo, como em um jogo de quebracabeça, é, a partir das peças obtidas após a colisão, buscar uma reconstrução do que seriam as condições em que as interações ocorreram. Pretende-se conseguir chegar a um "desenho" mais próximo possível daquilo que corresponde aos estudos científicos (teóricos ou experimentais).

A interação eletromagnética provoca a "destruição" desses íons implica em conseguir vencer a repulsão entre os núcleos e aproximar um do outro de forma que, através da interação entre nucleons (prótons e nêutrons), chamada de força forte, consiga-se desestabilizar o núcleo atômico. É o produto dessa interação que gera os resultados a serem analisados pelos cientistas.

Em suma, a partir desses questionamentos, procuramos apresentar aos visitantes a necessidade de se produzir os grandes experimentos. Esses experimentos requerem, portanto, aparatos onde seja possível promover a colisão entre íons, a energias que superem essa reulsão entre os núcleos. Como altas energias correspondem a altas velocidades no momento da colisão, os íons precisam ser acelerados, fazendo com que essas máquinas sejam conhecidas como aceleradores.

Procuramos olhar para a construção dessas máquinas e a partir delas, compreender onde o acelerador Pelletron se situa. Assim, a relação entre o muito grande e o invisível torna a ciência dos aceleradores capaz de trazer discussões mais amplas sobre o campo das investigações, as dimensões sociais e o trabalho coletivo. Essas questões perpassam a própria história da construção dessas máquinas, desde o desenvolvimento de J. Crockcroft e E.T.S. Walton, em 1931, na construção de aceleradores que usavam descargas elétricas para produzirem 
voltagens suficientemente grandes para se acelerar prótons $\left({ }_{1} \mathrm{H}^{1}\right)$ (feixe de íons) e os colidiam a outros átomos. E é nessa série de desenvolvimento que se chegou até o grande experimento LHC (Larger Hadron Collider) do CERN (Organização de Pesquisas Nucleares da Europa), que promove a aceleração de prótons e íons, através de campos elétricos e magnéticos, colidindo-os com outros prótons e íons. O que esses experimentos possuem em comum é a procura por questões primordiais, cuja finalidade é a produção de conhecimento científico (SESSLER \& WILSON, 2007).

Todas as melhorias, que acarretaram em diversos tipos de aceleradores como os eletrostáticos, lineares, cíclotrons, sincrocíclotron, etc, de certa forma, estão relacionadas com as dimensões conceituais das pesquisas e a produção aplicada desses conhecimentos apareceu a posteriori desse processo.

Os aceleradores eletrostáticos Van de Graaff surgiram como alternativa às técnicas de Crockcroff e Walton. O princípio de funcionamento dessas máquinas de 2 metros de altura é transportar cargas através de correias (silk belts) para uma esfera metálica no ponto mais alto, gerando o acúmulo de cargas e, consequentemente, uma produção de campo elétrico capaz de acelerar os íons.

Para que a "viagem" dos íons sofresse uma ação mais prolongada do campo elétrico, W.H. Bennett, em 1950, introduziu o processo de stripping. Anteriormente à utilização dessa técnica, os íons podiam ser acelerados apenas do terminal, onde as cargas foram acumuladas, ao terra. A técnica de stripping consiste em se produzir íons negativos, acelerá-los e depois se arrancar elétrons dos íons ao fazê-lo atravessar uma fina folha de algum material como o carbono. Com isso os íons podem ser acelerados duas vezes com a tensão do terminal. Se esse processo ocorrer próximo ao terminal, os íons podem ser acelerados tanto se aproximando do terminal como se afastando dele.

A fase seguinte no desenvolvimento dos aceleradores foi o cíclotron, cuja técnica de Ernest Orlando Lawrence, propunha uma aceleração combinada de campos magnéticos e elétricos, onde as partículas eram aceleradas em movimento circular. Enquanto os campos elétricos tinham a mesma finalidade dos aceleradores eletrostáticos, o campo magnético mantinha o movimento circular das partículas. 
Esse tipo de máquina tinha a vantagem de acelerar os íons diversas vezes, pois a cada passagem pelas placas paralelas onde o campo elétrico é gerado, o feixe aumenta sua energia.

Em suma, o desenvolvimento dessas máquinas exigiu altos investimentos, que, em grande parte, permitiram um aprofundamento do conhecimento sobre a matéria. O acelerador tipo síncrotron LHC (Larger Hadron Collider) atualmente pode ser considerado um dos experimentos mais caros já produzidos pelo homem.

A presença do tema na sociedade renova a expectativa de que o conhecimento científico não pode ser deixado em segundo plano e sua dimensão conceitual se mostra necessária para a compreensão das decisões de diversas esferas sociais sobre ele. Nesse sentido, trazer essas discussões para as visitas ao laboratório possibilitou ao longo desses anos reconhecer a importância da problematização desses temas em diálogo com o público geral.

\subsection{O funcionamento do acelerador Pelletron: estrutura geral e o local}

Conhecer o acelerador Pelletron causa a impressão de espanto diante do tamanho da máquina instalada em oito andares. Geralmente, os visitantes que passaram por esse complexo de instrumentos, técnicos, pesquisadores e secretárias, comentam que associam seu funcionamento a um local que não seria diferente de uma empresa privada. $\mathrm{Na}$ medida em que ocorre a interação com os cientistas e técnicos, os diálogos ao longo da visita e o entendimento do processo técnico-científico, algumas dessas correlações acabam por serem abandonadas. Isso ocorre devido ao que consideramos o teor do produto dessa "empresa" e a intenção das pessoas que ali trabalham.

A partir dessas interações, que, para nós, mais do que olhar para o conhecimento científico representam as escolhas ao se apresentar o funcionamento do acelerador, procuramos pautar as explicações nas dinâmicas das relações entre o conhecimento técnico e o científico, entre o conhecimento geral e o específico. Em alguns casos, a reflexão sobre o que pode ser apresentado para visitantes nesse laboratório cria a necessidade de situar o tipo de máquina, sua função em relação a outros tipos de aceleradores, o que o diferencia ante as novas tecnologias, etc. 
Quando, nesse processo, se pensa em diversos níveis de aprofundamento, alguns temas se tornam essenciais enquanto outros, nem tanto. Esse processo traz, para aqueles que pensam tais atividades, uma reflexão sobre os temas e conteúdos físicos que podem ser escolhidos. De certa forma, aquilo que é considerado, por uns, como uma opção não relevante na abordagem das visitas, pode ser considerado essencial para outros. $O$ que, no entanto, nos indica quais as escolhas mais adequadas é, em grande parte, a própria interação com os visitantes. Através do diálogo dos sujeitos: uns com os outros, conosco e com os cientistas, os visitantes ajudam a tornar essas dimensões mais claras.

A primeira das questões que emergiram no processo desse trabalho é a necessidade de apresentar o laboratório Pelletron em um contexto geral. Após a exibição, que consideramos mais conceitual-científica, da apresentação multimídia, é importante para o visitante compreender quais os andares que serão visitados. Esse "olhar para o todo" permite que o público possa criar uma ideia mais ampla do acelerador. Mesmo que não se tenha, nesse momento, nenhuma discussão aprofundada sobre a parte técnica, a visão do laboratório e a estrutura por onde passam os íons, é fundamental para o visitante compreender porque é necessário esse tipo de condição estrutural para o Pelletron. Ou seja, aspectos como a necessidade de mudar a direção do feixe no $8^{\circ}$ andar e no andar térreo ou a extensão do tanque acelerador.

Assim, a visita aos andares, geralmente se inicia com uma breve explicação do acelerador de forma mais ampla. Essa apresentação é feita com a ajuda da planta do laboratório Pelletron (Figura 1) e, de forma geral, busca contextualizar a estrutura, do ponto de vista da construção da máquina e do processo de aceleração. 


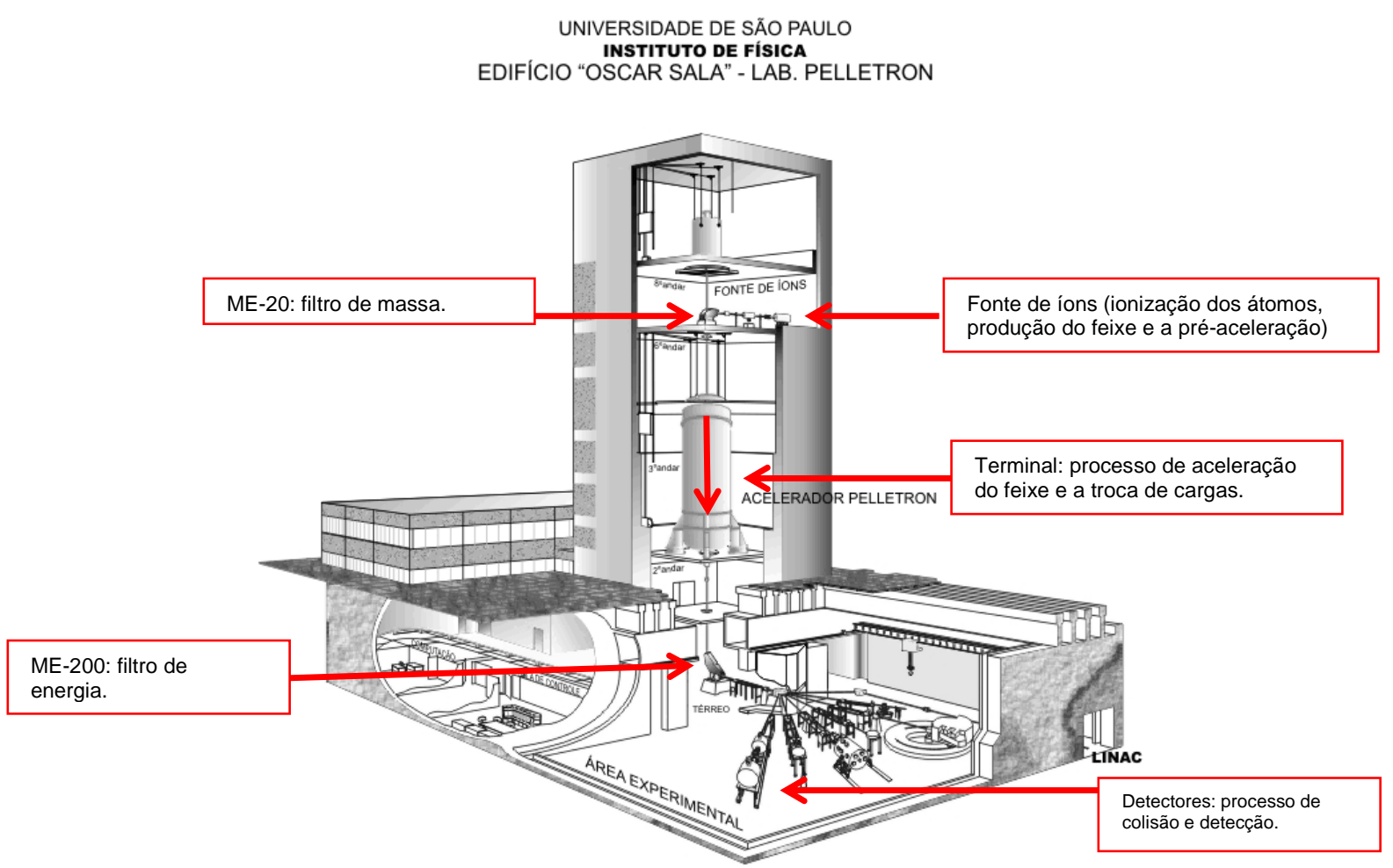

Figura 1.1: Esquema Estrutural do Acelerador de Partículas Pelletron

A apresentação sobre o funcionamento do acelerador não se modifica muito em relação ao tipo de público, pois tem a função de mostrar o todo. Inicia-se essa discussão com a problematização sobre como se acelerar os átomos. Para isso é preciso que os átomos sejam ionizados, ou seja, possam ganhar ou perder elétrons, para conseguir "sentir" o campo elétrico no terminal e, assim, aumentar sua velocidade. O termo terminal ou tanque de aceleração, apesar de técnico, não se torna um problema para seu entendimento, principalmente para alunos do ensino médio, pois é exemplificado no desenho. No entanto, a ideia de feixe, como um conjunto de íons, precisa ser caracterizada de forma mais clara, pois é o termo que acompanhará toda a visita, assim como será seu trajeto que guiará os visitantes. Neste sentido, se discute a princípio a emissão de íons em direções aleatórias e que há a necessidade de deixá-los organizados, para que possam "viajar" de forma conjunta na canalização ou tubos, podendo ser compreendidos esses tubos como túneis que conduzem esses átomos.

Assim, para iniciar todo o processo, são colocados na fonte de íons ( $8^{\circ}$ andar) os elementos químicos que constituirão o feixe e, em um processo de aquisição de elétrons a partir da interação com átomos de césio que se encontram em forma de 
gás, se ionizam. O feixe sofre sua primeira aceleração através da diferença de potencial nos tubos que se encontram na fonte de íons, iniciando assim a trajetória. Logo após a fonte, os íons do feixe são concentrados no eixo da canalização através de campos elétricos (tripleto de quadrupolos eletrostáticos) para que possam ser propagados ao longo de todo o acelerador. Ainda no $8^{\circ}$ andar, se encontra o ME-20, que é um eletroímã que tem a finalidade de manter no feixe apenas os íons com a massa desejada.

No intervalo entre o 6 andar até o térreo, é explicado que o feixe passa pelo processo de maior aceleração, onde um campo elétrico induz o aumento da velocidade dos íons na canalização. Isso ocorre em um ambiente de baixa pressão, ou seja, existem bombas que são capazes de retirar quase todo o ar de dentro de toda a canalização do acelerador. No entanto, no meio do terminal, o feixe precisa mudar o sinal da sua ionização, pois o campo elétrico inverte de sentido e irá desacelerar cargas negativas e acelerar cargas positivas. Portanto, os íons que compõem o feixe precisam perder elétrons para continuarem a ser acelerados. Esse processo é chamado de stripping e se dá quando o feixe passa por uma fina folha de carbono, perdendo elétrons para o material.

Também é discutido que, no fim desse trajeto, o feixe encontra outro eletroímã, ME-200, que mudará novamente o caminho do feixe através da força magnética. Esse aparato possui a finalidade de manter no feixe apenas íons que apresentam um determinado estado de carga, e consequentemente energia, escolhido. Depois dessa seleção, um último eletroimã, o Switch Magnet, direciona o feixe para a canalização na sala experimental onde deverá ocorrer o choque com o alvo, onde os processos de colisão geram produtos (partículas ou radiação) a serem medidos e analisados. $O$ processo de decodificação das informações sobre essas partículas e radiações em dados a serem analisados pelos pesquisadores é feito por detectores e computadores.

Esse momento de interação com o público expõe, de forma simplificada, o processo que será conhecido, em partes, nos andares visitados. Ao longo dos anos de visitas ao Pelletron, essa prática se mostrou importante para dar unidade ao conhecimento que procuramos estruturar na visita, possibilitando que cada ponto 
específico apresentado ao longo do laboratório fosse introduzido na estrutura geral e construindo um saber sobre o acelerador muito particular de cada visitante.

A visita aos andares também se dá em diferentes níveis de explicação, que são geralmente aprofundados através do diálogo com os cientistas. Nessas interações as questões técnicas são geralmente mais discutidas, dando maior ênfase aos conceitos físicos relacionados aos processos de aceleração.

\subsubsection{Como se produzem íons no Pelletron}

No oitavo andar, os visitantes iniciam a jornada junto com os íons até o processo de colisão com os alvos. Para o público geral, apesar de não ser abordado nas visitas, pode ser apresentado o processo de produção do feixe no acelerador, que começa mesmo antes da inserção do elemento químico de interesse na fonte de íons. Para que o feixe seja produzido, é discutida a necessidade de um profissional (químico) que produza um pequeno cilindro (cadinho ou pastilha) com o material escolhido pelo grupo de pesquisa. Esses cadinhos são levados à fonte de íons MC-SNICS (Multicathode Source of Negative Ions by Cesium Sputtering ) do Pelletron. Uma vez colocados os cadinhos na fonte de íons, inicia-se o processo de ionização dos átomos presentes nessa amostra de material através da evaporação do Césio que, ao atingir os elementos inseridos na pastilha, provoca a "expulsão" do material, que em contato com o gás de Césio, é ionizado negativamente (ganho de elétrons), passando a sentir o efeito do campo elétrico aplicado na fonte de íons.

Nas visitas é comentado que devido ao acoplamento de diversos cadinhos na fonte de íons, pode ser trocado o elemento químico que compõe o feixe acelerado com uma pequena intervenção do técnico responsável. Assim, caso seja necessário mudar um feixe para que outro grupo utilize a máquina, não é necessário que a instrumentação seja totalmente desligada.

Algumas dessas discussões do fazer científico foram sendo incorporadas nas discussões com estudantes do ensino médio, na medida em que, para esses jovens, muitos dos elementos descritos passavam a ter pouco significado, pois alguns conceitos científicos são fundamentais para a compreensão do funcionamento do acelerador e de seu objetivo, como energia, campos elétricos e magnéticos, 
ionização, etc. Alguns temas, ainda não incorporados nas visitas, mas importantes, são as unidades físicas que aparecem nessas discussões para a compreensão das grandezas que estão envolvidas no processo. Isso implica em discutir o sentido de dizer que o feixe sai para o tubo pré-acelerador com uma energia $15 \mathrm{keV}$ (ABREU, 2004). Para o estudante, tal número não tem significado físico. Nesse sentido, salientar as relações entre entrar com $15 \mathrm{keV}$ e sair do tubo pré-acelerador com 95 $\mathrm{keV}$, pode não ser uma representação simples para os visitantes.

Ainda no oitavo andar, aparece outro conceito importante: a ação de campos elétricos e magnéticos, que é comentado nas visitas. Esses campos que irão induzir as mudanças de trajetória do feixe e que promoverão a colimação do mesmo, ou seja, induzi-lo a permanecer coeso no eixo da canalização através de um tripleto do quadrupolos eletrostáticos. O conceito também aparece novamente no processo de mudança de direção do feixe pelo eletroímã ME-20, que através de uma força magnética deflete o feixe em $90^{\circ}$ para ser injetado no terminal vertical, enquanto a fonte foi montada horizontalmente (VILLARI, 1982; CARLIN, 1983).

Para um aprofundamento, a mesma explicação pode ser direcionada para uma linguagem mais acadêmica voltada a estudantes de graduação ou professores de Física na escola básica. Assim, geralmente tais apresentações se iniciam com a discussão sobre a produção do feixe, onde o elemento que irá produzi-lo no acelerador é inicialmente compactado em um cadinho formando uma pastilha (cátodo) que pode ser montada em um carrossel com até 32 cátodos de elementos químicos diferentes, permitindo que sejam modificados os feixes sem a necessidade de interrupção da operação. Esse carrossel ao ser acoplado na fonte de íons MCSNICS inicia o processo de ionização através da evaporação do césio, que expulsa os elementos inseridos na fonte e os ioniza negativamente ao interagirem com o gás formado, fazendo-os sentir o efeito do campo elétrico aplicado na fonte de íons. A energia do feixe nesse momento fica em torno de $15 \mathrm{keV}$ e é inserido no tubo de pré-aceleração (ABREU, 2004).

O tubo de pré-aceleração possui um potencial de $-80 \mathrm{kV}$, e o formato de anéis acoplados permite uma diferença de potencial que consegue acelerar o feixe até, aproximadamente, $95 \mathrm{keV}$ de energia, preparando-o para a introdução no tubo 
acelerador. O eletroímã ME-20 (20 é máximo valor de $M E / Z^{2}$ ) deflete o feixe em $90^{\circ}$ para ser injetado no acelerador Pelletron que é vertical enquanto a fonte foi montada horizontalmente (VILLARI, 1982; CARLIN, 1983).

Esse tipo de escolha, dependente do público, permite que as preocupações com os termos sejam minimizadas para dar ênfase a questões voltadas aos processos técnicos envolvidos, por exemplo. Deve-se, no entanto, compreender que essa escolha não se associa diretamente aos ciclos de escolarização, pois na própria constituição do ensino médio há níveis de aprofundamento diferente. Enquanto alguns estudantes voltam seus estudos para o ensino médio geral, outros aprofundam determinados conhecimentos em áreas técnicas como eletrônica e mecânica. Para esses alunos, existem outras demandas para as visitas, assim como para alunos de graduação de cursos voltados para as ciências humanas.

\subsubsection{Como se aceleram feixes de íons.}

A segunda parte da máquina a ser conhecida é do quinto ao terceiro andares, onde os visitantes podem observar o tanque de aceleração. Nesse momento é discutido com os estudantes o processo que, efetivamente, aumenta a velocidade dos íons. Aqui a intenção é que os alunos compreendam o processo que ocorre com o feixe ionizado com excesso de elétrons na região do tanque do acelerador após sofrerem uma pequena aceleração inicial na fonte de íons. Nesse momento, ocorre a função mais importante do acelerador, que é o aumento da velocidade dos íons.

Para que isso ocorra, é discutida a existência no terminal de uma fonte de tensão positiva, que é carregada através de um processo de indução de cargas gerado por duas correias formadas por diversos pellets (cilindros de metal) intercalados com tubos de teflon. Geralmente, são apresentados para os estudantes os pellets, pois o tanque não pode ser visitado por dentro. É explicado que essas cargas viajam através dos pellets das correias até o terminal e, ao chegarem, esses pellets induzem cargas positivas em um capacitor, gerando um campo elétrico que acelera o feixe ionizado negativamente. Esse tipo de processo, em geral, tem relação mais próxima com alguns conteúdos aprendidos na escola básica. 
Algumas condições técnicas também são comentadas, como a importância de que o terminal esteja inserido em um ambiente protegido com um gás isolante em alta pressão, para evitar a ocorrência de descargas elétricas devido às altas tensões criadas no terminal, o que prejudicaria o funcionamento da máquina, além de criar uma situação de risco à segurança dos técnicos e pesquisadores que trabalham no acelerador. Essas discussões, no entanto, são mais produtivas para visitantes mais avançados do ponto de vista dos conteúdos.

Seguindo as discussões sobre a aceleração, no decorrer dos anos, alguns debates se mostraram inesperadamente interessantes para alunos da escola básica. Dentre eles, o processo conhecido como stripping é muito proveitoso, pois evoca alguns conceitos de campo elétrico e eletrização, que geralmente já foram discutidos em sala de aula e possibilitam maior interação dos estudantes com o cientista. $O$ processo em si é necessário devido ao fato do campo elétrico no terminal mudar de sentido, o que implicaria em promover uma desaceleração no feixe, diminuindo ao invés de aumentar sua velocidade. Quando os alunos compreendem o problema, é apresentada a solução, engenhosa pela simplicidade, que implica na existência, no meio do tanque, de um trocador de carga. Quando o feixe passa por essa fina folha de carbono, em um processo de interação entre cargas, alguns íons do feixe acabam por perder seus elétrons para os átomos de carbono, ficando ionizados positivamente. Assim, podem novamente ser acelerados pelo campo elétrico e continuarem o processo de aumento de velocidade.

Ao término da aceleração na tubulação do terminal, o feixe encontra o eletroímã ME-200 que muda novamente o caminho do feixe através de um campo magnético, como o processo já discutido no oitavo andar. O que diferencia o ME-200 é o seu propósito de selecionar a energia do feixe. Essa seleção é feita através da relação entre massa $(M)$, estado de carga $(Z)$ e energia $(E)$. Como os termos geralmente empregados nesse processo são complexos, eles são comentados, mas não aprofundados com alunos do ensino médio.

Quando tal apresentação se remete a um público focado em interesses técnicos ou científicos, é possível construir uma ideia mais direta sobre o funcionamento e o papel do tanque onde os íons são acelerados pelo terminal 
positivo. O processo de stripping pode ser compreendido como a passagem do feixe por uma fina folha de carbono disposta no interior do terminal para que os íons que o compõem percam elétrons (processo de stripping) e continuem o processo de aceleração.

Ao final do processo de aceleração do feixe, a energia do íon (E) no estado de carga Z pode ser expressa a partir da equação 3 (VILLARI, 1982).

$$
\mathrm{E}=\left|e \mathrm{~V}_{\text {inj }}\right|+(\mathrm{Z}+1) e \mathrm{~V}_{\text {term }}(\text { Equação 3) }
$$

Onde:

$\mathrm{V}_{i n j}=\mathrm{a}$ soma do potencial de extração do feixe no interior da fonte de íons com a tensão aplicada no tubo pré-acelerador

e = a carga eletrônica

$\mathrm{V}_{\text {term }}=$ a tensão do terminal

Finalmente, as partículas são defletidas em 90ำ pelo eletroímã ME-200, que seleciona a energia do feixe. Essa seleção é feita através da relação entre massa $(M)$, estado de carga $(Z)$ e energia $(E)$. Então, o feixe passa por um imã seletor que o desvia para uma das seis canalizações desejadas.

Essa forma de apresentar o terminal também indica que outros termos podem ser ainda mais aprofundados, sendo caracterizados como níveis mais próximos daqueles que os cientistas do laboratório e os técnicos se encontram.

\subsubsection{Colidindo o feixe com o alvo}

A última parte da visita compreende a sala de controle e a sala experimental. $\mathrm{Na}$ sala experimental são apresentadas as câmaras onde ocorrem as colisões entre o feixe e o alvo. É explicado que primeiro o feixe passa pelo Switch Magnet, que o direciona para a canalização desejada, onde em sua extremidade se encontra a câmara de espalhamento com os detectores. Assim, ao término desse caminho, existem os detectores cuja função é realizar as medidas dos produtos da reação entre o feixe e o alvo, todos localizados no interior da câmara. 
Pode-se discutir com os estudantes que a produção do alvo com o qual o feixe irá interagir é elaborada pelos técnicos do Laboratório de Alvos, onde são feitas finíssimas folhas de determinados elementos químicos, selecionados pelos grupos de pesquisadores, e que serão posicionados no centro da câmara de espalhamento. Os alvos são produzidos geralmente a partir de um processo de evaporação do material em uma folha de carbono. Esse processo exige espessuras bem definidas e tão pequenas que são quase transparentes, da ordem de micrômetros. A escolha, por abrir esses espaços de discussão sobre os diversos tipos de profissionais envolvidos no experimento, traz importantes indícios para os estudantes, da complexidade do fazer científico nesses espaços. A discussão prossegue com o processo de colisão com os alvos, onde os detectores fazem o papel de 'capturar' as informações das partículas espalhadas e enviá-las para a sala de controle. Nessa sala, computadores e controladores fazem, juntos, o papel de monitorar todo o experimento, desde o oitavo andar até a sala experimental.

A finalização da visita é feita na sala de controle, onde os estudantes podem discutir com o cientista sobre os produtos desse processo. Sem roteiro pré-definido, esse momento remete a questões mais amplas dos estudantes, como os órgãos que controlam a instituição, a divulgação dos estudos através de artigos científicos, as formas de se angariar recursos financeiros para projetos, se existem comissões de ética, etc.

Há a possibilidade de aprofundamento do tema, acrescentando explicações sobre o papel dos detectores que farão as medidas dos produtos da reação entre o feixe e o alvo. Assim, após o processo de aceleração do feixe e a colisão com os alvos, os detectores fazem o papel de 'capturar' a informação proveniente desta colisão.

Um exemplo de detector de partículas corresponde à câmara de ionização. Esse tipo de detector pode ser composto por duas placas paralelas distantes poucos milímetros, imersas em gás e com uma diferença de potencial aplicada. Ao penetrarem o interior das placas, as partículas produzem pares elétron-íons no gás e, assim, quando a razão entre o campo elétrico e a pressão do gás for otimizada, ocorrerá uma avalanche onde os elétrons produzidos contribuem para a captação do 
sinal a ser estudado (MEDINA, 1988). Os conversores conectados aos detectores fazem a conversão analógico-digital dos sinais elétricos para serem enviados aos computadores da sala de controle, onde são posteriormente analisados pelos pesquisadores.

\subsection{O campo científico do acelerador Pelletron (trabalhos desenvolvidos)}

Os grupos de pesquisa do acelerador Pelletron não são mencionados diretamente durante as visitas. No entanto, as questões que permeiam as pesquisas e suas aplicações são discutidas em diversos momentos. As escolhas de determinados conteúdos em prol de outros foram feitas em parceria com alguns professores, que sugeriram temas e formas de abordagem que pudessem, ao longo das visitas, serem mais bem explorados.

Os grupos de pesquisa no Departamento de Física Nuclear são divididos em três grandes áreas: física nuclear experimental, física aplicada e física teórica. Os pesquisadores das duas primeiras áreas possuem, de forma mais direta, trabalhos relacionados ao acelerador Pelletron.

O primeiro grupo, de pesquisadores em física nuclear experimental, se divide em outros seis subgrupos, que possuem em comum o objetivo de compreender e ampliar os conhecimentos sobre o núcleo atômico. Esses grupos são:

- Espectroscopia de raios gama (Gama)

- Reações com íons pesados (GRIP)

- Dinâmica de reações nucleares com íons pesado-leves (IPL)

- Reações diretas e de núcleos exóticos (Exóticos)

- Fusão de núcleos pesados (FNP)

- Íons pesados relativísticos (IPR)

O segundo grupo, relacionado com a física aplicada, possui três subgrupos, que procuram, através dos estudos interdisciplinares, desenvolver e explorar a aplicabilidade das técnicas criadas para o estudo do núcleo atômico nas mais diversas áreas. Esses subgrupos são:

- Laboratório de dosimetria da radiação (Dosimetria) 
- Laboratório de cristais iônicos, filmes finos e datação (Lacifid)

- Física aplicada com aceleradores (GFAA)

No campo das pesquisas básicas, trabalhos voltados para a compreensão da estrutura dos núcleos e suas interações, são abordados nas visitas, mencionando aspectos conceituais que geraram questionamentos e, consequentemente, 0 desenvolvimento de trabalhos experimentais no laboratório. Esses aspectos contextualizam, de forma mais ampla, os grupos, possibilitando que o público, no geral, compreenda o sentido de se fazer pesquisas que, a priori, não possuem aplicabilidade para a sociedade, mas gerando produtos intelectuais como: artigos, conferências, cursos, etc.

São discutidos com os estudantes da escola básica, na apresentação multimídia, por exemplo, os tipos possíveis de formatos do núcleo atômico, promovendo uma reflexão sobre a ideia errônea do núcleo como uma esfera compactada de prótons e nêutrons. São abordadas as diferentes formas para os núcleos, já encontradas em trabalhos experimentais, e de como estes estudos se relacionam com a ideia de se colidir partículas nesse núcleo, tentando construir uma imagem pictórica através da desestabilização do núcleo. Tal ideia, que provém dos estudos do grupo de Espectroscopia dos raios gama, é simplificada ante os trabalhos desenvolvidos pelos pesquisadores. Os estudos da espectroscopia gama, dentre tantos, tem como um de seus objetivos compreender os estados de momentos angulares elevados do núcleo atômico: altos spins. Esses projetos buscam através do estudo da radiação gama emitida em núcleos excitados, compreender as estruturas nucleares e a configuração de um estado nuclear.

Outra discussão abordada são as reações nucleares, que permitem, através dos estudos experimentais, compreender a dinâmica das estrelas. São apresentadas ao público o processo de fusão nuclear e a produção de energia nesse processo, através da conversão da massa dos núcleos envolvidos em energia, prevista pela equação $E=m c^{2}$. Estudos nessa linha são produzidos pelos pesquisadores dos grupos de Reações com íons pesados, Fusão de núcleos pesados e Dinâmica de reações nucleares com íons pesado-leves. 
A formação e estudo de núcleos exóticos também são discutidos com os estudantes. São apresentadas as diferentes configurações de prótons e nêutrons para formação de um núcleo estável na natureza e a produção de núcleos artificiais no laboratório. O caso exemplo tratado é o do Lítio 10 , que nunca é formado, mas que é possível a formação do Lítio $11\left(\mathrm{Li}^{11}\right)$ que apresenta um par de nêutrons a mais que o núcleo de Lítio 9. Esse tipo de trabalho, desenvolvido pelo grupo de Reações diretas e de núcleos exóticos, usa núcleos que apresentam energias de ligação baixa, para compreender as reações que ocorrem com núcleos instáveis. Esses estudos quando voltados para a Astrofísica Nuclear procuram compreender as reações que envolvem a nucleossíntese nas estrelas.

No campo da pesquisa aplicada, são apresentados diversos trabalhos que envolvem a cooperação interdisciplinar das pesquisas. Esses estudos são apresentados com o intuito de mostrar as diversas formas possíveis de inserção da física dos aceleradores na sociedade. No entanto, suas dimensões de análises, processos e técnicas envolvidas não são discutidas devido a complexidade do tema.

Dentre os trabalhos apresentados estão: a caracterização dos tipos de pigmentos utilizados em obras de arte garantindo sua autenticidade; determinação da composição de materiais arqueológicos que preservam o estado da peça; e a irradiação em materiais biológicos para a compreensão da concentração de determinados elementos. O grupo que possuí trabalhos nessa linha é o de Física aplicada com aceleradores. Os trabalhos desse grupo se direcionam para a compreensão e aprimoramento de técnicas nucleares que possam ser utilizadas nos mais diversos tipos de materiais. A técnica PIXE (Particle Induced X-Ray Emission), utilizada pelo grupo da Física aplicada com aceleradores, é não destrutiva e utiliza os espectros de emissão de radiação das camadas mais internas do átomo ( $\mathrm{K} \mathrm{e} \mathrm{L}$ ) para identificar os elementos que constituem um material.

Esses trabalhos, que são apresentados aos visitantes do laboratório Pelletron, foram incorporados ao longo do tempo com a função de promover reflexões sobre os diversos conhecimentos que estão envolvidos nos experimentos no acelerador.

\subsection{O campo institucional do acelerador Pelletron}


As visitas ao laboratório não apresentam, em geral, informações sobre a estrutura social do Pelletron e como se dão as organizações entre pesquisadores e funcionários. Alguns aspectos pontuais dessas questões, no entanto, algumas vezes emergem na fala dos visitantes, através do diálogo com os cientistas.

Podemos, nesse contexto, compreender a organização do laboratório como ocorrendo em três grupos: pesquisadores, técnicos e administrativo.

O grupo de pesquisadores inclui professores, alunos de pós-graduação, estudantes de iniciação científica, etc. Organizados em grupos, sob a coordenação de um professor, procuram estabelecer os tipos de experimentos e as reações desejadas, para após a coleta de dados, produzirem trabalhos escritos em forma de artigos e apresentações em conferências. Esse tipo de trabalho no laboratório é escrito por um ou dois autores, geralmente orientador e orientando, sendo inseridos outros nomes na lista de autores, conforme a participação desses no experimento citado.

São esses grupos que procuram financiamentos para os projetos estudados, através de submissão de projetos para agências financiadoras. Outra parte do financiamento das pesquisas vem do Instituto de Física, que também disponibiliza os funcionários e técnicos, contratados pela Universidade de São Paulo. Esses pesquisadores também participam de comissões internas que procuram representar o interesse dos diversos grupos e a divisão dos recursos financeiros e de técnicos conforme demanda.

Os técnicos são profissionais de diversos níveis (médio e superior) que trabalham na manutenção da máquina e auxiliam na realização de experimentos. Cada parte do acelerador possui detalhes que somente o conhecimento aprofundado, como dos profissionais que trabalham no acelerador, pode permitir sua efetiva operação. Em trabalhos acadêmicos, artigos e conferências, algumas vezes, esses profissionais são inseridos como co-autores, devido a participação nos experimentos do laboratório.

O grupo administrativo é composto por profissionais que organizam a infraestrutura e as questões burocráticas do departamento. São eles que produzem os 
calendários com os prazos dos grupos para entrega de relatórios, divulgam editais de novos programas de financiamento, organizam as fichas de pontos de funcionários, pesquisadores e bolsistas, etc.

Em números, essa organização possui, atualmente: 45 alunos de iniciação científica, 18 alunos de mestrado, 22 alunos de doutorado, 29 docentes, 41 funcionários e 12 colaboradores e pós-doutorandos ${ }^{1}$.

\footnotetext{
${ }^{1}$ Dados referentes à Dezembro de 2011.
} 


\title{
Capítulo 2
}

\section{Os espaços não formais de ensino e o papel da mediação}

\author{
Sobre a cidade e os campos, os tetos $e$ os trigais \\ Exxercerei a sós a minha estranha esgrima \\ Suscando em cada canto os acasos da rima \\ Tropecando em palavras como nas calgadas \\ Topando imagens desde há muito sonhadas
}

Oharles \$audelaire

De maneira geral, define-se educação formal como uma escolarização baseada em uma grade curricular, sistematizada e organizada (DIB, 1988; CAZELLI \& COIMBRA; 2008). Assim, o papel da educação não-formal é entendido como aquela que ocorre em ambientes fora do espaço formal, e ainda que de alguma maneira sistematizada e organizada, sem obedecer a currículos e metodologias.

Cabe salientar que aquilo que Gaspar (1993) entende como espaço informal, ou seja, lugares onde não há a preocupação com a avaliação, são denominados por Cazelli (1999) como espaços não-formais. Para a autora, a educação não-formal tem uma organização espaço-tempo flexível, que se caracteriza por atividades de cunho coletivo e com conteúdos apresentados de forma sequencial, obedecendo a situações cronológicas diferenciadas e tempo de aprendizagem não fixado a priori, como na educação formal (GOUVÊA et. al.; 2001).

As autoras ainda enfatizam que esses espaços não se confundem com os institutos de pesquisa, quando pensados como centros de investigações, no sentido usual do termo. Assim suas preocupações se direcionam para problemas específicos de pedagogia e, portanto, voltados a uma divulgação correta e inteligível dos saberes neles veiculados (GOUVÊA et. al.; 2001).

Ainda, são muitas as ideias sobre o papel desses espaços não formais na aprendizagem de estudantes da escola básica e, principalmente, no desenvolvimento de sua vida fora dos bancos escolares. Neste sentido, trabalhos sobre a interação centros/museus de ciência e escola básica (GUISASOLA et. al., 
2005; CAZELLI \& COIMBRA, 2008; GOUVÊA et. al., 2001; QUEIROZ, 2010) vêm estudando possibilidades de intervenções e suas muitas propostas de inserção no contexto da escola básica.

Nas próximas seções buscaremos caracterizar o conceito de espaço não formal no campo da educação, trazer uma breve contextualização sobre os museus de ciências e o papel das mediações nesses ambientes.

\subsection{O conceito de espaço não formal de ensino}

Os estudos na educação formal, seja ela científica ou não, sempre foram delimitados por instituições, cuja grade curricular $e$ as bases e diretrizes educacionais permearam as atividades pedagógicas. No entanto, como de fato aconteceu, a educação nunca se limitou ao espaço escolar e os processos de aprendizagem sempre tomaram rumos que nem sempre permearam o contexto educacional e os preâmbulos a ela associados. Assim, não são mais raros questionamentos sobre os diversos ambientes onde sujeitos aprendem conhecimentos extracurriculares e/ou curriculares formando o que hoje reconhecemos como a educação informal e não-formal. Essas proposta, cerceada pelas definições excludentes da educação formal, tentam compreender as diversas estratégias e formatos pelas quais a sociedade se lança para promover outras possibilidades de aprendizagem fora do contexto escolar.

Por este motivo, o ensino não-formal ganhou espaço no debate educacional internacional, mais especificamente nos EUA, em meados dos anos de 1960 e 1970, para contrapor a visão hegemônica de que um sujeito só poderia aprender 0 conhecimento escolar dentro de um espaço formal. No Brasil, os primeiros trabalhos sobre o tema ganharam força a partir dos anos 2000 para discutir, analisar e compreender como atividades geradas por instituições de amparo social, ONGs, projetos educacionais extracurriculares, museus, etc., poderiam influenciar na educação dos jovens estudantes da escola básica (GARCIA, 2009).

No campo de educação em ciências, tentativas de interação escola-museu proporcionaram novas reflexões sobre o papel da educação nos espaços não formais, buscando uma ampliação do impacto social de exposições científicas 
(QUEIROZ, 2010). Para Nascimento (2010), as escolas, ao aproximar os estudantes desses ambientes, esperam que, através dessas interações, promovam-se conhecimentos capazes de desenvolver atitudes cidadãs. Isso supõe a problematização dos usos sociais da memória, das relações e produção de materiais e simbólicas do homem ao longo do tempo, em diferentes sociedades e culturas (NASCIMENTO, 2010: 134).

O primeiro ponto, no entanto, a ser analisado pela educação não formal e informal refere-se ao fato de que ambas sofrem pela sua definição pautada na exclusão, como lembra Gadotti (2005), em relação ao espaço formal. Isso implica que as atividades propostas fora do âmbito escolar seriam uma negação ao ato pedagógico contextualizado pelo ambiente educacional, pautado nas grades curriculares, leis e diretrizes, que delimitam a educação formal. Isso implicaria, para o autor, em compreender os espaços não-formais como uma oposição ao próprio espaço formal, enquanto deveriam ser vistos pela sua especificidade.

Faz coro a este problema Garcia (2009), quando enfatiza que a educação não-formal não teria uma relação direta ou de dependência com a educação formal. Seria, portanto, um acontecimento que busca responder a diferentes preocupações com a formação integral do ser humano, no sentido de considerar contribuições vindas de experiências que não são priorizadas na educação formal (GARCIA, 2009:21).

Para a autora, a compreensão de tal conceito remete à sua utilização e compreensão dentro de um campo conceitual, que pode ser comumente confundido ao utilizarmos parâmetros, objetos e referências que permeiam a educação formal: dessa forma tendemos a compreender a educação não-formal a partir da formal, de uma maneira dependente e irreal (GARCIA, 2009:26). Esse fator aparece no contexto de seu trabalho, que buscou compreender o conceito de educação nãoformal à luz da filosofia de Deleuze ${ }^{2}$, como fundamental para corroborar a ideia da criação do conceito visto como contexto, sendo criado e recriado, sem um consenso ou fim determinado.

\footnotetext{
${ }^{2}$ Filósofo de origem francesa teve seus trabalhos voltados à defesa de uma filosofia como criação de conceitos.
} 
Jaume Trilla (2008), também, lembra que outro discurso bastante recorrente em defesa das questões acerca da educação não-formal nasceu na própria necessidade dos âmbitos educacionais de legitimarem uma ideia ou lema, de uma educação permanente, o que implicaria em outros espaços de atuação da aprendizagem ao longo da vida. Para o autor, isso ocorreria tanto em sua extensão horizontal como institucional, agregando a essa discussão a questão espacial, de onde teria nascido o termo espaço não-formal.

Garcia completa a ideia de Trilla quando enfatiza que

A educação não-formal pode considerar, valorizar e reafirmar a cultura dos indivíduos nela envolvidos, incluindo educadores e educando, fazendo com que a bagagem cultural que cada um traz seja respeitada e esteja presente no decorrer de todos os trabalhos, procurando não somente respeitar e valorizar a realidade de cada um, mas indo além, fazendo com que essa realidade perpasse todas as relações (GARCIA, 2009:53).

Para a autora, a educação não-formal deve ser compreendida como uma educação que se difere da formal pela sua forma de trabalhar e seus espaços diversos. E que não se opõe ou complementa a escola quando deixa de cumprir seus deveres ou realiza precariamente seu papel de transmissão dos conteúdos curriculares. O espaço não-formal, portanto, deve ser encarado como uma maneira distinta de trabalhar a educação e deve ser entendida em seu contexto mais amplo de possibilidades e diversidades de estratégias (GARCIA, 2009).

Para Afonso (1989) a educação não-formal deve ser vista como um tipo de educação que obedece a uma estrutura e uma organização, por vezes diferente da educação formal, que pode ou não levar a uma certificação. No entanto, sua flexibilidade de tempo, local e conteúdos são os principais elementos que o diferenciam das outras formas de educação. Bezerra (2000) resgata a ideia de flexibilidade como uma característica considerada central para a educação nãoformal, tanto no que diz respeito à grande variedade de projetos que se enquadram no conceito, quanto à organização mais aberta e livre que esses projetos possuem. A flexibilidade e a liberdade de ação seriam fatores fundamentais na educação não- 
formal, possibilitando que se trilhem caminhos que a educação formal cercearia (BEZERRA, 2000:10). A autora ainda busca outra vinculação para a compreensão do conceito, através de sua relação com o cotidiano. Defende que uma educação que se paute em uma transformação social precisa compreender o mundo em que os sujeitos estão inseridos e isso remeteria a uma abordagem da educação nãoformal que contemple a realidade de seus indivíduos, retornando à sociedade de forma transformada.

Haim Eshach (2007) argumenta que as melhores distinções acerca do tema não são aquelas associadas ao espaço físico, ou seja, "dentro ou fora da escola" e sim a outros fatores como: motivações, interesses, contexto social e avaliações. Para o autor, a educação informal deve ser compreendida em situações da vida onde a aprendizagem é espontânea, como nos círculos familiares ou de amigos. A educação informal também teria, segundo Esbach, uma distinção relevante que é a ausência de uma figura de autoridade ou um mediador. No entanto, é importante salientar que a instituição familiar não deixa de ser um ambiente educacional, mas que evoca um entendimento bastante assistemático do ato pedagógico e, portanto, deve ser visto como um importante agente educacional, mas de pouca manipulação nas esferas da educação não-formal ou formal.

Neste contexto, Trilla (2008) argumenta que é questionável classificar a educação informal através de sua intencionalidade. Para o autor, a educação informal dever ser compreendida pelos critérios de diferenciação e especificidade em relação às outras duas expressões, principalmente pelo fato dos processos educacionais considerados informais, como a comunicação de massa, serem cerceados de valores e intencionalidades. Então, a educação informal deve ser vista como um processo educacional que ocorre indiferenciadamente $e$ subordinadamente a outros processos sociais (TRILLA, 2008:37).

No caso da educação não-formal, ela pode ser compreendida pelos seus objetivos educacionais que se distanciam das hierarquias e burocracias, como no caso da educação formal, para conceber uma educação variável no espaço e no tempo (GADOTTI, 2005). No entanto, é importante salientar que o fato de ter uma liberdade na atuação e uma flexibilidade na adaptação dos conteúdos não implica à educação não-formal uma desorganização ou desestruturação em seu seio 
organizacional (GARCIA, 2009). Sua orientação pode ser planejada, no entanto, adaptada para instituições, organizações ou situações fora das esferas formais ou informais de educação (ESHACH, 2007).

Para Garcia, de forma restrita, o termo diria respeito a instituições, organizações, fundações, etc.; que tem a educação como mediadora nos processos de construção do conhecimento, independente do público, objetivo, conteúdo, durabilidade, espaço e lugar onde se desenvolve a proposta. Em outro aspecto, engloba todas as ações que são elaboradas intencionalmente e interferem educacionalmente na formação dos indivíduos. Em ambos os casos possuem certa formalidade, mas diferem da educação formal (GARCIA, 2009:45).

Assim, a autora destaca algumas características específicas encontradas na literatura que convergem entre os diversos seus autores: a) flexibilidade de tempo e conteúdos; b) não necessitar de uma certificação; c) não ser uma área escolar; d) ter envolvimento com a comunidade; e) relacionar-se com o cotidiano de maneira mais prática que a educação formal; f) não se vincular ao sistema legislativo escolar; g) participação voluntária e atemporal e h) favorecer a perspectiva de ação transformadora (GARCIA, 2009).

No campo da educação científica, a questão emergente entre seus estudiosos é a procura por instrumentos indicadores da diferenciação entre educação nãoformal e divulgação científica (MARANDINO et al, 2004). Seus autores enfatizam que ainda há muitos entraves entre os próprios especialistas para uma compreensão dos conceitos, sendo utilizados diferentes critérios para defini-los. Neste contexto, Garcia (2009) comenta que

o fato de relacionar os campos parece legítimo e dentro das possibilidades que a lógica da educação não-formal estimula, mas nos parece que querer definir um pelo outro, ou restringir a ação da educação não-formal à divulgação científica, é comprometer uma das características mais estimulantes deste campo que é sua possibilidade criadora, ou seja, o fato do campo da educação nãoformal poder se relacionar e promover atos criadores em sua mediação com várias e diferentes instâncias, áreas e campos. 
Entendemos que a divulgação científica é uma das esferas de ação da educação não-formal (GARCIA, 2009:168).

No entanto, é importante ressaltar que a divulgação científica e o espaço nãoformal, no que tange suas relações com a educação, nem sempre são pautados pelas mesmas finalidades e não se submetem aos mesmos trâmites burocráticos, que os legitimam em ambientes distintos. Isso implica que a divulgação científica é uma possibilidade de apresentar a ciência em outros espaços fora do âmbito escolar e, por vezes, também pode ser incluída na vida cultural de seus sujeitos através de revistas especializadas, filmes, etc. Assim, acreditamos que, como a definição de um conceito na exclusão do outro não pode ser creditada como verdade absoluta, também defendemos que a conduta de inserção da divulgação científica como uma esfera de ação do espaço não-formal nem sempre é percebida. Isso porque a finalidade educacional do espaço não-formal, por vezes, direciona-se em lado oposto ao da divulgação científica, quando esta se submete a mera apresentação de fatos e entretenimento.

Para Trilla, a educação não-formal pode ser entendida, dividindo-a em dois critérios: metodológico e estrutural. O critério metodológico da educação não-formal se aplica mediante os procedimentos ou instâncias que romperiam com determinados critérios que caracterizam a escola. Assim, processos que se distanciam das formas convencionais de conceber a educação na sala de aula, como a educação à distância, pode ser considerada uma educação não-formal. Do ponto de vista do critério estrutural, a educação não-formal seria o tipo de educação que permanece à margem do organograma do sistema educacional graduado e hierarquizado (TRILLA, 2008:40). Isso implica em uma educação que não se orienta por uma estrutura administrativa acadêmica legal e hierarquizada.

Neste contexto, a forma mais plausível de compreender a educação nãoformal é através do critério estrutural, visto que a educação não-formal é o conjunto de processos, meios e instituições específicas e diferenciadamente concebidos em função de objetivos explícitos de formação ou instrução não diretamente voltados à outorga dos graus próprios do sistema educacional regrado (TRILLA, 2008:42). 
Acreditando nas diversas formas de compreender esses espaços, Trilla sugere uma distinção que observe as fronteiras dessa educação e não somente a distinção pelas suas particularidades. A diferença então se iniciaria no como e onde se localizaria tais fronteiras. No esquema (1) proposto pelo autor, a educação formal e não-formal seria uma subclasse de um mesmo tipo de educação.

Esquema 1: Tripartição das fronteiras

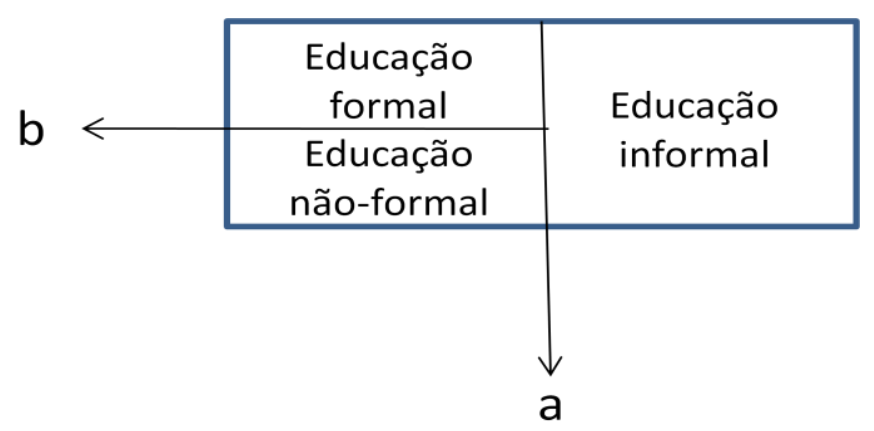

In: Arantes, V.A. Educação formal e não formal

A fronteira "a" seria entre a educação informal e as outras duas e se constitui pela especificidade ou diferenciação de suas funções educativas. A segunda fronteira "b", de nosso interesse, é entre a educação formal e não-formal.

Dentre as muitas relações passíveis de serem atribuídas a estes espaços, duas merecem destaque pela sua relação direta como o espaço formal e não-formal proposto nesse trabalho. A primeira relação é a de complementaridade, que resulta na partilha de funções, de objetivos, de conteúdos entre os diversos agentes educativos (TRILLA, 2008:46). A outra relação é a de reforço e colaboração que buscam cooperar na ação da educação formal através de recursos provenientes de outros meios fora das instituições formais; utilizados por elas no contexto de sua atividade como museus, bibliotecas, fundações culturais e que adicionaremos aqui, centros e laboratórios de pesquisa.

Apesar do esforço dos pesquisadores da área em ensino de legitimar a educação não-formal como ambiente colaborativo na educação formal, muitos concordam que ainda há muito a se trabalhar em seu favor (GHANEM, 2008). Dentre as muitas críticas, paira sobre a educação não-formal a sua intencionalidade de satisfação em curto prazo além da falsa ideia de ser uma substituição ao espaço 
formal ao término do ciclo básico escolar. Ghanem enfatiza que os problemas associados ao contexto escolar não são inerentes à educação não-formal e, portanto, definições simplistas podem esconder males idênticos aos da educação formal (TRILLA, 2008). Outro fator seriam os objetivos das atividades, que pouco claros e com clientelas indefinidas, a responsabilidade de sua manutenção e administração divide-se entre dezenas de entidades públicas e privadas (GARCIA, 2009:60).

Sobre a conceituação da educação não-formal, o que se observa é que são diversas as intenções e definições acerca de suas motivações, que nem sempre aparecem claras ou bem definidas.

Ele mostra e representa uma série de significados em função das necessidades e dos problemas que emergem e emergiram em diferentes situações. Essa atitude é determinante para entendermos que as perguntas que propiciaram a criação do conceito de educação não-formal têm a sua historicidade e que o conhecimento dessa trajetória é fundamental para a compreensão do que estamos construindo hoje. (GARCIA, 2009:40)

Geralmente, essa historicidade está ligada às muitas possibilidades da educação não-formal como estratégia para desvencilhar os conteúdos curriculares dos estatutos que regem a escola básica. A nosso ver, isso se tornaria uma perda em grande escala da capacidade do ensino - nesses espaços - criar um vínculo necessário para que novas e diferentes formas de aprender nasçam dessa parceria. Concordamos que a compreensão do conceito não pode ser pautada na exclusão ou relação da educação formal e não-formal, mas seus métodos de atuação devem ser mantidos através do dialogo, trazendo para o conhecimento pautado nas regras escolares toda a diversidade e capacidade criativa que faz da educação não-formal uma possibilidade atraente, mas não única. Enfatizando o que a

(...) educação não-formal tem de mais vantajoso, provocativo e interessante, como também no fato de não existirem modelos, de não termos "o pronto", o "é assim que se faz". É possível inventar jeitos diferentes e variados de atuar com crianças, jovens, adultos e velhos, com objetivos que valorizem e levem em conta os próprios 
interesses dos envolvidos. Também é observável que nem sempre a educação não-formal vem acontecendo dessa maneira, mas o que queremos evidenciar aqui é que, por não ter amarras e jeitos de fazer já prontos, é mais fácil que ela alcance o inusitado, o não experimentado (GARCIA, 2009:72).

Em suma, nessa seção procuramos definir o conceito de espaço não-formal, compreendendo sua ação além do ambiente escolar. Como tema recente, seu entendimento ainda sofre diversas concepções e diferentes formas de enxergar o próprio objeto estudado. No entanto, podemos acreditar que é consenso da comunidade educacional sobre a importância desses espaços para a educação científica, e que já superou a necessidade de sua justificação; assim como a postura ingênua de que atividades fora do âmbito escolar proporcionem uma aprendizagem contínua após o término do ciclo básico de ensino.

\subsection{Os Espaços Não Formais no Ensino de Ciências}

No campo da pesquisa em Ensino de Ciências são muitas as tentativas de trazer, nos espaços não formais, debates sobre a inserção de temas científicos para a sociedade. Tais tentativas buscam promover a popularização da ciência para grupos que não obtiveram contato algum com o tema nos processos de escolarização ou introduzir esses espaços como instrumentos educacionais das instituições escolares. Tais processos têm como objetivo, em geral, proporcionar o encantamento, descoberta, diversão, aprendizagem, etc.; nos indivíduos que visitam esses lugares (GRUZMAN \& SIQUEIRA, 2007).

Com o intuito de motivar essa aprendizagem de estudantes da escola básica, o Observatório Astronômico do Centro de Divulgação Científica e Cultural (CDCC) na USP, busca demonstrar os aspectos tecnológicos de estudos astronômicos (lunetas, telescópios) além de observações e palestras sobre o tema. Para esses autores, os dados demonstraram que há uma parcela relevante de alunos que, ao término da visita, apresentaram um reconhecimento maior sobre os assuntos abordados nesse espaço do museu (COLOMBO JR \& SILVA, 2007; 2009). Outra iniciativa se refere aos museus itinerantes (BONADIMAN et. al., 2005; TEIXEIRA et.al., 2010) que promovem exposições e experimentos em espaços fora do âmbito 
institucional ou museus, para promover a divulgação científica para a população em geral.

Trabalhos que buscam a inserção de um diálogo entre universidade e escola introduziram, no Museu Espaço Ciência Viva, experimentos e exposições, que, em parceria com pesquisadores do Instituto de Ciências Biomédicas da UFRJ, procuram levar esses especialistas até os espaços de exposições e também, os visitantes até os laboratórios e hospitais; abrangendo os ambientes de convivência nesses eventos científicos (COUTINHO-SILVA et. al., 2005).

O Museu de Astronomia e Ciências Afins (MAST), no Rio de Janeiro, promove exposições interativas, com ênfase em ações educacionais e na sensibilização para a ciência. Agrega ideias da preservação da memória científica, da investigação histórica sobre a ciência na educação (CAZELLI, et. al., 1999). Essas exposições são pensadas, em geral, na interação com a escola, trazendo diversos temas como: as estações do ano, laboratórios científicos, astronomia, espaço e instrumentação científica.

No que tange às políticas públicas, com o intuito de promover um maior interesse dos jovens para as carreiras científicas e o conhecimento de questões básicas sobre ciência e tecnologia, foi implementado pelo Ministério da Ciência e Tecnologia e algumas instituições de pesquisa, parcerias para promover momentos de interação entres pesquisadores e público na Semana Nacional de Ciência e Tecnologia (SNCT) (HARTMANN et. al., 2008). Essas atividades ocorrem em todo o território brasileiro, recebendo financiamentos do governo para que seus cientistas abram as portas de instituições, museus ou exponham em feiras de ciências; para que o público e grupos escolares possam ter um contato mais próximo com esses profissionais.

No âmbito da formação acadêmica, algumas tentativas de introduzir disciplinas que enfoquem o tema da divulgação científica já são feitas em instituições como no Instituto Federal de São Paulo e na Universidade Federal de Itajubá (UNIFEI). Para os idealizadores dessa última, a formação dos graduandos em Licenciatura em Física, em contato com tal tema pode trazer como resposta um responsabilidade social de seus formandos além de habilitá-los a compreender e 
ensinar o conhecimento científico através da produção de materiais destinados a divulgação da ciência (MARQUESA \& SCHEIDEGGERB, 2009).

Em consonância, essas iniciativas em divulgar a ciência trazem como objetivo apresentar ao público o conhecimento científico, através de seus conteúdos teóricos ou fenomenológicos. Apesar de essas estratégias serem diversas, em geral, possuem finalidades parecidas no que tange à sua dimensão de agregar saberes sobre a ciência e partindo dos pressupostos de sua importância para aqueles que têm contato com essas atividades.

É interessante observar que essas dimensões são modificadas ao longo do tempo para que se re-estruturem à medida que novas demandas sociais emergem em períodos diferentes da história. Assim, no Renascimento, pode se considerar como precursores de museus a organização de acervos pessoais atrelados à ascensão social de seus donos.

Os museus científicos só ganharam espaços com o advento do pensamento iluminista, em meados de 1700, quando foram instituídos na Europa diversos espaços sobre o tema. Tinham como objetivo o depósito de máquinas e inventos que pudessem ajudar na formação técnica dos profissionais da época. Tal qual em uma oficina técnica, seus visitantes podiam aprender as formas de construção e emprego dessas máquinas (GRUSMAN \& SIQUEIRA, 2007: 405).

No fim do século XVIII, com a Revolução Francesa, coube aos museus guardar, catalogar e conservar diversos materiais para fins de estudo. Apesar de esses espaços abrangerem seu público, com os ideais das mudanças sociais, tinham um olhar apenas para a contemplação desses objetos (GRUSMAN \& SIQUEIRA, 2007).

No século XIX, com a preocupação na inserção de temas científicos e na afirmação da supremacia da tecnologia no cotidiano da população, os museus iniciaram a fase de demonstrações de técnicas e congressos para visitantes. Também principiaram a produção e empréstimo de materiais para instituições de ensino, tudo em prol de uma compreensão dos objetos museológicos. Também surge, nesse momento, uma preocupação educacional, voltada para a divulgação da 
ciência, com o intuito de referendar mais seu acervo do que na comunicação com o público (GRUSMAN \& SIQUEIRA, 2007).

No início do século $X X$, novas finalidades surgem para os museus, que buscam na educação e divulgação da ciência, propor exposições interativas onde os visitantes são convidados a participar na interação com os objetos dispostos. Após a Segunda Guerra, esse tipo de exposição deixa de ter consonância com as demandas sociais e solicitam novas formas de reflexão sobre o conhecimento que é apresentado nesses espaços. Esses novos museus buscam mais do que tocar nos materiais expostos, mas em interagir com os diversos módulos de uma exposição. Oppenheimer idealizou essa relação entre a Física e os conceitos envolvidos com o objeto explorado, dando início aos centros de ciências, que privilegiavam os modelos e aparatos tecnológicos; dando ênfase aos recursos de comunicação (GRUSMAN \& SIQUEIRA, 2007).

Algumas tendências, dessa última geração de museus, enfatizam propostas pedagógicas voltadas para a ação dos visitantes em seu aprender. Assim as visitas se voltaram para as ideias educacionais de ensino-aprendizagem, onde o público dispunha de aparatos que propiciassem uma interação com o seu conhecimento, difundindo a ideia do aprender fazendo (CAZELLI, et. al., 1999). Questões de cunho sócio-histórico não eram empregadas nessas estratégias que privilegiavam os conteúdos. Para o século XXI os desafios desses espaços estão voltados ao compromisso social e educacional, de propiciar espaços de lazer e de educação para a observação, a exploração, estudo, pensamento crítico, contemplação e dialogo (GRUSMAN \& SIQUEIRA, 2007: 408).

Em diversos períodos, as finalidades dos museus científicos sofreram modificações atreladas ao contexto social e cultural de sua época. Nesse século emerge a discussão sobre quais dimensões de aprendizagem são passiveis de serem incorporadas aos visitantes quando vão a esses espaços. Para Cazelli e colaboradores (1999):

Atualmente os museus são reconhecidos como ambientes de aprendizagem ativa e seus profissionais se preocupam em saber que tipo de aprendizagem neles ocorre. Com base na literatura específica 
de educação em museus constata-se que as práticas pedagógicas neles desenvolvidas são próprias destes espaços. Como são locais que possibilitam intensa interação social entre os visitantes, exploração ativa e ricas experiências afetivas, culturais e cognitivas (Beetlestone et al., 1998), considera-se pertinente esboçar uma pedagogia que leve em conta as singularidades destes espaços não formais de educação científica (CAZELLI, et. al., 1999: 10).

Esforços para compreender tais aprendizagens em museus levaram Marandino (2007) a estudar e buscar características para o termo "aprendizagem" como um processo onde ocorrem mudanças duradouras no terreno das capacidades e condutas de um indivíduo, mudanças essas geradas a partir de fatores predominantemente externos a este indivíduo (MARANDINO, 2007:44).

Esse novo olhar para a pedagogia nos museus e centros de ciência reflete uma postura de modificação acerca do papel educacional desses ambientes na formação do alunado da escola básica e da população em geral. A tentativa de incorporar a aprendizagem das ciências nesses espaços decorre da compreensão do sentido do termo no contexto da pesquisa em educação. Para Pozo e Crespo (2006) aprender ciência perpassa

(...) não só de que o aluno conceba a ciência como um processo construtivo, mas de que realmente tente aprendê-la de um modo construtivo, adotando um enfoque profundo em vez de superficial, aprendendo na busca do significado e do sentido, e não só repetindo; trata-se, também, de que o aluno se interesse pela ciência, que a valorize como algo cuja compreensão é digna de esforço e que gere autoconceito positivo com respeito à ciência, que acredite que é capaz de aprendê-la, que, em resumo, tenha motivação para aprender ciência e não só para aprovação na disciplina (POZO \& CRESPO, 2006: 38-39)

No entanto, ainda existe na área em educação uma limitação sobre os elementos que podem caracterizar a aprendizagem nesses espaços, como lembram Toharia e Frutos (2004), que: 
A natureza exata e a extensão da aprendizagem em centros de ciência não são completamente conhecidas. Isto não é surpreendente devido à natureza episódica da interação, a divergente procedência dos visitantes, a natureza livre da própria visita ao museu e o caráter não verbal das experiências que se realizam nos museus. Assim como nenhum visitante é avaliado após sua visita. (TOHARIA \& FRUTOS, 2004: 279 - tradução livre).

Nesse sentido, incorporados no contexto dos museus, para Cazelli et.al. (1999) tal aprendizagem perpassa aspectos da negociação entre o visitante e o objeto do conhecimento científico, visto que esse último não pode ser apresentado da mesma maneira que concebido no contexto do saber da ciência. Essa reelaboração do conhecimento, também pensada sob as ideias da transposição didática de Chevallard, remete à transposição do saber de referência ao contexto do museu, ou seja, à transposição museográfica (CAZELLI et. al., 1999).

Segundo os autores, ela possibilita a inserção de abordagens diversas que evocam saberes epistemológicos, sociológicos e linguísticos; com a preocupação de integrar esses conhecimentos nas exposições, proporcionando significado aos temas expostos. No processo de transposição museográfica, modelos consensuais da ciência se transformam em modelos pedagógicos que podem ou não levar em conta os modelos mentais dos visitantes (CAZELLI, et. al., 1999: 11).

Para a transposição didática, o saber sábio provindo daqueles que produzem a ciência deve se modificar e reorganizar a fim de suprimir dificuldades (matemática como nos trabalhos originais) no processo de aprendizagem. Dessa forma, para Chevallard, os conteúdos de saber designados como aqueles a ensinar são verdadeiras criações didáticas, suscitadas pelas necessidades do ensino. Esse trabalho de transformação de um objeto de saber em um objeto de ensino é o que ele chama de transposição didática (MARANDINO, 2004: 98).

A crítica a essa concepção de um saber único, como referência ao saber a ser ensinado, ignora a esfera social pela qual, na medida que são inseridas novas demandas no campo educacional, requerem novas construções que não são 
estritamente do campo acadêmico onde é gerado, em sua maioria, o conhecimento científico. Para Marandino (2004)

O referencial teórico da transposição didática/museográfica ajuda a perceber que, na socialização do saber científico, este se constitui como um dos elementos que fazem parte da construção do saber escolar/museal. Mas ele não é o único, pois outros saberes também participam da constituição do saber educacional; o mesmo valendo para os museus: na elaboração das exposições, outros elementos entram no jogo de constituição do saber exposto (MARANDINO, 2004: 102).

Para a autora, o discurso pedagógico perpassa por regras recontextualizadoras que, baseado nas ideias de Bernstein, pode ser construído a partir de regras que se remetem a competência e regulativo. Em resumo, possui como finalidade selecionar, apropriar, refocalizar e relacionar, a partir de uma ordem que se referencia como outro discurso. Nessa perspectiva, Marandino busca compreender como os discursos expositivos nos museus possuem outras dimensões educativas que perpassam a própria instituição escolar.

As especificidades dos espaços, tempo e objetos dos museus, também possuem papel social, mas, no entanto, se refletem de maneira diferenciada nesses ambientes. Assim como a dimensão do discurso expositivo tem outros fins que não somente os relativos aos processos educacionais e de aprendizagem, podendo ter finalidades múltiplas como entretenimento, por exemplo. Desse modo, postula-se que o discurso expositivo é um discurso particular que, por possuir objetivos específicos e recolocar outros discursos a partir de sua própria lógica, pode também se comportar como o discurso pedagógico (MARANDINO, 2004: 107).

Essa necessidade de saberes mais amplos, como função necessária na concepção do discurso expositivo nos museus, emergiu de novas demandas acerca das mediações nesses espaços, enfatizando seus aspectos educativos como facilitadores da aprendizagem. 


\subsection{Os Museus e as Mediações nos Espaços Não Formais}

Nos últimos anos, com o advento do movimento de alfabetização científica, (QUEIRÓZ et al, 2002; QUEIRÓZ, 2010) muitos museus e centros de ciências ganharam importante papel na formação científica dos cidadãos. Esses tipos de espaços não formais receberam à sua importante relevância no Brasil e no exterior devido a sua capacidade de abranger diversos públicos e permitir que sujeitos, fora do contexto escolar, pudessem aprender sobre ciência em situações vivenciadas de forma não-convencional.

Para Queiróz esses museus podem ser compreendidos como um sistema complexo, não diferente da sala de aula. Para a autora:

O que justifica essa afirmação é o número grande de variáveis presentes numa visita guiada: o tema abordado na exposição, a forma como está exposto o tema (...), o objetivo dos idealizadores, o interesse dos visitantes, suas concepções alternativas, seu nível sócio-econômico, as vivências culturais do seu cotidiano; o conhecimento do mediador e seu repertório de técnicas e habilidades. Durante a visita, os elementos apresentados se interligam, influenciando mutuamente uns aos outros e determinando a qualidade da visita (QUEIRÓZ, 2010:284)

Partindo dessa ideia, os museus e centros de ciências se caracterizam pela sua dimensão institucional, que fazem deles meios de disseminação de um determinado conhecimento, estudado e pensado, em seus contextos. Apesar de no país não haver uma diferenciação entre museus e centros, Jacobucci (2008) indica que:

No exterior, é nítida a diferenciação entre os centros de ciências e os museus de ciências, uma vez que os museus de ciências necessariamente possuem coleções de organismos ou minerais em seus acervos e pessoal técnico direcionado à pesquisa científica, sendo muitas vezes possível ao visitante observar os laboratórios e vivenciar o cotidiano do cientista. Em contraposição, os centros de ciências utilizam material biológico e mineral apenas para fins didáticos, concentrando-se em atividades de popularização científica. 
No Brasil, esses espaços não-formais de Educação são tratados de forma similar e os termos são utilizados como sinônimos (JACOBUCCI, 2008: 61).

Para Gaspar (1993) os museus e centros de ciências, quando considerados como instituições de educação não formal, possuem como objetivo principal promover a alfabetização científica. Segundo ele, da mesma forma, museus e centros de ciências certamente poderão desenvolver essa tarefa em condições mais favoráveis que a escola, pois não têm as limitações de uma instituição de ensino formal, e com maior competência que a mídia impressa e eletrônica, pois, entre outros fatores, estão livres das imposições de seus empresários em busca de lucro e audiência (GASPAR, 1993: 42).

No entanto, um fator comum nesses espaços é o papel da mediação, que ocorre entre aqueles que pensam as visitas e o público em geral. Geralmente, essa mediação é centrada na figura do monitor, cuja função é promover o diálogo com os visitantes. Para aqueles que trabalham nesses espaços, sua função é fundamental para preencher o vazio que muitas vezes existe entre o que foi idealizado e a interpretação dada pelo público ao que está exposto, consideramos que a mediação requer um saber com dimensões peculiares: o saber da mediação (QUEIRÓZ et al, 2002). Esses saberes de mediação estão associados a dimensões complexas, que envolvem tanto o conhecimento científico como o mundo daqueles que visitam e dos seus idealizadores.

Em geral, esse termo está associado a uma apropriação do conhecimento, através da linguagem, cuja finalidade é permitir aproximar dois mundos, como o do público e o do laboratório, inicialmente estranhos entre si, para que o primeiro possa, de certo modo, se apropriar do segundo (NASCIMENTO, 2010). Para Anne Fauche (2008), a palavra mediação refere-se a uma negociação entre especialistas e técnicos e os diferentes públicos.

Nascimento (2010) afirma que se podem assumir quatro funções para a mediação dentro de um museu científico: 
1) Tradução de um significado a outro; 2) ligação estática entre o sujeito e os objetos; 3) transformação de significados atribuídos pelo sujeito a objetos de hierarquias diferentes e 4) transformação de significados a partir de ações do sujeito sóciohistórico sobre os objetos das culturas (NASCIMENTO, 2010: 142-143)

Assim, essa mediação científica pode se tornar diferente do ensino de ciências pelo seu contexto, pois ocorre em espaços diferentes do escolar e está centrados em objetivos diversos atrelados ao discurso expositivo do museu, assim como em suas especificidades (MARANDINO, 2004; FAUCHE, 2008). Isso se reflete na própria definição da ICOM (International Council of Museums) no art. $2 \S 1$, onde se define que:

O museu é uma instituição permanente, organizada sem fins lucrativos, servindo a sociedade e seu desenvolvimento, aberto ao público e à pesquisa, conduzindo testemunhas materiais e imateriais do homem e de seu ambiente, com o intuito de preservar, comunicar e expor; para fins de estudos, educação e diversão. (ICOM, 2007: art.2§1).

Esse contexto particular de mediação científica aponta para modalidades de interação possíveis nesses ambientes, que Fauche (2008) lista como a mediação direta, a mediação indireta e a gestão do projeto e formação. Todas elas buscam trazer ao público o conhecimento científico em diferentes interesses sobre esse saber.

A mediação direta se relaciona com a interação humana entre os sujeitos, onde o mediador é capaz de perceber e ponderar sua fala e atitudes, através do contato direto com o público, criando, para cada grupo uma dinâmica própria de atuação. Em geral, os conteúdos apresentados por esses sujeitos precisam deixar de ter valor "em si", para serem repensados para o público. Tal ponto de vista é fundamentalmente diferente do cientista, pois reflete uma percepção menos aprofundada do tema, que pode ser problemática, mas, em contrapartida, aproxima o leigo do conhecimento que se quer apresentar. Esse mediador, mais do que apresentar, tem a finalidade de pensar sobre as especificidades do público e, 
quando necessário, utilizar de seu saber para o aprofundamento do tema, para aqueles que se interessam pelo assunto (FAUCHE, 2008).

A mediação indireta, também conhecida como "mediação de apoio", tem a finalidade de desenvolver documentos, materiais, vídeos, áudio, etc. para visitas, e sendo usada em contextos educacionais. Assim como na mediação direta, a intenção é promover um diálogo com o público, trazendo aspectos desse conhecimento para um entendimento dos contextos vividos nos espaços não formais. Seu objetivo só é alcançado quando essa interação se dá de forma articulada com a mediação direta.

A gestão do projeto e formação se aproxima da mediação direta e indireta através de um mediador, cuja responsabilidade é pensar os projetos e eventos, gerenciando-os e montando-os. Envolve parceiros externos ao museu, como cientistas, artistas e técnicos, com a finalidade de aprimorar habilidades e expandir as intenções desses espaços para outros públicos ou contextos. Ele possui a função de treinar e aplicar o que foi idealizado, procurando promover a interação entre a mediação direta e indireta com o público.

A intenção associada à mediação da gestão do projeto, no entanto, só poderá ser efetivada quando a mediação indireta, relacionada aos materiais produzidos para as exposições, e a interação direta, entre mediadores e público, for pautada nos saberes de mediação. Para Queiróz e colaboradores (2002) esses saberes são diversos e se relacionam com o contexto escolar, do museu e da concepção da exposição.

Para os autores, o compartilhamento do saber se dá em quatro instâncias: os saberes compartilhados com a escola, os compartilhados com a educação em ciências, os saberes próprios dos museus e o saberes da relação museu-escola.

O primeiro, associado ao saber compartilhado com a escola, inclui o saber disciplinar, que é o conhecimento do conteúdo científico, o saber da transposição didática, que é a capacidade pedagógica de tornar a informação acessível ao público, o saber do diálogo, que é estabelecimento da proximidade com os visitantes 
e o saber da linguagem, que se refere a adequar a linguagem aos diferentes públicos.

O segundo compartilhamento se dá com a escola em sua relação com a educação em ciências. Isso reflete no saber da história da ciência, que implica em conhecer o conteúdo histórico relacionado à exposição e o diferenciando do conteúdo da ciência atual. O saber da visão de ciência que implica em conhecer a origem do conhecimento da ciência, seus processos de construção e sua posição ante outros conhecimentos da sociedade. O saber das concepções alternativas, que são relacionados ao compreender as diferentes formas de compreender o conhecimento científico, atrelado geralmente a outras formas de explicar um problema.

O terceiro saber está associado aos museus, e implica em compreender as dimensões de saberes envolvidos na imersão do lugar visitado. Assim o saber sobre a história da instituição implica em conhecer o lugar onde se abriga a exposição no museu. O saber da interação com professores, que se relaciona a como lidar com os docentes que trazem seus alunos. O saber de conexão, que implica em conectar diferentes aparatos da exposição de um espaço. O saber da história da humanidade, que é situar o tema apresentado em um contexto histórico-social mais amplo (QUEIRÓZ, et.al. 2002).

O último saber, relacionado ao compartilhamento museu-escola, segundo Queiróz (2010), indica claramente uma complementaridade adotada por professores entre atividades realizadas na escola e a visita ao museu (QUEIRÓZ, 2010). Essa complementaridade indicada pelos docentes, encontrou nos saberes da mudança conceitual, dos projetos e da ampliação cultural, uma interlocução com a escola, a fim de promover novas funções para os espaços não formais dentro dos projetos políticos pedagógicos.

Esses saberes de mediação são, em sua maioria, conhecimentos necessários para que as mediações diretas criem vínculos entre aquilo que é apresentado e o público. Um aspecto relevante desse mediador, quando olhado sob o ponto de vista da Física, se direciona para a transposição dos conceitos físicos nesses espaços não formais (FALCÃO, 2007). Essa transposição didática 
(...) estrutura-se de forma a possibilitar que os visitantes elaborem processos de modelagem essencialmente qualitativos em diferentes níveis. A física nos museus é essencialmente qualitativa, ou seja, os aspectos quantitativos dos fenômenos não são focados nos aparatos, oficinas e exposições (FALCÃO, 2007:291).

Nessa perspectiva, o papel da mediação é o de promover experiências para os visitantes que sejam capazes de explorar a física, de forma que tais interações gerem interpretações compatíveis com os modelos científicos (FALCÃO, 2007:294). Essa tentativa, em geral, é associada a experiências e na observação de fenômenos, geralmente, associados à Física Clássica.

Em suma, os espaços não formais aparecem, de forma geral, como ambientes capazes de promover a educação em âmbitos fora do contexto escolar. Nesse sentido, os museus e centros científicos podem se caracterizar como meios para a disseminação da ciência e procuram, em trabalhos mais recentes, promover o diálogo com a escola básica. Essa dimensão está atrelada ao próprio saber de mediação, ou seja, do material, do interlocutor e do idealizador; que proporcionam encaminhamentos para dar sentido ao que é exposto nesses espaços.

Nessa discussão é possível observar que o próprio entendimento dos conceitos que demarcam os espaços e funções torna-se complexo, seja pelo seu caráter de atuação ainda não definido ou pelas diversas compreensões possíveis, quando se referem aos espaços não formais. De certo modo, situar-se nessas discussões é necessário, para se compreender em que dimensões o laboratório científico pode se aproximar em relação a essas concepções e, ao contrário, em que momentos se distância deles.

O discurso se torna consonante quando se entende que, assim como os espaços não formais, o laboratório também possui uma postura diferente de lidar com a educação, sendo entendida de maneira mais abrangente em seu campo de atuação. Em outras palavras, os laboratórios podem, também, buscar promover o ensino não formal, no sentido que se atribuiu ao termo... 
No entanto, esse mesmo laboratório não pode ser considerado como espaço não formal. Isso porque quando esse debate procura sistematizar a ideia do espaço não formal reflete um ambiente que, apesar de ser aberto em relação às suas escolhas, ainda assim, possui uma organização peculiar que direciona seu foco ao ambiente de aprendizagem. Essa característica indica ambientes pensados para divulgar e educar, em diversos níveis, sendo obedecidas regras de organização e cuidado no preparo de pessoal para pensar e produzir, nessas instituições. Essa linearidade de apresentação do conhecimento científico como ocorre nos museus, traz um distanciamento dos laboratórios científicos, pois reflete ambientes preparados para receber um público e em geral, constrói as exposições em função desses visitantes.

No caso dos laboratórios científicos, esse não é o caso, pois trata-se de um ambiente pautado na produção do conhecimento e direcionado para que sejam ambientes de trabalho do cientista. Nesse local ele faz o experimento, sem, no entanto, se preocupar com questões de estética ou a relação entre os conteúdos atrelados às máquinas e com o que será apresentado.

Outro aspecto interessante sobre os espaços não formais é seu entendimento de complementaridade com a escola. Ele se posiciona como um reforço ou extensão sobre aquilo que é aprendido e busca a colaboração com outras instituições, trazendo uma função de interação inata ao se pensar esses ambientes. Esse mesmo entendimento pode, também, ser estendido aos laboratórios, quando são pensadas as possíveis articulações das visitas com a educação escolar

Em relação à aprendizagem, essas questões aparecem de forma menos pragmática nos espaços não formais do que na escola, pautando-se em formas de interagir com o meio e os objetos; proporcionando novas sensações sobre a ciência e abrangendo esse conhecimento para despertar o interesse sobre os temas científicos, sem configurar uma relação de dependência entre aquilo que é apresentado e sua relação direta com o conteúdo apresentado

Ao mesmo tempo, e considerando que seria desejável para os laboratórios atuarem em uma perspectiva de complementaridade com a escola, esses aspectos podem ser buscados, mais especificamente, privilegiando contribuições vindas de 
experiências que não são passiveis de serem contempladas no ensino formal, visando uma formação humana integral mais ampla.

Esse sentido de aprender nesses espaços traz, de certo modo, algumas indicações nos saberes de mediação e que podem ajudar a compreender as relações estabelecidas nas visitas aos laboratórios científicos. Cada um desses saberes é parte de uma intersecção necessária entre os espaços não formais e a escola; e, podendo, ser inseridos no contexto do acelerador, pois evocam diferentes conhecimentos que são necessários para mostrar aquilo que foi idealizado, respeitando as expectativas dos indivíduos que fazem parte desse processo.

Assim, tomamos emprestadas algumas das concepções educacionais sobre espaços não formais, dos museus científicos e da discussão sobre mediação; procurando iniciar a trajetória de compreensão sobre o papel dos espaços de produção da ciência no campo da educação. Enfatizando aspectos que abrangem esses ambientes como lugares de formação científica e respeitando as singularidades que fazem do acelerador Pelletron, um objeto de estudo particularizado em relação aos museus e centros de ciências.

Em suma, para atingir os objetivos educacionais nos espaços não formais, salientamos ainda, que mais do que disseminar a ciência, ou seja, apresentar os conhecimentos ou produtos provindos desse saber científico, tais ambientes devem promover a ciência levando em conta os seus processos de produção e os contextos sociais em que eles ocorrem, como preconizam as ideias da divulgação científica. 


\section{Capítulo 3}

\section{O que são os laboratórios científicos?}

Enquanto eu tiver perguntas e nã̄o houver

respostas, continuarei a escrever

Olarice Eispector

Comunicar a ciência, apresentar a ciência, popularizar, vulgarizar ou divulgar a ciência, são alguns dos termos utilizados pelos especialistas sobre as tentativas dos cientistas de mostrar seu trabalho para um público leigo. São muitas as formas de se fazer isso, geralmente, em parcerias com jornalistas ou educadores, que procuram "transpor" ou "traduzir" o conhecimento específico científico para leitores ou visitantes, que em geral não possuem o entendimento necessário para compreender todas as terminologias e contextos, associados ao que é apresentado.

Existem, portanto, algumas maneiras diferentes de se olhar as tentativas de interlocução entre os cientistas e o público: textos de divulgação científica, em espaços midiáticos (documentários, entrevistas, seriados, etc.) e no diálogo direto com o público, independentemente dos espaços (mesa redonda, cursos de formação, palestras, saraus, etc.) em que haja momentos de trocas de ideias. Todos eles possuem em comum, a tentativa de aproximar o público do conhecimento científico.

No entanto, esses saberes dos cientistas são diversos e complexos, imersos em teias de conhecimento que, a medida que se tornam mais interessantes, trazem consigo, também, a dificuldade de entendimento. Esse conhecer é invariavelmente associado a ampliar o que se vê ou conhece sobre a ciência, é entrar no mundo dos cientistas e buscar compreender como esse "fazer intelectual" se constrói, também, nas relações sociais. Procurar esse "entender mais" e de forma mais profunda, implica em fazer o caminho inverso, ou seja, ao invés de ouvir e ver o que o cientista tem a dizer, refere-se a entrar em seu mundo e observar aquilo que ele faz.

Essa perspectiva de ampliar o conhecimento sobre os cientistas e seu mundo envolve, em sua maioria, a procura por compreender os laboratórios científicos sob 
a concepção da sociologia da ciência (LATOUR \& WOOLGAR, 1979; TRAWEEK, 1988; SILVA, 2002) e no campo educacional, na formação de professores (VIANNA, 1998; VIANNA \& CARVALHO, 2001).

Assim, nossa tentativa nesse capítulo é trazer um panorama sobre as visões do que são os laboratórios científicos, buscando contextualizar os sentidos atribuídos a esses espaços no campo da sociologia e do ensino. Ao final, procuraremos realizar uma reflexão sobre essas dimensões, relacionando-as ao laboratório Pelletron, e sobre como esse espaço se articula ao campo da educação.

\subsection{A percepção da sociologia da ciência sobre os laboratórios científicos}

Alguns estudos da sociologia, que se remetem ao campo da construção dos fatos científicos, procuram, através de estudos etnográficos, abordar como a relação entre os agentes da ciência e o mundo social e cultural se conectam para a promoção de um conhecimento. Para isso, seus pesquisadores abordam, geralmente, duas técnicas metodológicas da antropologia: a observação e o estranhamento; que juntas procuram criar o ambiente social do cientista, através da reconstrução do dia-a-dia do laboratório, sem a imersão intelectual ou a familiarização do pesquisador nos conhecimentos associados ao laboratório descrito (SILVA, 2002). Esse tipo de estudo procura duas compreensões, como cita Edna L. da Silva (2002):

Numa visão macro, nessa abordagem, significaria dizer que o conhecimento científico e a ciência "não seriam entidades autônomas e independentes da sociedade e sim produtos da estrutura e dinamismo dessa sociedade" (FREITAG, 1979, p. xv). Numa visão micro, equivaleria a dizer que o conhecimento científico produzido em determinado contexto, traz a reboque os efeitos da organização social do ambiente de pesquisa, as idiossincrasias dos produtores (os cientistas) e as limitações impostas pelo meio (em termos operacionais, tecnológicos e de acesso à informação, por exemplo), enfim, reflete a cultura do contexto em todas as suas peculiaridades. (SILVA, 2002) 
Isso implica em olhar para esses estudos como condições peculiares do fazer científico, pois evocam ambientes singulares e contexto específicos, compromissados com seu tempo geográfico e histórico, cuja função primeira é compreender o fazer científico como um momento atrelado ao ambiente, aos sujeitos e ao contexto cultural e social desse laboratório. Sharon Traweek, que entrou no acelerador linear de Stanford para compreender essa construção do fato científico, concluiu que as estratégias e táticas de qualquer grupo de cientistas serão substancialmente diferentes e de acordo com o repertório cultural de cada grupo (TRAWEEK, 1988: 156). Assim, podemos afirmar que cada laboratório é um laboratório singular, com sujeitos únicos, momentos específicos em ambientes sociais e culturais também particulares.

Optou-se, nesse trabalho, por restringir as discussões sobre sociologia da ciência com o estudo do trabalho de Bruno Latour que antecedeu o de Traweek e se constituiu da entrada no laboratório de neuroendocrinologia do Instituto Salk na Califórnia. Mais tarde Latour se uniria a Steve Woolgar pra escrever, após dois anos sobre esses estudos etnográficos, suas percepções sobre a construção dos fatos científicos. Nesse trabalho, o estranhamento associado aos conteúdos científicos do laboratório aparece como forma de promover o distanciamento com o objeto estudado. Para os autores

Essa ideia de que um bacharel em ciências exatas pode falar com maior intimidade sobre o mundo da pesquisa do que um observador que nele se imiscuiu durante vários anos é claramente um preconceito que derrubamos sem o menor pesar (LATOUR \& WOOLGAR, 1979:19)

Porém, enfatizam as limitações compreendidas nesse contexto de estudo, trazendo três situações que merecem ser salientadas antes da leitura e inferências dos etnólogos acerca dos dados apresentados.

1) A distinção do contexto da descoberta e da justificação, que demandaria o olhar para o todo do processo que o estudo nesse laboratório não dá conta de fazer;

2) A limitação pelo fato do laboratório se ocupar de fatos e não de teorias; 
3) O laboratório estudado promove a compreensão do trabalho empírico, mas não se preocupa em explicitar sobre os processos de construções e teorias da ciência. Segundo eles, seria preciso estudar os físicos (Traweek, no prelo ${ }^{3}$ ) ou os matemáticos (Livingstone, 1985) (LATOUR \& WOOLGAR, 1979:33) para isso.

No entanto, algumas dimensões associadas ao fazer científico, nesse trabalho, trazem importantes componentes para a compreensão do laboratório. $\mathrm{O}$ primeiro deles se refere ao que os autores chamam de inscritores. Esses elementos são as máquinas que são encontradas em alguns desses ambientes e dão certa legitimidade aos trabalhos desenvolvidos por cientistas desse espaço.

O inscritor produz inscrições que podem, por sua vez, servir para que se escrevam artigos ou para que se façam intervenções significativas, concebendo aparelhos a partir de teorias já estabelecidas. Essa transformação, por sua vez, produz novas inscrições, novos modelos e, se a ocasião se apresentar, novos aparelhos (LATOUR \& WOOLGAR, 1979:64)

Os autores enfatizam que além, desses aparelhos, o laboratório se apropria do potencial produzido por outras áreas de pesquisa para tomar emprestado alguns saberes, passíveis de serem incorporados ao sistema de construção do fato científico, sem necessariamente, fazer parte de um domínio do conhecimento daquele que o produziu (LATOUR \& WOOLGAR, 1979). O que, no entanto, chama atenção em relação a esse conhecimento técnico é que esse ambiente material possui dupla característica: ele é o que torna possível o fenômeno e é dele que se deve facilmente esquecer (LATOUR \& WOOLGAR, 1979:67). Essa consideração, em suma, reflete a preocupação do cientista em apresentar dados na produção de artigos, sem demonstrar, de maneira detalhada, aspectos de coleta de dados associados ao fazer científico.

Outro fator importante que emerge dos trabalhos de Latour e Woolgar, e que queremos salientar, é a credibilidade da ciência, na perspectiva de seus

\footnotetext{
${ }^{3}$ O trabalho de Sharon Traweek (1988) ainda não tinha sido publicado na época da escrita dos trabalhos de Latour e Woolgar (1979).
} 
pesquisadores. Ao olhar para a construção social dos fatos científicos, ou seja, sobre como as relações entre sujeitos, instituições, objetos e pensamentos aparecem como elementos capazes de construir os fatos da ciência, trouxeram, nesse trabalho, um apelo ao que é considerado como elemento motivador para um cientista.

O crédito, mesmo que não citado pelos pesquisadores, é, segundo o autor, o principal objetivo a ser alcançado pelos cientistas. Tal situação não se refere a uma simples dimensão de apoio entre os colegas, mas evocam interesses de financiamento ou confiabilidade dos fatos obtidos. A credibilidade procurada seria, então, uma postura menos altruísta de seus personagens, para se caracterizar em interesses mais amplos, particulares ou de seus grupos.

A produção de dados confiáveis, como vimos, é um meio de ativar o ciclo de credibilidade e de pôr em movimento o "comércio da ciência" (...) Mais tarde, os pesquisadores podem empenhar-se para converter credibilidade em proveito próprio. (LATOUR \& WOOLGAR, 1979:262)

Essa percepção acerca da ciência, como lembram os próprios autores, são, em resumo, aspectos singulares de um laboratório e trazem algumas concepções que podem ser percebidas em outras instituições, como os inscritores e a credibilidade procurada pelos cientistas.

No entanto, essas percepções, quando direcionadas para grupos maiores, como os dos aceleradores de partículas, criam dinâmicas específicas e acabam por introduzir discussões mais complexas sobre esses processos. Uma tentatvia dessa natureza foi realizada pela historiadora e antropóloga da ciência Sharon Traweek durante 15 anos em que conviveu com cientistas em diversos laboratórios do mundo como: o High Energy Physics in Tsukuba (Japão), Fermi National Accelerator Laboratory em Chicago (EUA), CERN em Genebra (Suiça) e Stanford Linear Accelerator em São Francisco (EUA). O trabalho iniciado nos anos 70 acarretou na publicação, em 1988, do livro "Beamtimes and Lifetimes: the Word of high energy physics". 
Para o estudo desses espaços, a autora se pautou em três símbolos-chave da cultura do laboratório: experiências dos físicos, os artefatos chamados detectores e o modo de pensar dos cientistas. Tais táticas ajudaram a mapear o campo de estratégias e o reconhecimento dessas dimensões, a serem aceita na comunidade (TRAWEEK, 1988: 15).

A autora ressalva que em nenhum laboratório existem tantos detectores como nos aceleradores, recebendo partículas aceleradas. Os lugares onde existem esses detectores contrastam fortemente com outros equipamentos de investigação de outros campos de pesquisa. Na pesquisa biológica, ela lembra que esses equipamentos não são construídos ou projetados pelos cientistas. Geralmente, as teorias e práticas nessas máquinas são aceitas amplamente e sua validade não é questionada por anos ou décadas. E ressalva, no trabalho de Latour e Woolgar, que o estudo no laboratório vivido descreve as ferramentas utilizadas, na rotina dos pesquisadores, sem um interesse dos mesmos por descrever o funcionamento das "caixas pretas" que eles usam (TRAWEEK, 1988). No caso dos aceleradores, os detectores não são "caixas pretas", pois fazem parte da construção do conhecimento, ou seja, para a autora, inventar essas máquinas faz parte da descoberta da natureza.

Outro elemento que é específico do laboratório de Física é a necessária distinção entre o experimental e o teórico. No geral, eles possuem padrões da carreira diferentes tendo, os físicos teóricos, redes de colaborações menores dos que os físicos experimentais. Esses últimos possuem grupos maiores que incluem: engenheiros, assistentes, técnicos, etc., enquanto os teóricos fazem trabalhos de "gabinetes de escritório".

Para Traweek (1988), a construção dos fatos científicos se dá em dimensões mais amplas, onde a experimentação não é somente a coleta dos dados, mas evoca conhecimentos aprofundados sobre as questões estudadas, sendo acumulados historicamente, por aqueles que promovem esse desenvolvimento. Enfatiza ainda, que o pensamento dos físicos possui alto grau de racionalidade, que, segundo os pesquisados, fazem parte, até certo ponto, de uma característica necessária para a produção dos fatos científicos. 
A partir dessas ideias, podemos caracterizar o laboratório científico como um espaço singular de atuação do cientista, pois se apresenta como parte do processo de criação na ciência. Essa particularidade aparece nos trabalhos de sociologia e antropologia da ciência: através dos inscritores, representados pelos detectores nos aceleradores de partículas estudados por Traweek (1988).

\subsection{Os laboratórios de pesquisa no campo da educação em ciências}

Uma percepção do laboratório de pesquisa no campo da educação foi delineada em 1998, na tese "Do fazer ao ensinar ciência" de Deise Miranda Vianna, defendida na Faculdade de Educação da USP. Esse trabalho tinha como finalidade verificar se professores da disciplina de Biologia da escola básica modificariam suas práticas ao participarem de um curso de extensão, elaborado e ministrados por pesquisadores de um laboratório de parasitologia da FIOCRUZ-RJ.

Vianna propunha, nessa perspectiva, acompanhar o grupo de cursistas trazendo relatos e entrevistas com os pesquisadores e idealizadores do curso, para compreender, à luz das ideias de Latour e Woolgar, como são apresentados os fatos socialmente construídos nos laboratórios pelos cientistas, acompanhando as aulas desses profissionais. Além disso busca investigar como tal tema poderia ser inserido na sala de aula, através de entrevistas com os docentes/cursistas. Segundo a autora:

“(...) juntamos, de um lado, a pesquisa que é feita nos laboratórios, observando se os pesquisadores que dão um curso de atualização expõem os problemas da construção do conhecimento da sua área ao apresentá-la, isto é, se a vida destes cientistas nos seus laboratórios, contada por eles, apresenta um paralelo com as afirmações de WOOLGAR E LATOUR (1988, 1989, 1994, 1997). Do outro lado, investigamos se os cursistas que assistem às palestras $\mathrm{e}$ vivenciam o dia-a-dia dos pesquisadores modificam a sua maneira de ver a Ciência e mostram interesse em modificar a sua prática docente. Assim, estamos buscando estabelecer a relação entre FAZER CIÊNCIA 〈- ENSINAR CIÊNCIA" (VIANNA, 1998: 21). 
Em outro trabalho a autora, enfatizando a entrada no laboratório de física, traz a ideia principal que permeia essas discussões:

A concepção de ciência que está por trás dos conteúdos transmitidos não pode ficar escamoteada. Que experiência em pesquisa têm os professores do ensino fundamental, que mal entraram num ambiente de pesquisa, seja teórico e/ou experimental? A questão é que sendo professor e/ou o aluno de Licenciatura em Física uma pessoa que nunca acompanhou ou mesmo fez uma pesquisa em Física, ele não poderá passar a ideia de como a ciência é produzida. Estaremos limitando ao ensino e pesquisa na área de Física, pois está é a ciência em que temos formação (VIANNA, 1996:96)

Essa imersão, pensada por Vianna, trazia como justificativa para a introdução das ideias de Latour e Woolgar, os elementos que possibilitam, segundo a autora, a compreensão da produção da ciência. Tal concepção interpreta e desmistifica com muito mais atenção o empreendimento científico que servirá para a sociedade (VIANNA, 2001: 18). Possibilita, no caso dos cursistas, que entendam como dialogam, comportam e interagem os pesquisadores (VIANNA \& CARVALHO, 2000).

A medida que os cursistas puderam entrar nos espaços dos pesquisadores, vivenciando situações diferenciadas, segundo a autora, também puderam promover uma reflexão sobre o cotidiano do laboratório, esperando assim que esta mudança (dos professores) na postura pedagógica se dará na medida em que o diálogo com pesquisadores, com colegas, refletindo sobre a sua visão de como a ciência é construída, poderá levá-los a transformações mais eficazes (VIANNA, 1998: 37).

Os resultados das entrevistas com os cursistas e a interação com as aulas dos pesquisadores trouxeram, como reflexão desse trabalho, três dimensões de abordagens para a formação continuada de professores:

- Conteúdos atualizados nas áreas científicas e didáticas, proporcionando atualização e aprofundamento em conhecimento aos participantes; 
- Imersão no meio científico, proporcionando uma visão de ciência em construção e mantendo um contato permanente com os produtores do conhecimento científico e educacional;

- Investigação de prática docente, para reflexão e aplicação dos conteúdos atuais e pertinentes aos níveis de ensino e às características dos alunos (VIANNA \& CARVALHO, 2001).

Em suma, os trabalhos de Vianna mostraram que a imersão dos professores no ambiente de trabalho dos cientistas proporcionou uma reflexão sobre a produção do conhecimento científico, sendo capaz de apresentar, na fala desses pesquisados, indícios de mudança em sua atuação pedagógica. Esse trabalho, em função de sua visão no campo da formação continuada, trouxe importantes subsídios para a atualização dos docentes das escolas básicas, enfatizando uma visão menos pragmática e estigmatizada da construção da ciência.

\subsection{A inserção do laboratório Pelletron no campo educacional}

Vimos, nas seções anteriores, algumas visões sobre os laboratórios científicos pautadas na sociologia da ciência. Vimos, também, como a interação nesses espaços pode, eventualmente, vir a promover uma mudança na prática pedagógica de docentes da escola básica. A tarefa dessa seção é buscar compreender quais premissas devem ser pensadas quando centros de pesquisas abrem suas portas para o público, buscando dialogar com a sociedade sem, no entanto, uma estruturação focada em uma aprendizagem sistematizada e sem uma sequência lógica de formulação de visitas como nos espaços não-formais.

Delimitar o caso de laboratórios, mais especificamente, o acelerador de partículas Pelletron, como espaço não-formal de ensino, pode trazer diversas facilidades no que se refere a suas características como ambiente fora da escola e sua não linearidade de ensino, dispensando-o de regras e grades curriculares. No entanto, outros fatores dificultam essa classificação quando olhamos suas características como: sua constituição feita de objetos técnicos não-didáticos, sua estrutura não preparada para visitas sistemáticas devido ao funcionamento das máquinas, coleta de dados e manutenção técnica dos equipamentos, etc. 
Nesse contexto, mais do que museu ou centro de ciência, o laboratório é mais um espaço que, quando possui intencionalidades educacionais, pode se transformar em um importante meio de diálogo com a escola básica e a população em geral. As visitas podem possibilitar a aprendizagem de estudantes e cientistas sobre a complexidade de mundo em que ambos se encontram e compreender os contextos onde cada um produz suas formas de saber e conhecimentos específicos.

Assim como nos museus de ciências, o laboratório também pode aproximar os sujeitos do conhecimento científico sem, no entanto, substituir o papel da escola. Como cita Jorge Wagnesberg (2004):

Enseñar, formar, informar, proteger el patrimonio, divulgar son otras vocaciones del museo, aunque ninguna de ellas es prioritaria. Lo prioritario es crear una diferencia entre el antes y el después de la visita que cambie la actitud ante todas esas actividades y otras relacionadas con la ciencia como: viajar, pasear por una librería, preguntar en clase, seleccionar canales de televisión, etc. El museo provee más perguntas que respuestas (WAGNESBERG, 2004:257).

Wagnesberg (2004) ainda defende que um museu deve se basear nas emoções dos visitantes e não em seus conhecimentos prévios. Segundo o autor, nenhuma boa exposição substitui o livro, a aula ou um documentário; o papel do museu é de promover trocas sociais, promover o interesse pela ciência e ter a capacidade de estimular o público a querer compreender as emoções do conhecimento científico assim como os cientistas as sentem. Essa intenção também pode ser esperada em visitas aos laboratórios sem, no entanto, descaracterizar o papel do conhecimento específico atrelado ao acelerador Pelletron. Propomos, assim, inserir objetivos mais amplos do ensino de ciências nesses espaços.

Para que esses objetivos sejam efetivos é necessário que se promova, na interação ente os cientistas e o público, uma reflexão que se inicie a partir dos idealizadores das visitas. Esse saber de mediação se refere ao conhecimento daqueles que as pensam para além do conhecimento científico. Nesse contexto, não pode se confundir com o papel do cientista, que é o sujeito que faz ciência e também a divulga para o público. Assim, a mediação se dá por esses indivíduos ao se 
promoverem atividades, situações de diálogo e materiais, que sejam capazes de dar sentido, junto com os cientistas, aos visitantes e, ao mesmo tempo, possibilitar que esses profissionais transitem pelo seu ambiente de trabalho de forma a respeitar sua história, sua linguagem e sua postura com o público.

Desse modo, ao se posicionar como um possível espaço da promoção da educação científica, o laboratório científico não pode deixar de lado todas as dimensões que envolvem o contexto dos museus e suas formas de mediação. Essas reflexões, por outro lado, também não podem deixar de caracterizar as dificuldades do contexto onde ocorrem. A mediação no laboratório deve visar construir interesses e saberes que possuam a finalidade de arquitetar um conhecimento mais amplo sobre o sentido da ciência. Essa dimensão não traz uma aprendizagem da ciência per se, mas evoca um aprofundamento contextualizado de determinados conteúdos e, ao mesmo tempo, abrange o sentido de conhecer a ciência.

Esses saberes de mediação são, em sua maioria, conhecimentos necessários para que as mediações diretas criem vínculos entre aquilo que é apresentado e o público. Apesar de serem direcionados para o aprimoramento dos sujeitos que mediam em espaços não formais, consideramos que tais saberes também podem ser pensados nos contextos das mediações indiretas e na gestão do projeto e da formação. Tais saberes, por sua vez, também podem ser contemplados no contexto do laboratório científico, quando tal ambiente se propõe a refletir sobre a inserção do conhecimento educacional nesses espaços.

Em suma, procuramos, nesse capítulo, compreender como os laboratórios científicos são compreendidos na pesquisa social, atrelando os conhecimentos trazidos dos estudos de espaços não formais, para fundamentar nossa posição acerca do papel desses ambientes como educacionais.

Assim, é importante que se deva procurar defender a posição desses laboratórios compreendendo suas especificidades, como salientado nesse capítulo, e, portanto, os reconhecendo como outra forma de promover, em dimensões que consideramos mais amplas, o conhecimento científico e o diálogo entre cientistas e público. 
Portanto, as visitas em laboratórios de pesquisa não podem ser classificadas enquanto espaços: formal, não-formal ou informal; diante das regras que são especificadas dessas subáreas do ensino. Por outro lado, podem-se reconhecer as visitas ao acelerador Pelletron como um objeto com suas especificidades que não podem ser desconsideradas enquanto tema de pesquisa.

Assim como o espaço não-formal, o espaço do laboratório pode ser trabalhado em conjunto ao espaço formal, respeitando as especificidades de cada um e proporcionando aos estudantes uma aprendizagem que subverta a visão tradicional do conhecimento. Esse tipo de educação também deve permear a interação no laboratório onde haja uma constante integração entre instituições de ensino e outros setores da sociedade, para que não seja apenas de responsabilidade da escola, a formação dos indivíduos que nela entram. As possibilidades e formas criadoras de se aprender os conteúdos científicos, então, podem ser ampliadas para outros contextos e ambientes, como defendem seus pesquisadores.

Com isso, o trabalho de divulgação científica nesses espaços ganha objetivos bastante específicos em relação às outras formas de divulgação. Mais do que se limitar à exposição dessas máquinas, este trabalho busca trazer uma possível cooperação entre escola e instituição de pesquisa através de trocas de conhecimentos. Busca salientar o papel da ciência enquanto objeto em transformação, sua relação interdisciplinar com outras áreas do conhecimento e suas implicações sociais.

Essa postura, também, reflete a importância dada na interação com os cientistas e os laboratórios, possibilitando novas perspectivas sobre o contexto de produção do conhecimento científico. Assim, o acelerador Pelletron pode buscar, através de uma reflexão pedagógica e de diálogo com a comunidade escolar, promover uma educação científica para os estudantes, que possa motivar uma visão mais ampla sobre o conhecimento científico e trazer, para o laboratório, interações que gerem reflexões sobre as práticas pedagógicas nesses espaços, ampliando o conhecimento sobre a escola, e consequentemente, melhorando continuamente as estratégias das visitas ao longo dessas trocas. 
Nesse sentido, os laboratórios científicos, pautados nesse universo educacional e inseridos como espaços de promoção da educação científica, se mostram como outro espaço de educação, cujo objetivo é apresentar em contextos mais amplos, o conhecimento científico. Para tanto, olhar para esses ambientes requer a reflexão sobre os objetivos e as possíveis formas de se alcançá-los, através da mediação entre cientistas e público, das atividades e situações, geradas sob a dimensão educacional esperada. 


\title{
Capítulo 4
}

\section{Perspectivas de atuação pedagógica nos laboratórios científicos}

\author{
叉or um mundo onde sejamos socialmente \\ iguais, humanamente diferentes \\ e totalmente livres \\ Qosa Euxemburgo
}

Olhar para o laboratório científico como espaço de formação científica mostrou-se capaz de trazer dimensões do conhecimento que, atreladas ao contexto educacional escolar, podem possibilitar uma visão mais abrangente da ciência. No entanto, para que isso ocorra, também é necessária a interlocução com a pesquisa educacional, no sentido de que as ideias desse campo possibilitem traçar caminhos cujos objetivos sejam coincidentes em promover uma educação científica efetiva.

Assim, o processo de construção do reconhecimento do acelerador Pelletron como campo educacional, na área do ensino de ciências, trouxe algumas dimensões acerca do conceito de espaços não formais como instrumento de promoção da ciência através dos museus e centros científicos. Essa postura nos levou a compreender como os laboratórios podem se situar, ao tomar emprestados determinados elementos, que o caracterizam como ambiente capaz de promover a educação científica.

No entanto, devido às singularidades envolvidas nesses espaços de produção da ciência, foi necessário o aprofundamento das questões sobre o entendimento do laboratório no campo da sociologia e na formação continuada de professores; que juntos trouxeram uma perspectiva mais fundamentada sobre as distinções que podem ser compreendidas nesses ambientes em relação aos espaços de divulgação científica.

Buscaremos, nas próximas seções, fazer um panorama das discussões sobre Alfabetização Científica e o movimento CTS, com o intuito de trazer novas perspectivas de atuação nas visitas ao acelerador. Elas correspondem a ampliar a 
atuação desses espaços para outras instâncias do saber sobre ciência e possibilitar que novas potencialidades sejam percebidas através de tais reflexões.

\subsection{Reconhecendo os objetivos/processos da Alfabetização Científica e Tecnológica.}

As múltiplas definições do conceito de alfabetização lançaram na área de pesquisa em ensino de ciências diversas concepções do que seria tal termo, do ponto de vista da educação científica. Mesmo sem um consenso no campo da educação, vêem-se diversos trabalhos que enfocam o tema e o utilizam de formas diferentes em relação ao seu entendimento, sendo algumas vezes a alfabetização científica relatada como processo e em outras, como finalidade. No entanto, uma convicção é partilhada por esses pesquisadores quanto à necessidade de que nãocientistas que vivem em uma cultura científica e tecnologicamente complexa deveriam saber um pouco sobre ciência (DURANT, 1993:14). E isso implica, segundo alguns autores, em dar sentido à aprendizagem dos conteúdos científicos e não somente demonstrar os produtos finais, como podem ocorrer nos processos de vulgarização ou disseminação científica (GERMANO \& KULESKA, 2007).

Deste modo, Isabel Martins (2008) critica a metáfora (alfabetização) assumida nos trabalhos em pesquisas em ensino de ciências, ao se apropriarem de um conceito linguístico e que, segundo a autora, pode ser um fator de conclusões equivocadas e, por vezes, errôneas de suas intenções. Assim, a autora buscando uma análise mais aprofundada de seus termos a fim de questionar a validade do conceito de alfabetização no campo da educação científica.

Martins (2008) aborda a questão propondo uma primeira distinção necessária do campo da linguagem entre: alfabetização, alfabetismo e letramento. Portanto, uma primeira diferenciação é compreender como o conceito de alfabetização é tratado dentro de sua área de origem e como as características entre os termos acima, levantados por Martins, são compreendidos. Ou seja, como processo (alfabetização) e como estado ou condição assumida pelo sujeito de aprender a ler e escrever (alfabetismo e letramento). 
Do ponto de vista da compreensão do conceito de alfabetização, segundo suas áreas de origem, psicologia, linguística e pedagogia; Magda Soares (2003) propõe uma definição acerca da etimologia da palavra que remete a uma aquisição do código escrito, das habilidades de leitura e escrita (SOARES, 2003:15). Isso implica que $\mathrm{o}$ ato de operar e decodificar um código já se designaria, em um primeiro momento no que se poderia entender como uma alfabetização, seja no âmbito da leitura ou escrita, sem orientar o sujeito no que diz respeito a valores éticos e morais, relações sociais e econômicas que estão imersas em tal processo, seja no âmbito político, onde o ato de compreender o mundo criticamente é relegado ao segundo plano.

Longe de entender tal processo como remete seu estudo etimológico e ao, mesmo tempo, longe de precisar um método que indique artifícios para a aquisição dos códigos da língua, o processo de alfabetização ainda sofre com as dificuldades de compreender se a aprendizagem de tais códigos está associada a algo a ser ensinado pelo professor ou a algo que é aprendido pelo aluno. Para a autora, trabalhos nesse campo advogam por uma alfabetização que se desvincule de um método de ensinar, propondo uma visão de mundo onde o sujeito aprende a ler e a escrever, ou seja, não seria o método que ensina a ler e a escrever (SOARES, 2003:90). Por este motivo, a alfabetização pode ser considerada um termo inserido em uma área multifacetada, sendo, no campo das teorias psicológicas e psicolinguísticas, um processo reconhecido pela natureza sociolingüística, que compreende um processo de transferência da sequência temporal da fala para a sequência espaço-direcional da escrita, e de transferência da forma sonora da fala para a forma gráfica da escrita (SOARES, 2003:21). Para a autora, a natureza complexa do processo de alfabetização só tem evidenciado a forma parcial de enfrentar os problemas acerca da própria identificação dos pré-requisitos necessários para o sujeito se alfabetizar. Ela alerta para a necessidade de ampliar a visão do processo, remetendo aos requisitos que antecedem à alfabetização.

Para Soares, é fundamental, para o sucesso no processo de alfabetização, que seja levado em conta o conhecimento que antecede a ação pedagógica, contemplando os conhecimentos necessários para que se promova um maior aproveitamento por parte dos estudantes. Em decorrência deste caminho, a autora 
designa ao alfabetizado, ou seja, àquele que passou por este processo de maneira satisfatória, o papel de utilizar de suas prerrogativas da leitura e escrita para participar e contribuir para o desenvolvimento de uma sociedade enquanto indivíduo letrado, buscando questionamentos em suas bases políticas, econômicas e sociais, através de uma postura crítica, possibilitando assim uma transformação no meio em que atua.

Deste modo, chegamos à segunda questão que emerge dos trabalhos em ensino de ciências. Ao compreender a alfabetização como processo, que sentido teria o termo letramento? Para Martins (2008), a diferenciação entre alfabetização e letramento se dá fundamentalmente, na compreensão entre diferentes concepções de escola. A alfabetização científica seria o domínio de uma linguagem científica, ou seja, a aprendizagem dos códigos relacionados aos conceitos - entendidos por fórmulas, tabelas e gráficos - e seus significados. Por outro lado, o letramento científico estaria associado ao uso social da aprendizagem para uma visão crítica do mundo. Assim, segundo a autora, ao empregar o termo letramento, busca-se enfatizar a função social da educação científica contrapondo-se ao restrito significado de alfabetização escolar (MARTINS, 2008).

Portanto, se o entendimento do conceito de alfabetização provir do campo da linguagem, ele não pode apenas ser considerado como recurso de aprendizagem de uma língua - visto que ela não pode ser só vocabulário e gramática. A linguagem é um sistema de recursos para construir significados (LEMKE, 1993:12) onde o letramento teria o papel de prover um processo que tem como intuito maior a contextualização e a inserção crítica de mundo. Logo, podemos compreender a alfabetização como um processo cuja finalidade esperada é que seus indivíduos sejam capazes de participar das decisões sociais, políticas e econômicas, utilizando das habilidades de escrita e leitura na procura por uma postura crítica que se faz no diálogo e na aprendizagem constante de mundo.

No campo da educação científica, a expressão "alfabetização científica" ganhou força em meados dos anos 80 , quando surgiu uma grande preocupação sobre quais conteúdos científicos seriam necessários para que um sujeito fosse considerado alfabetizado cientificamente. Trabalhos que listavam diversos 
conteúdos sobre biologia, física e química foram apresentados como instrumentos de avaliação sobre o grau de alfabetização dos estudantes americanos (DURANT, 1993:14).

Próxima da concepção de educação formal, a alfabetização científica associada à familiarização dos conteúdos da ciência está inevitavelmente associada aos currículos escolares. Nela a aquisição dos conteúdos científicos é listada através de metas a serem cumpridas pelos estudantes a fim de serem detentores de uma grande quantidade de conteúdos escolares, associados aos seus modelos e esquemas interpretativos da ciência.

Em repostas a este tipo de abordagem da alfabetização científica, diversos trabalhos apontam para a necessidade de se avaliar em que medida a aquisição de fatos científicos seriam a mesma coisa que compreensão científica (DURANT, 1993:15). Jon Miller propõe três componentes que uma pessoa deveria ter para ser alfabetizado cientificamente: a) um vocabulário básico de termos científicos e tecnológicos; b) uma compreensão dos processos ou dos métodos científicos para testar nossos modelos de realidade e c) uma compreensão do impacto da ciência e da tecnologia sobre a sociedade (DURANT, 1993:16). Apesar do esforço de alguns pesquisadores que partilhavam dessas ideias, a crítica considerava que elas não constituíam uma representação verdadeira e útil do processo de investigação científica.

A principal negativa que ficaria demarcada para os autores era a da não limitação entre ciência e pseudociência, o que omitiria todo o processo de escolhas e publicações, a descrição do trabalho, as convenções rigorosas, etc. associadas ao fazer científico. Assim, para entender a ciência efetivamente atual, os estudiosos defendem, além do conhecimento, específico, a percepção sobre o modo pelo qual o sistema social da ciência realmente funciona para divulgar o que é usualmente conhecimento confiável a respeito do mundo natural (DURANT, 1993:25).

Os trabalhos apresentados por Durant trazem uma breve contextualização da visão que proliferou dentro de educação, onde a alfabetização científica é compreendida sob o olhar diferente de sua matriz epistemológica, sendo discutida como uma finalidade a ser alcançada e não um processo em busca de métodos - se 
é que se necessite de um - ou o interesse na diversidade de contextos sociais, culturais e históricos em que se dão estes processos. Portanto, se a compreensão do conceito de alfabetização científica seja a capacidade de ler, compreender e expressar opinião, segundo Germano e Kulesza (2006), deveria partir do pressuposto de que o indivíduo já tenha interagido com a educação formal, e dessa forma, dominado o código escrito.

Portanto, a alfabetização científica implica em muitas concepções que se incorporam em determinadas situações, com um caráter polêmico e difuso em sua interpretação (DÍAZ et al, 2003). Em uma tentativa de revisão, Laugksch (2000) enumera alguns fatores para os seus diversos pressupostos, perspectivas, concepções e significados. Aponta diferenças relacionadas a cinco situações: a) diferentes grupos de interesses na alfabetização científica e tecnológica (comunidade de especialistas, cientistas sociais, especialistas em educação científica, divulgadores, etc.); b) diferentes definições conceituais do termo; c) natureza absoluta ou relativa do termo; d) as finalidades e variedades de propósitos que se perseguem e e) as diversas maneiras de se medir um processo ou sujeito alfabetizado, que em parte são consequência das anteriores (DÍAZ, 2003).

Em suma, a diversidade das dificuldades apontadas para o que se entende pelo tema demanda, ainda hoje, um grande número de estudos que esbarram no próprio entendimento proveniente da área de origem e prolifera, fazendo-se ampliar o leque de discussões sobre o tema também em âmbitos como o da educação científica. É neste sentido que a alfabetização científica e tecnológica é inserida no campo da educação por Gérard Fourez. Seus trabalhos sobre a relação entre movimento CTS (Ciência - Tecnologia - Sociedade) e a Alfabetização Científica e Tecnológica (ACT) foram muito aceitos na pesquisa nacional e largamente estudados pelos grupos que se interessam pelo tema. Sua primeira preocupação é deixar clara a importância de diferenciar essas duas reflexões pedagógicas. Para o autor, enquanto a ACT fala em uma promoção da cultura científica e tecnológica, o movimento CTS busca questionar o lugar da ciência e das tecnologias na sociedade, ainda que implicitamente (FOUREZ, 1994:18). 
O cerne da questão, então, é compreender a proposta de Fourez em agregar alfabetização científica e alfabetização tecnológica. As diferenças entre os dois termos, segundo seus teóricos, seriam, em resumo, seus objetivos. Enquanto a ciência buscaria o conhecimento, a tecnologia a ação. Na ciência se aplica o método da investigação científica, em contrapartida à tecnologia, que se importa com uma série de outros fatores como estética, segurança, funcionalidade, etc. (FOUREZ, 1994:45). Do ponto de vista epistemológico, a ciência e a tecnologia, seriam distintas pelo seu local de aplicação. A ciência se colocaria menos como uma investigação pela verdade por ela mesma, mas como um método de invenção de modelos, reduzidos aos laboratórios, onde a busca científica estaria atrelada ao seu lugar material e culturalmente situado. Para o autor, o que estaria em jogo nessas definições são os interesses de diversas instituições sobre as finalidades da educação científica.

Para Fourez, a superação de tal pensamento deve combater a ideia de uma visão da ciência neutra e sem a consciência de suas finalidades e de seu caráter contextualizado. Assim, uma educação justa está empenhada com a valorização dos compromissos humanos ligados à produção do saber. Portanto, o saber, seja científico ou tecnológico, deve ser ensinado como uma produção humana, por e para seres humanos - saberes sempre com uma finalidade, interessados em um sentido mais profundo (FOUREZ, 1994:57). Isto implicaria, para o autor, em apresentar uma ciência que coloque em evidência o valor de caráter humano e cultural dela própria e das tecnologias. A postura defendida pelo autor cria uma nova junção: a alfabetização científica - tecnológica.

Em outras palavras, o autor considera um indivíduo alfabetizado científica e tecnologicamente quando seus saberes proporcionarem uma certa autonomia para possibilitar negociar decisões frente a questões sociais ou científicas, uma capacidade de se comunicar para encontrar maneiras de defender suas decisões e um domínio e responsabilidade frente a situações do cotidiano (FOUREZ, 1994:62). A partir desses pressupostos, o autor, sugere como método para o processo de alfabetização científica, o desenvolvimento de projetos escolares na escola básica. 
Críticas mais recentes sobre o tema enfatizam que alguns estudiosos procuram adequar os conhecimentos científicos, em uma sociedade participativa, com seleção de conteúdos complexos, em um panorama irreal de tempo, qualidade de ensino e contexto social (FENSHAM, 2002). No entanto, para Praia, Gil-Pérez e Vilches (2007) a complexidade dos conteúdos abordados não impede a participação ativa da sociedade em tomadas de decisões que acarretem impactos sobre suas vidas. Nesse sentido, os autores concordam sobre a complexidade dos temas, mas defendem que os conteúdos mínimos para uma formação científica tornam compreensíveis as soluções, problemas e as consequências da utilização da ciência. Isto implica em uma alfabetização científica que considere não apenas altas hierarquias da sociedade, mas em uma defesa da igualdade de direitos por uma educação igualitária.

No Brasil, a busca por essa inclusão social levou Chassot (2003) a compreender a alfabetização científica como uma linguagem da ciência que proporcionaria o entendimento de sua escrita, em uma língua que conhecemos, e consequentemente como a linguagem na qual está (sendo) escrita a natureza (CHASSOT, 2003). Isso significaria a possibilidade de dispor de conhecimentos científicos e tecnológicos necessários para se desenvolver na vida diária, ajudar a resolver os problemas e as necessidades de saúde e sobrevivência básica, tomar consciência das complexas relações entre ciência e sociedade (FURIÓ apud CHASSOT, 2003). Dentro deste panorama, Chassot (2000) ainda defende a necessidade de considerar

a alfabetização científica como o conjunto de conhecimentos que facilitariam aos homens e mulheres fazer uma leitura do mundo onde vivem. Amplio mais a importância ou as exigências de uma alfabetização científica. Assim como exige-se que os alfabetizados em línguas materna sejam cidadãs e cidadãos críticos, em oposição, por exemplo, àqueles que Bertrolt Brecht classifica como analfabetos políticos, seria desejável que os alfabetizados cientificamente não apenas tivessem facilitada a leitura do mundo em que vivem, mas entendessem as necessidades de transformá-lo, e transformá-lo para melhor (CHASSOT, 2000:34). 
Em trabalhos atuais sobre alfabetização científica e tecnológica, encontramse diversas ideias sobre o conceito, como aquisição de conhecimentos e vocabulários científicos, associado a diferentes contextos: a um contexto transformador de mundo (NASCIMENTO et. al., 2006; RICHETTI \& ALVES FILHO, 2009; AIRES \& LAMBACH, 2010); no contexto onde os saberes científicos estão associados a tomadas de decisões frente a assuntos que se relacionam com a ciência (NEHRING et. al., 2002; MILARÉ \& ALVEZ FILHO, 2010); na inscrição onde traços, equipamentos, registros dão visibilidade ao conhecimento (OLIVEIRA, 2010) e como apropriação de esquemas conceituais e métodos processuais que permitem uma contextualização e compreensão dos significados científicos (LORENZETTI \& DELIZOICOV, 2001).

Dentre todas as definições aqui apresentadas, talvez a mais emblemática seja a perspectiva da alfabetização científica proposta por Auler e Delizoicov (2001). Os autores discutem as concepções de ciência que influenciam na prática de uma educação científica unilateral, banalizada através da mitificação científica, da perspectiva salvacionista da ciência-tecnologia e seu determinismo tecnológico, acarretando em uma visão de ciência pobre e reducionista.

Os autores, através de um referencial freiriano, procuram uma alfabetização científico-tecnológica ampliada como a busca da compreensão sobre as interações entre Ciência-Tecnologia-Sociedade. Em outros termos, o ensino de conceitos associado ao desvelamento de mitos vinculados à CT (AULER \& DELIZOICOV, 2001). Auler (2003) afirma, ainda, que a alfabetização ampliada deve propiciar uma leitura crítica de mundo e enfatiza a relação direta do desenvolvimento científicotecnológico. Essa percepção do sentido da alfabetização científica traz outra demanda à discussão geral que está relacionada ao fato reconhecer o termo como uma aquisição dos conceitos da ciência, atrelada ao pensamento crítico sobre o que tais conceitos são capazes de desmistificar, permitindo ampliar a visão de mundo.

Em crítica a algumas dessas percepções, a ideia do letramento científico toma forma de aquisição de um conhecimento científico mais abrangente, cuja dimensão social da ciência ganha relevância no contexto da aprendizagem. Essa são, para Martins (2010), as maneiras pelas quais devem perpassar as intenções de 
se promover a educação científica. Assim, mais do que objetivar a alfabetização científica dos estudantes, ou seja, a aquisição de informações e a formação de conceitos, busca-se promover um conhecimento que leve em conta os contextos culturais daqueles que aprendem e possibilitem aprendizagens capazes de promover a satisfação emocional, afetiva e intelectual (MARTINS, 2010:380).

Nesse contexto, para a autora, aprender a "linguagem da ciência" é diferente de ser alfabetizado cientificamente, pois a linguagem científica evoca aprender os contextos, as forma pelas quais se dá sentido à ciência.

(...) se considerarmos a linguagem da ciência como uma reconstrução semiótica da experiência humana, algumas de suas características, como alta densidade léxica e terminologia técnica, adquirem um novo sentido relacionado à natureza do conhecimento científico e aos seus processos sociais de construção. Além disso, tornar-se proficiente nessa linguagem envolve compreender as práticas sociais de produção e validação de conhecimentos, típicas dos laboratórios e recontextualizadas em espaços educativos, formais e não formais (MARTINS, 2010: 368).

É a partir dessas reflexões que podem surgir uma postura crítica e capaz de mudança social, atrelando esse conhecimento adquiridos a uma maneira menos ingênua de olhar para o mundo. Esse estar letrado cientificamente também perpassa compreender os aspectos mais amplos da ciência, relacionados à linguagem científica, como forma de olhar para o todo em suas dimensões sociais e afetivas, que de certa forma, evocam o sentido de se fazer ciência.

Em suma, partindo do pressuposto da alfabetização científica, a compreensão de conceitos científicos é parte desse processo, sendo que só poderá atingir sua finalidade (mesmo que não em sua integralidade) quando entendermos essa compreensão como pré-requisito, fundamental para uma contextualização sobre o saber que ultrapasse o reconhecimento de conceitos científicos para uma postura ativa.

Isso implica em incluir da compreensão da finalidade dos mesmos, podendo então, chegar o mais próximo daquilo que almejamos na educação científica, ou 
seja, de que os estudantes possam olhar a ciência em seus mais variados aspectos, sua produção intelectual como construção humana e a insubordinação do homem ante as certezas do discurso autoritário científico.

\subsection{Reconhecendo os objetivos do Movimento CTS.}

O movimento CTS sempre teve forte apelo crítico em questões acerca da relação ciência, tecnologia e sociedade. Suas principais fontes de contestações emergiram do contexto social turbulento na década de 70 , onde intelectuais começaram a questionar o papel da Ciência e da Tecnologia (C\&T) como promotoras do bem estar da humanidade e sua neutralidade (AULER \& BAZZO, 2001; SANTOS \& MORTIMER, 2002; STRIEDER, 2008). Imbuídos de levar essas discussões para o âmbito da escola básica; estudiosos do campo da educação iniciaram propostas que pudessem nortear as escolhas dos professores e pesquisadores para um ensino que proporcionasse uma visão crítica de mundo. Este tipo de postura confrontava o papel da ciência, tecnologia e sociedade no currículo tradicional de ciências, onde sua função era majoritariamente enfatizar os conteúdos científicos pautados em uma postura de neutralidade, dando à tecnologia e à sociedade papéis secundários nesse processo.

Em 1982, esses pesquisadores num encontro dentro da IOSTE (Internacional Organization for Science and Technology Education), provavelmente influenciados pelas ideias de John Ziman ${ }^{4}$, escolheriam a tríade CTS como lema para a proposta defendida por eles, onde o desenvolvimento curricular deveria ser baseado nas interações entre a ciência, seus aspectos tecnológicos e sociais, que consequentemente influenciavam e modificavam o mundo no seu entorno (AIKENHEAD, 2003).

Considerado de origem binacional, o movimento sofreu uma forte influência, de um lado, da tradição européia ou acadêmica, que buscava compreender a ciência em seu aspecto teórico e o contexto da sociedade neste processo, e, do outro, da

\footnotetext{
4 John Ziman publicou em 1980 publicou o livro "Teaching and learning about science and society", pela editora Cambridge University Press, que se tornou leitura obrigatória entre os educadores de ciências (Aickenhead, 2003; Santos, 2001)
} 
tradição americana ou social, que priorizava questões de cunho social voltadas para uma prática efetiva de reivindicações, preocupadas com as consequências sociais e ambientais que a C\&T acarretavam. Atualmente, superada essa separação na origem do movimento, é compreendida como núcleo da perspectiva CTS o rechaço da neutralidade científica, a crítica à concepção tecnológica como ciência neutra e a promoção pública de tomada decisão em questões sociais daqueles que nela participam.

No entanto, apesar de apresentarem uma ideia central comum, diversos programas que desenvolvem estudos nessa linha podem ser divididos em três direções ou campos, como sugere Garcia et.al. (1996): o campo investigativo, o campo das políticas públicas e o campo da educação. O primeiro enfoque prioriza o estudo dos conceitos associados à tríade CTS, dando ênfase para o estudo contextualizado em sua dimensão social. Isto implica em olhar para ciência e tecnologia analisando a natureza de sua participação e relação com as questões sociais. O segundo enfoque procura enfatizar o caráter de participação social nas questões de ciência e tecnologia, centrando-se nas relações C\&T e suas consequências sociais. Finalmente, no campo da educação, busca-se no ensino de ciências, que se evoque uma formação crítica e contextualizada, promovendo a participação da sociedade em questões de cunho científico-tecnológico.

Os campos acima citados por Garcia ganharam força no Brasil, em especial na área de pesquisa em ensino de ciências, em meados de 1990, com a publicação de diversos trabalhos considerados pioneiros na área, alem de suas presenças em documentos legais (STRIEDER, 2008).

No campo da investigação em ensino de ciências, Santos e Mortimer (2002) justificam a perspectiva CTS como ênfase curricular, pois um estudo das aplicações de ciência e tecnologia, sem explorar as suas dimensões sociais, pode propiciar uma falsa ilusão de que o aluno compreende o que é ciência e tecnologia (SANTOS \& MORTIMER, 2002:12). Os autores prosseguem afirmando que esse tipo de abordagem apresenta uma visão alienada da natureza desses conhecimentos, sem mostrar outros valores que estão envolvidos no fazer científico e tecnológico. 
No entanto, cabe salientar que o tema CTS procedendo de diferentes pesquisadores - influenciados pelas circunstâncias e propósitos adotados - ainda hoje não goza de um consenso em sua definição. Segundo Aikenhead (2003), de uma maneira geral, o contexto cultural é tema recorrente tanto do ponto de vista do surgimento do movimento como de sua evolução ao longo do tempo. A cultura dialoga com o movimento CTS através da visão de um modelo de currículo de abordagem intercultural, como cita Santos (2001). Este tipo de perspectiva curricular cultural foca as diversas concepções de mundo dos sujeitos envolvidos no processo pedagógico.

Além do currículo acima citado, Santos (2001) agrupa três grandes tendências de sentido CTS que dão ênfase para ciência ou tecnologia ou sociedade, este último onde o currículo intercultural se reconheceria. A primeira perspectiva, cujo enfoque científico é mais proeminente, procura mostrar a relevância da ciência na tecnologia e sociedade. Todavia, na seleção desses conceitos, desvalorizam a tradição da conservação de conteúdos canônicos, segundo uma orientação acadêmica pura, em favor, da valorização de tópicos com utilidade social elou valor humanísticos (SANTOS, 2001:55).

Currículos pautados na perspectiva da tecnologia como ciência aplicada, buscam ao salientar os aspectos científicos, demonstrar os aparatos tecnológicos como resultado do conhecimento científico aplicado a objetos que em termos gerais, podem ser compreendidos como uma resposta a demanda sociais. No entanto, currículos como este, subestimam

as grandes complexidades do processo, descrições curriculares de tecnologia como ciência aplicada tendem a dar uma imagem de linearidade e de superficialidade que não tem em conta que os conhecimentos científico e tecnológico, apesar das suas relações, diferem na forma e na substancia e que, portanto, "os que estão empenhados em tarefas tecnológicas têm muitas vezes de retrabalhar o conhecimento científico a fim de o poderem usar" (LAYTON, 1993: 13). De fato, mesmo a conversão de aparelhos à escala laboratorial em aparelhos à escala comercial não é nada direta nem simples. (Santos, 2001: 58) 
Os currículos em que a tecnologia é a primeira referencia defendem a visão dos instrumentos tecnológicos como os grandes impulsionadores da ciência. É fato que atualmente, grandes laboratórios de pesquisa são fundamentais para o desenvolvimento das atividades científicas. No entanto, a crítica remete a esse tipo de currículo em que a ciência teria uma dependência sistemática desses instrumentos. Segundo Santos patenteia o perigo de fazer esquecer que os alunos vivem num mundo cada vez mais moldado pelo conhecimento científico e que 0 conhecimento tecnológico, embora possa e deva contribuir para cruzar fronteiras com aquele conhecimento e para elucidar a construção do conhecimento prático, não pode constituir uma alternativa 'tout court' ao conhecimento científico (SANTOS, 2001:74).

$\mathrm{Na}$ perspectiva curricular CTS com ênfase na sociedade, geralmente pautados nas propostas de estudos sobre alfabetização científica e tecnológica, que enfatizam a necessidade de se utilizar tópicos de vida cotidiana do estudante para a compreensão de conteúdos escolares (SANTOS, 2001). Esse tipo de proposta usa da ciência e tecnologia como meio para abordagens cuja relevância social e cultural seja atribuída à aprendizagem de conteúdos científicos. Para seus críticos, essa maneira de encarar o currículo seria uma forma de enfatizar demasiadamente questões de cunho social, deixando em segundo plano a aprendizagem dos conceitos científicos - isto remeteria a um outro extremo dos currículos que se pautam somente em aspectos científicos deixando como pano de fundo questões tecnológicas e sociais.

Strieder (2008) enfatiza que as diversidades de enfoques CTS se refletem em propostas e pressupostos que não apresentam, um método ou técnica de ensino que seja considerado específico do movimento. Neste contexto, a autora constata que não há um consenso no que diz respeito a instrumentos concretos para inserir essas discussões nos espaços escolares, ou seja, sobre como (grifo do autor) "alcançar" esses objetivos, quais elementos e estratégias precisam ser utilizados e/ou priorizados (STRIEDER, 2008:40). A autora ainda chama atenção que a questão vai além da diversidade das propostas e atinge o âmbito dos pressupostos educacionais que seus pesquisadores/autores abordam em seus projetos. Neste contexto, Strieder (2008) busca a articulação com o referencial educacional baseado 
nas ideias de Paulo Freire (1987) como maneira de delimitar objetivos e estratégias para propostas articuladas ao CTS. Baseada em uma análise de trabalhos na perspectiva CTS, a autora propõe outro olhar para a inserção nos espaços formais, através uma releitura da investigação temática proposta por Delizoicov, Angotti e Pernambuco (2002).

Como proposta para superar essa dicotomia das perspectivas freiriana e CTS, a autora propõe uma intervenção pontual da abordagem CTS no currículo tradicional de ciências, onde discussões que não fazem parte de tal currículo estivessem associadas aos conteúdos já existentes na escola, sendo compreendidos como complementares ou paralelos. No entanto, Strieder salienta que esse tipo de abordagem ou método não pode ignorar a realidade do aluno, devendo partir da mesma, utilizando conhecimentos científicos e tecnológicos para contribuir na constituição da formação transformadora de mundo dos estudantes. Contudo, a autora enfatiza que essa intervenção pontual não é suficiente para que os estudantes passem a olhar para o desenvolvimento científico-tecnológico de forma crítica (STRIEDER, 2008:67); mas o ideal desses pressupostos, quando, imersos no contexto educacional, pode ser um motivador na medida em que o aprendizado passa a ter, para o aluno, um novo significado (STRIEDER, 2008:67).

Para Maria Eduarda V. M. dos Santos (2005), essa busca pela construção de uma cidadania cultural, crítica e ativa demanda, como estratégia epistemológica, ancorar os conhecimentos sobre ciência em perspectivas CTS eticamente orientadas (SANTOS; 2005). O que a autora propõe é o entendimento das transformações científicas como matrizes de um contexto social e tecnológico apoiado em rupturas das convenções da ciência e da cidadania moderna.

Nessa perspectiva, a proposta aqui apresentada busca através das visitas aos laboratórios de pesquisa, alicerçar as escolhas e tema possíveis de serem trabalhados através da perspectiva CTS. Assim, os conceitos científicos e sua produção intelectual, o aparato tecnológico que ampara essas pesquisas, o desenvolvimento de materiais e as questões acerca do bem-estar que eles produzem, são todos os elementos que devem ser apresentados e discutidos nas visitas. 
Para tanto, as ideias do movimento CTS que evocam uma perspectiva de formação crítica de mundo, onde a relação desses conceitos deve ser compreendida de forma a envolver a atuação da ciência, tecnologia e sociedade, trazem novas possibilidades de discutir acerca do fazer científico. Tais perspectivas evocam, nas interações entre os laboratórios científicos e o público, uma grande carga de responsabilidade, que transcende o discurso da importância intelectual científica e neutra, para uma possibilidade de diálogo crítico do ato de produzir ciência em seus aspectos políticos, éticos, morais e humanos.

Em síntese, procuramos nesse capítulo, discutir o papel da alfabetização científica e do movimento CTS, como reflexões para ajudar-nos a compreender a atuação pedagógica dos laboratórios no campo educacional. Essas possibilidades foram sendo demarcadas ao longo desse texto, através da dimensão de reconhecimento sobre os espaços não formais, os saberes de mediação necessários para que ocorra o diálogo entre os sujeitos envolvidos no processo de interação e as aproximações e especificidades desses espaços de produção da ciência em relação aos diferentes aportes teóricos.

Deste modo, as ideias da alfabetização científica ajudam a compreender o papel da aquisição dos conhecimentos científicos de forma mais abrangente, possibilitando reconhecer que os conceitos envolvidos nesse processo são importantes meios de compreensão sobre aspectos críticos que se queiram introduzir nesses espaços. São, portanto, elementos fundamentais para a formação científica, pois remetem a um comprometimento que envolve, de maneira balizada, uma posição acerca de assuntos sobre a ciência. Esse aspecto pode contribuir para a seleção do conhecimento a ser apresentado: ganha sentido específico discutir conceitos essenciais para o que se quer tratar. Assim, com essa referência, a apresentação de conceitos básicos se justifica apenas na medida em que possam ganhar sentido no diálogo com os visitantes. Ao contrário, não seria igualmente relevante buscar um ensino de conceitos mais amplo, com maior abrangência, já que o laboratório não se pode propor com funções equivalentes às da escola.

Em relação às visitas, o processo de aquisição desses conteúdos, que reconhecemos como função da escola, pode ser analisado sob a dimensão de 
elemento de reforço dessa obtenção, reconhecendo aspectos que envolvem a produção e a aplicação desses conhecimentos, mas apropriando-se de um assunto de forma a construir uma opinião sobre ele. Essa dimensão da alfabetização científica implica em considerar a aprendizagem dos conteúdos através de uma abordagem que possibilite subsídios para aprimorar esse saber, de forma a ampliar o conhecer sobre a ciência, e não somente, aumentar a aquisição dos conteúdos.

Essa postura, até certo ponto, também faz consonância às ideias do movimento CTS, pois reflete uma preocupação sobre as relações que são estabelecidas entre ciência, tecnologia e sociedade e de como elas influenciam as interações entre as muitas instituições que fazem parte da comunidade. Essa postura, que pode ser entendida como uma visão crítica acerca da neutralidade da ciência, visto que ela também se submete aos interesses políticos e econômicos, reformula a postura de apresentar a ciência per se.

Trazer situações que motivem os visitantes a pensar sobre essas questões e os instiguem a uma postura ativa de interlocução com os cientistas são maneiras pelas quais as ideias do movimento CTS podem ser inseridas nesse contexto. Isso poderia possibilitar ao público uma reflexão sobre a relação intrínseca entre o fazer científico, a tecnologia e as relações estabelecidas com a sociedade, que envolve os produtos desses conhecimentos e as influências sociais em sua construção. 


\title{
Metodologia de pesquisa
}

\author{
"叉rofessor, o senhor já nos ensinou tantas \\ coisas, nãa pode nos ensinar a arranjar emprego?" \\ \& ste é o doloroso dilema do professor no \$rasil \\ Alziz Xacib Ab' Osaber
}

A metodologia qualitativa, ao contrário da metodologia quantitativa, sofre de um apanhado de variáveis que nem sempre são passíveis de serem controladas. Contudo, ela pode ser pensada em conjunto com dados empíricos cuja referência a múltiplos métodos implica pensar em enfoques complementares para dar conta do todo (MARTINS \& BÓGUS, 2004). Isso remete a um trabalho que deve se desvencilhar do falso dilema de que o quantitativo e o qualitativo são instrumentos dicotômicos e, portanto, não podem ser utilizados de forma conjunta, em outras palavras, reduzindo o campo dos procedimentos e confundindo técnicas com métodos, negando sua função mediadora entre os pressupostos teóricos e estas últimas (LANDREANI, 1990).

Assim, nem sempre os dados quantitativos ou qualitativos analisados individualmente, dão conta de responder a fenômenos complexos, como os associados às pesquisas sociais. É importante compreender que na pesquisa na educação em ciências é necessária uma abordagem ampliada, que inclua os "comos", os "porquês" do processo (MARTINS \& BÓGUS, 2004). E então, os resultados obtidos podem fazer sentido em um contexto mais amplo da pesquisa.

Nessa perspectiva, são diversos os elementos da pesquisa que devem ser levados em conta no processo de coleta e análise dos dados. Em suma, suas variáveis mais relevantes como critérios de cientificidade podem ser divididas em três aspectos. O primeiro momento refere-se a questão epistemológica que explicita a visão de mundo da pesquisa e que se torna fundamental para compreensão da análise dos dados.

O segundo momento é aferido os métodos ou tipo de coletas que deverão ser analisados a posteriori. Dentre os diversos tipos de dados associados às mais 
diversas formas de coletas, estão: grupo focal, questionários, entrevistas abertas, semi-fechadas e fechadas, diários, vídeos etc, que são selecionados conforme a objetividade do trabalho, ou seja, com descrições de situações, pessoas, momentos e acontecimentos. A última etapa da pesquisa qualitativa é o método de análise de dados cujos instrumentos servirão para compreender o contexto ou caso estudado. É importante verificar que qualquer apresentação dos dados e suas análises devem trazer como elementos chaves a compreensão e o significado das informações coletadas e não as evidências (MARTINS \& BÓGUS, 2004). Esse tipo de postura evoca uma maior credibilidade ao instrumento utilizado e aos dados coletados.

Nas seções que se seguem serão apresentadas uma revisão da metodologia qualitativa e sua historicidade, incluindo os diversos tipos de análise, a fundamentação epistemológica das pesquisas em educação em ciências e os métodos de análise mais utilizados. Finalizaremos com uma apresentação dos momentos da pesquisa qualitativa que foram trabalhados nesse projeto e a intervenção que resultou na coleta de dados quantitativos para a triangulação dos dados.

\subsection{A metodologia qualitativa: uma breve discussão de seus problemas}

A pergunta que sempre inicia um trabalho em pesquisa nas ciências sociais é a sua capacidade de validar os dados através de um apanhado de informações que nem sempre dão conexões ao conteúdo estudado, assim, os resultados acabam por aparecer mais associados a um diálogo com o referencial teórico que a validação crítica do objeto analisado.

Neste sentido, a pesquisa qualitativa evoluiu muito desde seu remoto início no final do século XIX (CHIZZOTTI, 2003) e seus problemas vêm sendo largamente discutido em diversos trabalhos. Ao longo dos últimos anos - mais precisamente desde a década de 60 - que a dimensão quantitativa dos dados acabou por ser uma referência para respeitabilidade dos resultados, enquanto a dimensão qualitativa seria uma forma abstrata e política (lê-se que a postura do pesquisador não seria isenta de julgamento de valor) de se fazer pesquisa, esse tema gerou grandes discussões nos EUA e nos países europeus. 
No Brasil, a pesquisa qualitativa iniciaria sua diversidade de enfoques dentro da Universidade de São Paulo em 1959, com Florestan Fernandes e Roger Bastide ao realizaram uma pesquisa pautada em diferentes tipos de métodos, trazendo pela primeira vez, para um ambiente comum, um grupo de pesquisados para debateram o tema estudado (MARTINS, 2004).

No entanto, ainda no exterior, emergiam novas críticas de não cientificidade da pesquisa qualitativa sinaliza alguns critérios que buscavam defender a posição dos dados qualitativos fundamentados. Lincoln e Guba, em 1985, sugeriram que a construção da validade e legitimidade da pesquisa qualitativa deveria passar por quatro momentos: a) credibilidade; b) transferibilidade; c) consistência e d) confirmabilidade (FISHER, 2006).

Além dos critérios de legitimidade, um problema que ainda permeia os estudos acadêmicos nas ciências sociais é a preocupação com a questão ética; que passou a ter papel fundamental na pesquisa qualitativa ao final dos anos 60 , quando as universidades americanas passaram a realizar este tipo de pesquisa para empresas privadas. Theodor Adorno que participara do Centro de Pesquisa da Universidade de Columbia, onde $50 \%$ da renda provinham dessas pesquisas, criticou severamente a posição dos pesquisadores na retomada do modelo das ciências naturais e exatas, que buscavam atender as demandas mercadológicas e publicitárias das empresas e que foi chamada de "crítica dos clientes" (MARTINS, 2004).

$\mathrm{Na}$ atualidade, apesar da pouca atenção dada nos trabalhos atuais sobre as questões éticas que envolvem a pesquisa qualitativa, existe uma complexa discussão - em sua maioria por antropólogos - que procuram analisar severamente a postura do pesquisador. Para Martins

A presença de pesquisadores, muitas vezes disfarçada, pode envolver os observados, pode manipulá-los de acordo com seus interesses e objetivos, introduzindo tensões, provocando rupturas. Segundo Zaluar (1986), o cientista social não deve esquecer que a relação que se estabelece entre o observador e o observado é uma relação social e política. Para o pesquisador, com muita frequência, o 
mais importante é a pesquisa a ser feita, e os outros são vistos como informantes, ou seja, devem estar a serviço dele para lhe fornecerem os dados que lhe são fundamentais - "fundamentais, na verdade, para a sua carreira e não para a vida daquele grupo ou para os indivíduos que dele fazem parte. (MARTINS, 2004: 296).

Partindo destes pressupostos, Murphy e Dingwal propuseram uma "teoria ética" cujo intuito maior é preservar a pesquisa qualitativa através das posturas de seus pesquisados e pesquisadores. A primeira questão é a que os autores chamaram da não-maleficência, que implica em um cuidado dos pesquisadores para evitar qualquer dano moral ou físico a seus pesquisados; a segunda questão, beneficência, diz que pesquisas relacionadas a temas humanos devem produzir algum tipo de benefício aos pesquisados em vez de promover apenas o interesse do pesquisador. A autonomia ou autodeterminação que segundo os autores estaria relacionada a valores e decisões dos participantes que devem ser respeitados em qualquer circunstância. Finalmente a justiça que prediz que todas as pessoas devem ser tratadas igualmente (FLICK, 1995).

Em suma, a pesquisa qualitativa pode ser compreendida como o estudo centralizado no específico, buscando mais a compreensão do que a explicação dos fenômenos estudados (MARTINS \& BÓGUS, 2004, p.48). Esse fato, no entanto, não delimita o trabalho qualitativo e nem impossibilita utilizar os dados para a compreensão de outros fenômenos.

Outro fator que finaliza a discussão, em um contexto mais amplo, da pesquisa qualitativa é a triangulação. Ao se retratar um fenômeno estudado, os dados devem ser coletados de diferentes situações e fontes, para a compreensão de maneira mais completa do estudo. Assim, uma estratégia proposta é a triangulação dos dados obtidos em diferentes técnicas de coletas, pesquisadores e observados. Martins e Bógus (2004) lembram que

Turato (2003) discute o emprego do termo triangulação já que ele se ampliou tanto que pode se referir a: múltiplas amostras; múltiplos pesquisadores; diferentes abordagens teóricas; diferentes métodos e técnicas. Aconselha que o pesquisador informe claramente a que 
está se referindo ao utilizar o termo triangulação, isto é, se está utilizando, para o mesmo projeto, vários sujeitos ou mais de uma amostra para estudar o mesmo tema, mais do que um pesquisador para colher os dados, mais de um referencial teórico para interpretar os resultados ou mais de uma técnica de investigação (MARTINS \& BÓGUS, 2004: 55).

Silverman (2006) ressalva que a suposição de que os diversos métodos correspondem e extraem as mesmas conclusões ou ao menos similares, dando status de completude pode ser uma falácia. $O$ autor enfatiza a partir dos trabalhos de Fielding e Fielding (1986) que métodos frequentemente extraídos de diferentes teorias não podem dar uma verdade "objetiva". Ele continua reforçando a ideia de que mesmo quando usamos um único modelo analítico, pode ser enganoso agregar dados para chegar a uma 'verdade' geral (SILVERMAN, 2006: 262). Ou seja, para ele

a triangulação não é uma maneira de se obter uma leitura 'verdadeira', mas é mais bem entendida como uma estratégia que adiciona rigor, amplitude, complexidade, riqueza e profundidade a qualquer investigação (Denzil e Lincoln, 2000, p.5). O ‘erro' só surge quando os dados são usados para julgar entre relatos, pois isso reduz o papel do pesquisador ao que Garfinkel (1967) denomina um 'ironista', usando um relato para substituir outro, enquanto permanece cego ao sentido de cada um no contexto em que ele surge. Por fim, o principal problema da triangulação como um teste de validade é que, se contrapondo a diferentes contextos, ignora o caráter vinculado ao contexto e hábil da interação social, assumindo que os membros são 'idiotas culturais' que precisam de um cientista social para afastar suas ilusões (SILVERMAN, 2006: 263).

Essa perspectiva revela a necessidade de abrangência dos métodos sem, no entanto, apresentar os resultados obtidos como respostas a questões levantadas, mas como oportunidade de reflexão e aprofundamento daquilo que se propôs a olhar, procurando aprimorar o mundo do pesquisado. Nesse contexto, na próxima seção, discutiremos o papel da filosofia de pesquisa na coleta e análise de dados. 


\subsection{A metodologia qualitativa: uma breve discussão de suas perspectivas}

De modo geral, a metodologia qualitativa pode ser dividida através de sua abordagem teórica, ou seja, sua forma de compreender o objeto de estudo e seu foco metodológico. Flick (1995) distingue essa abordagem em três perspectivas principais: a) a tradição interacionista simbólica e fenomenologia; b) a etnometodologia e construcionismo e c) posturas estruturalistas e psicanalíticas.

Na primeira perspectiva há um predomínio do processo que busca a recusa da construção a priori de conceitos e hipóteses de pesquisa sobre o fenômeno social pesquisado, para então elaborar uma teoria a partir da descrição de um fenômeno. Partindo desta ideia a definição do objeto de pesquisa é feita observando o fenômeno social do qual se busca aprofundar a análise teórica e na compreensão, também, em um sentido amplo, que emerge da totalidade do sistema social (GUTBERLET, 2010).

A elaboração das categorias conceituais, entendendo o conceito como unidade básica da análise, indica a representação que incide desse entendimento; a categoria conceitual permanece sensível à realidade pesquisada. Neste contexto, ela respeita e entende que: a) os fatos são cruciais; b) os fatos são indicadores dos conceitos e das categorias conceituais; c) os fatos são os últimos instrumentos para a sua verificação e d) as categorias conceituais são modificadas até que nenhum dado novo venha a contradizê-los: o princípio da saturação (GUTBERLET, 2010). São usualmente utilizadas as entrevistas semi-estruturadas ou narrativas e dos procedimentos de codificação e análise de conteúdo (FLICK, 2006).

A segunda perspectiva, a etnometodologia, tem como interesse principal a rotina e a produção da realidade social; visando a descrição de fenômenos sociais e sua relação social estabelecida. O estudo das práticas estabelecidas no cotidiano das instituições, tanto de suas relações internas como externas, é o foco de seus pesquisadores. A análise das conversações tem o intuito de estudar a fala dos sujeitos envolvidos no processo e compreender as interações sociais que se estabelecem. Os trabalhos de Harold Garfinkel que se iniciaram em meados de 1967, são considerados pioneiros, no campo de pesquisa da análise do discurso, 
que emergiram dos estudos nessa perspectiva. A coleta dos dados em sua maioria é feita através de grupos focais, de pesquisa etnográfica, da observação participante e de gravações audiovisuais analisando-as através do discurso ou conversação (FLICK, 1995).

A terceira e última perspectiva se preocupa com a compreensão das posturas estruturalistas e mecanismos psicológicos inconscientes e configurações sociais latentes (FLICK, 1995: 28). Sua abordagem pode ser definida como uma reconstrução das estruturas psicológicas profundas que geram uma ação e significado a essa ação. Para os estruturalistas, a estrutura é estável, mas não permanente. Quando o sistema sofre mudanças quantitativas que alteram a sua essência, transformam os elementos do objeto e surgem outras estruturas, outros corpos, com outras qualidades (TRIVIÑOS, 1987: 80).

Além da psicologia, esse tipo de perspectiva também utiliza a "hermenêutica objetiva" para a análise de narrativas em três variantes de exposição como cita Reichertaz (apud FLICK, 1995): a análise detalhada do texto estudado para a pesquisa em oito níveis distintos, dando ênfase no conhecimento e contexto externo para compreensão do todo; a análise sequencial que é a mais complexa das variantes, submete cada contribuição individual para uma interação gradual da declaração do pesquisado e a interpretação completa dos dados sociais objetivos que deve ser feita com todos os participantes antes da realização dos trabalhos. As ferramentas mais utilizadas neste tipo de perspectiva são as audiovisuais como fotografia e filmes (FLICK, 1995).

Na tabela 2.1, há uma proposta de Uwe Flick (1995) de organização das principais posturas teóricas, métodos e campos que se relacionam com cada perspectiva na pesquisa qualitativa. 


\begin{tabular}{|c|c|c|c|}
\hline & $\begin{array}{l}\text { Abordagens aos } \\
\text { pontos de vista } \\
\text { subjetivos }\end{array}$ & $\begin{array}{l}\text { Descrição da } \\
\text { produção de } \\
\text { situações sociais }\end{array}$ & $\begin{array}{l}\text { Análise hermenêutica } \\
\text { das estruturas } \\
\text { subjacente }\end{array}$ \\
\hline Posturas teóricas & $\begin{array}{l}\text { Interacionismo } \\
\text { simbólico } \\
\text { Fenomenologia }\end{array}$ & $\begin{array}{l}\text { Etnometodologia } \\
\text { Construtivismo }\end{array}$ & $\begin{array}{l}\text { Psicanálise } \\
\text { Estruturalismo genético }\end{array}$ \\
\hline $\begin{array}{l}\text { Métodos de coleta de } \\
\text { dados }\end{array}$ & $\begin{array}{l}\text { Entrevistas semi- } \\
\text { estruturadas } \\
\text { Entrevistas narrativas }\end{array}$ & $\begin{array}{l}\text { Grupos Focais } \\
\text { Etnografia } \\
\text { Observação } \\
\text { participante } \\
\text { Coleta de documentos }\end{array}$ & $\begin{array}{l}\text { Gravação de interações } \\
\text { Fotografia } \\
\text { Filmes }\end{array}$ \\
\hline $\begin{array}{l}\text { Métodos de } \\
\text { interpretação }\end{array}$ & $\begin{array}{l}\text { Codificação teórica } \\
\text { Análise de conteúdo } \\
\text { Análise narrativa } \\
\text { Métodos hermenêuticos }\end{array}$ & $\begin{array}{l}\text { Análise de conversação } \\
\text { Análise do discurso } \\
\text { Análise de gênero } \\
\text { Análise de documentos }\end{array}$ & $\begin{array}{l}\text { Hermenêutica objetiva } \\
\text { Hermenêutica profunda }\end{array}$ \\
\hline Campos de aplicação & $\begin{array}{l}\text { Pesquisa bibliográfica } \\
\text { Análise de } \\
\text { conhecimento cotidiano }\end{array}$ & $\begin{array}{l}\text { Análise das esferas de } \\
\text { vida e de organização } \\
\text { Avaliação } \\
\text { Estudos Culturais }\end{array}$ & $\begin{array}{l}\text { Pesquisa de família } \\
\text { Pesquisa biográfica } \\
\text { Pesquisa de geração } \\
\text { Pesquisa de gênero }\end{array}$ \\
\hline
\end{tabular}

In: Flick, U. Introdução à pesquisa qualitativa (2009, p.30)

Em suma, a diversidade que se submete a pesquisa qualitativa do ponto de vista de suas perspectivas ainda é plausível de outras concepções. No entanto, neste capítulo nos focamos naquelas que atualmente ganharam maior abrangência no campo das ciências sociais e que, de certa forma, dialogam com o campo da pesquisa em educação em ciências. É importante salientar que os métodos e análises de dados que acima foram mencionados são representativos na maioria das pesquisas relacionadas e, portanto, ilustrativos e não obrigatórios. Essa ressalva é importante, pois o trabalho aqui apresentado se vale de diversas estratégias para obtenção dos dados e não se submete a um tipo de método de coleta; assim não focaliza o olhar a um tipo de perspectiva. Ainda, nesse contexto, a triangulação das estratégias terá como intuito mostrar a complexidade do objeto estudado e a riqueza de elementos a serem explorados e que esse trabalho dá conta em uma pequena parcela.

Nas seções que se seguem será apresentado, na perspectiva desse trabalho, o método a ser utilizado para coleta de dados e sua metodologia de análise.

\subsection{Norteando os caminhos: os métodos e estratégias na coleta de dados}

A rivalidade entre os paradigmas e a triangulação de perspectivas são temas recorrentes nas pesquisas em ciências sociais e nas pesquisa em educação. $O$ foco 
da discussão se relaciona à validade do trabalho quando este é direcionado para apenas uma visão do objeto estudado. A conclusão que se está chegando sobre o tema é que a triangulação dessas perspectivas seja a melhor saída para a compreensão de um contexto maior sobre uma pesquisa. Esse processo é defendido como dialético e, portanto, sua procura não pode ser limitada a uma perspectiva.

A defesa pela triangulação é de uma ampliação do olhar para o fenômeno estudado, mas, no entanto, pode ser defendida que a escolha por uma única perspectiva pode ser aceita, rejeitando criticamente as outras. Para Uwe Flick (1995) a alternativa para resolver tal polêmica é entender que a escolha por essas visões teóricas distintas podem ser compreendidas como diferentes caminhos de acesso para o mesmo fenômeno.

Para os estudiosos, aspectos comuns das diferentes posturas podem de certa forma, ajudar a resolver tal problema. O Verstehen como princípio epistemológico é um desses aspectos, ele indica a compreensão do fenômeno a partir de seu estudo interior; a reconstrução de casos como ponto de partida, ou seja, o fato de um caso ser analisado antes da elaboração de enunciados comparativos ou gerais; a construção da realidade como base, onde os casos ou tipologias reconstruídos possuem vários níveis de construção de realidade sendo, portanto, uma realidade construída por diferentes sujeitos (FLICK, 1995: 76) e o texto como material empírico, onde são apresentados e processados para que as análises possuam a clareza da coleta.

Respeitando tais aspectos, esse trabalho reconhece-se nas perspectivas das construções das realidades sociais ou etnometodologia e na composição cultural da realidade social e subjetiva ou modelos estruturalistas. No entanto, compreendendo a natureza dos dados a serem apresentados e o contexto do trabalho, iremos focar os interesses na análise dos métodos empregados por membros da realidade na vida cotidiana (FLICK, 1995: 71). Em suma, Garfinkel (1967) compreende que:

Os estudos etnometodológicos analisam as atividades cotidianas como métodos dos seus membros que visam a tornar essas mesmas atividades visivelmente racionais e relatáveis a todo tipo de propósito 
prático, ou seja, "explicáveis" enquanto organizações de atividades cotidianas triviais. A reflexividade desse fenômeno é uma característica singular das ações e das circunstâncias práticas, do conhecimento oriundo do senso comum sobre as estruturas sociais e do raciocínio sociológico prático (GARFINKEL apud. FLICK, 1995: 71)

No geral, a etnometodologia se preocupa com a diversidade de atividades cotidianas utilizando a análise formal da conversação. Seu foco nos últimos vinte anos tem sido nos estudos sobre trabalho, onde esses processos são estudados em um sentido amplo e particularmente dentro do contexto do trabalho científico em laboratórios, ou, por exemplo, no modo como os matemáticos constroem suas provas (FLICK, 1995: 72). Apesar do contexto do trabalho aqui apresentado não se debruçar sobre a atividade científica em si, ou seja, na sociologia do conhecimento, possui um aspecto prático no que tange a procura por tornar a "descrição" da atividade científica mais palatável para a comunidade escolar.

Nas próximas seções buscaremos discutir as estratégias metodológicas utilizadas para coleta de dados, enfatizando seus aspectos teóricos. Para tanto, apresentaremos algumas concepções acerca da utilização de dados visuais, grupo focal, questionários, entrevista semi-estruturada e a etnografia.

\subsubsection{A produção dos dados visuais para análise de vídeo}

A produção dos dados visuais para a pesquisa é um importante meio de compreender como os acontecimentos estudados apresentam suas ações temporais e reais ao longo do processo (LOIZOS, 2002). Elas são importantes, nesse trabalho, pois evocaram como as interações entre cientistas e público se dá no contexto do laboratório científico. Isso implica em olhar para o objeto estudado, nos ajudando a compreender momentos e situações que não são passíveis de serem observados in loco. Ou seja:

O vídeo tem uma função óbvia de registro de dados sempre que algum conjunto de ações humanas é complexo e difícil de ser descrito compreensivamente por um único observador, enquanto ele se desenrola (LOIZOS, 2002: 149) 
Assim, a coleta de dados com dois pesquisadores, utilizando uma câmera de vídeo cada um, para que se pudesse ter acesso a diversos ângulos e captação de som e imagem capaz de permitir a transcrição das falas e inserção de percepções, de forma clara e evitando inferências equivocadas sobre o material analisado.

\subsubsection{A coleta de dados no grupo focal}

Os grupos focais vêm se tornando importantes meios de coleta de dados na pesquisa no país, principalmente em trabalhos direcionados para a área de saúde. Seus dados se mostram capazes de trazer dimensões reveladoras de ideias e comportamentos, através da fala e posturas dos pesquisados, em debate com outros sujeitos (BELLIZIA et. al.; 2010). Para esse trabalho, adotamos a definição de Morgan (1997), que considera essa técnica de pesquisa como meio das interações grupais ao se discutir um tópico especial sugerido pelo pesquisador. Ocupa posição intermediária entre a observação participante e as entrevistas em profundidade (MORGAN apud GONDIM, 2002)

Essa interação direta entre pesquisado e pesquisador promove um direcionamento ao tema estudado, enfatizando assuntos de interesse da pesquisa, sem, no entanto, descaracterizar o contexto em que determinada fala aparece nas discussões grupais. Para Rosaline Barbour uma grande vantagem dessa técnica é a sua capacidade de capturar respostas e eventos enquanto se desenrolam (BARBOUR, 2008: 46)

Para a autora o sucesso nesse tipo de técnica está em submeter os dados a uma análise que vá além da descrição dos dados, no caso da ciências sociais.

A chave para se produzir achados de pesquisa que transcendam o puramente descritivo e comecem a ser analíticos reside no estudo dos padrões em nossos dados. Isso é possível quando se presta bastante atenção ao projeto de pesquisa e se seleciona participantes com o intuito de maximizar o potencial de comparação. Análises se tornam mais do que simplesmente extração de temas a partir dos dados, passando, então, a envolver um processo de interrogar os dados, contextualizar comentários, desenvolver tentativas de 
explicação e submetê-las a mais interrogação e refinamentos (BARBOUR, 2008: 48)

Nesse sentido, buscou-se trazer para o grupo focal participantes que pudessem, de certo modo, ser representativos no universo estudado e, ao mesmo tempo, procurou-se respeitar as posições individuais dos sujeitos e suas histórias de vida, para que a análise dos dados não se comprometesse com posições catárticas dos participantes (BARBOUR, 2008: 124).

Sendo assim, conduziram o grupo focal dois pesquisadores: um moderador, que foi incumbido de introduzir o tema e organizar as falas, para que o diálogo não fosse direcionado para outros assuntos, e o um observador, que gravou o vídeo visando capturar momentos e reações dos participantes que pudessem se mostrar reveladores.

\subsubsection{Questionário para percepção dos estudantes acerca das visitas}

A ferramenta questionário é conhecida como um instrumento com elevado número de questões que tem como objetivo conhecer opiniões, expectativas, situações vivenciadas, etc. de um grupo de pessoas. Sua principal vantagem é que pode garantir o anonimato do pesquisado e permitir certo distanciamento do pesquisador e sua possível influência. Em contrapartida, traz consigo problemas relacionados ao não entendimento das questões pelos pesquisados, o retorno de questões sem respostas ou leva a resultados críticos, pois os itens podem ser compreendidos de formas diferentes entre os participantes (PARFITT, 2005; GIL, 2006).

O questionário aplicado aos estudantes após sua visita ao laboratório se constituiu de perguntas abertas, ou seja, os pesquisados puderam inserir respostas em espaços abaixo das questões sem forçar os entrevistados a um enquadramento em situações já pré-estabelecidas pelo pesquisador. O conteúdo das questões utilizadas se enquadra na categoria sobre atitudes e crenças. Segundo Gil (2006)

Questões dessa natureza são as mais difíceis de ser respondidas. Primeiramente, porque nem sempre as pessoas têm uma atitude ou mesmo uma opinião sobre o assunto, já que pode ocorrer que nunca 
tenham pensando nele. Depois, porque as pessoas podem não ter uma atitude global sobre determinado assunto (...) (GIL, 2006: 132)

Tais problemas persistiram nos questionários coletados dos pesquisados, trazendo nas respostas questões ambíguas ou difíceis de serem analisadas. No entanto, puderam ser percebidas algumas dimensões construtivas para 0 desenvolvimento do estudo.

\subsubsection{As entrevistas semi-estruturadas com os especialistas}

Foram utilizadas para a coleta de dados com os cientistas as entrevistas semi-estruturadas, que possuem como principal característica a possibilidade de promover diálogos espontâneos sobre determinados assuntos através da utilização de questões abertas. Nesse tipo de estratégia, essas questões se tornam interessantes, pois evocam conhecimentos que os entrevistados possuem sem, no entanto, forçar assuntos considerados inconvenientes pelos pesquisados (FLICK, 1995).

Essa entrevista possui como componentes básicos algumas questões que são apresentadas ao entrevistado e deixa, a cargo do mesmo, a melhor maneira de apresentar suas opiniões, a ordem das respostas é aleatória e o entrevistador busca intervir o mínimo possível nesse processo.

Como forma específica de aplicar as entrevistas semi-estruturadas está a entrevista com os especialistas, onde segundo Flick (1995)

(...) há aqui um menor interesse nos entrevistados enquanto pessoa (como um todo) do que em sua capacidade de ser um especialista para um determinado campo de atividade. Elas são integradas ao estudo não como um caso único, mas representando um grupo. (FLICK, 1995: 158)

Nesse contexto, foi analisada a fala desses pesquisados buscando trazer dimensões sobre as visitas e o fazer científico, segundo a visão desses profissionais. 


\subsubsection{O método etnográfico na entrada no campo de pesquisa}

O trabalho etnográfico implica na entrada do pesquisador na vida cotidiana das pessoas com a finalidade de observar, escutar e participar desse ambiente para coletar dados a fim de esclarecer dúvidas e compreender as dinâmicas dos pesquisados (FLICK, 1995: 214). A imersão nesse campo de pesquisa foi feita através do que a etnometodologia chama de "membro de boa-fé". Este tipo de imersão no campo relaciona-se ao fato do pesquisador imergir no processo de trabalho pesquisado e na condição de membro da comunidade.

Isso se deu de maneira não proposital, mas como aluna de iniciação científica. O processo de introdução e reconhecimento do trabalho realizado no acelerador foi feito através da participação em um projeto no laboratório de eletrotécnica, produzindo juntamente com os técnicos do acelerador a montagem do aparato experimental que reproduzia o tanque do acelerador em uma escala menor. Durante o processo a imersão de campo, foi produzido junto com outros integrantes deste projeto um trabalho mais tarde apresentado em um congresso da área de física nuclear. Concomitantemente à produção do protótipo ocorreram diversas interações (conversas, entrevistas abertas, documentos) que serviram de apoio para a compreensão dos fundamentos científicos relacionados ao acelerador e da postura científica dos pesquisadores/docentes.

O acesso à instituição não passou por um "exame oficial", ou seja, a solicitação em termos formais com justificativa de pesquisa, método, tempo; pois a pesquisa foi "pré-estruturada", ou seja, o pesquisador foi encaminhado ou orientado por um membro da instituição. Este tipo de entrada em campo é entendido como "trabalho de consentimento", que consiste no pesquisador se encaixar nas rotinas administrativas e é tratado com procedimentos institucionalmente familiares (FLICK, 1995: 111).

Assim, se procurou fazer inferências associadas às percepções provindas da observação e vivenciadas no campo, sem, no entanto, trazer uma verdade absoluta sobre o que é discutido, mas uma reflexão daquilo que foi observado. 


\subsection{Norteando os caminhos: as dimensões de análise dos dados}

A análise dos dados, nesse trabalho, será apresentada em duas dimensões, onde se procura atrelar as reflexões acerca dos temas explorados nos capítulos anteriores com o material coletado. Para tanto, se propõe, em um primeiro momento, analisar os dados de acordo com seu formato de origem: site, visitas, etc., buscando apresentar suas características em cada caso e trazendo algumas reflexões sobre as perspectivas de atuação que possibilitaram. Em um segundo momento, pretendemos realizar essa mesma análise de forma mais integrada, analisando esse material em relação à articulação entre essas diversas estratégias de análise.

Para que isso ocorra, não serão apresentadas categorias que sejam representantes dos temas educacionais em $\mathrm{si}$, mas das diversas relações que esses temas possuem em relação ao espaço de produção da ciência - ou seja, o elemento privilegiado nas discussões desse trabalho. Procura-se com essa estratégia de análise, evidenciar o papel do laboratório, em sua singularidade, e ao mesmo tempo, trazer reflexões pedagógicas que possibilitem olhar para os dados de uma maneira mais aprofundada.

Essas duas dimensões de análise se pautarão em três temas pedagógicos já abordados até o momento: a perspectiva social do laboratório científico, a alfabetização científica e as ideias do movimento CTS. Em suma, serão apresentadas as diversas possibilidades de diálogo entre essas visões, a fim de ajudar na leitura dos dados. Tais posturas procuram fazer a ligação entre seus pressupostos e o espaço de produção da ciência e sugerem olhar as dimensões em que elas atuam e não nos elementos que a representam.

Isso reflete em compreender que nas escolhas das grandes perspectivas de análises, onde suas categorias representativas aparecem para facilitar a organização dos dados, não fazem parte de um olhar dos pressupostos pedagógicos em si, mas de sua articulação com a produção da ciência apresentada nos laboratórios científicos. Ou seja, não se procura olhar para os dados a partir dos pressupostos da Alfabetização Científica ou CTS, mas das relações provindas dessas ideias e do laboratório que se quer apresentar. 
Assim, quando se aborda o contexto social do laboratório, não se procura apenas compreender as relações entre os indivíduos, mas também abranger essas discussões para a compreensão da relação ciência e tecnologia nesses espaços, que fazem parte das discussões sobre CTS. Nesse contexto, quando se traz a discussão sobre o conhecimento científico e a preocupação na alfabetização científica do público aparece a demanda em compreender as finalidades desses saberes na pesquisa do acelerador, articulando-os com a inserção desse conhecimento na sociedade.

Em suma, as perspectivas de análise refletem um esforço reflexivo de compreender as diversas demandas que recaem sobre os laboratórios científicos em função de sua intencionalidade educacional. Recaindo sobre a análise a tarefa de compreender a existência da consonância entre os objetivos que se propõem aqueles que pensam as visitas e a percepção do público acerca dessas estratégias.

Desse modo, em um primeiro momento, a perspectiva de análise se pautará em uma abordagem mais direcional, enfatizando aspectos sobre o material analisado de forma a compreender os elementos abordados em cada atividade. Essa tentativa, de olhar individualmente para esses dados, procura trazer uma visão limitada, mas focada, sobre os elementos que os representam, dando ênfase nas limitações de tais abordagens em prol de um olhar crítico sobre o material. Tal postura é trazida no capítulo 6 em paralelo a apresentação dos resultados da coleta de dados.

O segundo momento se refere a um contexto mais amplo de análise. Ele é apresentado no capítulo 7 , onde é analisado o conjunto das ações sob os pressupostos da educação discutidos nesse trabalho. Eles refletem um esforço de compreender as articulações entre as ideias pedagógicas e os espaços de produção da ciência, enfatizando como essas relações - estabelecidas a priori nas categorias de análise - se articulam para construir um entendimento sobre o laboratório científico e os diversos saberes atrelados a ele.

Essas duas formas de olhar os dados se mostraram importantes para 0 aprofundamento das reflexões e uma maior abrangência acerca das inferências provindas desses dados. Tais perspectivas, a individualizada e a abrangente, 
consideradas complementares, permitiram um entendimento dos dados tanto na perspectiva crítica quanto na perspectiva teórica desse material. 


\title{
Capítulo 6
}

\section{O que é apresentado e o que é compreendido}

\author{
Todo brasileiro poderá dizer: é assim que eu quero o Srasil, \\ todo brasileiro e nãa apenas o bacharel ou o doutor \\ o preto, o pardo, o roxo e nãa penas o branco e o semibranco
}

Gilbento ofregre

Esse capítulo se constitui em uma mescla de aspectos dos muitos trabalhos desenvolvidos, com o intuito de descrever, de forma sistematizada, o conjunto de elementos que se constituirá em nossa amostra de dados ou material de análise. Em um momento seguinte (capítulo 7), será apresentada a análise propriamente dita desses dados, com o objetivo de construir estratégias, compreender as formas de interação possíveis com o público e a tentativa de observar os sentidos atribuídos por aqueles que participaram e interagiram com esse material. Por isso, o processo de apresentação dos dados se deu em diversas instâncias, onde foi necessário um distanciamento do pesquisador, mesmo quando o material analisado também apresentou a participação do mesmo.

Esse tipo de reflexão não é comum em pesquisa, uma vez que o material, ainda que muitas vezes desenvolvido com a participação da própria autora, não foi construído com a intenção da análise, e, portanto, não se caracterizando como pesquisa participante nem como pesquisa em ação. Trata-se, portanto, de uma reflexão a posteriori, realizada após um distanciamento no tempo.

Essa abordagem reflete um amadurecimento do trabalho, inserindo novas dimensões do pensamento teórico para análise do material e possibilitando a inserção crítica de novos elementos, visando o objetivo maior de promover uma reestruturação daquilo que foi construído.

Propomos como organização estrutural, sistematizar os dados em três conjuntos. No primeiro, descrever em um primeiro momento, as estratégias desenvolvidas para promover à divulgação do laboratório, em seguida, algumas falas dos visitantes para indicar problemas e potencialidades desse material em 
interação com o público e também, a fala dos cientistas sobre as diversas formas de apresentar a ciência que eles produzem.

A última parte se refere ao diário de bordo da entrada de campo (laboratório) com o intuito de enfatizar alguns elementos sobre o fazer científico que não aparecem no contexto dos dados, mas foram considerados relevantes para serem incorporados no debate proposto nesse projeto. Para isso é feito um breve relato sobre as impressões do pesquisador sobre os trabalhos dos técnicos e sua possível participação na construção do conhecimento científico.

\subsection{O universo da ciência do laboratório que é apresentado para o público.}

A primeira parte desse capítulo refere-se às estratégias que foram desenvolvidas ao longo dos últimos seis anos com o intuito de apresentar para o público a ciência do laboratório Pelletron. Para que isso ocorresse, muitas das atividades apresentadas foram construídas através de parcerias com: alunos, técnicos e pesquisadores do departamento ou de outras instituições. Assim, esse material constitui um trabalho coletivo e, portanto, traz diversos olhares sobre o mesmo objeto, tornando-o ao mesmo tempo, rico e complexo, para ser analisado.

Essa dificuldade se refere em muitos aspectos às diversas maneiras de se olhar para as finalidades desses materiais e suas implicações para a identidade do trabalho como um todo. Nesse sentido, nas próximas seções, buscaremos fazer um panorama de algumas dessas construções, que tiveram o intuito de aproximar o público do mundo dos cientistas. Em paralelo, apresentamos uma análise dos materiais de forma a apontar suas características de atuação individuais. Essa postura possibilitou compreender as diferentes perspectivas de se apresentar o laboratório Pelletron e uma visão crítica acerca das interações propiciadas por esse material.

\subsubsection{Site do Laboratório Aberto de Física Nuclear}

O site do laboratório foi desenvolvido por um docente do Departamento de Física Nuclear em parceria com estudantes da Empresa Júnior da Escola de Comunicações e Artes (ECA) da USP. Após um período de desenvolvimento do 
projeto por esses alunos e o professor, esse trabalho foi apresentado na disciplina "Metodologia para Produção Hipermídia" da ECA, para que o docente ministrante e outros alunos pudessem discutir questões relacionadas ao tipo de site apresentado, a arte e possíveis problemas técnicos relacionados à construção da página na internet.

Da criação do site, desde a primeira reunião até a entrega final, o intervalo de tempo foi de aproximadamente 10 meses (março a dezembro de 2008). Nesse período os alunos prepararam a plataforma necessária para que o docente do departamento pudesse inserir textos, materiais e links; além do layout, onde foram contatados pesquisadores do departamento para que pudessem sugerir modificações na página que estava sendo construída.

O modelo apresentado foi dividido em cinco partes: uma relacionada à física nuclear, outra ao acelerador de partículas, o material de apoio, as visitas e links. A página principal traz o logo criado pelo grupo da ECA com predominância das cores amarela e azul, que fazem alusão ao tanque do acelerador onde predominam essas cores. A primeira foto apresentada é o do próprio terminal do acelerador e há o indicativo sobre os agendamentos da visita para conhecer o laboratório. Nessa página inicial, o visitante pode começar a leitura pelos textos sobre as visitas e sobre o LAFN. Caso queira finalizar o texto, há um link indicado com a palavra mais onde a pessoa será levada ao texto completo. 


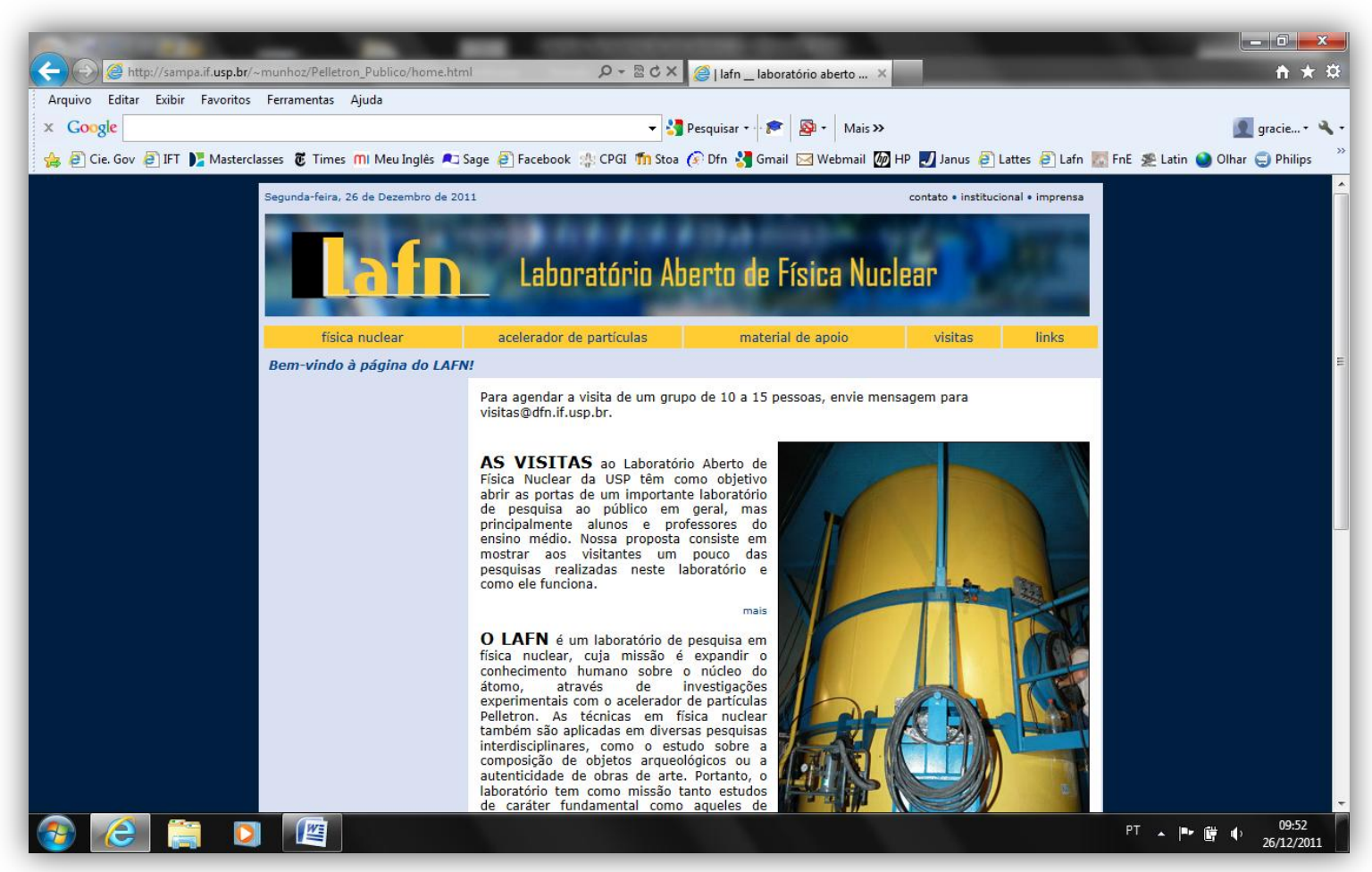

Figura 6.1: Site do Lafn (Laboratório Aberto de Física Nuclear)

Na primeira aba, referente à física nuclear, é apresentado uma tradução do material do Laboratório Nacional Lawrence Berkeley. A estrutura dessa parte do site é pensada como uma sequência de conteúdos sobre física nuclear onde são apresentados alguns temas e, em seguida, parágrafos com uma explicação sobre os mesmos. A ordem dessa lista é:

- Estrutura nuclear;

- Radioatividade;

- Decaimento alfa;

- Decaimento beta;

- Decaimento gama;

- Reações nucleares;

- Fusão;

- Fissão;

- Raios cósmicos. 


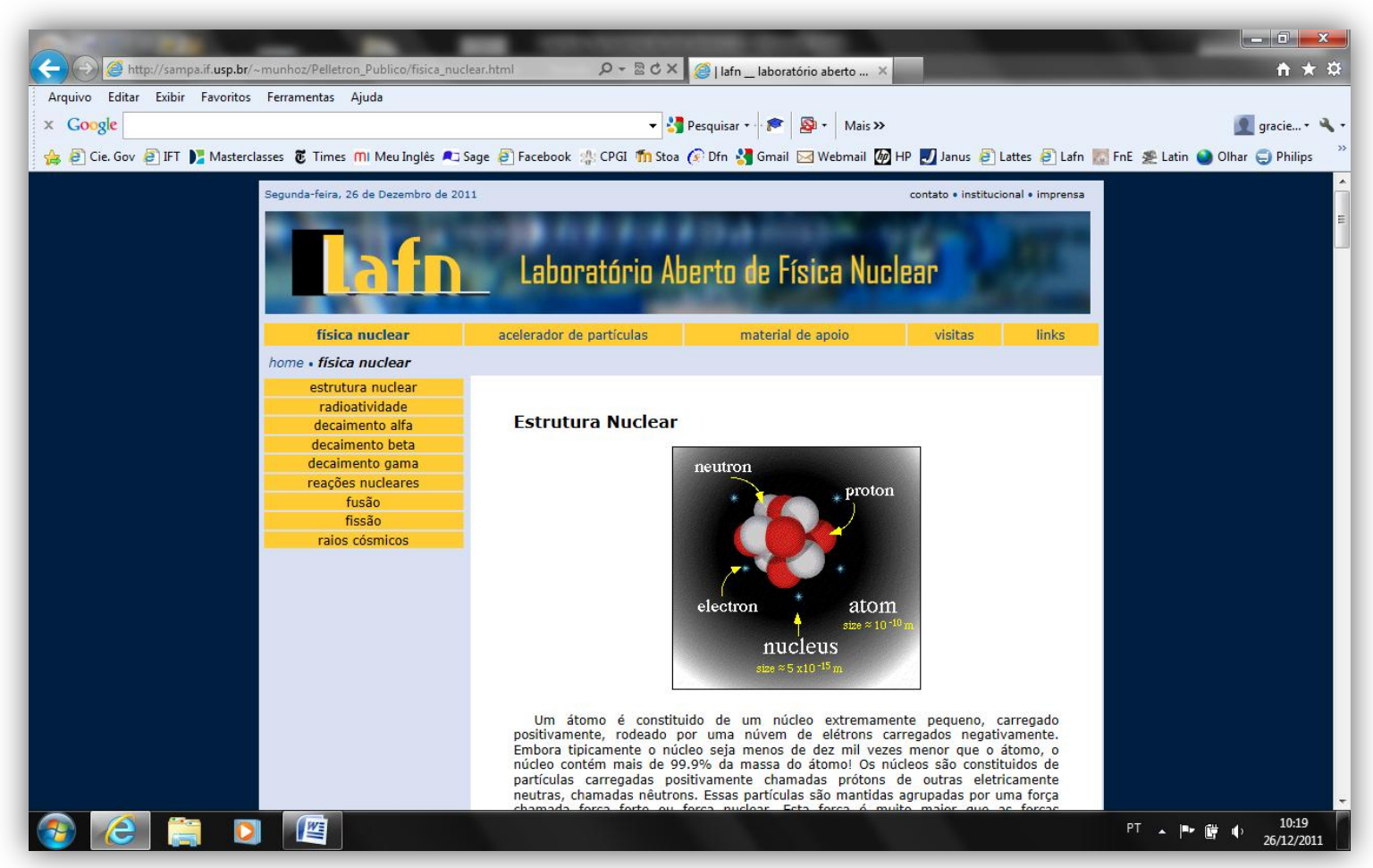

Figura 6.2: Site - Física Nuclear

Em alguns momentos aparecem figuras para ilustrar algum fenômeno ou modelos que estão sendo abordados no texto. Esse texto, no geral, aparece em forma de pequenos parágrafos que possuem a intenção de dar uma explicação ao tema do título. E geralmente, trazem termos e conceitos de física nuclear com a função de relacionar fenômenos naturais com explicações científicas pela linguagem matemática ou dos símbolos, pois são apresentados elementos da tabela periódica e equações de decaimento, no corpo do texto, sem, no entanto, indicativos de explicações sobre os mesmos.

A segunda aba sobre acelerador de partículas traz como subtítulo a frase: Pra que serve. Nela é discutida, de forma sucinta, a missão do laboratório, ou seja, de expandir o conhecimento sobre o átomo através da experimentação e são dados alguns exemplos sobre as aplicabilidades desses estudos como os trabalhos interdisciplinares.

"As técnicas em física nuclear também são aplicadas em diversas pesquisas interdisciplinares, como o estudo sobre a composição de objetos arqueológicos ou a autenticidade de obras de arte." 
"Portanto, o laboratório tem como missão tanto estudos de caráter fundamental como aqueles de caráter mais prático"

O texto é curto e de linguagem acessível. Há uma foto de parte da máquina, que não é especificamente do acelerador Pelletron, mas do projeto de sua extensão: o LINAC. O link sobre pesquisas que está nessa parte do site direciona o visitante para o site do departamento onde cada grupo de pesquisa possui sua página na internet. Na aba sobre material de apoio aparece o aviso "em construção" e, portanto, sem material para ser analisado até o momento.

Na parte sobre as visitas, é apresentado um texto sobre o objetivo da abertura do laboratório ao público, enfatizando o interesse por professores e alunos da escola básica. Discute sobre a intenção de desmistificar a visão do cientista e aproximar as pesquisas feitas no acelerador com a sociedade. Em seguida é indicado o roteiro da visita, trazendo um esquema que se inicia com a apresentação multimídia e os andares que serão conhecidos pelo público:

"As visitas ao Laboratório Aberto de Física Nuclear da USP têm como objetivo abrir as portas de um importante laboratório de pesquisa ao público em geral, mas principalmente alunos e professores do ensino médio. Nossa proposta consiste em mostrar aos visitantes um pouco das pesquisas realizadas neste laboratório e como ele funciona. Acreditamos que estas visitas possam aproximar o público das atividades de pesquisa e dos pesquisadores, desmistificando a atividade científica e mostrando como o conhecimento científico é produzido e, até mesmo, como o conteúdo de física do ensino médio está presente na investigação da fronteira do conhecimento."

Ao lado do texto há uma foto de um grupo de visitantes e ao fundo o prédio do departamento. 


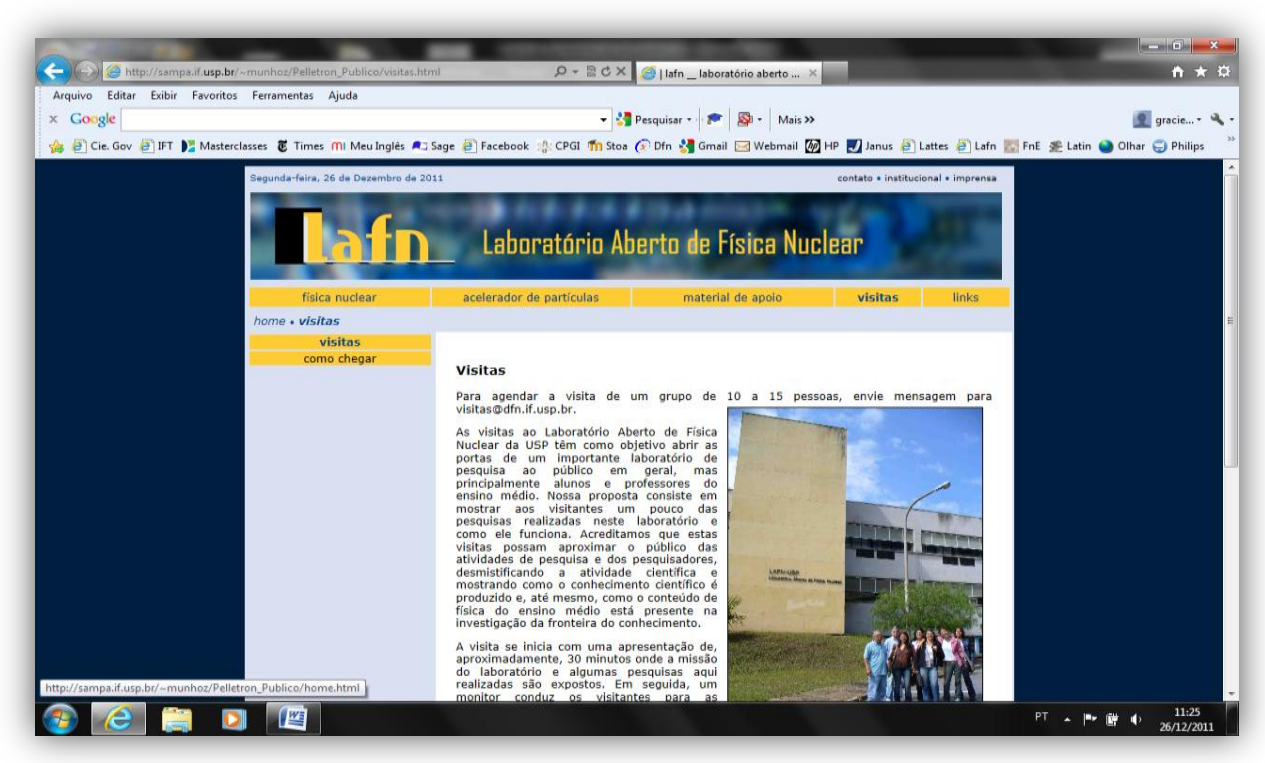

Figura 6.3: Site - Visitas

Finalmente, na parte links, são apresentados alguns sites com laboratórios que possuem aceleradores de partículas, como: Brookhaven National Laboratory, Fermi National Accelerator Laboratory e Organisation Européene pour La Recherche Nucléaire. Sites nacionais aparecem relacionados a materiais de física disponíveis para o ensino médio, direcionados aos professores e pesquisadores da área de ensino.

Em suma, o site analisado traz como elemento principal o conteúdo científico teórico de física nuclear. Isso é percebido quando se analisam os temas trazidos nas discussões sobre os fenômenos, aparecendo equações e símbolos, sem, no entanto, uma preocupação em contextualizar diretamente a importância dos mesmos para a experimentação no laboratório. Pressupõe-se que tal relação aparecerá de forma natural, ficando a cargo daquele que visita o site e o laboratório.

A própria estrutura de apresentação desses conteúdos dá pistas dessa intenção quando as listas sobre física nuclear aparecem em forma de blocos de montar, cuja função do leitor é produzir uma estrutura linear desse conhecimento sem, no entanto, indicações de como construir uma relação entre os conteúdos que antecedem e sucedem os temas.

Em relação aos objetivos da visita, ela aparece de forma descolada ao que é apresentado na página, pois o texto sobre a intenção de trazer o público ao 
laboratório evoca uma desmistificação do cientista e da ciência. No entanto, quando se observa o todo, é possível notar uma preferência pela apresentação do aparato experimental e dos conteúdos, além de um afastamento do cientista humanizado para uma sobreposição do conhecimento científico. Podem ser percebidas tais afirmações quando são analisadas as fotos no site, que dão ênfase nas máquinas ou nos visitantes, e em nenhum momento, aparecem pesquisadores e técnicos trabalhando no acelerador, por exemplo.

Assim, situações e discussões sobre como a ciência é produzida, quem as financia, questões éticas sobre as pesquisas; acabam por serem deixadas de lado em prol de uma abordagem mais focada no conhecimento científico. Apesar de importante, esses conteúdos só terão sentido quando abordados de forma contextualizada, imersos nas questões que o antecedem e o rodeiam e que, de certa forma, podem ser direcionadas no site para uma compreensão de forma mais abrangente do sentido de se fazer ciência, quando esses visitantes puderem conhecer esse laboratório.

Ou, caso contrário, proporcionar um aprofundamento sobre o tema após as visitas, quando, se espera que o público saia com mais perguntas que respostas, e procurem um direcionamento sobre suas dúvidas. De qualquer maneira, as duas formas de se olhar essa finalidade devem ser contempladas no site, pois, só assim, as visitas e seus complementos poderão promover uma reflexão sobre o sentido de se fazer física e que vá além dos conteúdos.

\subsubsection{Apresentação Multimídia}

A apresentação multimídia é uma forma utilizada nas visitas para introduzir o público ao laboratório, sendo ela a primeira atividade nas dependências do acelerador. Geralmente é proferido um seminário de cerca de 40 minutos, pelo docente que irá acompanhar o grupo, sendo o material uma forma de apoio para que o palestrante discuta alguns temas ligados à física nuclear e ao laboratório. Esse trabalho foi desenvolvido em parceria com dois pesquisadores e um aluno de artes gráficas, que juntos, produziram as animações utilizadas nos slides. 
São apresentados três momentos nessa atividade: a introdução institucional do laboratório e seu objetivo científico, as questões teóricas sobre física nuclear e algumas considerações acerca do funcionamento do acelerador. O primeiro momento busca situar o acelerador dentro do Departamento de Física Nuclear, que faz parte do Instituto de Física da USP. Em seguida, são apresentados dois objetivos do laboratório: ampliar o conhecimento sobre a natureza e aplicações tecnológicas.

O slide seguinte inicia o segundo momento, que é caracterizado pelas perguntas que iniciam os temas a serem explorados. A primeira delas é a questão: Que tipo de conhecimento queremos obter? Seguido de outra questão, ainda no mesmo slide: Do que são feitas todas as coisas? Esse é o mote para introduzir, no slide seguinte, uma animação onde é aumentado o zoom de um folha de árvore, cuja sucessão de imagens gera uma viagem que leva o público a passar pelos DNA, cromossomos, nuvem de elétrons até chegar ao núcleo atômico.

Então, é apresentada outra pergunta: Por que o núcleo não se desfaz com a repulsão dos prótons? A animação que acompanha essa parte mostra um núcleo com algumas flechas que representam uma força de repulsão. É oferecido, sucedendo tal animação, a explicação sobre a força forte.

Quantos prótons e nêutrons nós podemos "combinar" para formar um núcleo? É a questão que inicia o assunto para discutir a formação de núcleos exóticos. A animação que representa um dos fenômenos estudados traz a simulação do bombardeamento de nêutrons em um ${ }^{7} \mathrm{Li}$, formando os ${ }^{8} \mathrm{Li}$ e ${ }^{9} \mathrm{Li}$, mas não conseguindo formar o ${ }^{10} \mathrm{Li}$. Em seguida, ao serem bombardeados dois nêutrons ao mesmo tempo, forma-se o ${ }^{11} \mathrm{Li}$. 

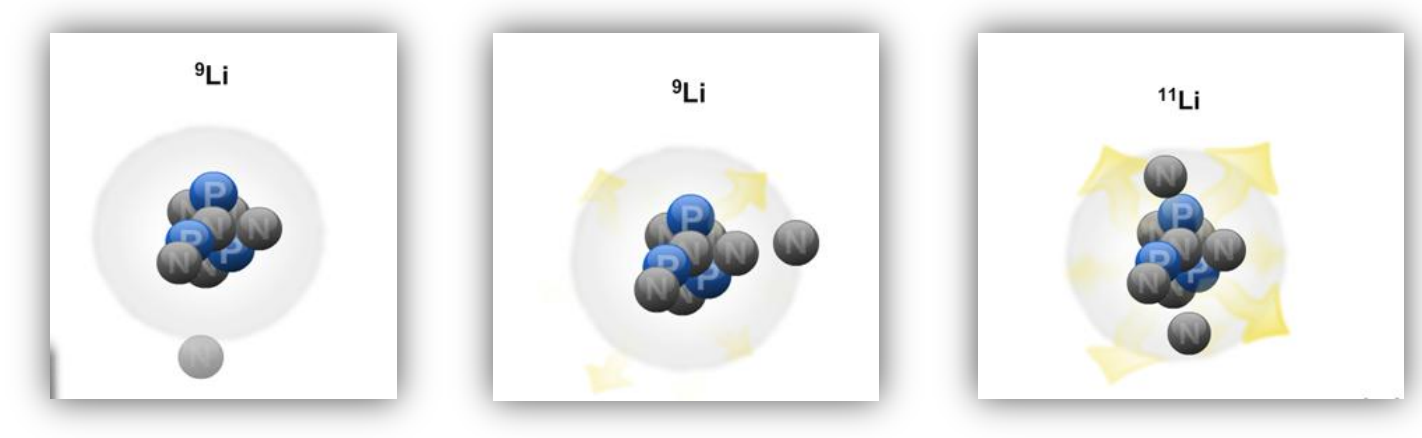

Figura 6.4: Formação de Núcleos Exóticos

A apresentação finaliza com o tamanho do núcleo atômico do ${ }^{11} \mathrm{Li}$ e do ${ }^{208} \mathrm{~Pb}$ para introduzir a questão sobre como núcleos com número atômico tão distintos possuem o mesmo tamanho. Esse é o impasse para introduzir a próxima questão: Qual o formato do núcleo? Onde aparecem diversos tipos de núcleos com diferentes formatos.

Outra pergunta é feita: O que acontece se atirarmos um núcleo contra outro? Assim é apresentada uma animação que mostra o fenômeno de tunelamento e sua referência, no gráfico simulado no mesmo slide.
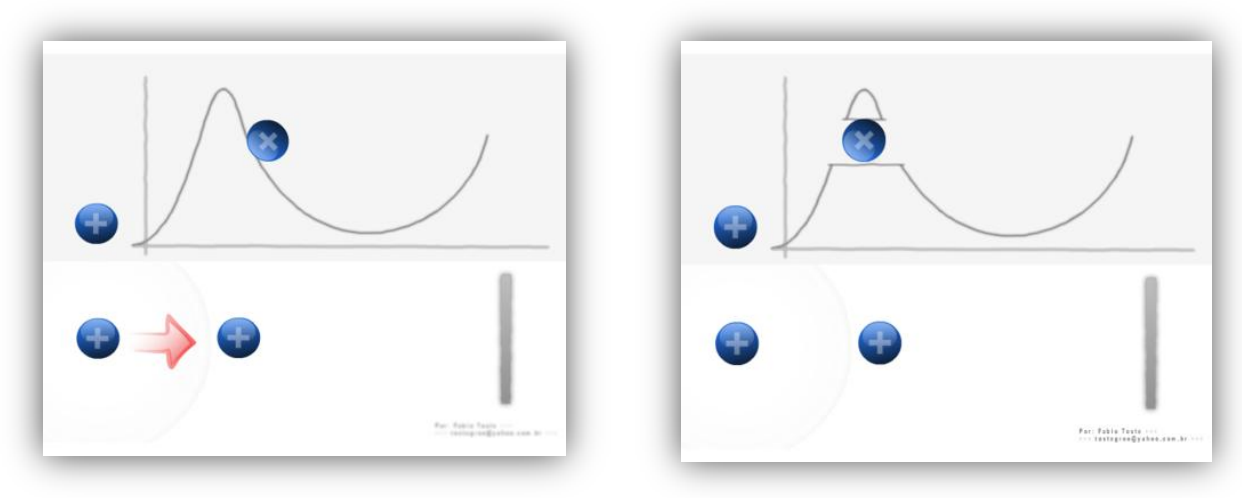

Figura 6.5: Representação do tunelamento

Ainda buscando responder a questão acima, é apresentada a fusão de dois núcleos atômicos e, ao lado, uma balança, que relaciona a massa dos núcleos antes e após a interação nuclear. É apresentada no título desse slide a equação $E=m c^{2}$ que remete à explicação encontrada na física para a diminuição da massa de um núcleo com a liberação de energia nos processos na reação nuclear. 


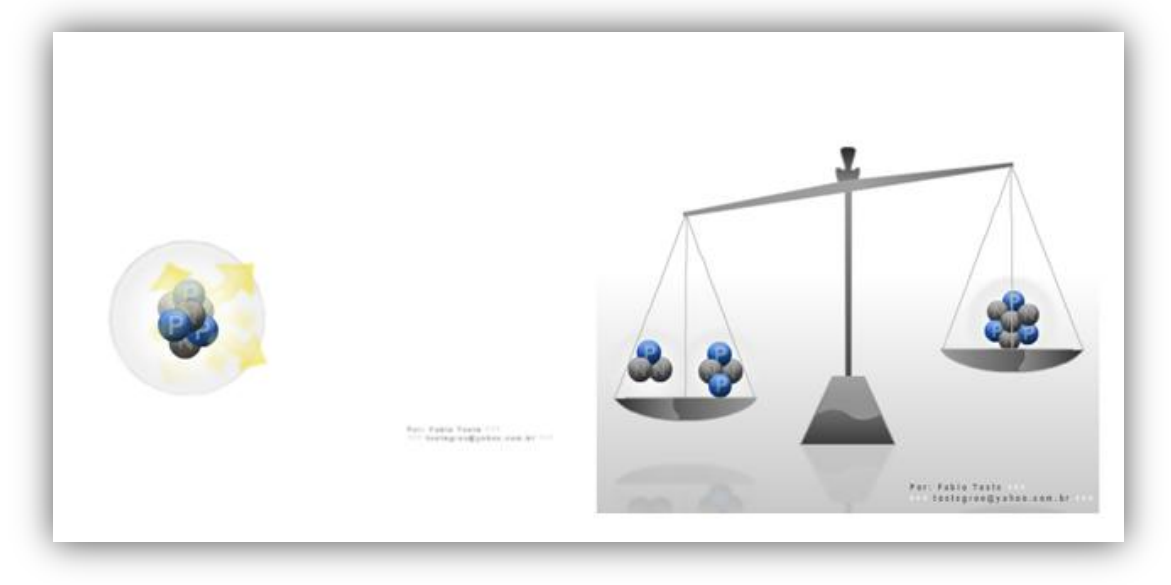

Figura 6.6: Fusão Nuclear

O segundo momento é finalizado com uma lista de algumas aplicações tecnológicas da física nuclear:

- Irradiação em amostras biológicas;

- Identificação química em peças arqueológicas;

- Regeneração das moléculas de DNA;

- Relação estrôncio-cálcio

O terceiro momento inicia com a pergunta: Como podemos estudar $e$ desenvolver aplicações com o núcleo? Em seguida, aparece uma animação onde é apresentada uma caixa que é destruída e reconstruída na tentativa de se fazer uma analogia à atividade experimental.
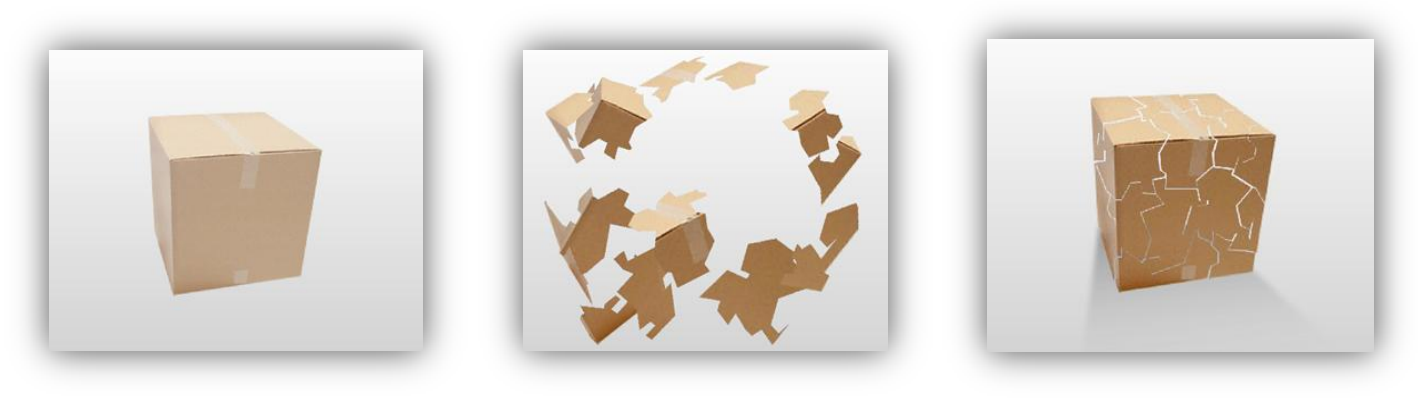

Figura 6.7: Atividade Experimental - Analogia

Segue-se outra questão: Mas... como colidir núcleos? Essa pergunta é respondida com a frase: aumentando a velocidade dos núcleos (acelerando) através 
dos aceleradores de partículas. Nessa parte há uma breve explicação sobre o que é um acelerador: São equipamentos capazes de fornecer energia a feixes de partículas eletricamente carregadas, aumentando sua velocidade através de campos elétricos. E é feita uma nova questão: Como funciona o Pelletron-Linac?

Aparece no mesmo slide um átomo recebendo um elétron em sua órbita e ao lado duas frases curtas: $O$ átomo é neutro e para sentir a força elétrica o átomo é ionizado. Na parte seguinte, que finaliza a apresentação, há uma animação de uma representação do campo elétrico retirando um elétron de um átomo e a relação entre força elétrica e a segunda lei de Newton ( $\mathrm{F}=\mathrm{ma})$.

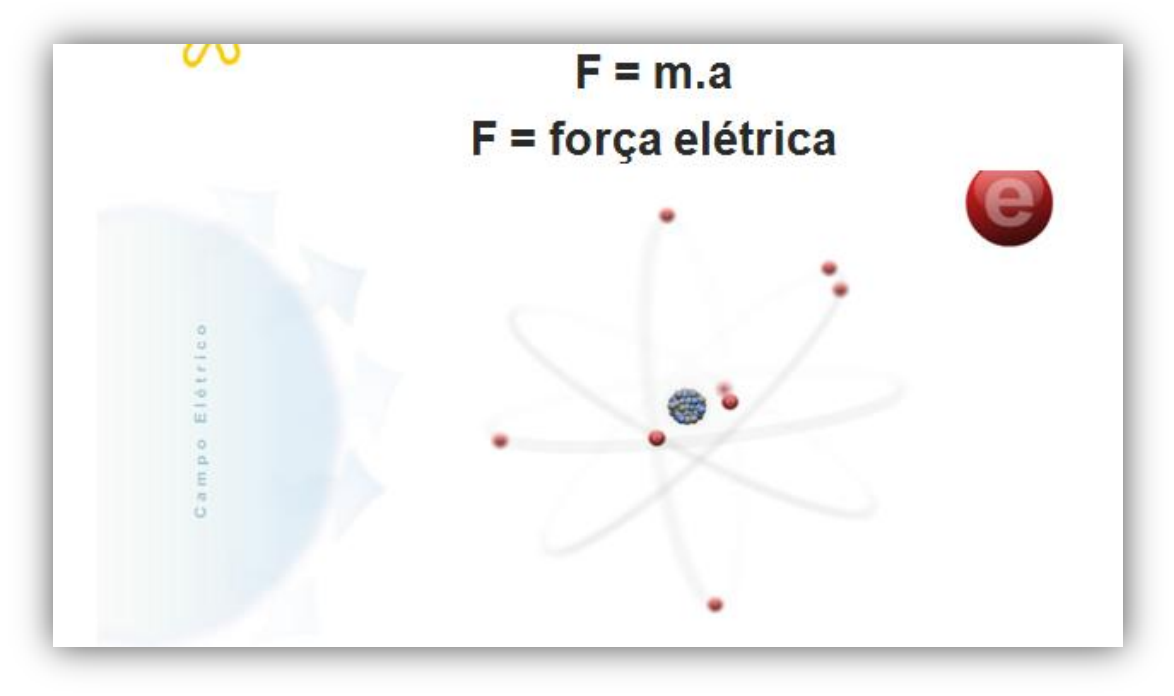

Figura 6.8: Força elétrica

De modo geral, a apresentação multimídia se concentra nas questões da física nuclear para discutir os temas referentes ao contexto das pesquisas, dando ênfase às questões teóricas. A ordem das perguntas segue uma linha de raciocínio que, em um primeiro momento, pressupõe clareza para os estudantes. Seguindo tal ordem descrita abaixo:

- Que tipo de conhecimento queremos obter?

- Do que são feitas todas as coisas?

- Por que o núcleo não se desfaz com a repulsão dos prótons?

- Quantos prótons e nêutrons nós podemos "combinar" para formar um núcleo?

- Qual o formato de um núcleo? 
- O que acontece se atirarmos um núcleo contra outro?

- Como podemos estudar e desenvolver aplicações com o núcleo?

- Mas... como colidir núcleos?

- Como funciona o Pelletron-Linac?

É possível perceber que há uma tentativa de se olhar para a construção da apresentação como um conhecimento que é adquirido de forma linear, cuja compreensão teórica dos conteúdos abordados dá passaporte para o entendimento dos processos envolvidos no laboratório, sejam eles, técnicos, experimentais e teóricos. Em última instância estão as aplicações desses estudos, dando a falsa impressão de que a ciência aplicada não pode gerar a ciência básica ou teórica.

Mesmo quando abordados os processos de aceleração dos átomos no laboratório, o enfoque teórico predomina na explicação, que dá preferência aos fenômenos conhecidos também dos contextos escolares, e sem uma aproximação, de fato. com o aparato tecnológico capaz de criar as situações imaginadas no plano intelectual.

Assim, uma possível forma de se construir um diálogo entre o conhecimento teórico e experimental é a introdução do próprio aparato técnico como elemento de contextualização do fenômeno estudado, trazendo discussões sobre o sentido de diversos andares, a organização dos técnicos na construção de cada parte desse sistema e as questões que são também criadas por esses profissionais. Buscar através dessas perguntas, demonstrar o papel da aplicabilidade como instrumento de transformação da ciência e como, dentro do conhecimento científico do laboratório, não há um limiar claro entre o que se considera aplicado e básico.

\subsubsection{Protótipo 0,33 UD: o modelo do terminal de aceleração}

O protótipo do terminal de aceleração do Pelletron foi desenvolvido pelos técnicos do laboratório de eletrônica do departamento. Esse projeto tinha como finalidade primeira ser uma máquina que pudesse testar alguns componentes (resistores, indutores), antes de serem utilizados diretamente no acelerador. Com o início do projeto atrelado à iniciação científica em 2007, foi feita uma parceria com esses profissionais para desenvolvermos condições favoráveis para sua utilização 
nas visitas. Essas alterações incluíram, por exemplo: introdução de amperímetro, para que os estudantes pudessem visualizar a mudança da corrente induzida no terminal, tal como ocorre no verdadeiro, envolver o protótipo com material translúcido, para que os visitantes pudessem compreender o processo de indução de carga, utilização de material condutor (lâmina de papel alumínio) para se observar, indiretamente, que existe um campo elétrico sendo gerado, ao passo que a lâmina se movimenta quando é ligada a correia, etc.

Essas modificações tinham como intuito apresentar aos visitantes, de modo simplificado, o funcionamento da máquina, desmistificando a necessidade de um conhecimento refinado para compreender como se aceleram os átomos. Assim, o tamanho do protótipo, de aproximadamente 1,5 metros, também se mostrou viável para que os visitantes pudessem ter uma noção do todo, possibilitando dimensões mais acessíveis para a compreensão do acelerador.

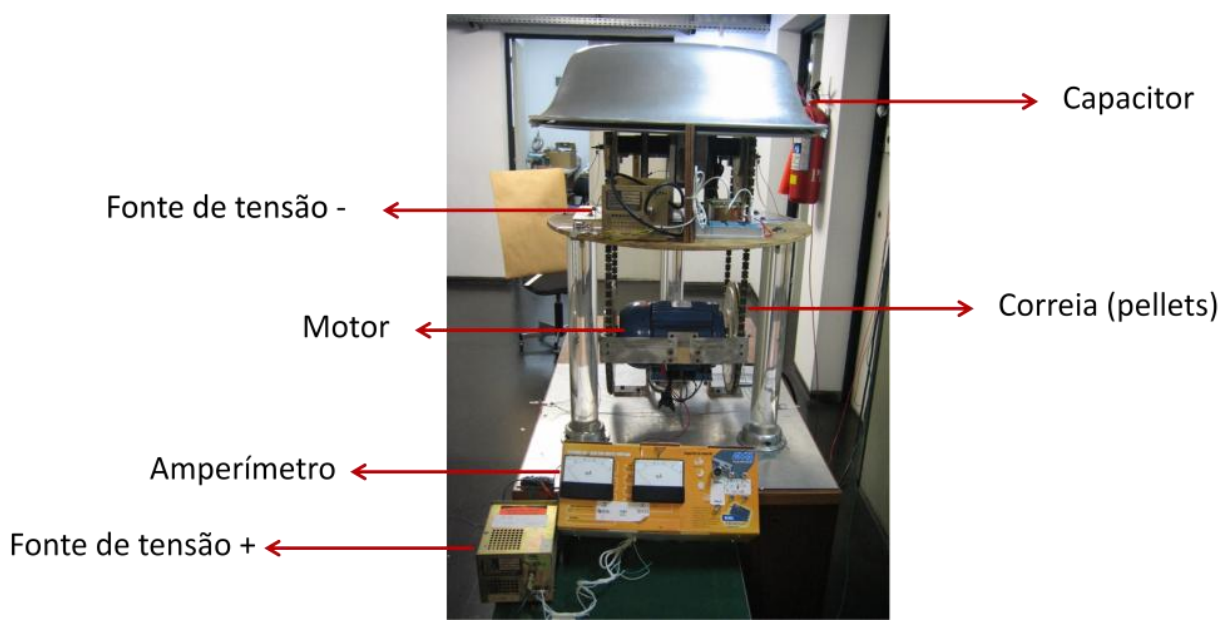

Figura 6.9: Protótipo 0,33 UD

De modo geral, o protótipo que imita o terminal pode ser observado como um sistema que possui um motor, que faz uma correia se movimentar, e um gerador de tensão, que possui a finalidade de promover a indução das cargas nos pellets e assim, gerar uma corrente. Essa corrente por sua vez, passa por um fio ligado a um capacitor que, ao receber essas cargas, carregam o capacitor (bacia) gerando um campo elétrico. Batizado de 0,33 UD, pois se refere a $33 \%$ de 8 unidades do Pelletron, o protótipo é, de maneira simplificada, uma tentativa de apresentar os principais elementos que constituem o funcionamento do acelerador. 


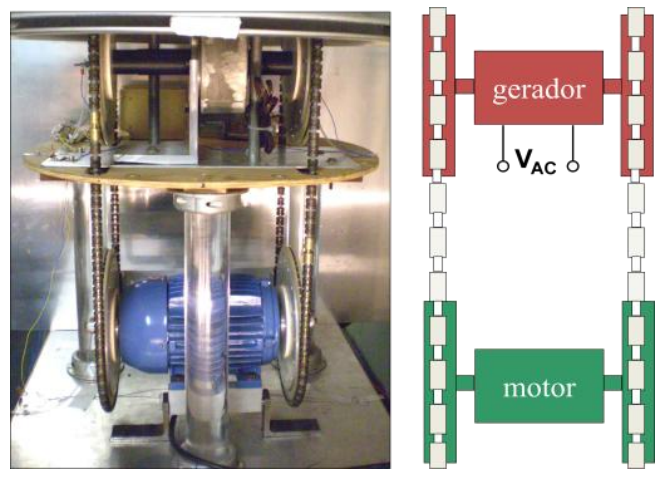

Figura 6.10: Esquema da Correia no 0,33 UD

No decorrer do processo, em paralelo às modificações que consideramos de cunho mais didático, também foram desenvolvidas algumas mudanças técnicas voltadas para o aprimoramento desse aparato. Foi introduzida uma nova fonte de tensão $\left(\mathrm{Vc}_{2}\right)$ de $400 \mathrm{kV}$ (gerador), para promover uma indução de cargas negativas no indutor próximo a polia superior, a fim de auxiliar na indução de cargas no terminal.

De forma geral, o protótipo pode ser considerado uma forma simplificada de compreender os processos técnicos que envolvem o terminal de aceleração, principalmente pela dificuldade em se observar o todo do sistema, quando se visitam os andares do acelerador. Ele tem a finalidade de introduzir ao público questões consideradas de cunho estrutural, pois demonstra de forma mais clara como ocorre o processo de aceleração. O termo "clara" que utilizamos aqui se refere ao olhar o todo, sem o emaranhado e complexo sistema de fios e medidores, que geralmente são acoplados à máquina original, e que, em certos momentos, geram confusão em relação a um entendimento mais primordial do funcionamento desse sistema.

No entanto, para que haja esse entendimento, não basta apenas um material transparente ou a observação de medidores de corrente, pois a contemplação por si só não descortina determinadas dúvidas sobre o que se observa. Mesmo quando se acoplam amperímetros para que estudantes possam observar ou interagir com a máquina, o processo não pode ser feito de maneira aleatória e sem uma discussão sobre as dimensões experimentais que dão subsídios para o entendimento do complexo fazer científico no acelerador. 
Para isso, é importante o diálogo com os especialistas e a constante inferência entre o objeto original e seu protótipo, salientando no pequeno o que se deve priorizar ao olhar para o grande. Nesse contexto, mais do que observar, 0 processo de conhecimento passa pelas dimensões do fazer científico e como essas relações entre o que é técnico e o que é científico se misturam para promover a ciência. Implica então que o protótipo pode ter mais que um papel de demonstrar, mas também de instigar discussões sobre a intrínseca relação entre a tecnologia e a ciência.

\subsubsection{Apresentação de uma visita com professores da escola básica}

A visita foi analisada através de um vídeo, gravado em julho de 2011, com professores-visitantes que participavam de um curso no Encontro IFUSP-Escola ministrado por um docente do Instituto de Física. A pedido do mesmo, foi inserido na programação desse curso uma visita ao laboratório Pelletron sob a tutela de um cientista do laboratório. O responsável pela visita é professor do Departamento de Física Nuclear e atualmente coopera com pesquisas em outros institutos da universidade, com ênfase na formação de professores. Promove cursos de atualização em conteúdos modernos de física e produz materiais para sala de aula com temas sobre física nuclear e aceleradores de partículas.

O grupo de cursistas que participou da visitação é bastante heterogêneo, com alunos de graduação, professores das escolas públicas e privadas; de diversos lugares do Brasil como Rio de Janeiro, Bahia, São Paulo, Pernambuco, etc. No geral, a formação acadêmica desses profissionais era em Ciências Exatas, nas áreas de licenciaturas e bacharelados em: Física, Química ou Matemática. O perfil de idade era de 19 a 60 anos e com período de experiência em sala de aula entre 1 ano e 25 anos.

Para análise do vídeo, a visita foi dividida em cinco momentos, onde o responsável por apresentar o Pelletron mostrou para os cursistas uma palestra e os andares a serem conhecidos. Nessa divisão, o primeiro momento refere-se à fonte de íons; no segundo momento, os cursistas conheceram o terminal de aceleração nos $3^{\circ}$ e $6^{\circ}$ andares onde fica localizado o tanque; no terceiro momento, o grupo conheceu a parte final de aceleração do feixe no andar térreo (ME-200); no quarto 
momento, acontece a interação dos participantes na sala experimental e, finalmente, no quinto momento, apresenta-se a sala de detectores.

É importante salientar que o seminário proferido pelo cientista não foi analisado, pois a autoria do material utilizado foi do próprio palestrante, e, portanto, diferente do proposto por esse projeto. No entanto, de maneira geral, a apresentação se pautava em aspectos técnicos do acelerador e mostrava alguns gráficos relacionados à energia de feixe e ao potencial do tubo acelerador; com diversas fotos de partes do maquinário. Também foram comentadas algumas aplicações dos estudos feitos no laboratório.

No primeiro momento, na fonte de íons, o cientista inicia a fala lembrando que a máquina está em manutenção e, portanto, os visitantes poderão ver alguns elementos do acelerador em seu interior. Assim, o pesquisador mostra, com a ajuda de uma ponteira laser, o aparato que produz o feixe de átomos, indicando que existe um aparelho que gera o campo magnético para deixar o feixe organizado. Demonstra uma válvula que fecha automaticamente, mas lembra que, no começo do funcionamento do Pelletron, ela era fechada manualmente e, em seguida, mostra o medidor de vácuo. Seguindo a trajetória com o laser, o cientista apresenta o ME-20, explicando que sua finalidade é modificar a trajetória do feixe para a vertical. Também mostra o tubo por onde viaja o feixe.

Enquanto alguns visitantes tiram fotografias, outros acompanham 0 pesquisador até uma mesa, onde estão dispostas algumas peças que serão trocadas na fonte de íons. O pesquisador mostra alguns pellets que fazem parte da correia do terminal e apresenta o tubo de pré-aceleração, indicando que "devido ao vácuo ser $10^{-8}$ toda a vedação deve ser feita com um fio de alumínio e deve ser apertado" para garantir que não entrará ar no sistema. Os professores aproximam para olhar as peças mais de perto, mas não fazem questões ou comentários para o cientista.

No segundo momento, no 6ำ andar, o cientista inicia a discussão explicando o processo de retirar o gás ionizante do sistema, onde inicialmente se "faz vácuo para tirar o resíduo do gás, põe ar, retira o ar, depois ele pode entrar!" ao ser indagado se o gás era tóxico o pesquisador explica que já entraram rapidamente no terminal e 
saíram "grogues" devido à toxicidade do mesmo. O pesquisador explica que esse gás é isolante e como a máquina está em manutenção é feito vácuo em uma noite inteira e somente no outro dia é inserido o gás no terminal para que a máquina esteja preparada para se fazer o experimento.

Um dos professores questiona se o feixe desce linearmente pelo tubo ou se chega a rotacionar dentro da tubulação. O cientista explica que ele vem reto e que é posicionado desde a fonte de íons com dipolos para que o feixe passe no centro da canalização. O pesquisador, ao ser questionado sobre a espessura da canalização, explica que a feixe possui cerca de dois milímetros, mas a canalização é grossa se comparado ao feixe. Ele explica que, no entanto, o feixe vai abrindo e que os quadrupolos possuem a tarefa de "fechar" o feixe.

O terceiro andar visitado, os professores podem ter acesso ao tanque do terminal de forma integral. O comentário de um dos visitantes é que o acelerador é "gigante". Nesse andar o pesquisador não faz uma apresentação. Ele é questionado sobre a trajetória do feixe e explica que ele vem sendo acelerado desde o 8a andar, mas sofre a maior aceleração no tanque. O cientista chama atenção para a bomba iônica e explica que não é fácil fazer vácuo e é necessário retirar, em diversas partes do acelerador, o gás residual. Os professores se dispersam para ver as outras partes do tanque.

No andar térreo, que se refere ao terceiro momento, os professores visitam o ME-200. Um dos visitantes questiona a necessidade de um eletroímã para desviar novamente o feixe em relação a um alvo que pudesse estar disposto no final da canalização, na vertical. O pesquisador explica que o feixe utilizado pode ser um óxido de ferro misturado "com outra coisa", assim, o campo magnético tem a capacidade de separar essas "outras coisas", que não são desejáveis na colisão. Assim, o cientista explica que o eletroímã separa as energias dos feixes, pois o feixe inicialmente negativo sofre uma troca de carga no stripper e pode ficar "duas vezes, três vezes, quatros vezes positivo". O que o ME-200 faz é separar os estados de carga para saber a energia e "quando chega no ME-200 é perdido bastante feixe; mas só chega o feixe com energia absolutamente certa”. O professor comenta que o processo é engenhoso e o pesquisador concorda. 
No quarto momento, o grupo conhece a sala experimental, nessa ocasião o pesquisador inicia a apresentação salientando que a precisão utilizada no acelerador é muito grande. Em seguida, é apresentada a região de controle do quadripolo e dos dipolos. O pesquisador explica que antigamente o controle da fonte de íons era feita na sala manualmente, mas que agora não sabe onde está sendo feito. Ele lembra que a sala era totalmente coberta de aparelhos e que, na media em que os controles vão ficando mais modernos, vão diminuindo os tamanhos e sumindo alguns painéis. Explica que há um micro que faz o controle automático da operação a máquina, e lembra que se fazia o controle na mão, na época que trabalhava como aluno no laboratório.

Além dos controles da máquina, o pesquisador também explica que a recepção dos dados é feita pela sala experimental, aonde chegam através dos detectores sinais que são amplificados e decodificados pelos computadores. Nesse momento, um dos professores pergunta para o cientista se o feixe vem acelerado $\mathrm{e}$ que ele tinha comentado que havia alguns detectores no térreo e, portanto, se haveria alguma colisão. O pesquisador explica que o feixe irá interagir com o núcleo alvo que é colocado dentro da câmara de espalhamento e comenta que é preciso que esse alvo seja uma folha extremamente fina.

A finalização da visita é feita na sala de experimental - o quinto momento - 0 pesquisador apresenta algumas câmaras de espalhamento e explica a localização dos alvos e onde ocorre a colisão dos feixes. Um do professores faz a seguinte questão: Professor vou fazer um pergunta bem, bem simples. Qual o motivo, por exemplo, que se usa um aparelho desse e pode trocar vários materiais né? Pode trocar várias folhas e qual o motivo para, qual o sentido, a razão para fazer essa experimentação?

O pesquisador explica: Para entender uma interação você tem que fazer hipóteses, então você faz uma hipótese e testa em um material. Mas se é uma hipótese verdadeira de uma forma geral essa mesma hipótese tem que ser válida para diferentes situações.

Professor: Ah entendi, vocês encontram um padrão! 
Pesquisador: Isso, então a gente tem que fazer sistematicamente com diferentes materiais e o que se conclui é que os núcleos podem ser representados por um tipo de teoria para uma determinada região... de núcleos, na tabela de nuclídeos.. Os núcleos bem levinhos podem ser explicados de uma forma, os núcleos médios são explicados de uma forma um pouco mais sofisticada, os núcleos maiores são mais sofisticados ainda e assim vai. Não é que existe uma única teoria para explicar todos os tipos de núcleos, mas a gente vai estudando sistematicamente para ver qual é a teoria mais adequada para aquele caso particular.

Professor: Ela contribui para aquela carta de nuclídeos?

Pesquisador: Contribui, contribui de uma certa forma.

Professor: Ah, então seria aquela questão sobre o que se sabe sobre aquela curva da carta?

Pesquisador: A curva de estabilidade mostra que quanto maior é o núcleo, mais nêutrons tem que ter, e a gente estuda os núcleos bem pesados para estudar se a teoria vigente vale para qualquer um daqueles isótopos; e tem alguns casos que descobrem isótopos e dessa forma contribui para completar aquela tabela.

Professor: Então aqui pode-se até descobrir novos isótopos?

Pesquisador: Ah, hoje em dia acho que já foi quase tudo né? [risos]Eu li um de 108, 109 e pensei: Nossa que enorme!

\section{Professor: Mas tem vida muito curta!}

Pesquisador: Sim, ele existe e logo decai! Mas ainda bem que existe sempre coisa para a gente estudar, senão não tinha mais emprego!

Ao término, o pesquisador agradece pelas discussões e os professores são convidados a trazerem seus alunos para o laboratório. Alguns professores ainda continuam no laboratório tirando fotografias enquanto outros se despedem do cientista. 
A visita analisada apresentou indícios de dificuldades de interação entre cientistas e visitantes. Alguns aspectos mostraram que termos técnicos utilizados na fala dos profissionais que trabalham no laboratório prejudicam a interlocução com o público. Mesmo quando esses visitantes são profissionais que, de certo modo, já reconhecem alguns aspectos relacionados à terminologia científica, falta em algumas ocasiões segurança a eles para promover um debate sobre determinados assuntos com os pesquisadores. Não lhes é possível assimilar tantos elementos e tantos aspectos em um intervalo de tempo tão curto.

Isso aparece, por exemplo, quando o cientista apresenta alguns elementos ou componentes da máquina que estão relacionados à produção do vácuo. Os visitantes, apesar do iminente interesse sobre o assunto, mostram-se inseguros para fazer questões, apesar de alguns deles buscarem contato com as peças e procurarem indicações na etiqueta sobre informações.

Também é observado que existe um interesse por situações que envolvem as dimensões espaciais da máquina, como o tamanho da tubulação, ou dados, que de certa forma, não são apresentados para o público, como a toxicidade do gás isolante. Apesar de serem questões dispersas, elas nos mostram que, mais do que reconhecerem o processo teórico de aceleração dos átomos, os visitantes parecem se interessar por situações mais abrangentes desse fazer, que se direcionam para situações consideradas menos importantes nesse processo.

Outro fator que chamou a atenção foi a ideia pressuposta do cientista de que o sentido de se fazer o experimento era tácito aos visitantes. Assim, em nenhum momento foi introduzida a discussão sobre o motivo de se construir essas máquinas. As informações durante a visita se pautaram na tentativa de tornar claro como o acelerador funcionava em termos técnicos. Foi, no entanto, na parte final da visita que isso ficou exposto na fala de um dos cursistas ao questionar o sentido de fazer tal experimento.

Esses fatores nos levam a crer que o papel dos materiais de apoio podem ser importantes meios de mediação nas visitas monitoradas. Quando apresentados de forma a respeitar a singularidades de cada cientista, podem salientar alguns 
elementos que merecem destaque nas apresentações e, ao mesmo tempo, serem capazes de promover discussões com o público.

Também, a partir da fala dos visitantes, mais do que apresentar questões de cunho somente técnico ou teórico, há uma demanda em se compreender questões epistemológicas e sociais da ciência. Essas perguntas, no entanto, devido à dimensão menos pragmática da linguagem científica, se mostram mais requisitadas pelo público, possibilitando diálogos com os cientistas. Mas, ainda que isso ocorra, há de certa maneira, uma necessidade de abranger essas discussões para outras instâncias da ciência como a dimensão do fazer científico, sua construção no campo teórico e experimental, o papel da tecnologia e dos técnicos nessa produção, etc.

\subsection{O olhar dos professores e alunos para o que é apresentado sobre o laboratório.}

Na primeira parte desse capítulo nos propusemos a apresentar as estratégias que foram desenvolvidas ao longo dos últimos anos para trazer o público ao laboratório Pelletron. Agora, apresentaremos como os visitantes, em contato com algumas dessas situações, trouxeram subsídios para melhor entendermos os impactos e possíveis sentidos que estão sendo atribuídos por essas pessoas ao entrarem em contato com esse material.

Os visitantes que já passaram por esse laboratório, cerca de 500 nos últimos dois anos, não representariam nada para esse trabalho se não houvesse, para elas, algo significativo que tenha ficado dessa interação. No entanto, devido às dificuldades de se manter contatos mais próximos com todo esse público, apresentamos uma pequena parcela desse universo com a intenção de compreendermos de forma um pouco mais clara, quais as dificuldades, os sentidos das visitas e as maneiras de melhorá-las no intercurso desse projeto.

São, portanto, três grupos que analisaremos para esse trabalho: dois de professores da escola básica e outro de alunos do ensino médio de uma escola pública. No primeiro e segundo grupos, utilizamos a estratégia de grupo focal e análise de material para discutirmos algumas implicações das visitas no contexto escolar. No terceiro grupo utilizamos a ferramenta questionário para 
compreendermos os sentidos atribuídos pelos estudantes após a visita ao acelerador. Apesar das limitações das ferramentas e dos próprios dados, esperamos resgatar indícios para melhorar e compreender a maneira como está sendo recebida a ciência no contexto de sua produção.

\subsubsection{Material produzido por professores da escola básica}

O curso do VI Encontro IFUSP-Escola", de 40 horas, intitulado "Física Nuclear e Física de Partículas: uma abordagem através dos aceleradores de partículas", ministrado por professores do Instituto de Física e alunos do programa de PósGraduação Interunidades em Ensino de Ciências da USP, foi realizado entre os dias 15 e 19 de janeiro de 2010, nos períodos matutino e vespertino, contando com a participação de 37 professores da rede estadual e particular.

Como forma de delimitar os assuntos tratados no curso, optou-se por dividi-lo em dois grandes blocos. No primeiro, buscava-se discutir os aspectos de natureza científica, no segundo, a intenção foi promover espaços de reflexão e discussão a respeito das questões educacionais (elementos a serem considerados na elaboração de propostas temáticas). No primeiro momento, foram desenvolvidas aulas de física moderna, realçando as questões provenientes do próprio acelerador. Também foram promovidas palestras, dentre as quais cabe ressaltar a presença de um dos autores do caderno da Nova Proposta Curricular do Estado de São Paulo. Essas discussões iniciais tinham como objetivo dar subsídios aos professores para elaborarem uma proposta de aula, tendo como tema central o acelerador de partículas.

O primeiro dia foi iniciado com uma breve exposição sobre os aceleradores de partículas e uma contextualização histórica do tema. No período da tarde, os professores tiveram aulas no Departamento de Física Nuclear. Na primeira aula o tema discutido foi "Estrutura Nuclear e Forças" e na segunda aula "Reações Nucleares".

\footnotetext{
${ }^{5}$ O Encontro IFUSP-Escola oferecido pelo Instituto de Física da Universidade de São Paulo é coordenado pela Comissão de Cultura e Extensão desde 2007. Este projeto busca trazer para a universidade professores da rede pública com o intuito de valorizar a atuação docente através de trocas com os pesquisadores.
} 
No segundo dia, no período da manhã, os professores assistiram à palestra "Objetivos/Obstáculos no Ensino de Física Moderna", ministrada por um dos autores da Nova Proposta Curricular do Estado de São Paulo. Nesse momento, puderam dialogar sobre as finalidades e importância da inclusão de física moderna no ensino médio. No período vespertino, os professores assistiram à terceira aula do bloco de física dos aceleradores "As pesquisas no Acelerador Pelletron" e, no segundo momento, conheceram as dependências do laboratório nos moldes das visitas monitoradas ao acelerador.

No terceiro dia de curso, iniciou-se a discussão sobre a abordagem CTS (Ciência-Tecnologia-Sociedade), pautada nos trabalhos de Strieder (2008), Auler et. al. (2009) e Santos (2008) e sobre a Abordagem Temática (DELIZOICOV, ANGOTTI e PERNABUCO, 2002). Neste momento, os professores foram convidados a produzir uma proposta centrada no tema "aceleradores de partículas" para que , posteriormente, fosse apresentada no curso. Na parte da tarde houve a quarta e quinta aulas sobre os conceitos de física, intitulados "Aplicações da Física Nuclear" e "Física de Partículas".

Com o intuito de fornecer subsídios aos professores na elaboração de suas propostas, na sexta aula foi apresentada uma maneira de organizá-las a partir de temas, tomando como referência os trabalhos discutidos anteriormente, em especial considerando a organização temática e conceitual. A partir disso, os professores em grupo produziram uma proposta que foi apresentada e discutida no último dia de curso.

Para a elaboração e apresentação das propostas os professores tiveram como recursos: projetores, computadores e vídeos. Os seis grupos que apresentaram as propostas de aula (Anexo I) foram apenas orientados a considerar a temática "Acelerador de Partículas" e os elementos das organizações temática e conceitual que elaboraram. Segue uma breve descrição das propostas elaboradas e apresentadas pelos professores.

O grupo 1 (G1), constituído por três integrantes, sendo um aluno de graduação e os demais professores da rede estadual, priorizou em sua aula aspectos conceituais, dando ênfase nas questões de aplicabilidade da ciência. A 
proposta contava com seis aulas que versaram sobre vários aspectos e incluíram a visita ao acelerador Pelletron. Na apresentação, os autores não citaram a série em que poderiam aplicar o curso.

O grupo 2 (G2) com dois alunos de graduação e um professor recente da rede estadual, propuseram uma sequência didática para os alunos da $3^{\circ}$ série do Ensino Médio, no $3^{\circ}$ ou 4ํㅡㄹ bimestre. A abordagem escolhida priorizou as questões sociais e os conceitos relacionados à Física de partículas. Os autores também citaram a nova proposta curricular do estado de São Paulo como material a ser utilizado, em conjunto à temática e à visita ao acelerador Pelletron.

O grupo 3 (G3), composto por 4 professores do ensino médio da rede estadual sendo dois professores experientes e dois recém contratados, propôs 6 aulas focadas em conteúdos de Física para alunos da $3^{\circ}$ série, com ênfase em radioatividade. Também inseriram as visitas ao acelerador Pelletron e fizeram de maneira sistemática as organizações temáticas e conceituais. A organização temática foi dividida em três blocos: 1. Pelletron e a ciência, onde os autores, as pesquisas e tecnologias associadas ao acelerador são discutidos; 2. Pelletron: fatores econômicos, sociais e políticos, priorizando as questões de investimentos; 3. Pelletron e a História: que aborda os interesse e necessidades da pesquisa nuclear e suas questões históricas. Na organização conceitual foram três as principais questões a serem trabalhadas: 1. Elementos radioativos; 2. Problemas e consequências e 3..Utilização e aplicação

A proposta do grupo 4 (G4), constituído de 2 alunos de graduação, sem experiência em sala de aula, foi um estudo de caso a ser solucionado pelos estudantes. O grupo contava com um professor da rede estadual e dois alunos de pós-graduação do IPEN (Instituto de Pesquisas Energéticas e Nucleares) que fizeram o curso por já atuarem como docentes e não terem formação pedagógica. Os autores não especificaram a série a ser trabalhada e introduziram a visita ao acelerador Pelletron no programa de aula. O estudo de caso proposto foi a construção de um acelerador de partículas em uma pequena cidade do interior. Nessa proposta, os alunos devem levantar questões sobre os riscos e benefícios da instalação desse laboratório. A decisão tomada pelos alunos também deve se pautar 
nas questões econômicas e políticas que envolvem a cidade, segundo os autores da proposta. A figura abaixo mostra a sequência proposta pelo grupo.

O grupo 5 (G5) tinha como integrantes 3 professores mais experientes do ensino médio, todos com mais de 15 anos dando aula na rede estadual. A abordagem proposta foi um conjunto de dezesseis aulas para a $3^{\circ}$ série, no $3^{\circ}$ Bimestre do ensino médio. Os autores propuseram uma discussão interdisciplinar entre Biologia, Química e Física (prática já implementada na escola de um dos integrantes).

O grupo 6 (G6), com dois alunos de graduação sem experiência na prática docente e um professor recém contratado da rede estadual, propôs aulas utilizando esquemas muito próximos aos mapas conceituais. Os integrantes dessa equipe eram alunos de graduação e professores do ensino médio. O foco da abordagem foi conceitual, utilizando o acelerador Pelletron como ponto de partida para articular diverso conteúdos de Física discutidos no ensino médio. A abordagem foi iniciada com um vídeo demonstrativo do funcionamento de aceleradores de partículas da série "Universo mecânico", seguido de aulas conceituais. As visitas ao acelerador foram consideradas, mas não fundamentais para se abordar o tema proposto.

A partir da análise das propostas apresentadas, é possível constatar que a maioria das equipes (G1, G2, G3 e G6) se pautou nos conteúdos físicos para discutir os aceleradores de partículas e pouco em questões sociais e econômicas. Em certos momentos (como nas propostas de G4 e G5) aparece a preocupação com a motivação dos estudantes em relação ao tema e para isso são destacadas as pesquisas realizadas nos aceleradores, mais especificamente, as que possuem uma relação mais direta com a sociedade.

A análise dos dados obtidos através das propostas elaboradas pelos professores mostra a preocupação dos mesmos com os conteúdos físicos. Todos os professores, principalmente nas equipes que tinham alunos em processo de formação, priorizaram a ciência e suas implicações experimentais.

Cabe salientar que apesar de discutirem e verbalizarem a necessidade de uma abordagem que enfoque todos os aspectos envolvidos do fazer científico e 
suas implicações, poucos professores levaram em conta essas discussões ao elaborar suas propostas. Outro fator que aparece de maneira sistemática nas apresentações é a necessidade da visita ao acelerador Pelletron para que as aulas possam fazer sentido às suas propostas. Nas falas dos professores, a visita é fundamental enquanto elemento motivador para os estudantes, dando mais significado aos conteúdos aprendidos. Neste contexto, parece que só há necessidade de se discutir o tema "Acelerador de Partículas" se houver a visita ao laboratório Pelletron.

Assim, mesmo que o tema seja interessante à primeira vista, todas as discussões priorizaram assuntos associados ao conteúdo da Física nuclear e não necessariamente ao laboratório de pesquisa. Foram poucas as propostas em que se observa a inserção de uma discussão sobre a construção da ciência e muito raramente os processos de desenvolvimento científico. Esse comportamento, possivelmente, se deve à necessidade dos professores em cumprir o programa curricular e à dificuldade em lidar com questões que remetem a um aprofundamento conceitual. Trabalhar questões dessa natureza também requer que alterações no currículo tradicional sejam realizadas (WATANABE e KAWAMURA, 2008). Essas alterações referem-se tanto às abordagens que podem se dar de forma linear, tal como apresentadas nos livros didáticos, quanto aos conteúdos abordados que, na maioria das vezes, seguem uma estrutura rígida, em que os conceitos científicos são tidos como "estáticos e verdadeiros", permanecendo inalterados ao longo da história. Assim, para que propostas diferenciadas sejam incorporadas na escola é necessário que um novo posicionamento frente às questões curriculares seja tomado, em que o cumprimento de programas não seja o único norteador da formação básica.

Mesmo que a proposta apresentada aos professores possibilite outra abordagem dos conteúdos científicos e permita uma discussão mais ampla sobre a ciência, isso parece não ser a preocupação primeira dos professores, já que poucos propuseram discussões sobre questões sociais, políticas e econômicas em suas propostas.

Assim, uma questão que ainda precisa ser discutida, do ponto de vista da formação docente é a necessidade de introduzir abordagens que envolvam 
discussões de cunho mais abrangente e, principalmente, que dê em subsídios para que os professores possam utilizar as temáticas para apresentar uma ciência em seus processos de produção e transformação.

\subsubsection{Grupo focal com professores-visitantes do laboratório}

Os professores participantes do grupo focal fizeram a visita ao laboratório Pelletron no contexto do curso "Superando obstáculos no ensino de física moderna e contemporânea" no Encontro IFUSP-Escola de Julho de 2011. Após conhecerem o acelerador, todos foram convidados a discutirem com o docente do curso algumas impressões sobre a visita.

Foi inicialmente contextualizado que esse momento seria gravado para tomada de dados, objeto de uma dissertação de mestrado. Após o consentimento dos docentes sobre a gravação das imagens e a utilização da fala dos mesmos para análise do trabalho acadêmico, em forma de autorização, foi proposta uma questão para iniciar o debate que tinha como objetivo promover, junto com os professores, uma reflexão sobre momentos ou situações que eles consideraram mais interessantes ou inesperadas e que, de certo modo, poderiam ser melhoradas ou salientadas nas visitas para o público e alunos do ensino médio.

Assim, os participantes do grupo enfatizaram aquilo que para eles poderiam ser elementos a serem agregados para que as visitas fossem mais interessantes ou amplificar algumas situações que eles consideravam mais diferenciadas do conhecimento escolar tradicionalmente ensinado, ou seja, aquele dos livros didáticos ou da aula expositiva. Os assuntos que iluminaram a reflexão dos dados foram: (1) estrutura da visita; (2) conhecimento do professor; (3) viabilidade no contexto escolar do estudante; (4) desmistificação da ciência; (5) sentido do estar no laboratório; (6) complexidade do fazer científico e (7) a visão dos cientistas para as visitas.

De um modo geral, os professores enfatizaram a importância de se introduzir o tema na sala de aula, no entanto, salientaram a necessidade de material disponível para a preparação dos estudantes antes de entrarem no laboratório. Eles acreditam que os alunos, sozinhos, não são capazes de compreenderem ou darem sentido às visitas e, consequentemente, não poderão promover questões ou 
diálogos com o cientista. Para tanto, introduzir os alunos à visita deve estar relacionado com um projeto mais amplo.

"Então como o colega falou, tem que ter um sentido aqui. Você pegar um aluno do ensino médio e tacar lá dentro não vai fazer sentido para ele, apenas depois que ele vai começar a entender, daí quer dizer, uma dúvida que ele poderia ter falado lá, algumas pessoas terem falado do próprio instituto, ele vai deixar e vai perder depois. Então, se ele puder ter uma bagagem já para poder levantar essa dúvida, por que depois acho que... in loco, no próprio acelerador poderia ser mais interessante. Pelo menos para o ensino médio."

“[...] Eu acredito que se tiver um projeto bem estruturado para eles (alunos) é pertinente a presença até de aluno de ensino médio. É interessante de você poder ver né, como o pesquisador trabalha, o trabalho que é feito de pesquisa também. Até para nós também, para quem nunca visitou um laboratório de física nuclear, fica até impressionado com tudo o que tem ali. É bem, bem interessante."

Atrelado a essa necessidade de materiais, também surgiu, na fala dos professores a própria formação continuada e a introdução de temas atuais da área de ciências em cursos de extensão. Nesse contexto, também foram levantadas, na discussão, a importância da interação entre a escola e universidade. Para esses profissionais, conhecer o laboratório possibilita maior segurança para abordar o tema na sala de aula.

“[...] eu não tinha antes, estrutura e capacidade para falar de um acelerador, eu só sabia o que eu tinha lido e agora eu já tenho um pouco, uma visão melhor. Eu já consigo falar de uma forma diferente o que é um acelerador. O que eu vi e da palestra de preparação. [...] Quando os professores estiverem preparados para isso aí você vai ter condições de trazer os alunos."

Outro fator interessante trazido pelos professores é a possibilidade de desmistificar o conhecimento científico para os estudantes. Para eles, mais do que aprender conceitos de física, o laboratório possibilita uma inserção num mundo considerado pelos alunos como inatingível. Ainda nessa linha de pensamento, também surgiu a importância de abranger o entendimento da ciência para 
discussões sobre a complexidade do experimento sem, no entanto, associar isso a uma incapacidade de compreensão. Isso reflete, segundo a fala dos professores, em olhar para a ciência de forma mais viva e em transformação.

“Eu acho que o que está por trás do que eles vão aprender é sim, o obstáculo, o mito que as ciências exatas carregam para o nosso tipo de aluno, por que [..] para ele é meio seleto, que eles vão achar que é um zoológico, um mundo que eles nunca vão poder entrar, né? E é mentira. Então eu acho que antes da gente pensar o que aprender é pensar assim: Como conscientizá-los que eles podem sim aprender; o que aprender, depois, vai ser consequência."

“Uma coisa interessante que eu achei, até mesmo para mim que estudei essa parte de física, um pouquinho de aceleradores, não fazia ideia do tamanho do maquinário, por exemplo, o tamanho do tubo que passa lá, o feixe de cargas aceleradas né? De dois milímetros quase. O ângulo que ele vai ser defletido para fazer o encontro do alvo e tudo o mais. Acho que é uma coisa muito mais rica de você vir e ver como o maquinário é grande e quanta estrutura se precisa para fazer um estudo desse tipo. Acho isso muito rico."

Em relação aos cientistas, os pesquisados enfatizaram a importância de se promover essas interações, dando ênfase na preservação do valor da ciência e de seus agentes como motivador para que outros laboratórios promovessem visitas.

“Também fica a crença de que é um meio seleto né? Fazer visitação na cabeça de alguns é que vira zoológico. E não é a ideia do que eles fazem [cientistas do Pelletron], que eles estão fazendo. É o trabalho deles. Para eles é uma coisa para poucas pessoas, tem a tecnologia de ponta né?"

A partir da fala desses professores, podemos notar algumas percepções sobre o fazer científico que ultrapassam a dimensão conceitual da ciência. Aparece nessas discussões uma preocupação em conhecer os ambientes de trabalho do cientista e como a experimentação aparece, de forma diferente do contexto escolar, nesses espaços. 
Surge, também, um forte vínculo com o conhecimento associado à atuação docente, quando é levantada a necessidade de apoio, seja pelos materiais didáticos ou cursos de formação continuada, para que temas como os dos laboratórios científicos sejam abordados de forma segura pelos professores na sala de aula. Nesse sentido, aparece a importância de se conhecer esse ambiente fisicamente, relacionando essa inserção ao acelerador Pelletron como uma forma de ampliação do saber sobre a ciência.

Quando é olhada essa inserção para a formação do alunado, a visita surge como um instrumento de desmistificação da ciência e possibilita, segundo os pesquisados, uma compreensão sobre a ciência menos estigmatizada. Isso implica em encorajar os estudantes para um envolvimento com esse conhecimento e que, como consequência, haverá ou não, uma aprendizagem sobre esses conteúdos. Parece-nos que, mais do que ensinar conceitos de física, os professores procuram no laboratório, possibilidades de promover um engajamento desses estudantes nas aulas de ciência, mostrando a complexidade e, nem por isso, a incapacidade de compreender o que é feito no acelerador. Assim, o quê aprender deverá ser abordado dentro da sala de aula.

Do ponto de vista estrutural da visita, os professores parecem concordar sobre a relevância dos seminários que iniciam as atividades no laboratório. Enfatizam que tal introdução dos conceitos possibilita que haja maior aprofundamento e segurança para formularem questões aos cientistas, nos ambientes visitados. Ainda, nesse contexto, surgiu na fala dos pesquisados a possível visão dos cientistas sobre a abertura do laboratório para o público. Segundo os professores, a ideia de se acreditar nos cientistas como um grupo seleto e a aversão de alguns em relação a essa interação com o público se refere ao sentido que se dá para esses espaços e que, para esses pesquisados, não se referem a um passeio como em um "zoológico", mas o fato de apresentar o lugar onde esses profissionais trabalham.

As falas dos professores indicaram diversas melhorias para as visitas, deram indícios da inserção de temas mais amplos na visita que não somente o conhecimento teórico. Enfatizaram o papel de se conhecer a complexidade do tema 
e assim, ampliar a visão sobre o sentido da experimentação para os alunos e os próprios professores.

Essas formas de olhar para a visita sugerem a necessidade de se promover espaços dentro do laboratório que possibilitem a abertura de diálogo sobre outras situações vivenciadas no cotidiano do trabalho científico. Esses momentos, que são percebidos nas visitas, com a dinâmica dos funcionários, técnicos e pesquisadores, que estão em constante movimento dentro do laboratório, podem ser salientados com a interação com outros profissionais que também participam desse contexto do fazer científico.

Os materiais didáticos, preteridos pelos pesquisados, também podem vir a se tornarem importantes instrumentos de complementação das visitas, criando possibilidades de intersecção entre o mundo científico e o escolar, mesmo antes de se conhecer o laboratório. No entanto, pensar sobre esses elementos requer uma reflexão aprofundada sobre aquilo que o laboratório busca e a demanda da escola; para então, promover uma proximidade mais legítima com a sala de aula e a própria formação dos professores.

\subsubsection{Percepções dos estudantes da escola básica}

Foi selecionada, para a apresentação referente aos alunos, uma amostra que incluiu uma turma de alunos visitantes, especialmente por terem tido algum tipo de preparação para a visita. Os pesquisados são alunos do $3^{\circ}$ ano do ensino médio de uma escola pública no município de Barueri, na região metropolitana de São Paulo. O contexto da coleta de dados foi caracterizado em um mini-curso, ministrado em 2009, por 3 alunos de graduação como trabalho da disciplina "Metodologia da Física II" da Faculdade de Educação da USP e que faz parte do último semestre da grade curricular do curso de Licenciatura em Física.

Participaram da pesquisa 22 estudantes na faixa etária de 15 a 18 anos, que frequentavam as aulas no período vespertino. Esses jovens vivem em um bairro de classe baixa onde há poucos espaços de intervenção cultural. A escola, no entanto, é considerada pela comunidade de "bom nível" e as dependências são muito bem conservadas pelos alunos e profissionais. O engajamento da diretora com a escola é 
muito respeitado pelos professores e a mesma mobilizou os comerciantes e empresários do bairro para o pagamento do ônibus que levou os estudantes para conhecer o acelerador Pelletron.

O curso intitulado "Também tem cultura nos aceleradores de partículas" tinha 3 aulas de 4 horas, sendo dois sábados na escola e o último no Instituto de Física da USP. Esse dia tinha a finalidade de terminar o curso com a visita ao laboratório. Assim, a coleta de dados aqui apresentada se refere somente a essa visita, quando os alunos foram convidados a responderem um questionário antes e após a visita.

O mesmo procedimento foi feito com outros estudantes, mas que não entrarão nessa pesquisa devido aos contextos acadêmicos distintos (alunos de graduação, alunos de escolas técnicas de cursos de eletrônica e mecânica, etc.) e que, portanto, consideramos que mereceriam uma análise em grupos diferenciados e, no entanto, distantes, nesse momento, do público que esse trabalho quer atingir.

Os questionários analisados foram os respondidos após a visita e tinham como mote resgatar, junto aos alunos, momentos ou situações que eles consideraram mais relevantes na visita. Assim, foram apresentadas aos alunos 5 questões relacionadas ao tema e que poderiam ser respondidas de forma aleatória. No entanto, alguns problemas referentes às questões foram observados após o teste, como a falta de clareza nas perguntas e a dificuldades de desvincular o curso que os estudantes fizeram com a visita ao laboratório. Isso aparece quando os estudantes associam, por exemplo, os experimentos produzidos em sala de aula (no curso) com os experimentos do laboratório.

Em alguns casos, para evitar esses tipos de confrontações na análise de dados, optamos por trazer algumas falas significativas desses pesquisados ao invés de utilizar categorias de análise para jogar luz às nossas reflexões. Essa postura, no entanto, não prejudica os resultados obtidos, pois evoca um refinamento dos dados coletados sem a introdução de ruídos desnecessários (BELLIZIA et al, 2011).

Assim, quando perguntado aos estudantes sobre aquilo que mais eles gostaram ao conhecer o acelerador, obtivemos como respostas: o próprio laboratório 
e suas dependências $(59 \%)^{6}$, o conhecimento teórico associado ao seminário que inicia a visita (18\%), o lanche que foi oferecido na visita (18\%) e a ampliação do conhecimento científico (18\%).

"De ver o Pelletron (acelerador de partículas) e a experiência do isopor. E as palestras sobre prótons, nêutrons, etc."

"Primeiro a comidinha e o acelerador"

"Da sala de comando do acelerador"

"Gostei muito de ver o projeto. Gostei também das experiências. O lanche"

Em relação à ampliação do conhecimento, foi percebido que para quatro estudantes a visita proporcionou experiências, também, dentro e para além do laboratório. Isso apareceu nas respostas:

"Gostei do espaço em que se encontra o Pelletron, um ambiente bom para trabalhar e estudar"

"De tudo, por que ajudou a ampliar o conhecimento científico"

"De conhecer coisas que eu nem imaginava que existia"

"Gostei de conhecer a Instituição (USP) por nunca ter ido a uma universidade"

Em relação aos momentos, considerados pelos estudantes como aqueles que menos gostaram, obtivemos poucas respostas. Enfatizaram, em sua maioria, que haviam gostado de tudo, o que nos remete a uma dificuldade de analisar a questão proposta. Esse tipo de postura pode ser associado ao contexto da coleta de dados, onde os alunos poderiam, de certo modo, ficarem inibidos de escreverem suas opiniões, mesmo que sem identificação, por estarem em um laboratório científico. Mesmo que tal afirmação não seja verdadeira e nos remeta a uma visita que tenha sido efetivamente aceita como interessante pelo grupo, é importante salientar que essa avaliação também está atrelada ao contexto do curso e, portanto, não pode ser

${ }^{6}$ A soma dos dados não dá $100 \%$ pois alguns estudantes deram mais de uma resposta. 
considerada totalmente relacionada à visita ao laboratório. Mas algumas respostas dão pistas de problemas encontrados pelos estudantes.

"No fato de ser sábado, tinha poucas pessoas, gostaria de ver mais gente"

"Foi muito pouco tempo e eu gostaria de realizar mais experimentos"

"Da parte teórica, que foi um pouco cansativa"

Apesar de a ferramenta questionário ser uma fonte limitada e estarmos cientes de que algumas reflexões deveriam ser pautadas em mais confirmações, associadas a outros tipos de coleta de dados, podemos perceber, nas respostas dos estudantes, que há um forte apelo para o papel da visita como uma situação lúdica extra-escola. Isso aparece quando os estudantes reforçam a ideia de que a parte relacionada ao lanche foi uma das que mais gostaram.

Os pesquisados, em sua maioria, citaram que apreciaram o acelerador de partículas sem, no entanto, salientaram os motivos para tal. Um estudante aponta para essa direção, quando cita a sala de controle, como uma parte do laboratório que gostou de conhecer. De modo geral, os alunos reconhecem que a máquina é interessante, mas não associam os conteúdos teóricos com a parte experimental, visto que, ao responderem o questionário, apresentam a palestra e a visita como situações separadas. Em outro caso, salientam a parte teórica (palestra) como sendo algo cansativo. Esses problemas, no entanto, como já mencionados em passagens anteriores são, em geral, da própria concepção da visita e reforça, aqui, a ideia de que os alunos não são capazes de associarem o teórico e o experimental sozinhos.

Quando os pesquisados trazem a falta de tempo e o esvaziamento das pessoas, como uma situação ruim, isso remete a uma necessidade do reconhecimento desse ambiente de forma mais aprofundada e também, de situar esse laboratório em um contexto social. Mesmo que a ideia de se "ver mais gente" esteja associada aos alunos, jovens estudantes da universidade; é interessante observar que são também esses sujeitos que fazem parte do contexto da produção da ciência. Em relação ao aprofundamento do ambiente do laboratório, podemos 
pensar que tal situação pode estar associada, tanto ao conhecimento como a outros espaços do laboratório.

Esse estar na universidade, como cita um estudante, é tão importante quanto o conhecer o Pelletron. Mais do que aprender sobre física, há também, nesses momentos a possibilidade desses jovens em conviver com o ambiente acadêmico, geralmente distanciado na escola básica.

A partir da fala dos estudantes, podemos notar que a visita ao laboratório faz, em sua maioria, parte de um contexto que não condiz com algo relacionado ao aprendizado escolar. Para eles, ir ao Pelletron é ter a possibilidade de conhecer outro lugar, sair da escola e não como uma possibilidade de ampliar o conhecimento científico. Assim, dar sentido para as visitas como espaços de formação científica deve ser uma das prioridades dessas reflexões. Não implica que, para tal objetivo, seja necessário um espaço que simule a escola, mas que busque promover uma reflexão com os estudantes sobre essa inserção no laboratório.

Outro fator importante é a necessidade de se articular o conhecimento teórico e o experimental, de forma mais clara para os estudantes, para que eles possam compreender o papel dos estudos dos laboratórios científicos em um contexto mais amplo, ou seja, entender que a teoria e a experimentação são maneiras de expressão da ciência e que ambas são intrínsecas ao ambiente do laboratório.

\subsection{O olhar dos cientistas para o que é apresentado sobre o laboratório.}

Após a discussão sobre o que foi pensado e apresentado ao público em relação à ciência do laboratório e quais foram as percepções dessas intervenções com professores e estudantes da escola básica, agora focaremos nossas observações sobre os cientistas. Esperamos, nesse momento, trazer algumas reflexões desses profissionais sobre o sentido de se abrir as portas do laboratório para o público, mais especificamente a alunos do ensino médio, e como seus estudos podem ser apresentados a esses estudantes. 
Assim, foram produzidas entrevistas semi-estruturadas com pesquisadores/docentes do laboratório, onde docentes foram convidados, através de e-mails, a discutirem sobre os trabalhos desenvolvidos em seus grupos de pesquisa e os temas relevantes a serem abordados com os estudantes da escola básica. As entrevistas foram feitas com quatro dos seis docentes procurados. A seleção se deu pelas pesquisas por eles desenvolvidas e a disponibilidade dos entrevistados.

Essas entrevistas ocorreram entre o período de 2007 a 2008, no contexto da iniciação científica, quando iniciava a reflexão e a produção do material de divulgação do laboratório. Os pesquisadores participantes ministram cursos na graduação para as turmas de bacharelado e licenciatura em física, sendo que dois deles já desenvolviam visitas no laboratório, de forma não sistemática, para o público em geral. Assim, foi proposta uma conversa com esses profissionais, onde questões centrais foram apresentadas, mas deixando espaço para que os docentes pudessem transcorrer sobre os temas que quizessem, sem sofrerem muitas intervenções durante a fala. As perguntas apresentadas foram:

1. Quais temas seriam mais relevantes de serem apresentados aos estudantesvisitantes no Pelletron?

2. Quais os conteúdos ou temas mais relevantes associados à sua pesquisa que podem ser abordados durante a visita?

3. Quais as formas ou estratégias para se apresentar o tema de física nuclear ou de partículas para os alunos da escola básica que visitam o acelerador?

4. Qual o papel dessas visitas para o laboratório?

Todas as perguntas foram feitas em um primeiro momento, deixando a cargo dos entrevistados a ordem de respostas. Quando algumas das questões não foram respondidas, o pesquisador era lembrado sobre tópicos que ainda não tinham sido abordados. Cabe salientar que alguns desses docentes não responderam a todas as questões. Como a entrevista foi desenvolvida de forma aberta, onde os entrevistados poderiam transcorrem sobre o tema de forma livre, surgiram falas e assuntos da iniciativa dos professores, tornando os dados mais ricos e interessantes. 
Em relação à primeira questão, os pesquisadores assinalaram para conteúdos básicos do ensino médio que podem ser abordados no contexto do acelerador, formas de inserir assuntos sobre suas pesquisas que podem ser discutidos, simplificadamente, com esses visitantes, as relações de cooperação científica nos grupos e a aplicação dos estudos.

[P4] Para os alunos do ensino médio, a informação mestra é a interdisciplinaridade, pois a física sozinha tem sua importância, mas pode ser usada de forma conjunta para atingir um certo objetivo, melhorar nosso conhecimento.

[P4] O que a gente faz aqui, é que há uns anos atrás se interessou por essa interface física-biologia, foi uma coisa interessante que a gente achou e começamos a investir nisso.

[P2] (...) devemos esquecer o átomo, para os pesquisadores ele é grande demais. Então devemos nos ater somente ao núcleo atômico.

[P1] Pensamos então que a física básica não está da maneira que a gente previu, então tem os dois lados, a física básica gerando a aplicada e também a aplicada gerando a física básica.

[P4] (...) estamos aos poucos conseguindo a colaboração com biólogos e isso é muito importante, pois precisamos do conhecimento deles pois não dá para fazer sozinhos sem conhecimento de Biologia e Química.

[P1] (...) você sabe disso junto com os químicos e o pessoal de arqueologia, isso te dá luz de como vai tratar sua amostra, a sua estátua para não perder material.

Em relação à segunda questão, os professores buscaram explicitar os processos de coleta de dados, articulando tal conhecimento com a produção no laboratório. Os pesquisados buscaram situar suas pesquisas no campo científico, sem a preocupação de transpor esse saber aos estudantes, como percebemos nas falas. 
[P1] Aí você tem as características que são interessantes que é estudar filmes finos, estamos falando de angstrom, estamos falando de 10 angstrons, e a ideia é tentar medir a espessura desses filmes e o que tem nesses filmes. Estão esses espectros de energia te dão esse tipo de informação, dá para ver pontinhos que te dão informações de quão fino são suas amostras.

[P4] E medindo essa perturbação tiramos informações sobre a estrutura da molécula.

[P3] Todos esses processos de utilizar as experimentações e aplicá-las as teorias acabam por desenvolver novas equações.

[P4] nós usamos esse conceito de pico de Bragg quando irradiamos as células mas não é no sentido de pensar em ter uma coisa aqui para irradiar, a gente pode dar uma contribuição fazendo essas irradiações ao estudo das irradiações de tumores, isso sim mas a irradiação em pacientes como é feito em alguns laboratórios por aí afora não é possível aqui.

[P1] Você pode autenticar sabendo que é de um determinado pintor ou não, analisando as tintas que ele usava, você pode analisar as tintas pelo método PIXE, você pode analisar sem estragar a obra, vai lá e produz raio-X e aquele amarelo de determinado autor tem aquela composição, por que naquela época os caras faziam suas próprias tintas, misturando uma cor ou uma flor (...) então ele tem um amarelo ou um azul muito característico (...) então é um serviço de autenticação.

[P1] Outro trabalho é medir a profundidade do aço, que geralmente são usados para endurecer superfícies metálicas, algumas empresas que trabalham com aço queriam saber quanto de nitrogênio tinha, isso dá uma ideia de como o grupo lida não só com física nuclear mas com outros espectros.

Em relação às estratégias que poderiam ser trabalhadas com os alunos do ensino médio, apareceu na fala dos pesquisados a utilização de exemplos na construção de modelos. Também surgiu na discussão sobre a importância do laboratório em relação à comunidade científica, procurando diferenciá-lo de outros centros de pesquisa sendo uma forma de mostrar aos estudantes sua importância. 
[P2] Para uma discussão com alunos do Ensino Médio, é sempre interessante construir exemplos concretos dessas utilizações [das pesquisas]. Outro assunto interessante é as formas do núcleo atômico, desmistificando a visão do átomo como uma bolinha e que seu conjunto pode vibrar ou rodar.

[P3] Atualmente poucos laboratórios no exterior trabalham com aceleradores de baixa energia, pois se achava que já havia descoberto quase tudo sobre partículas que se colidiam nesses aceleradores, no entanto, não é bem isso que se observa, pelo contrário, ainda há muito que estudar e por isso os grupos do Instituto têm trabalhado muito, principalmente porque não se conseguem estudar algumas dessas colisões em altas energias.

Em relação à última questão não houve respostas diretas dos entrevistados. No entanto, surgiram temas na fala dos pesquisados que se mostraram interessantes para serem abordados, no contexto do laboratório. Um desses temas é a inserção dos trabalhos teóricos desenvolvidos na comunidade científica.

[P3] Alguns estudos no exterior que utilizam esse modelo acabaram por comprovar com sucesso os dados esperados. Portanto, a intenção é sempre tentar encontrar equações que possam explicar uma grande gama de assuntos e não o contrário. Assim, essas experiências que são desenvolvidas no acelerador podem indicar como podemos chegar o mais próximo dessas equações.

Também surgiu, na fala dos cientistas, dimensões do fazer científico que estão relacionadas a situações inesperadas de determinados resultados.

[P1] (...) então você observa essas coisas malucas. E no oxigênio não vimos diferença, então atiramos em uma coisa e acertamos em outra. Muita coisa desse tipo acontece na ciência.

Outro tema presente na fala dos pesquisados é a necessidade de compreender as pesquisas como básica ou aplicada. Tal dimensão aparece como um problema relevante para os cientistas quando eles procuram explicar os trabalhos que fazem e sem, no entanto, encontrarem uma resposta definitiva para 0 termo. 
[P4] Eu já conversei com várias pessoas e não consigo definir exatamente se ele [trabalho] é básica ou se é aplicada. Eu chamaria de aplicada, mas nossa ideia é tirar informações da básica (...). No fundo é básica.

Em suma, na falas dos pesquisados aparece uma visão sobre a construção do conhecimento que busca medir e avaliar os resultados cuja finalidade já está estipulada, ou seja, já se sabe o que se quer observar. Essa dimensão é interessante, pois mesmo nesse contexto, os cientistas enfocam situações inesperadas que fazem da descoberta algo inusitado em alguns casos.

Em relação à comunidade científica, aparece a necessidade de interfaces com outros saberes da ciência, atrelando tal conhecimento como necessário para a construção do conhecimento no laboratório. Enfocam assim, que o conhecimento experimental por si só não dá conta do desenvolvimento da ciência e a interpretação dos resultados depende de saberes múltiplos.

Finalmente, a compreensão do papel da ciência na sociedade, e suas possíveis contribuições na sociedade, pode ser um importante instrumento de revelação do fazer científico como imerso em um ambiente social não tão distante dos sujeitos que aprendem. Neste sentido, a ciência do laboratório se mostra como parte da comunidade em que estamos inseridos, pois remete a fala dos pesquisados na aplicação das pesquisas do laboratório como assuntos importantes para serem incorporados nas visitas.

O que podemos perceber da fala dos cientistas é que, em sua maioria, há uma preocupação em mostrar aos estudantes os conhecimentos produzidos e as pesquisas a eles associados; que fazem dos trabalhos no laboratório um indicador de qualidade acadêmica pelas suas publicações. Eles também apresentam um interesse por demonstrar a ciência em transformação e que, de certo modo, procura a interlocução com outras áreas do saber.

No entanto, pouco aparece na fala dos cientistas, sobre outras dimensões que não as do conhecimento, que podem ser apresentadas aos visitantes. Para esses pesquisados, o papel das visitas é promover um entendimento de como o conhecimento teórico é trabalhado no acelerador e sua intersecção com a área 
experimental através da aplicabilidade em estudos de cooperação. Assim, as dimensões sobre o fazer científico, os grupos de pesquisa, o próprio cientista e técnicos, desaparecem da fala desses profissionais para evocar o conhecimento como elemento primordial a ser apresentado nas visitas.

A tentativa de promover um diálogo entre essa visão e de sua ampliação para outras instâncias da ciência que podem ser apresentadas em um laboratório é, portanto, um dos maiores desafios desse projeto. Essa postura remete a promover a inserção desses cientistas na interação com o público, buscando, nesses espaços, promover debates capazes de ampliar o conhecimento de ambos para novas concepções do que seja divulgar o conhecimento científico.

\subsection{Um breve relato das experiências vividas no laboratório}

Para finalizarmos a apresentação dos dados, propomos, nessa seção, trazer um panorama sobre as percepções das interações com o corpo técnico do laboratório a fim de dar luz a algumas inferências sobre os dados. Esse momento do trabalho pode ser avaliado como uma mescla de métodos qualitativos, pois evocam a entrada no laboratório (etnografia) e a observação e diálogo com os pesquisados com o intuito de promover uma reflexão sobre o trabalho (pesquisa-ação).

Essa opção por apresentar nossas percepções se mostrou relevante, pois seus dados são reveladores sobre os sujeitos que participaram da pesquisa, ao trazerem: questionamentos em interações fora do contexto da coleta de dados e da interação com o grupo técnico do laboratório.

Portanto, em fragmentos de diário de bordo buscaremos utilizar, de forma não usual, o texto em primeira pessoa, fazendo referência a uma percepção do pesquisador em relação ao que foi observado e não uma análise baseada em dados obtidos ao longo do processo. Espera-se, assim, que essa leitura possibilite um olhar mais abrangente sobre o problema pesquisado.

A entrada no laboratório de eletrônica do Departamento de Física Nuclear se deu no período de Março de 2007 a Junho de 2008, quando foi desenvolvido o protótipo do terminal de aceleração e, em paralelo, breves estágios com 
especialistas (técnicos, engenheiros e pesquisadores) das diversas partes do acelerador Pelletron. Nessa fase da pesquisa não houve uma preocupação em compreender o fazer científico do laboratório, como nos estudos de Latour e Woolgar (1979), mas de introdução do pesquisador no mundo do cientista a fim de promover um aprofundamento acerca dos conteúdos e técnicas envolvidas no experimento.

Esse fator é importante de ser ressaltado, pois os trabalhos da sociologia da ciência evocam duas dimensões metodológicas: a observação e o estranhamento; que pressupõe a neutralidade do pesquisador com o grupo e o distanciamento com o conhecimento ali produzido (SILVA, 2002). Caso diferente do apresentado nesse trabalho, onde o pesquisador participou de algumas produções científicas junto aos sujeitos pesquisados, culminando na participação de congressos da área estudada e que tinha como finalidade, essa imersão no laboratório, o aprofundamento do conhecimento técnico e científico sobre o objeto.

Portanto, o relato que se segue é uma tentativa de apresentar algumas dimensões da ciência do acelerador Pelletron, em particular dos técnicos, e articular essa forma de produzir conhecimento com aquilo que nos propusemos a criar através das estratégias de divulgação e, ao mesmo tempo, iluminar nossas reflexões sobre as dificuldades e limitações desse material. Assim, segue abaixo uma breve exposição sobre essas experiências:

"A entrada no laboratório Pelletron foi feita logo após os primeiros contatos com o co-orientador do projeto, quando fui incumbida de trabalhar no protótipo do acelerador. Para isso, fui apresentada ao engenheiro responsável pelo laboratório de eletrotécnica e aos técnicos, que fazem parte do grupo de reparo, manutenção e aprimoramento técnico da máquina. O engenheiro responsável é um funcionário muito antigo do departamento e que possui um conhecimento muito refinado sobre o Pelletron. Todos os problemas técnicos sobre o acelerador são, inicialmente, dirigidos a ele. Os técnicos que trabalham nesse grupo são profissionais também bastantes experientes. A interação com esses funcionários foi muito boa e todos os 6 técnicos se propuseram a ajudar no projeto, nos períodos de trabalho menos intenso, devido à minha falta de experiência. 
A idealização do protótipo, feita pelo engenheiro, foi discutida comigo em diversas pequenas reuniões aonde ele ia explicitando os desenhos técnicos. Fiquei encarregada de construir e introduzir os elementos para aprimorar o acelerador com a ajuda dos técnicos. Esse trabalho foi, em um primeiro momento, de difícil progresso pois foi necessário a construção de peças de tamanhos menores pelos mecânicos, que tinham prioridades em outras tarefas. Como eu era uma aluna novata no meio, o engenheiro teve que se interpor para conseguir que alguns pedidos fossem feitos de forma mais breve.

No período de trabalho, dois dos técnicos se tornaram também amigos mais próximos, devido à proximidade de idade, me dando maiores apoio para situações que envolviam um conhecimento técnico que eu não tinha. Assim, a construção da protótipo foi sendo desenvolvida ao passo que os problemas relacionados a ele aumentaram.

Sem dinheiro, o projeto teve que seguir fazendo adaptações enquanto $o$ grupo diminuiu sua participação devido à falta de apoio financeiro. Nesse período, preparamos um trabalho para apresentar em um congresso da área e os dois técnicos ajudaram na construção do painel e na análise de dados. Nesse período de coleta de dados, o pequeno grupo (eu e os dois técnicos) ficava até 1 h ou $2 \mathrm{~h}$ da madrugada para conseguir dados passíveis de serem apresentados no congresso. Foram feitos diversos gráficos de tensão versus corrente, que não condiziam com o esperado pelo grupo.

Para localizarmos um tempo para discutirmos esses problemas, visto que esses técnicos não trabalhavam no protótipo, ou seja, ele era um instrumento a mais a ser analisado no dia-a-dia deles, propusemos um café da tarde, onde cada um trazia bolo, pão e café; para discutirmos os problemas relacionados ao protótipo. Essa forma de burlar um tempo para focarmos no protótipo não obteve sucesso, apesar de mantermos os lanches como prática comum entre o grupo. O problema foi solucionado, depois de algum tempo, e o trabalho foi bem aceito pela comunidade.

Nesse período de trabalho, foi observado que a interação entre os técnicos e os cientistas possui dois extremos. No geral, apesar de bem tratados pelos grupos de pesquisa, que tem o interesse de que seus pedidos sejam atendidos com 
prioridade, alguns desses pesquisadores conseguem observar a importância desses profissionais como co-participantes na construção da ciência. São, em sua maioria, docentes que trabalham com processos de desenvolvimento de aparato experimental ou de estudos mais voltados ao contexto de aplicabilidade.

Outro fator interessante, é que esses profissionais têm maior facilidade de observar os erros técnicos relacionados ao aparato do acelerador. Também produzem material para aprimorar o maquinário e resolver problemas com baixo custo, geralmente, fazendo adaptações de peças antigas ou restauradas.

Todo esse processo do conhecimento técnico desses profissionais é fundamental para o desenvolvimento da ciência produzida no laboratório. São esses sujeitos que fazem com que o aparato experimental esteja em funcionamento para que haja as colisões esperadas e sejam corrigidos problemas.

O que se espera dessas reflexões é que sejam inseridos dentro das visitas, momentos capazes de promover diálogos ou situações; em que o público possa compreender o papel desses técnicos no fazer científico. Apesar de alguns desses profissionais já participarem de algumas apresentações com alunos de ensino médio, não existe espaço para um debate mais objetivo sobre esse tema. Uma possível forma de introduzir tais questões é trazer indicativos do papel desses sujeitos nos materiais como site, apresentações multimídias e principalmente, abrir espaços de diálogo com o público em visitas ao Pelletron. 


\title{
Capítulo 7
}

\section{Analisando as ações para compreender o todo}

\author{
¿rão se pode ectucar sem ao \\ mesmo tempo ensinar; uma educaça \\ sem aprendizagem é vazia e \\ portanto, degenera, com muita facilidade, \\ em retórica moral e emocional \\ otanna Arendt
}

A análise apresentada nesse capítulo refere-se às perspectivas mais amplas proporcionadas pelos dados, onde se propõe compreender como as articulações entre os saberes educacionais discutidos nos capítulos anteriores aparecem na interlocução dos diversos atores envolvidos. Assim, se em um primeiro momento, procuramos olhar para os dados de forma individual, agora, ampliaremos tal dimensão para discutirmos as relações estabelecidas entre o que se almeja do ponto de vista teórico e o que efetivamente aparece nas visitas.

Para essa segunda fase da análise dos dados foram desenvolvidas duas etapas. Inicialmente propusemos uma diferenciação em relação aos grupos de informações disponíveis para serem analisados e depois focamos nas categorias em si, que foram utilizadas para iluminar as reflexões acerca dos dados. Para tanto, apresentaremos nesse primeiro momento um breve relato das escolhas dos grupos e, em seguida, uma exposição das categorias.

O primeiro recorte consistiu em identificar os diferentes protagonistas, estabelecendo uma organização, de cunho estrutural, com a finalidade de procurar identificar percepções, discursos, debates, que provêm de grupos diversos, em relação aos mesmos assuntos. Ainda que possam ser analisados por categorias iguais, trazem consigo uma natureza de resposta díspar em relação ao público que a responde. O segundo recorte da análise refere-se aos aspectos a serem contemplados na análise propriamente dita. Nesse caso, devido à distinção da natureza dos dados, optamos por manter as três dimensões já sinalizadas, sendo que em cada dimensão foram identificadas diversas categorias de análise. Essas categorias foram, portanto, agrupadas em: material apresentado, percepção do 
público e cientistas e técnicos. Uma descrição detalhada dessas categorias é apresentada em seguida. As dimensões utilizadas, como já mencionado, foram o conhecimento científico, a perspectiva social no laboratório e o laboratório na sociedade. O conjunto desses dois recortes, quando considerados como um todo, determina uma matriz de análise que permite combinar grupos protagonistas e dimensões contempladas.

Quanto aos protagonistas da análise, o primeiro deles refere-se ao material apresentado, onde é agrupada a análise do site do laboratório, a apresentação multimídia, o protótipo do terminal do acelerador e a visita com professores da escola básica. Todos esses materiais têm como perspectiva comum a tentativa dos sujeitos do laboratório de construírem um diálogo com o público e, portanto, trazem consigo a concepção dos idealizadores acerca do que deveria ou poderia ser apresentado ao visitante, em especial, aos estudantes da escola básica.

O segundo protagonista da análise se refere à percepção do público em relação a sua visita ao laboratório Pelletron. Nesse conjunto de dados está inserido o material produzido pelos professores, o grupo focal com professores da escola pública e os questionários dos alunos-visitantes. Eles trazem como unidade, em relação à natureza dos dados, a especificidade de possuir um olhar como visitante do laboratório. Pressupõem-se, em termos gerais, que se relacionam com as dimensões que foram mais significativas para esses pesquisados em relação ao que foi apresentado no acelerador.

O terceiro protagonista se refere aos cientistas e técnicos, e incluem as entrevistas com os pesquisadores e a entrada no laboratório. Esses dois materiais se constituem como representantes de indivíduos que produzem a ciência e trazem as perspectivas sobre o trabalho científico no acelerador. Possuem uma dimensão particularizada do sentido das pesquisas e dos processos envolvidos nesse saber produzido no laboratório. Esse olhar condiz com a intenção desses sujeitos sobre o que eles gostariam que fosse apresentado ao público.

As dimensões de análise foram utilizadas como grade para a identificação e sistematização dos aspectos a serem contemplados, resultando em categorias de análise, que foram construídas através da reflexão pautada nas discussões que se 
seguiram até o momento. Tais categorias, como no grupo de dados apresentados, também estão contidas em um tema maior que as abarca. Essa perspectiva possibilita um olhar mais amplo sobre o assunto discutido e ao mesmo tempo, aprofunda essas dimensões quando se olha para as categorias que os representam. Esse tópico também pode facilitar a análise dos dados, possibilitando que fossem feitas regressões para os mesmos, conforme abrangêssemos a discussão, sem a necessidade de indicar pontos ou categorias específicas quando não fosse necessário no debate.

A primeira dimensão de análise se remete ao conhecimento científico onde se busca o sentido do saber que está envolvido no laboratório. A primeira categoria desse grupo é a do conhecimento físico que direciona o olhar para os conteúdos que estão associados ao acelerador. Eles aparecem tanto em relação ao que é produzido como conhecimento teórico até o saber necessário para compreender os conteúdos evolvidos no processo de acelerar o feixe.

A segunda categoria se refere ao funcionamento do acelerador e abarca todos os processos técnicos para que o Pelletron funcione. É caracterizado pela dimensão que envolve os processos de controle, ionização do feixe, produção de vácuo, etc.; que representam o conhecimento específico desse tipo de máquina. Também envolve os elementos de construção do acelerador e os tamanhos nele envolvidos.

A terceira categoria, objetivos/finalidades do acelerador, é caracterizada pela representação das intencionalidades da construção do aparato tecnológico e dos estudos desenvolvidos a partir dos dados que a máquina produz. Procura nesse contexto olhar as para as condições técnicas necessárias que visam promover a colisão dos átomos e no caso dos trabalhos desenvolvidos, tenta compreender que tipo de conhecimento se quer produzir com os dados dessa colisão.

A segunda dimensão é a perspectiva social dentro do laboratório que procura trazer uma visão sobre as relações estabelecidas no acelerador e na comunidade científica. Ela é caracterizada pelo olhar da construção da ciência mais amplo, buscando vislumbrar situações e momentos que fazem parte do fazer científico e 
que não aparecem de maneira explícita no produto final dos cientistas (artigos, palestras, entrevista).

A primeira categoria desse grupo é a inserção/reconhecimento na comunidade científica e busca olhar para a importância do laboratório no âmbito da comunidade de pesquisadores. Apresenta o papel do prestígio a ser almejado pelos cientistas ao desenvolverem seus trabalhos e como essas dimensões estão presentes no fazer da ciência dentro do acelerador.

A próxima categoria se remete a vida social no laboratório e é caracterizada pelas relações entre os sujeitos que trabalham e estudam nesse espaço. Procura olhar para as hierarquias estabelecidas e o papel de cada profissional nesse contexto. Também abarcar os espaços de trabalho com as divisões entre pesquisadores, funcionários administrativos e técnicos.

A terceira categoria, a produção/visão de ciência se remete à concepção dos sujeitos sobre a produção da ciência. Ela se refere aos processos de produção do conhecimento, as construções teóricas e experimentais, as inferências dos dados; procurando, em algumas situações, estabelecer uma relação entre a descoberta e a criatividade. Essa categoria se distingue das outras, pois traz em si uma dimensão implícita nos dados, refletindo uma característica sobre o trabalho científico que não é verbalizado diretamente pelos pesquisados.

Relação tecnologia e ciência é a quarta categoria e finaliza esse tema. Possui como finalidade vislumbrar as relações intrínsecas entre a construção do conhecimento científico e a dependência tecnológica nesses tipos de laboratórios. Tenta trazer à tona como essa relação se constitui no acelerador através da máquina e sua função de promover os experimentos que, futuramente, se transformarão em conhecimento construído da ciência.

A terceira dimensão é o laboratório na sociedade e procura olhar para a inserção do acelerador no contexto social, econômico e político em que ele participa. Sua função é reconhecer como o laboratório dialoga com a sociedade a sua volta, propondo interfaces com outras instituições, procurando participar de debates em 
outras instâncias além da acadêmica e buscando promover uma melhoria, em qualquer âmbito, para a comunidade ao seu entorno.

A primeira categoria desse tema é a aplicação/produtos/benefícios para sociedade, que pode ser entendida como os resultados dos trabalhos desenvolvidos no acelerador, de certo modo, se transformaram em produtos para a sociedade. Essa categoria busca olhar para os trabalhos que nascem com uma perspectiva aplicada ou os estudos se mostram passiveis de gerat produtos em benefício da sociedade. Não procuram aqui entrar na discussão entre os sentidos atribuídos ao que é básico e aplicado na pesquisa, mas aos instrumentos de utilidade social.

$\mathrm{Na}$ categoria seguinte, recorte acerca da instituição, se procura observar a história da instituição e sua inserção no contexto da universidade; trazendo um olhar sobre onde ela se insere nesse ambiente, qual sua função como laboratório de pesquisa e a relação que se estabelece entre o laboratório e os visitantes.

A categoria inserção social do laboratório se refere a questões éticas que são estabelecidas pelas comissões, os órgãos de controle que fiscalizam as pesquisas, agências responsáveis pelo financiamento dos trabalhos e as responsabilidades atribuídas aos grupos de pesquisa. Essa categoria olha para as questões sociais que estão imersas no ambiente do laboratório e que possuem a função de controlar os estudos através das diretrizes que provêm das demandas política, social e econômica nos laboratórios.

A categoria relações sociais do laboratório remete a suas diferentes formas de promover a divulgação científica e trabalhos em interface com outras instituições sociais. Procura olhar para a tentativa de inserção do Pelletron no mundo que o cerca e como se dão essas relações com outros sujeitos. Essa categoria remete a dimensões mais amplas do saber científico, pois evoca o papel da inserção social como parte do reconhecimento da ciência na sociedade.

Deste modo, foi construída uma matriz de análise que continha na primeira coluna o material que foi utilizado como estratégia para coleta de dados, separada por temas. Na coluna seguinte trouxemos o tema conhecimento científico em que foram inseridas as categorias referentes a esse contexto. O mesmo foi feito para os 
dois temas seguintes: perspectiva social dentro do laboratório e o laboratório na sociedade.

Os espaços ou células apresentadas na matriz foram preenchidas com 0 material proveniente da análise realizada no capítulo anterior ( $O$ que é apresentado e o que é compreendido), trazendo trechos que pudessem ser ilustrativos em relação aos dados analisados e à categoria especificada.

Essa imersão nas análises possibilitou que fossem introduzidos novos recortes sobre esse material, conduzindo a outras perspectivas de reflexão sobre cada um dos temas e, consequentemente, provendo uma interatividade entre o que foi produzido ao longo de toda a pesquisa. Com isso, a análise possibilitou redimensionar o olhar para algumas situações obscurecidas no contexto da coleta. Essa percepção aparece, por exemplo, quando são colocadas dimensões sobre a aprendizagem no laboratório, que se remetem, em determinados momentos, a uma compreensão mais ampla sobre essa aquisição pelos estudantes.

Abaixo, a matriz é ilustrada para melhor compreensão das discussões de sua construção. Para a apresentação da análise das categorias, onde são discutidas as percepções provindas dos dados obtidos, se optou por trazê-las em seções, sendo abordados de forma a respeitar as singularidades relacionadas à natureza dos dados. Para tanto, faremos nas seções seguintes algumas inferências acerca do que foi observado, estando disponível na parte dos anexos a matriz de análise preenchida que corresponde ao contexto das reflexões apresentadas (Anexo II) a partir dessas categorias. 


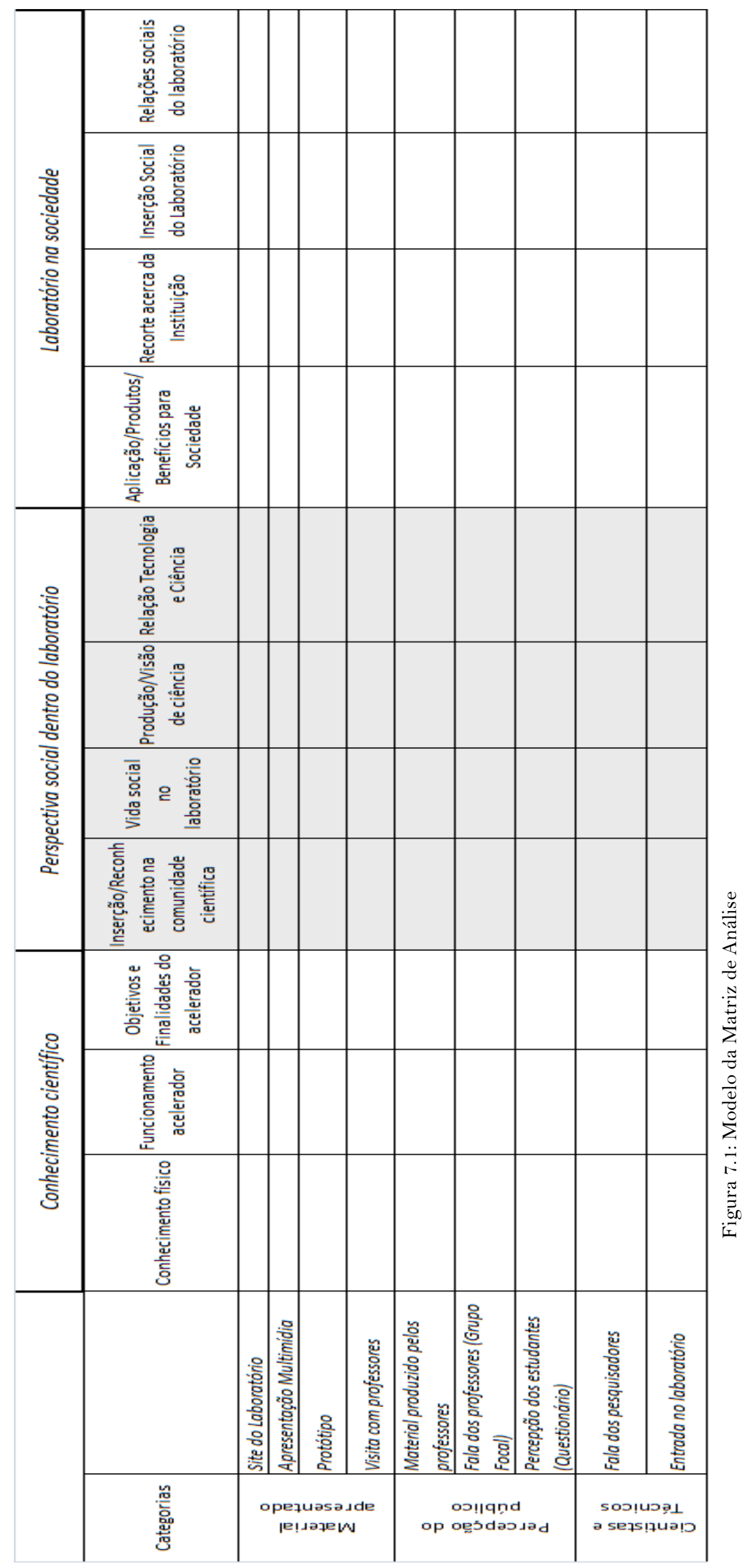




\subsection{Conhecimento Científico}

De modo geral, é possível observar que o conhecimento científico aparece de diferentes formas para os interlocutores envolvidos nesse trabalho. Em determinados momentos esse conhecimento busca referências no que se supõe seja o currículo escolar, enfatizando conteúdos físicos já discutidos nesses âmbitos. Em outros momentos, tal conhecimento é compreendido de maneira mais abrangente, que se refere ao olhar para o todo sob a perspectiva do aparato e como o saber se relaciona a esse contexto.

Abaixo apresentamos a matriz de análise do conhecimento científico preenchida de forma simplificada, trazendo os temas gerais que a representam.

\begin{tabular}{|c|c|c|c|c|}
\hline \multirow[b]{2}{*}{ Categorias } & & \multicolumn{3}{|c|}{ Conhecimento científico } \\
\hline & & Conhecimento físico & Funcionamento acelerador & $\begin{array}{c}\text { Objetivos/Finalidades do } \\
\text { acelerador }\end{array}$ \\
\hline \multirow{4}{*}{ 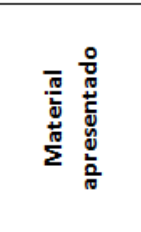 } & Site do Laboratório & $\begin{array}{c}\text { Conteúdos de física clássica e } \\
\text { moderna }\end{array}$ & $\begin{array}{l}\text { Finalidade dos elementos que } \\
\text { constituem o acelerador }\end{array}$ & Estudos fundamentais e práticos \\
\hline & Apresentação Multimídia & $\begin{array}{c}\text { Conteúdos de fisica clássica e } \\
\text { moderna }\end{array}$ & Processos de colisão do feixe e alvo & Conhecimento sobre a natureza \\
\hline & Protótipo & Conteúdos de física clássica & Construção simplificada do terminal & Acelerar feixe \\
\hline & Visita com professores & $\begin{array}{c}\text { Conteúdos de física clássica e } \\
\text { moderna }\end{array}$ & $\begin{array}{c}\text { Conhecimento técnico de aceleração } \\
\text { do feixe }\end{array}$ & Sentido de acelerar \\
\hline Categorias & & Conhecimento físico & Funcionamento acelerador & $\begin{array}{c}\text { Objetivos/Finalidades do } \\
\text { acelerador }\end{array}$ \\
\hline \multirow{3}{*}{ 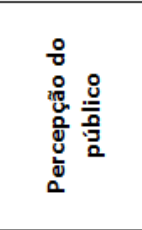 } & $\begin{array}{l}\text { Material produzido pelos } \\
\text { professores }\end{array}$ & $\begin{array}{l}\text { Conteúdos de física clássica e } \\
\text { moderna }\end{array}$ & Processos de controle do feixe & $\begin{array}{c}\text { Descobrir particulas e produzir } \\
\text { tecnologias }\end{array}$ \\
\hline & $\begin{array}{l}\text { Fala dos professores (Grupo } \\
\text { Focal) }\end{array}$ & $\begin{array}{c}\text { Tipos de conhecimentos } \\
\text { preparatórios para conhecer o } \\
\text { acelerador }\end{array}$ & $\begin{array}{l}\text { Elementos tecnicos envolvidos na } \\
\text { aceleração }\end{array}$ & \\
\hline & $\begin{array}{l}\text { Percepção dos estudantes } \\
\text { (Questionário) }\end{array}$ & & Aparato tecnológico de controle & \\
\hline Categorias & & Conhecimento físico & Funcionamento acelerador & $\begin{array}{c}\text { Objetivos/Finalidades do } \\
\text { acelerador }\end{array}$ \\
\hline \multirow{2}{*}{ 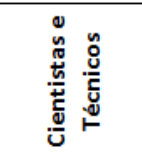 } & Fala dos pesquisadores & Conteúdos de fisica moderna & & Produzir novas equações \\
\hline & Entrada no laboratório & $\begin{array}{l}\text { Conhecimento aplicados da física } \\
\text { clássica }\end{array}$ & Processos de manutenção & \\
\hline
\end{tabular}

Figura 7.2: Matriz de Análise do Conhecimento Científico

\subsubsection{Conhecimento Físico}

Foi observada na análise do material produzido uma forte influência dos conteúdos físicos associados, em grande parte, aos conteúdos escolares. Tal dimensão aparece em relação: ao site, na apresentação e no protótipo; em geral, associados ao ensino médio, e na apresentação das visitas, associados aos conhecimentos da graduação. Esse reconhecimento dos temas abordados em sala de aula reflete uma tentativa de diálogo com a escola básica sob a dimensão do 
conhecimento. No entanto, é observado que a apresentação desse conhecimento, principalmente no site, possui uma visão pragmática acerca do conteúdo, trazendo temas e explicações diretas, sem a preocupação com a linguagem da ciência transpostas ao público leigo e a relação entre os conteúdos abordados. Ainda que de forma apenas implícita, parece haver uma suposição de que a simples apresentação dos conceitos e fenômenos será suficiente para o entendimento dos mesmos, por parte dos alunos e professores.

Em relação à percepção do público esse conhecimento aparece sob outra dimensão, a da apropriação do saber para a compreensão do que é apresentado na visita. Remete, na produção dos professores, aos conteúdos físicos abordados no currículo propriamente dito, mas também no grupo focal, na importância desse saber para favorecer o diálogo com os cientistas. Assim como no caso da produção dos materiais, aparecem temas da física clássica (eletromagnetismo, termodinâmica) e da física moderna (física nuclear e de partículas). Outra situação que nos parece relevante é a ausência da aquisição dos conteúdos na fala dos estudantes, que pode refletir uma percepção diferente acerca do sentido das visitas.

Em relação aos dados referentes aos cientistas e técnicos aparece uma preocupação dos pesquisadores em discutir aspectos conceituais sobre os modelos científicos, procurando aprofundar tal conhecimento. No caso dos técnicos, esse conhecimento físico aparece como elemento integrador entre a física e sua inserção na manutenção da máquina.

\subsubsection{Funcionamento do acelerador}

$\mathrm{Na}$ apresentação multimídia e na fala do pesquisador, durante aa visita, o funcionamento do acelerador aparece como meio para atingir a finalidade do experimento. Ele representa, nesse contexto, uma forma de questionar os elementos necessários para chegar ao objetivo de colidir núcleos atômicos. No caso do protótipo, essa categoria apresenta uma dimensão mais direta, de explicar o aparato tecnológico em maior detalhe, através das fontes, fios, roldanas; que constituem esse sistema. No site, essa apresentação aparece nos andares a serem visitados e sua funcionalidade em relação ao todo. 
Na percepção do público, a categoria é representada pela compreensão dos professores sobre os elementos que constituem a máquina e as situações técnicas que envolvem o processo de acelerar o feixe. Nesse sentido, parece que não existe, entre os professores, uma necessidade de discutir a finalidade do conjunto nesse momento, mas há uma prioridade em focalizar alguns aspectos particulares do aparato técnico que envolve o Pelletron. No entanto, esse conhecimento direcionado ao técnico não se refere ao conteúdo, mas às dimensões nele envolvidas, sua maneira de interligar com outros instrumentos, etc. $\mathrm{Na}$ fala dos alunos, aparece o tema a sala de comando, como uma representação do funcionamento, não diretamente, mas das formas de se controlar o sistema técnico.

No grupo de cientistas e técnicos, o tema surge na constituição do trabalho dos responsáveis pela manutenção do acelerador. $\mathrm{Na}$ fala dos pesquisadores, não aparece o tema sobre o funcionamento propriamente dito do acelerador, dando indícios de uma concepção mais teórica que esses cientistas possuem sobre o tema.

\subsubsection{Objetivos/Finalidades do acelerador}

No material apresentado as finalidades do acelerador aparecem de formas distintas. Enquanto o site e a apresentação multimídia procuram olhar para os objetivos a partir das pesquisas desenvolvidas no laboratório, o protótipo apresenta o tema de forma mais direta sob a perspectiva da montagem para a colisão dos núcleos. No âmbito da visita, aparecem essas questões na demanda dos visitantes, sob a dimensão do sentido dos experimentos ou aquilo que se procura no contexto dos dados.

Em relação ao público, o tema aparece apenas na produção dos professores que procuram olhar para a finalidade das pesquisas relacionado-as a descoberta de novas partículas e na produção de tecnologias. O tema não aparece no grupo focal e na fala dos estudantes.

Para os pesquisadores, esse tema está direcionado para a produção da ciência, pois enfatiza os processos de pesquisa com a finalidade de produzir equações ou novos conhecimentos. No caso dos técnicos, os objetivos não 
aparecem devido à natureza do trabalho técnico que pode evocar olhares mais direcionados na resolução dos problemas.

\subsection{Perspectiva social dentro do laboratório}

O olhar para a perspectiva social trouxe indícios das diferentes concepções acerca do reconhecimento da ciência na sociedade. Esse aspecto aparece de forma mais explicita na fala do público e de maneira implícita nos cientistas. Em relação à vida social no laboratório, o interesse parte apenas dos estudantes, quando trazem um interesse pelo local de trabalho e estudo do pesquisador.

A visão de ciência é múltipla nesses dados, que representam as muitas concepções acerca do fazer científico. Foi observado que a relação entre ciência e tecnologia se mostra difícil de ser introduzida na prática dos docentes pesquisados, refletindo a própria formação dos professores e os currículos estabelecidos na escola básica. Abaixo segue a matriz de análise simplificada.

\begin{tabular}{|c|c|c|c|c|c|}
\hline \multirow[b]{2}{*}{ Categorias } & & \multicolumn{4}{|c|}{ Perspectiva social dentro do laboratório } \\
\hline & & $\begin{array}{l}\text { Inserção/Reconhecimento } \\
\text { na comunidade científica }\end{array}$ & $\begin{array}{l}\text { Vida social no } \\
\text { laboratório }\end{array}$ & $\begin{array}{l}\text { Produção/Visão de } \\
\text { ciência }\end{array}$ & $\begin{array}{c}\text { Relação Tecnologia e } \\
\text { Ciência }\end{array}$ \\
\hline \multirow{4}{*}{ 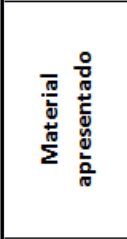 } & Site do Laboratório & $\begin{array}{c}\text { Importância do laboratório para a } \\
\text { comunidade científica }\end{array}$ & & $\begin{array}{c}\text { Desvendar os mistérios da } \\
\text { natureza }\end{array}$ & \\
\hline & $\begin{array}{l}\text { Apresentação } \\
\text { Multimídia } \\
\end{array}$ & & & $\begin{array}{c}\text { Curiosidade cientifica através } \\
\text { de perguntas }\end{array}$ & $\begin{array}{c}\begin{array}{c}\text { Equipamentos que fornecem } \\
\text { energia }\end{array} \\
\end{array}$ \\
\hline & Protótipo & & & & \\
\hline & Visita com professores & & $\begin{array}{c}\text { Relações entre os diversos } \\
\text { sujeitos que trabalham no } \\
\text { laboratório }\end{array}$ & Fazer hipóteses e testá-las & $\begin{array}{c}\text { Processos de vedação para } \\
\text { promover vácuo }\end{array}$ \\
\hline Categorias & & $\begin{array}{l}\text { Inserção/Reconhecimento } \\
\text { na comunidade científica }\end{array}$ & $\begin{array}{l}\text { Vida social no } \\
\text { laboratório }\end{array}$ & $\begin{array}{l}\text { Produção/Visão de } \\
\text { ciência }\end{array}$ & $\begin{array}{c}\text { Relação Tecnologia e } \\
\text { Ciência }\end{array}$ \\
\hline \multirow{3}{*}{ 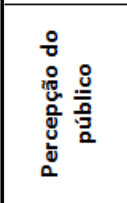 } & \begin{tabular}{|l|} 
Material produzido pelos \\
professores
\end{tabular} & O papel da pesquisa nacional & & $\begin{array}{c}\text { Experimentação e os interesses } \\
\text { politicos }\end{array}$ & \\
\hline & $\begin{array}{l}\text { Fala dos professores } \\
\text { (Grupo Focal) }\end{array}$ & O papel da pesquisa nacional & & $\begin{array}{c}\text { Olhar para o trabalho do } \\
\text { pesquisador }\end{array}$ & $\begin{array}{c}\text { Tamanho da máquina, seus } \\
\text { elementos }\end{array}$ \\
\hline & \begin{tabular}{|l} 
Percepção dos \\
estudantes
\end{tabular} & & $\begin{array}{c}\text { Como espaço de trabalho } \\
\text { e estudo }\end{array}$ & & \\
\hline Categorias & & $\begin{array}{l}\text { Inserção/Reconhecimento } \\
\text { na comunidade científica }\end{array}$ & $\begin{array}{l}\text { Vida social no } \\
\text { laboratório }\end{array}$ & $\begin{array}{l}\text { Produção/Visão de } \\
\text { ciência }\end{array}$ & $\begin{array}{c}\text { Relação Tecnologia e } \\
\text { Ciência }\end{array}$ \\
\hline \multirow{2}{*}{ 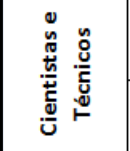 } & Fala dos pesquisadores & $\begin{array}{c}\text { A singularidade do laboratório } \\
\text { Pelletron }\end{array}$ & & $\begin{array}{l}\text { Construção do conhecimento } \\
\text { pela experimentação }\end{array}$ & \\
\hline & Entrada no laboratório & & $\begin{array}{c}\text { Relações entre técnicose } \\
\text { cientistas }\end{array}$ & $\begin{array}{l}\text { Papel dos técnicos na } \\
\text { produção da ciência }\end{array}$ & $\begin{array}{l}\text { Aparato técnico na } \\
\text { construção dos dados }\end{array}$ \\
\hline
\end{tabular}

Figura 7.3: Matriz de Análise da Perspectiva Social no Laboratório

\subsubsection{Inserção/Reconhecimento na comunidade científica}

No material apresentado, podemos observar que o reconhecimento do laboratório aparece apenas no site, onde se afirma a importância do Pelletron em 
relação a sua pesquisa, no entanto, sem especificar o contexto da afirmação. Contudo, pode-se inferir que nesse caso se remete à relevância do acelerador na comunidade científica. Em relação às outras estratégias analisadas, não aparece a discussão sobre o assunto, dando indícios de que o tema pode ser considerado desagregador na tentativa do dialogo laboratório e público.

Em relação ao público, esse tema aparece na fala dos professores e não na fala dos alunos; geralmente ele é apresentado de maneira ufanista, reverenciando o papel dos pesquisadores nacionais e buscando nivelar a qualidade desses profissionais em relação aos pesquisadores estrangeiros. É interessante perceber que esse tipo de posição não é defendido pelos cientistas, que procuram demonstrar, quando abordam o tema, que ainda existe espaço para pesquisa nos aceleradores como o nosso, mas sem procurar comparar ou representar suas pesquisas no âmbito da nacionalidade, ou seja, a ciência é demonstrada como neutra.

\subsubsection{Vida social no laboratório}

A categoria referente às relações sociais no laboratório aparece na fala dos cientistas durante as visitas, quando esses se referem a situações de convívio entre os sujeitos que trabalham no acelerador. Nas respostas dos estudantes, está presente quando reconhecem o espaço do laboratório como local de trabalho e estudo. $E$ nas relações entre funcionários e pesquisadores, é mencionada no contexto da descrição do Pelletron. Essa categoria se mostrou bastante interessante, pois aponta uma relevante ausência do tema nos dados analisados.

\subsubsection{Produção/Visão da ciência}

A produção/visão da ciência aparece no site e na apresentação multimídia, através da apresenação do acelerador como instrumento para produzir dados e a, partir dos mesmos, decodificar características da natureza. Quando o cientista apresenta sua concepção de produção da ciência, ele remete à construção de hipóteses; o experimento busca refutar ou legitimar a hipótese levantada, a fim de que ela seja passível de ser colocada à prova para outras situações. A ausência de asepctos dessa natureza no protótipo dá indícios de que o aparato experimental não 
possui a dimensão da produção da ciência, pois traz a perspectiva tecnológica do acelerador e não o saber teórico.

Quando olhamos para o conjunto de dados referente à percepção do público, mais uma vez, o tema retoma na fala dos professores e é ausente na dos alunos. Para os docentes, a produção da ciência é discutida em diversas instâncias, seja na discussão da natureza da ciência de forma mais ampla, seja na inserção de debates acerca das diferenças sobre a prática e a teoria. Comparece, também, quando são mencionados interesses políticos e econômicos que conduzem algumas pesquisas ou sobre como se dá a experimentação, (fazendo analogias com os choques mecânicos dos experimentos das bolinhas).

No grupo dos cientistas e técnicos, essa questão aparece na discussão acerca da pesquisa básica e aplicada, trazendo, implicitamente, uma reflexão sobre as insuficiências das suas definições. Está também presente quando se aborda a natureza da "descoberta" no fazer científico ao trazer o debate sobre os diferentes resultados que se obtêm no contexto da produção dos dados, possibilitando novos saberes acerca de um determinado problema. Em relação aos técnicos, discute-se a dimensão do conhecimento específico desses profissionais na construção do saber provindo do laboratório.

\subsubsection{Relação tecnologia e ciência}

No material apresentado a discussão sobre as relações tecnologia e ciência aparece em dois momentos: na apresentação multimídia, quando é discutido o papel do aparato experimental para o aumento da velocidade dos feixes e na fala do cientista, quando são mencionados os elementos técnicos necessários para garantia do bom andamento do experimento. A ausência do assunto na discussão do protótipo reitera que, nesse caso, predomina uma ênfase no conhecimento do funcionamento e não no sentido do aparato tecnológico em si. $\mathrm{Na}$ fala dos professores, essa dimensão sobre a tecnologia envolvida no fazer científico aparece nas falas do grupo focal, quando os docentes comentam sobre o aparato experimental e seu processo de aceleração. É interessante perceber que, nas propostas didáticas dos docentes, era esperado que tal dimensão aparecesse, pois o curso ministrado trazia uma discussão sobre CTS. No entanto, ela é ausente em 
todas as produções desses professores e pode indicar dificuldades de inserir tal tema na prática docente; seja pela complexidade ou seja pelas limitações de tempo dos cursos.

No caso dos cientistas e técnicos, o tema aparece somente na prática dos especialistas para a manutenção do laboratório, permitindo ampliar a concepção de atuação desses profissionais na construção do conhecimento. A ausência na fala dos cientistas remete a uma preocupação voltada para o saber teórico que está envolvido nas pesquisas.

\subsection{Laboratório na sociedade}

A inserção do laboratório como instituição no conjunto mais amplo da sociedade e suas tentativas de promover a interação com o público aparecem de forma ainda tímida em relação aos dados. Ela comparece, de certa forma, nas aplicações dos estudos em outras pesquisas, enfatizando um caráter de aprimoramento do conhecimento. De maneira geral, a dimensão do laboratório enquanto instituição inserida na sociedade ainda é pouco percebida nas tentativas de discutir a aproximação das atividades do laboratório com o público. Estão praticamente ausentes as questões voltadas à importância do Pelletron em relação a História da ciência ou da universidade, e também sem uma reflexão acerca de suas formas de interação com o mundo que o cerca.

Se o tema é praticamente ignorado pelos pesquisadores em suas falas e no material, surpreende a visão dos professores, que dão espaços para tais discussões em sua prática, mas pouco é lembrado quando procuram olhar para as visitas e suas interações com a escola.

Esse tema foi o menos lembrado por qualquer dos grupos estudados, podendo ser considerado, em geral, pouco atraente para as discussões propostas. Pode-se compreender essa ausência como a dificuldade de abordar essa dimensão do laboratório que reflete, talvez, a inexistência também dessas questões na formação dos pesquisados. Ao mesmo tempo, pode também ser interpretado como a não percepção dos problemas de financiamento da ciência em uma escala mais 
ampla,ou à dificuldade de problematização desses recursos em relação às outras demandas sociais.

Abaixo apresentamos a matriz de análise com alguns temas sucintos que foram retirados dos dados apresentados na matriz completa (Anexo III).

\begin{tabular}{|c|c|c|c|c|c|}
\hline \multirow[b]{2}{*}{ Categorias } & & \multicolumn{4}{|c|}{ Laboratório na sociedade } \\
\hline & & $\begin{array}{c}\text { Aplicação/Produtos/ } \\
\text { Benefícios para }\end{array}$ & $\begin{array}{l}\text { Recorte acerca da } \\
\text { Instituição }\end{array}$ & $\begin{array}{l}\text { Inserção Social do } \\
\text { Laboratório }\end{array}$ & $\begin{array}{c}\text { Relações sociais do } \\
\text { laboratório }\end{array}$ \\
\hline \multirow{4}{*}{ 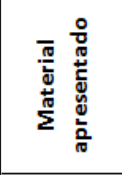 } & Site do Laboratório & $\begin{array}{c}\text { Técnicas da fisica nuclear } \\
\text { na arqueologia e medicina }\end{array}$ & Laboratório na Instituição & & $\begin{array}{c}\text { Mostras as pesquisas do } \\
\text { laboratório }\end{array}$ \\
\hline & Apresentação Multimídia & Estudos interdisciplinares & Laboratório na Instituição & & \\
\hline & Protótipo & & & & \\
\hline & Visita com professores & & $\begin{array}{c}\text { Contexto da implementação } \\
\text { do acelerador }\end{array}$ & & \\
\hline Categorias & & $\begin{array}{c}\text { Aplicação/Produtos/ } \\
\text { Benefícios para } \\
\text { Sociedade }\end{array}$ & \begin{tabular}{|c|} 
Recorte acerca da \\
Instituiç̧ão (Histórica, \\
na Universidade)
\end{tabular} & $\begin{array}{l}\text { Inserção Social do } \\
\text { Laboratório }\end{array}$ & $\begin{array}{l}\text { Relações sociais do } \\
\text { laboratório }\end{array}$ \\
\hline \multirow{3}{*}{ 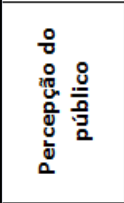 } & $\begin{array}{l}\text { Material produzido pelos } \\
\text { professores }\end{array}$ & $\begin{array}{l}\text { Aplicabilidades para a } \\
\text { sociedade }\end{array}$ & $\begin{array}{c}\text { Questões históricas sobre o } \\
\text { Pelletron }\end{array}$ & $\begin{array}{c}\text { Investimentos nos } \\
\text { aceleradores de particulas }\end{array}$ & $\begin{array}{c}\text { Diálogo entre alunos e o } \\
\text { laboratório }\end{array}$ \\
\hline & \begin{tabular}{|l} 
Fala dos professores (Grupo \\
Focal)
\end{tabular} & & $\begin{array}{c}\text { História e Implementação do } \\
\text { acerlador Pelletron }\end{array}$ & & Intercâmbio escola - universidade \\
\hline & $\begin{array}{l}\text { Percepção dos estudantes } \\
\text { (Questionário) }\end{array}$ & & & & \\
\hline Categorias & & $\begin{array}{c}\text { Aplicação/Produtos/ } \\
\text { Benefícios para } \\
\text { Sociedade }\end{array}$ & $\begin{array}{c}\text { Recorte acerca da } \\
\text { Instituição (Histórica, } \\
\text { na Universidade) }\end{array}$ & $\begin{array}{l}\text { Inserção Social do } \\
\text { Laboratório }\end{array}$ & $\begin{array}{l}\text { Relações sociais do } \\
\text { laboratório }\end{array}$ \\
\hline \multirow{2}{*}{ 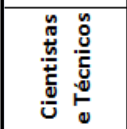 } & Fala dos pesquisadores & $\begin{array}{l}\text { Estudos aplicaveis na } \\
\text { medicina, industria, etc. }\end{array}$ & & & \\
\hline & Entrada no laboratório & & & & \\
\hline
\end{tabular}

Figura 7.4: Matriz de Análise do Laboratório na Sociedade

\subsubsection{Aplicação/Produtos/Benefícios para a sociedade}

No material apresentado as aplicações aparecem em dois momentos: no site e na apresentação multimídia; no primeiro são apresentados os estudos interdisciplinares no laboratório e as aplicabilidades em outras áreas da pesquisa; em relação à apresentação multimídia aparece uma lista de funcionalidades dos estudos do laboratório, enfatizando as questões de cooperação com outras áreas do saber. Percebe-se que ao mostrar ao público as aplicações dos estudos, estes são focados nas diferentes formas que os conhecimentos produzidos e trabalhados no acelerador podem servir para aprimorar e ampliar o conhecimento em outras áreas, dando pouca ênfase às aplicações no cotidiano da sociedade. Tal dimensão mais prática desse conhecimento talvez seja deixada de lado devido às diversas instâncias tecnológicas que perpassam esse conhecimento até o produto final e que, por conseguinte, pode ser descaracterizado como saber produzido no laboratório. 
Em relação ao público, a preocupação com os produtos aparece somente nas propostas de aula dos professores, quando são abordados benefícios e malefícios da energia nuclear, as produções tecnológicas provindas dos estudos no acelerador, a medicina nuclear, etc. A ausência na fala do grupo focal e dos alunos podem caracterizar o próprio desconhecimento do público sobre o caráter prático desse conhecimento, podendo ser reconhecido como um reflexo da educação tradicional pautada na concepção do conhecimento per se.

$\mathrm{Na}$ fala dos cientistas esse tema aparece de forma mais voltada para as questões sociais, refletindo uma preocupação desses profissionais em enfatizar a inserção desses estudos mais diretamente no cotidiano dos visitantes. Enfoca as aplicações mais gerais, como no caso do material apresentado, mas também remete a situações vivenciadas no dia-a-dia.

\subsubsection{Recorte acerca da instituição}

Olhar para a instituição como parte de um complexo acadêmico maior aparece no site e na apresentação multimídia quando se busca demonstrar como o instituto está associado a departamento e à instituição. No entanto, na fala do pesquisador, na visita, essa dimensão se amplia quando é comentado o contexto da instalação do acelerador no governo militar, suas necessidades particulares de financiamento em relação a outros departamentos do instituto, etc.

A preocupação em saber onde se situa esse laboratório também aparece na fala dos professores e nas propostas deles, quando procuram introduzir temas a serem abordados com os alunos como a história do Pelletron, sua instalação e as dinâmicas de interação com outras instituições. Os alunos, assim como os pesquisadores, não compartilham essa preocupação a priori, o que pode ser talvez decorrente, nesse caso, da especificidade das questões apresentadas aos pesquisados.

\subsubsection{Inserção social do laboratório}

Essa categoria, que buscou olhar para a influência da sociedade no laboratório, apareceu somente nas propostas dos professores, situando o tema nos 
grandes valores que são investidos em aceleradores como o LHC e quais os interesses políticos, econômicos e sociais; para que o dinheiro público fosse designado para esses laboratórios.

A ausência dessa discussão nos dados pode ser compreendida como diferentes formas de encarar o problema pelos pesquisadores, que aparecem no discurso cotidiano deles, mas pode ser considerada como tema implícito na intenção de abrir as portas do laboratório e, portanto, não sendo necessário que seja apresentado ao público.

\subsubsection{Relações sociais do laboratório}

O site que é apresentado ao público mostra a tentativa de interação com a sociedade enfatizando o interesse na apresentação das pesquisas do acelerador para os visitantes. Sem caracterizar de forma explícita o tipo de diálogo que se quer promover, o site busca apenas contextualizar como se dá tal demonstração.

Para o público esse interesse se dá na fala dos professores, quando propõem um diálogo com o laboratório em atividade da escrita de cartas dos alunos para os pesquisadores sobre as impressões da visita, as concepções dos estudantes acerca da física nuclear e das pesquisas que são desenvolvidas pelos cientistas. No grupo focal também inserem questões voltadas às políticas públicas quando enfatizam a necessidade de interação universidade - escola para a formação continuada dos professores.

\subsection{Os saberes da mediação}

As formas de mediação também foram analisadas no material apresentado, onde procuramos enfatizar os saberes que aparecem na fala dos cientistas, nas visitas ao laboratório e no material apresentado. Para olhar alguns desses indícios nos dados, optamos por dividi-los em três grupos, conforme sugerido por Fauche (2008), que são os: da mediação direta, que inclui a interação entre o cientista e os professores visitantes; da mediação indireta, onde são apresentados o site, apresentação multimídia e o protótipo; e a mediação de gestão, que inclui a fala dos cientistas e a entrada no laboratório. É interessante observar que, de certa forma, há 
uma correspondência, ainda que limitada, entre as formas de mediação a serem priorizadas e as dimensões de análise utilizadas.

A partir dessa primeira divisão, inserimos na matriz de análise dos saberes vinculados à mediação, segundo propõe Queiróz et. at. (2002), que se caracterizam pelos saberes compartilhados com a escola, da escola com a educação em ciências e os saberes dos museus. Assim, propomo-nos a inserir como "categorias" os saberes específicos relacionados a cada uma dessas perspectivas.

Abaixo apresentamos a matriz, com os espaços em branco, onde foram inseridas as falas e trechos representativos dos materiais analisados (Anexo III). Essa matriz possibilitou com que se pudesse compreender em quais dimensões aparecem os saberes de mediação nas tentativas de diálogo entre cientistas e público.

Optou-se por retirar as percepções do público dessa análise, pois apesar de compreender que ela poderia trazer alguns indícios sobre aquilo que é compreendido, trata-se de um aspecto de segunda ordem nessa análise da mediação. Ela reflete outra dimensão de análise, que não faz parte das reflexões dos autores quando propõem os saberes de mediação, associados àqueles que promovem a divulgação e não aos que a recebem.

Em função dessa perspectiva teórica, as categorias que ajudam a iluminar a reflexão sobre a mediação, apesar de se encaixarem em uma posição educacional voltada aos museus de ciências, e reconhecendo os laboratórios científicos como distintos desses espaços, olhamos para esses saberes de forma a traduzir alguns aspectos necessários para se promover a educação em espaços não formais, e que tal olhar reflete uma perspectiva de aprimorar o diálogo também nos laboratório científicos. 


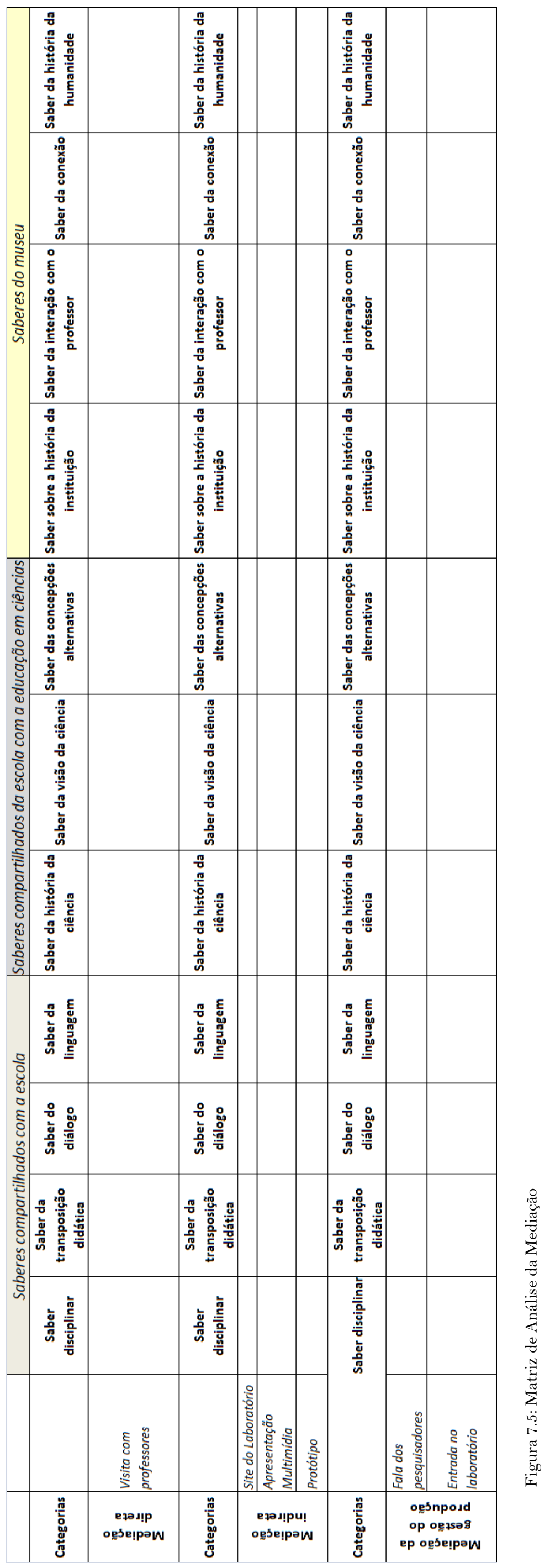


$\mathrm{Na}$ matriz acerca dos saberes compartilhados com a escola aparecem, de certo modo, diversos elementos que constituem os conhecimentos necessários para a apresentação aos visitantes e alguns indícios de saberes da transposição didática, que envolvem, de forma simplificada, uma preocupação na didatização dos processosvinculados às questões técnicas e à pesquisa do laboratório.

O saber do diálogo também aparece como no material analisado, visto que se apresenta em ao menos uma vez nas perspectivas. O saber da linguagem, no entanto, associado a formas de se demonstrar e discutir aspectos acerca do laboratório para que o público consiga compreender esse discurso, aparece com mais freqüência; na apresentação multimídia, em diversas abordagens que são utilizadas para explicar determinados assuntos e na fala dos pesquisadores, quando propõem a inserção de exemplos no diálogo com os estudantes.

\begin{tabular}{|c|c|c|c|c|c|}
\hline \multirow[b]{2}{*}{ Categorias } & & \multicolumn{4}{|c|}{ Saberes compartilhados com a escola } \\
\hline & & $\begin{array}{c}\text { Saber } \\
\text { disciplinar }\end{array}$ & $\begin{array}{c}\text { Saber da } \\
\text { transposição } \\
\text { didática }\end{array}$ & $\begin{array}{l}\text { Saber do } \\
\text { diálogo }\end{array}$ & $\begin{array}{l}\text { Saber da } \\
\text { linguagem }\end{array}$ \\
\hline 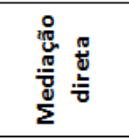 & $\begin{array}{l}\text { Visita com } \\
\text { professores }\end{array}$ & \begin{tabular}{|c|} 
Apresentado de \\
forma \\
aprofundadada \\
pelo pesquisador
\end{tabular} & \begin{tabular}{|c|} 
Reformulação da \\
explicação dos \\
processos na fala \\
do cientista \\
\end{tabular} & $\begin{array}{c}\text { Aparece na } \\
\text { interação com } \\
\text { visitantes }\end{array}$ & \\
\hline Categorias & & $\begin{array}{c}\text { Saber } \\
\text { disciplinar }\end{array}$ & $\begin{array}{c}\text { Saber da } \\
\text { transposição } \\
\text { didática }\end{array}$ & $\begin{array}{l}\text { Saber do } \\
\text { diálogo }\end{array}$ & $\begin{array}{l}\text { Saber da } \\
\text { linguagem }\end{array}$ \\
\hline \multirow{3}{*}{ 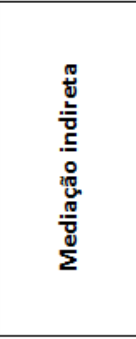 } & Site do Laboratório & $\begin{array}{l}\text { Aparece nos } \\
\text { conteúdos } \\
\text { abordados }\end{array}$ & & $\begin{array}{l}\text { Intenção do } \\
\text { diálogo com a } \\
\text { comunidade } \\
\text { escolar } \\
\end{array}$ & \\
\hline & $\begin{array}{l}\text { Apresentação } \\
\text { Multimídia }\end{array}$ & $\begin{array}{l}\text { Aparece nos } \\
\text { conteúdos } \\
\text { abordados }\end{array}$ & $\begin{array}{c}\text { Apresentam os } \\
\text { conteúdos de } \\
\text { forma didatizada }\end{array}$ & & $\begin{array}{l}\text { Múltiplas } \\
\text { abordagens }\end{array}$ \\
\hline & Protótipo & $\begin{array}{l}\text { Aparece nos } \\
\text { conteúdos } \\
\text { abordados }\end{array}$ & $\begin{array}{l}\text { Simplificação do } \\
\text { aparato }\end{array}$ & & \\
\hline Categorias & & $\begin{array}{c}\text { Saber } \\
\text { disciplinar }\end{array}$ & $\begin{array}{c}\text { Saber da } \\
\text { transposição } \\
\text { didática }\end{array}$ & $\begin{array}{l}\text { Saber do } \\
\text { diálogo }\end{array}$ & $\begin{array}{l}\text { Saber da } \\
\text { linguagem }\end{array}$ \\
\hline \multirow{2}{*}{ 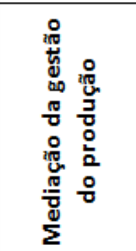 } & $\begin{array}{l}\text { Fala dos } \\
\text { pesquisadores }\end{array}$ & $\begin{array}{l}\text { Saber disciplinar } \\
\text { de outras áreas }\end{array}$ & & \begin{tabular}{|c|} 
Informaçôes \\
para promover \\
o diálogo com \\
estudantes \\
\end{tabular} & $\begin{array}{c}\text { Construção de } \\
\text { exemplos } \\
\text { concretos }\end{array}$ \\
\hline & $\begin{array}{l}\text { Entrada no } \\
\text { Iaboratório }\end{array}$ & $\begin{array}{c}\text { O conhecimento } \\
\text { da fisica no saber } \\
\text { técnico }\end{array}$ & & & \\
\hline
\end{tabular}

Figura 7.6: Matriz Simplificada sobre Saberes Compartilhados na Escola

É interessante perceber que apesar dos saberes disciplinares, de transposição e do diálogo aparecerem na fala dos pesquisados e na concepção do material, ele é quase ausente no saber de linguagem, o que pode refletir uma 
consciência da necessidade de uma interação didática com o público, mas apresenta certa dificuldade associada a como utilizar recursos para fazer essa interação. Em relação à linguagem, foi observado que na maioria dos dados, apesar de surgirem indícios de mudanças nas explicações para transformá-las em situações mais didáticas, ao mesmo empo, essas explicações acabam recaindo ainda em uma linguagem específica da ciência do laboratório.

Em relação aos saberes compartilhados pela escola com a educação em ciências, é observado, na fala dos cientistas, uma preocupação acerca das concepções alternativas relacionadas ao modelo atômico, refletindo, em grande parte, a preocupação em não pautar o em muita simplificação.

\begin{tabular}{|c|c|c|c|c|}
\hline \multirow[b]{2}{*}{ Categorias } & & \multicolumn{3}{|c|}{$\begin{array}{l}\text { Saberes compartilhados da escola com a educação } \\
\text { em ciências }\end{array}$} \\
\hline & & $\begin{array}{l}\text { Saber da história da } \\
\text { ciência }\end{array}$ & $\begin{array}{l}\text { Saber da visão da } \\
\text { ciência }\end{array}$ & $\begin{array}{c}\text { Saber das } \\
\text { concepções } \\
\text { alternativas }\end{array}$ \\
\hline 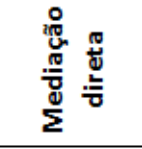 & $\begin{array}{l}\text { Visita com } \\
\text { professores }\end{array}$ & & & \\
\hline Categorias & & $\begin{array}{l}\text { Saber da história da } \\
\text { ciência }\end{array}$ & $\begin{array}{l}\text { Saber da visão da } \\
\text { ciência }\end{array}$ & $\begin{array}{c}\text { Saber das } \\
\text { concepções } \\
\text { alternativas }\end{array}$ \\
\hline \multirow{3}{*}{ 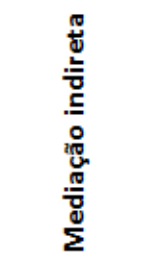 } & Site do Laboratório & & & \\
\hline & $\begin{array}{l}\text { Apresentação } \\
\text { Multimídia }\end{array}$ & & & \\
\hline & Protótipo & & & \\
\hline Categorias & & $\begin{array}{l}\text { Saber da história da } \\
\text { ciência }\end{array}$ & $\begin{array}{l}\text { Saber da visão da } \\
\text { ciência }\end{array}$ & $\begin{array}{c}\text { Saber das } \\
\text { concepções } \\
\text { alternativas }\end{array}$ \\
\hline \multirow{2}{*}{ 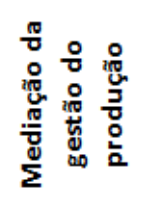 } & $\begin{array}{l}\text { Fala dos } \\
\text { pesquisadores }\end{array}$ & & & $\begin{array}{l}\text { Desmistificação do } \\
\text { modelo atômico }\end{array}$ \\
\hline & $\begin{array}{l}\text { Entrada no } \\
\text { laboratório }\end{array}$ & & & \\
\hline
\end{tabular}

Figura 7.7: Matriz Simplificada sobre Saberes Compartilhados da Escola com a Educação

A ausência do tema referente aos saberes da escola em relação aos conteúdos apresentados pode ser compreendida como uma dificuldade de reconhecer o papel da educação no laboratório de pesquisa. Esse distanciamento 
do conhecimento do ensino de ciências é, de certo modo, resultado dos sentidos atribuídos ao que se quer apresentar sobre o laboratório, ou seja, o enfoque nos conteúdos científicos escolares.

Em relação aos saberes do museu, que reconhecemos aqui como o saber associado ao laboratório, é pouco reconhecido o saber sobre a história da instituição ou da história dos personagens que construíram a máquina,, como os cientistas e os técnicos, responsáveis pela instalação do acelerador.

No saber da conexão, observamos que esse tema aparece em relação ao aparato tecnológico, quando o pesquisador direciona as discussões para o papel de cada elemento em ligação ao que já foi visto e, também, no protótipo quando é utilizada uma escala menor para representar a máquina

De modo geral, os saberes de interação com o professor não aparecem de forma explícita nos dados analisados. Isso poderia estar presente nas interações entre os cientistas e visitantes, mas, , nesse caso, trata-se de um público mais amplo do que professores em contexto escolar, já que relacionado com o ato de trazer seus alunos para conhecer o acelerador (fora da escola). Portanto, essa dimensão fica obscurecida nos dados, sendo de difícil acesso com a coleta na forma em que foi realizada.

Em relação ao conhecimento sobre a humanidade, esse tema é ignorado devido ao olhar objetivo das visitas, que focam no laboratório e na sua constituição atual, direcionando as atividades para a apresentação do que é produzido hoje. Esse saber estabelecido na humanidade e o sentido da construção dessas máquinas para o desenvolvimento da sociedade são deixados de lado em favor de um olhar mais direto sobre os conteúdos, pesquisas e aparato técnico que fazem parte da construção da história do Pelletron e pouco de sua relação com o mundo. De certo modo, reitera, também, o que foi observado em relação aos dados sobre o laboratório inserido na sociedade. 


\begin{tabular}{|c|c|c|c|c|c|}
\hline & & \multicolumn{4}{|c|}{ Saberes do museu } \\
\hline Categorias & & $\begin{array}{c}\text { Saber sobre a } \\
\text { história da } \\
\text { instituição }\end{array}$ & $\begin{array}{c}\text { Saber da } \\
\text { interação com o } \\
\text { professor }\end{array}$ & Saber da conexão & $\begin{array}{l}\text { Saber da história } \\
\text { da humanidade }\end{array}$ \\
\hline 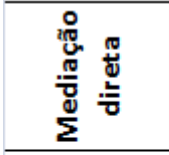 & $\begin{array}{l}\text { Visita com } \\
\text { professores }\end{array}$ & $\begin{array}{l}\text { Apresentado } \\
\text { na figura do } \\
\text { cientista }\end{array}$ & & $\begin{array}{c}\text { Relaçôes que o } \\
\text { cientista estabelece } \\
\text { durante a visita }\end{array}$ & \\
\hline Categorias & & $\begin{array}{c}\text { Saber sobre a } \\
\text { história da } \\
\text { instituição }\end{array}$ & $\begin{array}{c}\text { Saber da } \\
\text { interação com o } \\
\text { professor }\end{array}$ & Saber da conexão & $\begin{array}{l}\text { Saber da história } \\
\text { da humanidade }\end{array}$ \\
\hline \multirow{3}{*}{ 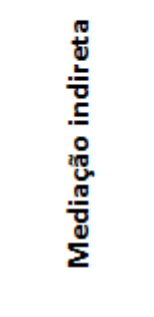 } & $\begin{array}{l}\text { Site do } \\
\text { Laboratório }\end{array}$ & & & & \\
\hline & $\begin{array}{l}\text { Apresentação } \\
\text { Multimídia } \\
\end{array}$ & & & & \\
\hline & Protótipo & & & $\begin{array}{c}\text { Aparato técnico ao } \\
\text { acelerador }\end{array}$ & \\
\hline Categorias & & $\begin{array}{l}\text { Saber sobre a } \\
\text { história da } \\
\text { instituição }\end{array}$ & $\begin{array}{c}\text { Saber da } \\
\text { interação com o } \\
\text { professor }\end{array}$ & Saber da conexão & $\begin{array}{l}\text { Saber da história } \\
\text { da humanidade }\end{array}$ \\
\hline \multirow{2}{*}{ 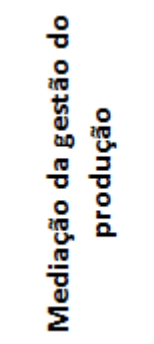 } & $\begin{array}{l}\text { Fala dos } \\
\text { pesquisadores }\end{array}$ & & & & \\
\hline & $\begin{array}{l}\text { Entrada no } \\
\text { laboratório }\end{array}$ & $\begin{array}{c}\text { Técnicos } \\
\text { responsáveis } \\
\text { pela instalação } \\
\text { do acelerador }\end{array}$ & & & \\
\hline
\end{tabular}

Figura 7.8: Matriz Simplificada sobre Saberes do Museu

Em uma perspectiva de conjunto, podemos perceber que a análise dos saberes de mediação evidencia as dificuldades encontradas pelos pesquisados e pelo material em efetivar suas intenções de divulgação. Essa dimensão é percebida pelas intencionalidades dos gestores e a ausência de determinados saberes como o da linguagem no material apresentado. Mesmo que essa perspectiva busque apenas demonstrar ausências em relação ao que é necessário para promover uma educação científica em espaços não formais, reflete no nosso caso, a uma reflexão 
sobre as necessidades de gerar uma interação entre os cientistas e público, mas também compreender uma limitação nas estratégias propostas.

Isso aparece de maneira geral quando se observa uma visão orientada em relação aos saberes compartilhados na escola, que pode ser fruto de uma tradição conteudista que ela carrega para o laboratório, visto que os cientistas também fizeram parte dessa escola; mas que indica um conhecimento sobre os saberes necessários para interação com os estudantes.

Contudo, quando se busca olhar para o papel do ensino de ciências compartilhado com a escola, percebe-se uma ausência de interlocução entre os conhecimentos da pesquisa em educação, provavelmente associada mais ao desconhecimento do que a uma postura de distanciamento. Isso evidencia, mais uma vez, a importância da interlocução com os pesquisadores em ensino de ciências na construção das visitas nesses espaços..

\subsection{Síntese dos dados}

De modo geral, podemos observar a partir dos dados, algumas dimensões que envolvem as interações no laboratório e que perpassam diversas perspectivas de atuação desses espaços. Nesse sentido, apresentamos a seguir alguns tópicos de síntese dessa análise, para pontuar os elementos mais significativos dessa discussão:

- Ênfase nos conteúdos de Física, pelos cientistas, associados às pesquisas desenvolvidas no Pelletron, preocupados com uma dimensão mais didática e, de certa forma, buscando complementar o conhecimento escolar dos alunos. Seria algo como a adoção de um modelo de déficit: superar, nas visitas, as carências do ensino escolar, sem atentar muito para os limites de aprendizado que esse espaço utilizado pode, de fato, promover.

- Ênfase nos conteúdos de Física, associados ao funcionamento do acelerador pelos professores e cientistas. Por parte dos pesquisadores, compreendendo os detalhes de tal funcionamento quase que como pré-requisitos para a compreensão do aparato como um todo, 
essencial para dar sentido à visita. Por parte dos professores, identificando alguns aspectos em que se estabelecem pontes ou relações com conhecimentos por eles já adquiridos, dando sentido local a alguns conhecimentos físicos.

- Destaque para a dimensão teórica da ciência pelos cientistas e no material apresentado. Ou seja, ainda que se trate de um laboratório onde predomina 0 desenvolvimento da ciência em termos experimentais, pouca atenção é dada ao caráter de conhecimentos dessa natureza, suas características e seus vínculos com o tratamento teórico, reforçando um modelo de produção da ciência essencialmente teórico.

- Proposta de diálogo entre o conteúdo curricular e os saberes científicos do acelerador (funcionamento, pesquisas) na fala dos professores, reconhecendo, no entanto, as dificuldades (ou limitações) que os alunos do ensino médio teriam para isso.

- Ausência de discussões sobre a inserção social do laboratório e nas tentativas de interlocução com outras instituições. Assim, a menos de suas relações com o departamento e a universidade, a ausência de considerações de natureza mais ampla, de forma implícita, reforçam um certo alheamento das questões sociais, passando a imagem quase que de um espaço à parte, com poucas ligações com questões políticas e econômicas que permeiam o restante das relações sociais.

- Presença, na fala dos estudantes, de aquisição de saberes sobre a instituição e a universidade; sinalizam seu interesse em reconhecer o cientista em seu ambiente de trabalho, a dinâmica desse ambiente e seu dia-a-dia. Dado o prestígio social atribuído a essa profissão, o contato com esses ambiente tem um papel importante para os alunos.

- Reconhecimento do trabalho dos cientistas como parte da ampliação do conhecimento sobre a ciência no país, na fala dos professores; ou seja, o trabalho dos cientistas e suas possíveis contribuições na produção da ciência, além da contribuição à ciência no Brasil, seriam reconhecidos como elementos de formação para uma educação científica, podendo, também, aproximar jovens das carreiras científicas. 
- Relação entre ciência e tecnologia, na construção do conhecimento científico nas propostas de aulas dos professores. Reconhecimento da presença do saber técnico na construção da ciência. Em relação tanto aos aspectos dos conhecimentos técnicos, como às relações de dependência entre o conhecimento científico e os aspectos tecnológicos indispensáveis ao desenvolvimento das atividades, essas relações são explicitamente pouco reconhecidas e valorizadas, mantendo uma valorização do conhecimento científico como superior.

Esses tópicos correspondem a alguns aspectos que podem iluminar as reflexões sobre as potencialidades de atuação para a promoção da educação científica no laboratório. Assim, foram percebidas três perspectivas que podem ser contempladas nas visitas ao acelerador: a do conhecimento físico, da vida no laboratório e a do laboratório na perspectiva social. Como buscamos ilustrar na figura abaixo, elas trazem em sua constituição diversos elementos que, de certo modo, aparecem nos dados, mas de forma aleatória e não sistematizada.

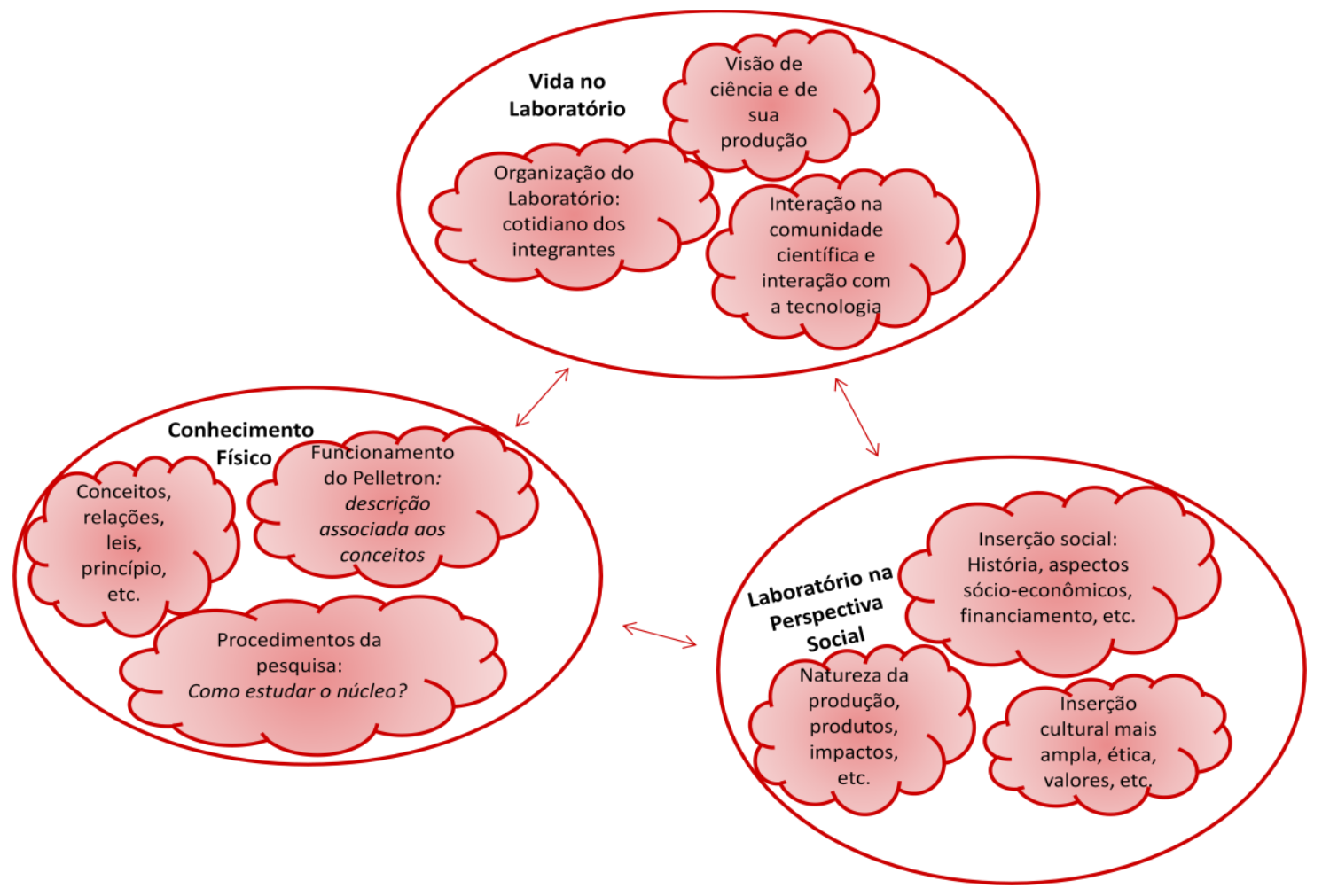

Figura 7.9: Atuação no Laboratório 
Como resultado da análise apresentada, as propostas de atuação nas visitas, por parte do laboratório, centraram sua atenção, sobretudo, no conhecimento físico, enquanto as demais dimensões foram pouco contempladas. Paralelamente, aos alunos, parece interessar mais de perto uma interação com a vida do laboratório, buscando construir novos significados sobre o ser cientista e, quem sabe, com potencial para desmistificar concepções muitas vezes predominantes na mídia. Finalmente, as dimensões que envolvem discussões sobre a contribuição das pesquisas ou perspectivas sociais mais amplas, que poderiam mobilizar valores éticos ou de posicionamento crítico, estão praticamente ausentes. Como já foi observado anteriormente, essa ausência implicitamente reforça o distanciamento da ciência dos outros fazeres sociais, ao mesmo tempo que reforça uma perspectiva de educação científica centrada apenas nos conceitos e relações físicas.

Apontar essas dimensões, para um trabalho dentro do laboratório, sinaliza diferentes perspectivas que podem ser trabalhadas, em parte ou em conjunto, promovendo uma compreensão muito mais ampla acerca do conhecimento científico e, também, que seja mais aprofundada no que se refere ao entendimento dos diversos saberes atrelados ao fazer da ciência. Esse quadro aponta possibilidades para se promover uma interlocução entre essas diferentes perspectivas, apoiando o conhecimento científico em outras instâncias de sua construção e que pode ser inserido nas visitas ao acelerador. 


\section{Capítulo 8}

\section{Considerações finais}

Sada na vida deve ser temido, somente compreendido. Agora é hora de compreender mais para temer menos.

Cranie Punie

O início desse projeto se constituiu da prática e das muitas tentativas de divulgação das atividades de um laboratório científico, o acelerador Pelletron, juntamente com docentes e técnicos da instituição. Essas atividades se transformaram, ao longo dos anos, abrindo espaço para diversas questões e motivando muitas indagações.

É nesse contexto que a reflexão sobre quais as possíveis formas de promover um diálogo entre os cientistas e alunos, professores ou público se transformou em objetivo desse trabalho. Buscamos encontrar caminhos que norteiem laboratórios de pesquisa científica na produção de visitas a esses espaços, com a perspectiva de promover uma educação científica.

Nesse processo, procuramos situar nossas questões e os ambientes de produção científica no âmbito das pesquisas em educação em ciências, no sentido de identificar os elementos, resultados e referências que pudessem contribuir para nossas reflexões. Recorremos a autores preocupados com os espaços de ensino não formal, localizando contribuições sobre a aprendizagem científica para além da sala de aula, a natureza das mediações envolvidas e a natureza do olhar para a ciência que esses espaços possibilitam.

Reconhecemos, no entanto, que os laboratórios, como centros de produção da ciência, têm algumas especificidades que não se identificam com aquelas usualmente presentes em museus ou exposições, o que thes permitiria atuar em perspectivas ímpares, a serem melhor delineadas e priorizadas, envolvendo suas contribuições como espaços de produção da ciência. Em relação a esse aspecto, algumas reflexões de autores da sociologia da ciência trouxeram elementos reveladores. 
Nesse sentido, aprofundamos as reflexões que vêm sendo desenvolvidas quanto à alfabetização científica e às contribuições de abordagens CTS no ensino. Essas discussões permitiram melhor situar a natureza do conhecimento científico a ser considerado nesses espaços, acrescentando outras e importantes dimensões educacionais aos conteúdos científicos usualmente reconhecidos no âmbito escolar.

As dimensões educacionais, expressas nas expectativas dos saberes a serem promovidos, sinalizaram indícios de quais aspectos poderiam ser privilegiados nas tentativas de aproximação com a escola e o público. Com esses indícios, promovemos uma análise de alguns materiais e resultados das atividades, que vinham sendo desenvolvidas pelo projeto de divulgação, ao longo dos anos anteriores.

No entanto, através do material apresentado e da análise dos dados, pudemos observar que ainda existem muitas lacunas acerca dessas dimensões educacionais que idealizávamos promover, nas visitas ao Pelletron. Essas lacunas, de certa forma, são parte das diferentes concepções e expectativas que estão envolvidas, por um lado, por aqueles que programam as visitas e, por outro lado, por aqueles que visitam o acelerador.

O conhecimento científico é, a nosso ver, aquele que apresenta uma maior discrepância em relação aos diferentes olhares dos grupos pesquisados. Ele reflete as muitas ideias sobre o que é conhecer ciência, seja do ponto de vista doa alunos ou dos professores, seja do ponto de vista dos cientistas do laboratório, e em que medida esses conhecimentos poderiam/deveriam estar mais ou menos vinculados aos conteúdos curriculares.

No entanto, o que queremos demonstrar, para além dessas diferenças, é que essa dimensão do conhecer ciência pode ser ampliada, através do diálogo com os pesquisadores do laboratório, ao se enfatizar outros aspectos do fazer científico que não os conceitos e aspectos da tecnologia usualmente abordados por esses profissionais. Assim, as propostas de divulgação não precisariam ser direcionadas apenas ao conhecimento produzido, pesquisado ou associado ao saber teórico, mas poderiam promover uma ampliação sobre o sentido de conhecer ciência, passando a incluir a natureza e as formas do fazer da ciência. 
Essa concepção de aprender sobre ciência, engajando os estudantes para o estudo da física, também é compartilhado com os docentes; pois caracteriza uma procura por dar sentido ao que é aprendido, sem descolar os conteúdos da escola à ciência apresentada nos laboratórios. Essa perspectiva não contradiz à ideia de abranger o conhecimento, mas evoca outro objetivo às visitas, pois remete a conhecer a ciência em seus aspectos de produção, possibilitando condições mais reais sobre esse "aprender ciência".

Assim, o sentido das visitas deve ser olhado como uma perspectiva de apropriação do conhecimento aprendido em sala de aula ou instigador dessa aprendizagem em outras instâncias da vida do sujeito. Refere-se a olhar o mundo de outra forma, de querer introduzir o vocabulário científico no contexto cotidiano, ter uma opinião sobre a ciência e compreender que, para isso, é necessário entender mais sobre ciência, ler mais sobre ciência, estudar mais sobre ciência e pensar mais sobre a ciência no espaço social.

Essa apropriação, no âmbito dos professores, pode ser localizada quando eles enfatizam que as visitas lhes permitem passar a saber mais e ganhar confiança para falar sobre o tema em sala de aula. Esse conhecimento sobre os aceleradores é, de certo modo, mais amplo, pois caracteriza outro tipo de conhecer implícito, que não condiz somente com a apreensão dos conteúdos científicos propriamente ditos. Remetem a um reconhecimento daquele mundo como parte do seu, pois evocam dimensões que são de seu entendimento sobre ensinar. Ou seja, ensinar não é encarado como falar sobre, mas ser representante de um grupo, um saber.

No caso dos alunos, as visitas refletem o que denominamos de apropriação de conhecimentos outros, que se apresentam quando esses estudantes indicam a universidade, a instituição ou as pessoas como momentos relevantes da visita. $\mathrm{O}$ sentido dela se reflete em ampliar outros saberes associados às relações sociais estabelecidas no ambiente do laboratório. Esse reconhecimento de apropriação desses saberes não pode ser desconsiderado, pois amplia a inserção dos alunos que não estão pré-dispostos às carreiras científicas a compreenderem mais sobre a ciência. 
Esse olhar também deve ser direcionado à apreensão dos conteúdos envolvidos na preparação dos alunos para as visitas, visto que as dificuldades encontradas por determinados estudantes em aprender sobre esses conhecimentos não pode vir a ser fonte de insucesso para conhecer o laboratório. As visitas devem ser pautadas em abranger e não excluir os alunos; devem olhar para outras dimensões sobre aprender ciência e possibilitar o diálogo com os especialistas em assuntos associados aos laboratórios científicos que não somente os conteúdos per se.

Essas discussões estão relacionadas diretamente às mediações estabelecidas nesses espaços, que envolvem os saberes dos interlocutores desse processo e, quando compartilhados na escola, apresentam uma forte ligação com os saberes disciplinares e do diálogo. Apesar de importante, olhar somente para a escola e ignorar o campo da educação é correr o risco de submeter os estudantes aos mesmos erros que, muitas vezes, caracterizam o contexto escolar.

A identificação dessa multiplicidade de olhares mostra que é importante procurar entender as visitas, todo o processo e todos os protagonistas em torno a ela de um ponto de vista social e educacional mais amplo. Nesse olhar, surgiram duas perspectivas diferentes, que podem traduzir, respectivamente, a situação vivenciada e a situação desejada.

A primeira perspectiva implica em entendermos as visitas, e todo o processo referente a elas, como uma pirâmide, onde o conhecimento científico é o ápice, o objeto primordial de interesse e o objetivo último das ações. Ou seja, como se todas as intenções e ações fossem mobilizadas pelo conhecimento científico. Assim, tudo que o envolve o trabalho dos cientistas, o laboratório e a sociedade são em suma, estruturas voltadas para um único objetivo, que é aprimorar o saber da ciência, produzir conhecimento científico. Essa perspectiva aparece tanto para alguns professores e para os cientistas, sendo o sentido de vir ao acelerador e aquilo que se deve priorizar ao apresentá-lo ao público.

Essa concepção, que é aquela predominante nos dados analisados, e é ilustrada no esquema da figura a seguir (Figura 8.1), pretende que o conhecimento determine o fazer e a construção da ciência, elegendo os cientistas como 
responsáveis por essa demanda. Nesse caso, esse fazer é diretamente atrelado ao saber teórico, deixando de lado ou implícito o papel da experimentação. Assim, a organização estrutural do espaço, dos fazeres e das pessoas não possui outra finalidade que dispor os saberes técnicos para garantir o funcionamento do laboratório para o aprimoramento da ciência, que é a grande meta humana.

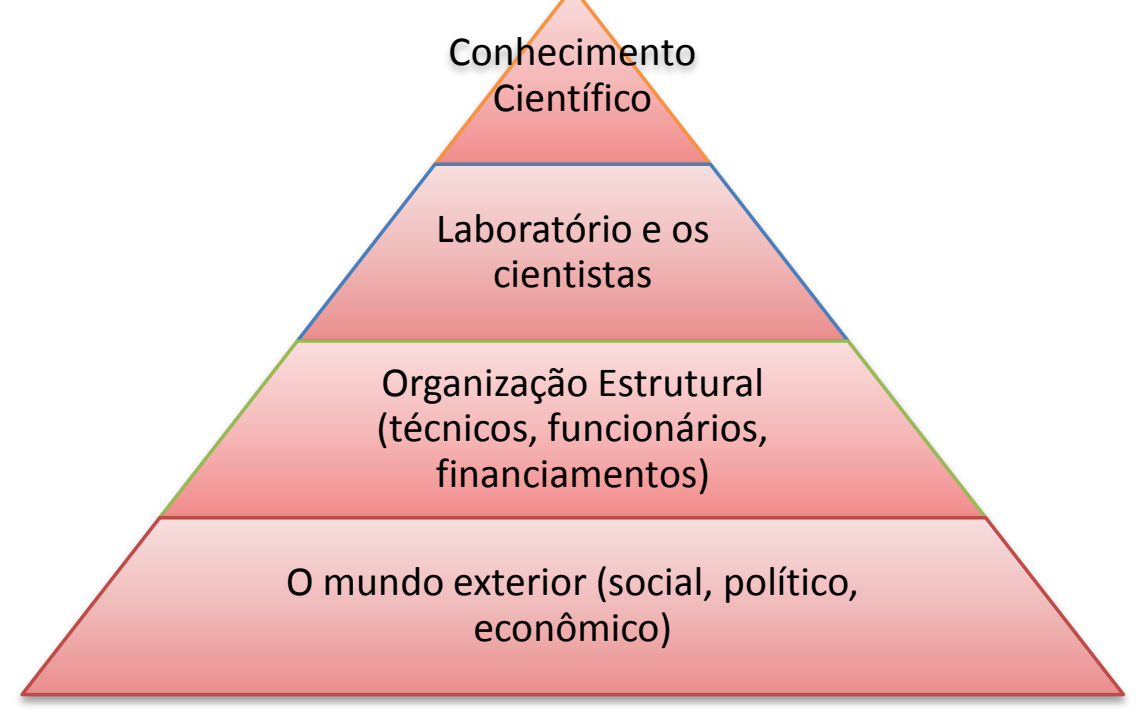

Figura 8.1: Perspectiva piramidal para a Estrutura das Visitas

Nessa perspectiva, e ainda que de forma implícita, a sociedade está distante da ciência, pois não conhece seus fazeres. O papel da sociedade é pouco interativo, descolada do fazer da ciência, como se ela, de maneira intangível, não sofresse as influências e nem fizesse parte das esferas econômicas e políticas sociais. Da mesma forma, apresenta seus cientistas como sujeitos não preocupados com a sociedade, desconectados dos problemas do mundo que os cerca, como sujeitos geniais, incomuns e especiais.

Em contraste com essa, a segunda perspectiva que emerge de nossa reflexão inverte essas relações. Nesse caso, trata-se de olhar para o laboratório de uma maneira mais ampla e nos remete a compreender o conhecimento gerado nesse espaço como um processo complexo do fazer científico, inserido nos espaços sociais da mesma forma que outros fazeres. Isso indica que reconhecer a ciência do laboratório nas visitas envolveria compreender as relações que se estabelecem entre os diversos sujeitos e contextos que envolvem essa construção, numa relação 
horizontal, reconhecendo sua especificidade, mas dentro de uma perspectiva de igualdade de valores.

O que propomos, na figura seguinte (Figura 8.2), é esquematizar essas relações, a partir de um conhecimento que é gerado sobre um mundo que não é diferente do que os visitantes vivem. Esse mundo possui diversos interesses aos quais todos estão submetidos e que, também, se reflete no laboratório. Tal contexto indica que o trabalho do cientista não é isolado, depende da cooperação e de outros conhecimentos, que juntos geram novos saberes.

Essa maneira de olhar para o que se apresenta aos visitantes requer novas formas de compreender a ciência do laboratório, sendo necessário introduzir outras instâncias desse fazer, para além dos conceitos, relações e fenômenos, tais como o papel do conhecimento técnico, as relações entre ciência e tecnologia, a inserção do contexto social, os financiamentos, interesses políticos, etc.

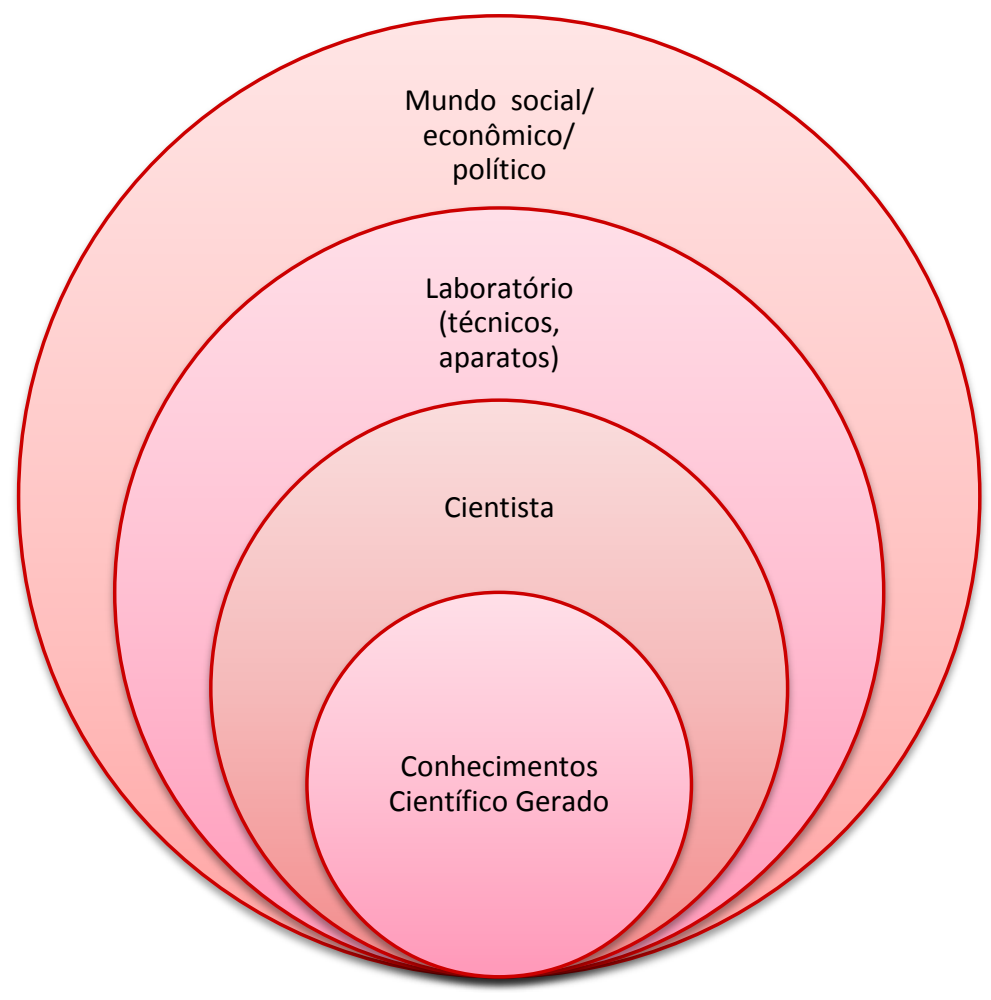

Figura 8.2: Perspectiva cultural ampla para a Estrutura das Visitas

Essa maneira de conceber as visitas de forma mais ampla é o que chamamos de percepção da cultura científica, que busca demonstrar aspectos do fazer da ciência que não se limitam ao conhecimento científico sem, no entanto, 
descaracterizar sua importância para o trabalho do cientista e do funcionamento do laboratório. O que se propõe é uma perspectiva que possa olhar as características que envolvem esse fazer da ciência de forma a promover uma educação científica mais abrangente, que envolva esses conteúdos contextualizados em seu processo de produção.

Essas perspectivas culturais devem ser compreendidas como uma forma de abranger questões que envolvam debates acerca dos valores da ciência, os financiamentos das pesquisas, as múltiplas formas de saber-fazer no laboratório, os sujeitos que participam dessa construção, as relações estabelecidas dentro do laboratório e entre a comunidade científica.

O conhecimento científico, nessa perspectiva, aparece como parte da compreensão desse debate, sendo contextualizado em uma dinâmica mais abrangente onde se podem reconhecer de maneira mais clara aspectos que estão implícitos no produto final das pesquisas. Esse fato, no entanto, não se refere somente à aprendizagem dos conteúdos, mas à possibilidade de introduzir outros debates que possam subsidiar a formação de sujeitos mais emancipados. Um reconhecimento de maneira menos ingênua acerca da produção da ciência pode possibilitar reflexões mais aprofundadas sobre o tema e, conseqüentemente, a elaboração de opiniões sobre prioridades, encargos, responsabilidades ou, até mesmo, autoridades relacionadas à ciência.

A questão que emerge desse debate é buscar entender quais seriam as dimensões de atuação das instituições envolvidas nesse processo. Cabe salientar que não deve recair sobre o laboratório a missão de promover o aprendizado de conceitos científicos básicos dos estudantes, mas de fortalecer e ampliar os conhecimentos adquiridos no contexto escolar, dando novas possibilidades de alargar as concepções dos alunos e a prática dos professores, para introduzir situações não vivenciadas na sala de aula.

Por outro lado, o desafio é identificar todas as questões potencialmente relevantes, não para tratar de todas elas, mas para poder fazer escolhas sobre elas. A proposta de visualizar essas muitas relações é apresentada de forma simplificada na Figura 8.3, a seguir. 


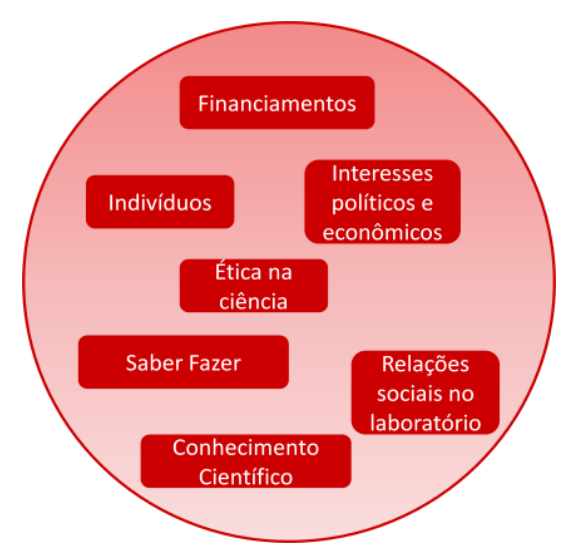

Figura 8.3: Aspectos da Cultura Científica

Cabe à escola preparar os sujeitos para o mundo: social, econômico e político, dando aos estudantes suporte para serem críticos diante das desigualdades sociais, nas decisões sobre estratégias econômicas dos grupos financeiros, nas decisões pautadas no discurso científico, etc. Esse ensinar o conteúdo e educar para a cidadania é intrínseco e envolve aprender para além das definições, procurando orientar os alunos para a transformação social e consciência ambiental de ação no mundo. Ainda que essa compreensão geral venha se generalizando, muito frequentemente o ensino de ciências é considerado à parte, distanciado dessas finalidades pela sua linguagem e especificidade. As visitas podem ser um espaço para reverter essa tendência, ao invés de reforçá-la.

A sociedade, em contrapartida, também se envolve no laboratório, com suas instituições de financiamento e órgãos de controle, que fazem o papel social de olhar, fiscalizar e criticar aquilo que não condiz com as regras estabelecidas pela comunidade, em comum acordo entre os diversos representantes desse universo. A sociedade faz sua parte também na escola, promovendo críticas quando ela não faz seu papel - mesmo que em muitos casos esse papel não esteja claro - e financiando a estrutura desse conglomerado de funcionários, prédios, materiais, etc. 


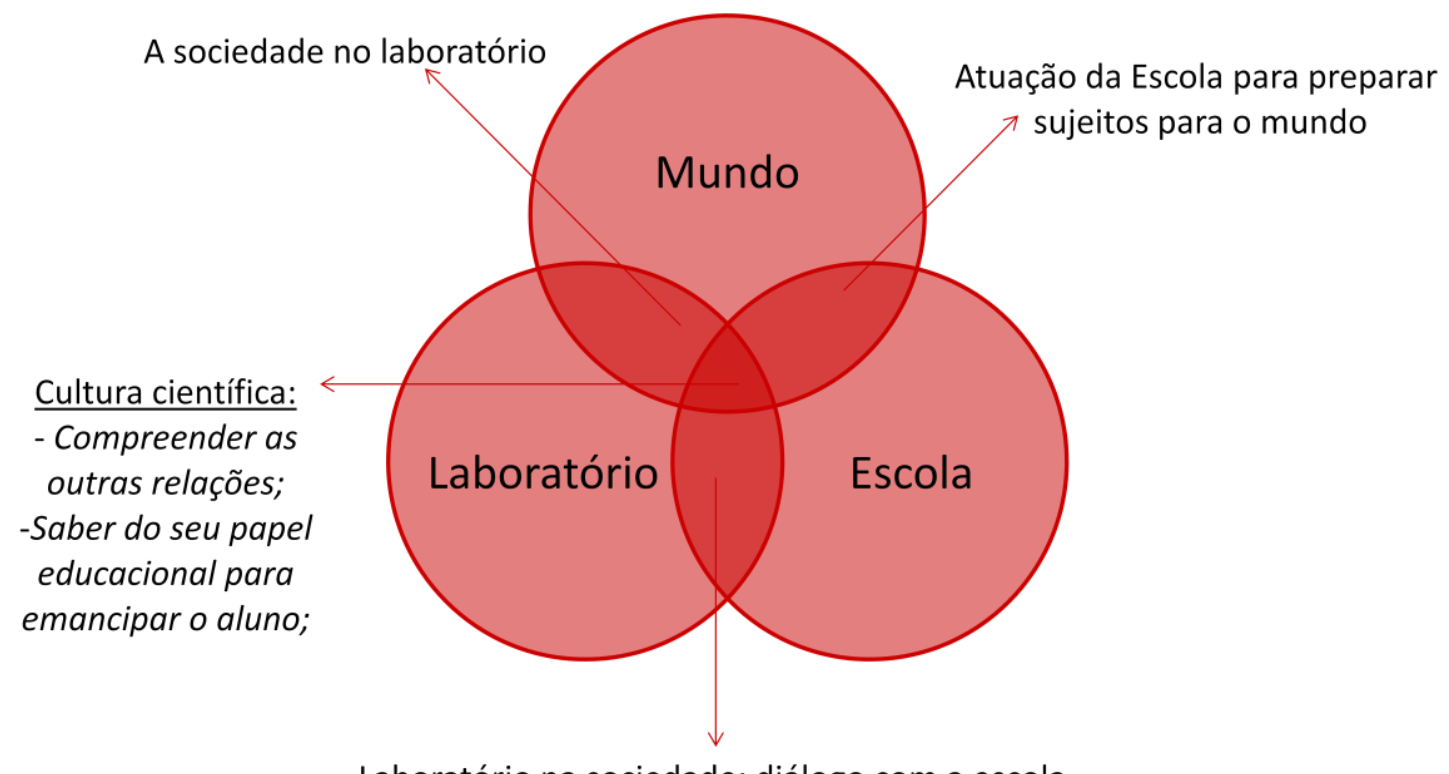

Laboratório na sociedade: diálogo com a escola

Figura 8.4: Campos de Atuação das Instituições

Em síntese, o papel das visitas aos laboratórios é o de promover o diálogo com a sociedade, através da interação com as instituições que formam o mundo exterior a ele e com as quais interage. Na proposta que buscamos, a escola é uma delas, mas existem outras. Trata-se de buscar um diálogo cuidadoso, que reflita a complexidade que envolve essas diversas maneiras de enxergar o mundo. $O$ que se propõe é que essa interação por si só já estabelece o caminho necessário para a construção de olhar mais amplo da escola para a ciência do laboratório e dos sujeitos do laboratório para a escola.

O próximo passo, talvez ousado, é buscar estabelecer a relação entre essas perspectivas de atuação, localizando-as como entreolhares da cultura científica. Essa postura implica em reconhecer, valorizar e articular os interesses dos diversos sujeitos envolvidos nesse processo, como os cientistas, que buscam apresentar e esclarecer sobre suas pesquisas, os professores, que procuram contextualizar os conteúdos ensinados da escola e engajar seus alunos nos estudos sobre ciências, e os estudantes, que procuram olhar para dimensões mais amplas, direcionando seu olhar para a imagem e o lugar de trabalho dos cientistas, para a universidade e suas estruturas, etc. 
Assim, como resultado desse trabalho, foi observado que existem diversas vozes e sentidos atribuídos às visitas ao acelerador Pelletron. Cada uma em seu contexto pode trazer os elementos mais significativos para justificar escolhas e estratégias que possam promover o diálogo entre cientistas e público. De certo modo, essas opções não se mostram erradas ou corretas, pois enfatizam uma perspectiva que se quer priorizar. Também não são únicas, expressando-se de forma diferente em diferentes circunstâncias.

No entanto, como espaços de promoção da educação científica, os laboratórios são importantes meios de debate acerca de temas que estão fora do contexto escolar e que envolvem saberes sobre o fazer da ciência, o conhecimento científico, seus produtos, as interações entre a comunidade científica, a construção do saber coletivo, o saber fazer dos técnicos, os financiamentos, os comitês de éticas, os órgãos de regulamento, etc.

São tais dimensões que devem ser priorizadas nesses espaços, pois enfatizam situações mais amplas de aprendizagem que não se focalizam apenas na aquisição de conteúdos, em geral atribuição idealizada para a escola. Ao contrário, podem facilitar a compreensão sobre aspectos da história da ciência, debates políticos que envolvam discussões de financiamento para pesquisas, ter uma opinião científica sobre um filme, adquirir curiosidade para fazer visitas a outros laboratórios científicos, mobilizar-se para a carreira científica ou optar por um livro de divulgação científica em sua próxima interação com uma livraria. Enfim, podem trazer os alunos ou visitantes para o conhecimento científico através de múltiplos e intrincados caminhos. 


\section{Bibliografia}

\section{Bibliografia}

ABREU, J.C. et al (2004) Nova Bancada da Fonte de Íons do Acelerador Pelletron.In: XXV CBRAVIC. Rio de Janeiro, 2004.

AFONSO, A.J. (1989) Sociologia da Educação Não-escolar: Reactualizar um Objeto ou Construir um Nova Problemática?. In: ESTEVES, A.J. (Org.) A Sociologia na Escola: Professores, Educação e Desenvolvimento. Porto: Afrontamento, 1980.

AIKENHEAD, G. (2003) STS Education: A Rose by Any Other Name. In: CROSS, R. (Org.) A Vision for Science Education. Responding to the Work of Peter Fensham. Canadá: RoutledgeFalmer, 2003.

AIRES, J.A. \& LAMBACH, M. (2010) Contextualização do Ensino de Química pela Problematização e Alfabetização Científica e Tecnológica: uma Possibilidade para a Formação Continuada de Professores. In: Revista Brasileira de Pesquisas em Educação em Ciências, v.10, n.1, p. 1-16, 2010.

ALMEIDA, M.J.P.M. (2010) O Texto de Divulgação Científica como Recurso Didático na Mediação do Discurso Escolar Relativos à Ciência. In: PINTO, G.A. (Org.) Divulgação Científica e Práticas Educativas. Curitiba: Editora CRV, 2010.

AULER, D. (2003) Alfabetização Científico-Tecnológica: um Novo "Paradigma"?. In: Ensaio - Pesquisa em Educação em Ciências, v.5, n. 1, 2003.

AULER, D. \& BAZZO, W.A. (2001) Reflexões para a Implementação do Movimento CTS no Contexto Educacional Brasileiro. In: Revista Ciência \& Educação, v.7, n.1, p. 1-13, 2001.

AULER, D. \& DELIZOICOV, D. (2001) Alfabetização Científico-Tecnológica Para Quê? In: Ensaio - Pesquisa em Educação em Ciências, v. 3, n. 1, 2001.

BARBOUR, R. (2008) Grupos Focais. Porto Alegre: Artmed, 2009.

BELLIZIA, A.P. et.al. (2010) O Método como Caminho e o Caminho como Método: o Habitus de Consumo de Estudantes Paulistanos. In: Revista Olhar de Professor, v.13, n.2, p. 239-253, 2010. 
BEZERRA, S. (2000) Do Assistencial ao Educacional: por uma Fundamentação Filosófica da Educação Não-Formal. 2000,120 f. Dissertação de Mestrado (Faculdade de Educação) Universidade Estadual de Campinas, 2000.

BONADIMAN, H. et.al. (2005) Difusão e Popularização da Ciência: uma Experiência em Física que deu Certo. In: Atas do XVI Simpósio Nacional de Ensino de Física, Vitória - ES, 2005.

CARLIN, N. (1983) Determinação de Parâmetros de Densidade de Níveis para Núcleos na Camada s-d. 1983. 129 f. Dissertação (Mestrado em Ciências) Instituto de Física, Universidade de São Paulo, 1983.

CARUSO, F. \& OGURI, V. (2006) Física Moderna: Origens Clássicas e Fundamentos Quânticos. Rio de Janeiro: Elsevier, 2006.

CAZELLI, S. \& COIMBRA, C.A.Q. (2008) Avaliação Formal na educação Não Formal. In: Quarta reunião anual da Associação de Avaliação Educacional, 2008.

CAZELLI, S. et. al. (1999) Tendências Pedagógicas das Exposições de um Museu de Ciência. In: Seminários de Implantação de Centros e Museus de Ciência. Rio de Janeiro: 1999.

CHAGAS, I. (1993) Aprendizagem Não Formal/Formal das Ciências: Relações entre Museus de Ciência e Escolas. In: Revista de Educação, v.3, n.1, p. 51-59, 1993.

CHASSOT, A. (2000) Alfabetização Científica: Questões e Desafios para a Educação. Rio Grande do Sul: Unijuí, 2000.

. (2003). Alfabetização Científica: Uma Possibilidade para a Inclusão Social.

In: Revista Brasileira de Educação. v.1, n.22, p. 89-100, 2003.

CHINELLI, M.V. \& AGUIAR, L.E.V. (2009) Experimentos e Contextos nas Exposições Interativas dos Centros e Museus de Ciências. In: Investigações em Ensino de Ciências, v.14, n.3, p. 377-392, 2009.

CHIZZOTTI, A. (2003) A Pesquisa Qualitativa em Ciências Humanas e Sociais: Evolução e Desafios. In: Revista Portuguesa de Educação, v. 16, n.16, p. 221-226, 2003.

COLOMBO JR, P.D. et al (2009) Educação em Centros de Ciência: Visita Escolares ao Observatório Astronômico do CDCC/USP. In: Investigações em Ensino de Ciências, v.14, n.1, p. 25-36, 2009. 
COLOMBO JR, P.D. \& SILVA, C.C. (2009) Ensino de Física e Centros de Ciências: um olhar sobre as visitas de alunos do Ensino Fundamental ao observatório astronômico do CDCC/USP. In: XVIII Simpósio Nacional de Ensino de Física, Vitória: Atas do SNEF, 2009.

COUTINHO-SILVA, R. et al (2005) Interação Museu de Ciências-Universidade: Contribuições para o Ensino Não-Formal de Ciência. In: Revista Ciência e Cultura, v.3, p. 120-123, 2005.

DELIZOICOV, D.; ANGOTTI, J. A.; PERNAMBUCO, M. M. (2002) Ensino de Ciências: Fundamentos e Métodos. São Paulo: Cortez, 2002.

DÍAZ, J.A.A.; ALONSO, A.V. \& MAS, M.A.M. (2003) Papel de la Educación CTS en uma Alfabetización Científica y Tecnológica para todas las Personas. In: Revista Electrónica de Enseñanza de las Ciência, v.2, n.2, p. 80-111, 2003. DURANT, J. (1993) O que é Alfabetização Científica. In: MASSARANI, L. et.al. (Org.) Terra Incógnita: a Interface entre Ciência e Público. Rio de Janeiro: Vieira \& Lent, p. 13-26, 2005.

DIB, C.Z. (1988) Forma, Non-formal and Informal Education. In: Cooperative Networks in Physics Education - Conference Proceedings. Nova York: American Institute of Physics, 1988.

ESHACH, H. (2007) Brinding In-school and Out-school Learning: Formal, NonFormal, and Informal Education. In: Journal Science Education and Technology, v.16, n.2, p.171-190, 2007.

FALCÃO, D. (2010) A Física em Museus e Centro de Ciências. In: GARCIA, N.M.D. et.al. (Orgs.) A Pesquisa em Ensino de Física e a Sala de Aula: Articulações Necessárias. São Paulo: Ed. SBF, 2010.

FAUCHE, A. (2008) Charte du Médiateur Culturel de Musée. In: Associantion Médiation Culturelle. Suiça: 2008.

FENSHAM, P. J. (2002) Time to Change Drivers for Scientific Literacy. In: Canadian Journal of Science, Mathematics and Technology Education, v. 2, n. 1, p. 9-24, 2002.

FLICK, U. (1995) Introdução as Pesquisa Qualitativa. São Paulo: Artmed, 2009. FORQUIN, J.C. (1993) Escola e Cultura: as Bases Sociais e Epistemológicas do Conhecimento Escolar. Porto Alegre: Artmed, 1993. 
FOUREZ, G. (1994) Alfabetización Científica y Tecnológica: Acerca de las Finalidades de la Enseñanza de las Ciencias. Argentina: Colihue, 2010. . (2006) Educar: docentes, alunos, escolas, éticas, sociedades. São Paulo: Ideias \& Letras, 2008.

FREIRE, P. (1987) Pedagogia do Oprimido. Rio de Janeiro: Paz e Terra, 1987.

FREITAG, B. (1979) Prefácio. In: MOREL, R.L.M. (Org.) Ciência e Estado: a Política Científica no Brasil. São Paulo: T.A. Queiroz, 1979.

GADOTTI, M. (2005) A Questão da Educação Formal/Não-Formal. In: Droit à l'éducation: solution à tous lês problèmes ou problème sans solution?, Institut International des droits de l'enfante, Suisse, 2005.

GARCIA, L.V.S. (2009) A Física Moderna e Contemporânea no Ensino Médio: Caminhos para a Sala de Aula. 2009. 219 f. Dissertação (Mestrado em Ensino de Física) - Instituto de Física - Faculdade de Educação, Universidade de São Paulo, 2009.

GARCIA, M.I.G.; CEREZO, J.A.L. \& LUJÁN, J.L. (1996) Ciência, tecnologia y sociedad: Uma introducción al estudio social de la ciência y la tecnolgía. Madrid: Tecnos, 1996.

GARCIA, V.A. (2009) A Educação Não-Formal como Acontecimento. 2009, 456 f. Tese de Doutorado (Faculdade de Educação). Universidade Estadual de Campinas, 2009.

GASPAR, A. (1993) Museus e Centros de Ciências: Conceituação e Proposta de um Referencial Teórico. 1993. 118 f. Tese (Doutorado em Educação) Faculdade de Educação, Universidade de São Paulo, 1993.

GERMANO, M.G. \& KULESZA, W. (2007) Popularização da Ciência: uma Revisão Conceitual. In: Caderno Brasileiro de Ensino de Física, v.24, n.1, p. 7-25, 2007.

GHANEM, E. (2008) Educação Formal e Não-Formal: do Sistema Escolar ao Sistema Educacional. In: ARANTES, V.A. (Org.) Educação Formal e NãoFormal. São Paulo: Summus, 2008.

GIL, A.C. (2006) Métodos e Técnicas de Pesquisa Social. São Paulo: Ed. Atlas, 2006.

GONDIM, S.M.G. (2002) Grupos Focais como Técnica de Investigação Qualitativa: Desafios Metodológicos. In: Revista Paideia, 2002. 
GOUVÊA, G. \& LEAL, M.C. (2001) Uma Visão Comparada do Ensino de Ciência, Tecnologia e Sociedade na Escola e em um Museu de Ciência. In: Ciência \& Educação, v.7, n.1, p. 67-84, 2001.

GOUVÊA, G. et al (2001) Redes Cotidianas de Conhecimento e os Museus de Ciência. In: Parcerias Estratégicas, Brasília, №11, p. 169-174, 2001.

GRUZMAN, C. \& SIQUEIRA, V.H.F. (2007) O Papel Educacional do Museu da Ciências: Desafios e Transformações Conceituais. In: Revista Electrónica de Enseñanza de las Ciencias, v.6, n.2, p. 402-423, 2007.

GUISASOLA, J. et al (2005) Diseño de Estrategias Centradas en al Aprendizaje para

las Visitas Escolares a los Museos de Ciencias. In: Revista Eurecka Enseñanza y Divulgación de las Ciencias, v.2, n.1, p.19-32, 2005.

GUTBERLET, J. (2010) Pesquisa Qualitativa: Notas de Aula. In. Faculdade de Educação, USP, 2010.

HARTMANN, A.M, et.al. (2008) O Impacto da Semana Nacional de Ciência e Tecnologia sobre o Conhecimento de Física de Alunos de Ensino Médio. In:

Encontro de Pesquisa em Ensino de Física. Curitiba, 2008.

ICOM (2007) Statutes of International Council of Museums, art. 2\$1, 2007.

JACOBUCCI, D.F.C. (2008) Contribuições dos Espaços Não-Formais de Educação

para a Formação da Cultura Científica. In: Em Extensão, v. 7, p. 55-66, 2008.

LANDREANI, N.F. (1990) Métodos Cuantitativos versus Métodos Cualitativos: Un

Falso Dilema. In: Ciência, Docencia y Tecnologia, v.1, n.1, 1990.

LATOUR, B. \& WOOLGAR, S. (1979) A Vida de Laboratório: a Produção dos Fatos Científicos. Rio de Janeiro: Dumará, 1997.

LAUGKSCH, R.C. (2000) Scientific Literacy: a Conceptual Overview. In: Science Education, v. 84, n.1, p. 71-94, 2000.

LÉVY-LEBLOND, J.M. (2004) La Science en Mal de Culture. Paris: Futuribles, 2004.

LEMKE, J.L. (1993) Aprender a Hablar Ciencia: Lenguaje, Aprendizaje y Valores. Barcelona: Paidós, 1997.

LOIZOS, P. (2002) Vídeo, Filme e Fotografias como Documentos de Pesquisa. In: BAUER, M.W. \& GASKELL, G. (Orgs.) Pesquisa Qualitativa com Texto, Imagem e Som. Petrópolis: Ed. Vozes, 2005. 
LORENZETTI, L. \& DELIZOICOV, D. (2001) Alfabetização Científica no Contexto das Séries Iniciais. In: Ensaio - Pesquisa em Educação em Ciências, v.3, n.1, p. 1-17, 2001.

MACEDO, B. \& KATZKOWICZ, R. (2003) Educação Científica: Sim, mas Qual e Como? In: MACEDO, B. (Org.) Cultura Científica: Um Direito de Todos. Brasília: Unesco, 2003.

MARQUESA, A.L.F. \& SCHEIDEGGERB, A.P.G. (2009) Produção de Materiais de Divulgação Científica nas suas Diversas Mídias. In: XVIII Simpósio Nacional de Ensino de Física. Vitória: 2009.

MARTINS, H.H.T.S. (2004) Metodologia Qualitativa de Pesquisa. In: Educação e Pesquisa, v.30. n.2, p. 289-300, 2004.

MARTINS, I. (2008) Alfabetização Científica: Metáfora e Perspectiva para o Ensino de Ciências. In: XI Encontro de Pesquisa em Ensino de Física, Curitiba, 2008.

. (2010) Letramento Científico: um Diálogo entre Educação em Ciências e Estudos do Discurso. In: MARINHO, M. \& CARVALHO, G.T. (Orgs.) Cultura Escrita e Letramento. Belo Horizonte: UFMG, 2010.

MARTINS, M.C.F.N. \& BÓGUS, C.M. (2004) Considerações sobre a Metodologia Qualitativa como Recurso para o Estudo das Ações de Humanização em Saúde. In: Saúde e Sociedade, v. 13, n.3, p. 44-57, 2004.

MARANDINO, M. et al (2004) A Educação Não-Formal e a Divulgação Científica: o que Pensa Quem Faz? In: Atas do IV Encontro Nacional de Pesquisa em Ensino de Ciência, 2004.

MARANDINO, M. (2007) É Possível Estudar Aprendizagem nos Museus de Ciências? In: NARDI, R. (Org.) A Pesquisa em Ensino de Ciências no Brasil: Alguns Recortes. São Paulo: Escrituras, 2007. . (2004) Transposição ou Recontextualização? Sobre a Produção de Saberes na Educação em Museus de Ciências. In: Revista Brasileira de Educação, n.26, p. 95-108, 2004.

MEDINA, N.H. (1988) Razão Giromagnética de Estados Excitados de ${ }^{107,109} \mathrm{Ag}$. 1988. Dissertação (Mestrado em Ciências) - Instituto de Física, Universidade de São Paulo, 1988. 
MILARÉ, T. \& ALVES FILHO, J.P. (2010) Ciências no Nono Ano do Ensino Fundamental: da Disciplinaridade à Alfabetização Científica e Tecnológica. In: Revista Ensaio, v.12, n.2, p. 101-120, 2010.

MORA, A.M.S. (1998) A Divulgação da Ciência como Literatura. Rio de Janeiro: Editora UFRJ, 2003.

NASCIMENTO, S.S. (2010) A divulgação das Ciências e as Instituições Patrimoniais.

In: PINTO, G.A. (Org.) Divulgação Científica e Práticas Educativas. Curitiba: Editora CRV, 2010.

NASCIMENTO, S.S.; SANTOS, R. \& NIGRI, E. (2006) Alfabetização Científica e Tecnológica e a Interação com os Objetos Técnicos. In: Cadernos Brasileiro de Ensino de Física, v.23, n.1, p. 53-67, 2006.

NEHRING, C.M. et al (2002) As Ilhas de Racionalidade e o Saber Significativo: o Ensino de Ciências Através de Projetos. In: Ensaio - Pesquisa em Educação em Ciências, v.2, n.1, p. 1 - 18, 2002.

OLIVEIRA, M.A. (2010) Alfabetização Científica no Clube de Ciências do Ensino Fundamental: uma Questão de Inscrição. In: Revista Ensaio, v.12, n.2, p. 11 26, 2010.

OSBORNE, J. (2003) A Educação Científica na Sociedade de Hoje: Dificuldades, Questões e Dilemas. In: Gazeta da Física, v.2, n.3, p.13-19, 2003.

PARFITT, J. (2005) Questionnaire Design and Sampling. In: FLOWERDEW, R. \& MARTIN, D. (Ed.) Methods in Human Geography: A Guide for Students Doing a Research Project. Inglaterra: Pearson Education, p. 78-109, 2005.

PÉREZ, C.A. \& MOLINÍ, A.M.V. (2004) Consideraciones Generales Sobre la Alfabetización Científica en los Museos de la Ciência como Espacios Educactivos no Formales. In: Revista Electrónica de Enseñanza de las Ciencias, v.3, n.3, p. 339-362, 2004.

PINTO, A.C \& ZANETIC, J. (1999) É possível levar a física quântica para o ensino médio? In: Caderno Catarinense de Ensino de Física, v.16, n.1, 1999.

POZO, J.I. \& CRESPO, M.A.G. (2006) A Aprendizagem e o Ensino de Ciências: do Conhecimento Cotidiano ao Conhecimento Científico. Porto Alegre: Artmed, 2009. 
PRAIA, J.; GIL-PÉREZ, D. \& VILCHES, A. (2007) O Papel da Natureza da Ciência na Educação para a Cidadania. In: Ciência \& Educação, v.13, n.2, p.141156, 2007.

QUEIRÓZ, G. et. al. (2002) Construindo Saberes de Mediação na Educação em Museus de Ciências: o Caso dos Mediadores do Museu de Astronomia e Ciências Afins/Brasil. In: Atas do I Encontro Ibero-Americano sobre Investigação em Educação em Ciências. Espanha: Burgos, p. 16-21, 2002.

QUEIRÓZ, G. (2010) A Colaboração entre Museus e a Escola: a Pesquisa, o Ensino e a Popularização da Ciência. In: GARCIA, N.M.D. et.al. (Orgs.) A Pesquisa em Ensino de Física e a Sala de Aula: Articulações Necessárias. São Paulo: Ed. SBF, 2010.

RICHETTI, G.P. \& ALVES FILHO, J.P. (2009) Automedicação: um Tema Social para - Ensino de Química na Perspectiva da Alfabetização Científica e Tecnológica. In: Alexandria - Revista de Educação em Ciência e Tecnologia, v.2, n.1, p. 85-108, 2009.

ROCHA, M. \& GARCIA, N.M.D. (2008) Educação Científica na Parceria entre o Museu de Ciências e a Escola nas Séries Iniciais do Ensino Fundamental: Reflexões sob o Olhar da Alfabetização Científica Ampliada. In: Atas do XI Encontro de Pesquisa em Ensino de Física. Curitiba: Sociedade Brasileira de Física, 2008.

SANTOS NETO, E. R. (2007) Física no Brasil para o ensino médio: uma Abordagem para Compreensão da Ciência e da Atividade Científica. 2007. 193 f. Dissertação (Mestrado em Ensino de Ciências) - Instituto de Física, Universidade de São Paulo, 2007.

SANTOS, M.E.V.M. (2001) A Cidadania na "Voz" dos Manuais Escolares. Lisboa: Horizontes, 2001.

- (2005) Cidadania, Conhecimento, Ciência e Educação CTS: Rumo a “Novas” Dimensões Epistemológicas. In: Revista CTS, v.2, n.6, p. 137-157, 2005.

SANTOS, W.L.P \& MORTIMER, E.F. (2002) Uma Análise de Pressupostos Teóricos da Abordagem C-T-S (Ciência - Tecnologia - sociedade) no Contexto da Educação Brasileira. In: Ensaio - Pesquisa em Educação em Ciências, v.2, n.2, p. 1-23, 2002. 
SESSLER, A. \& WILSON, E. (2007) Engines of Discovery: A Century of Particles Accelerators. Zurich: World Scientific, 2006.

SILVA, E.L. (2002) A Construção do Conhecimento Científico: o Processo, a Atividade e a Comunicação Científica em um Laboratório de Pesquisa. In: Perspectiva em Ciência da Informação, v. 7, n.2, p. 109-125, 2002.

SILVA, H.C. (2006) O que é Divulgação Científica? In: Ciência \& Ensino, v.1, n.1, p. 53-59, 2006.

SILVERMAN, D. (2006) Interpretação de Dados Qualitativos: Métodos para Análise de Entrevistas, Textos e Interações. São Paulo: Artmed, 2009.

SIQUEIRA, M.R.P. (2006) Do Visível ao Indivisível: uma Proposta de Física de Partículas Elementares para o Ensino Médio. 2006. 257 f. Dissertação (Mestrado em Ensino de Ciências) - Instituto de Física, Universidade de São Paulo, 2007.

SOARES, M. (2003) Alfabetização e Letramento. São Paulo: Contexto, 2011.

STRIEDER, R. (2008) Abordagem CTS e Ensino Médio: Espaços de Articulação. 2008. 236 f. Dissertação (Mestrado em Ensino de Ciências) - Instituto de Física, Universidade de São Paulo, 2008.

TEIXEIRA, J. N.; MURAMATSU, M. \& ALVES, L. A. A. (2010) Uma abordagem de divulgação científica interativa em espaços abertos. In: Caderno Brasileiro de Ensino de Física, v. 27, p. 171-187, 2010.

TOHARIA, M. \& FRUTOS, E.L. (2004) Divulgación y educación científica en la escuela y en los centros interactivos de la ciencia. In: VILA, F.J.R. \& OTAOLA, I.F.J.S.C. (Orgs.) Percepción Social de la Ciencia. Espanha: Academia Europea de Ciencias y Artes, 2004.

TRAWEEK, S. (1988) Beamtimes and Lifetimes: the World of High Energy Physicists. Massachusetts: Harvard Press, 1988.

TRILLA, J. (2008) A Educação Não-Formal. In: ARANTES, V.A. (Org.) Educação Formal e Não-Formal. São Paulo: Summus, 2008.

TRIVIÑOS, A.N.S. (1987) Introdução à Pesquisa em Ciências Sociais: a Pesquisa Qualitativa em Educação. São Paulo: Atlas, 1987.

VIANNA, D.M. (1998) Do Fazer ao Ensinar Ciência. 1998. 188 f. Tese (Doutorado em Educação) - Faculdade de Educação, Universidade de São Paulo, 1998. 
. (1996) Da Criação à Difusão: A Ciência que Ensinamos. In: Pro-Posições, v.7, n. 1[19], p. 95-102, 1996.

. (2001) Bruno Latour e Contribuições da Antropologia da Ciência: Aspectos para o Ensino de Ciências. In: Ciência \& Ensino, v.1, n.10, p. 14-19, 2001.

VIANNA, D.M. \& CARVALHO, A.M.P. (2000) Formação Permanente: a Necessidade de Interação entre a Ciência dos Cientistas e a Ciência da Sala de Aula. In: Ciência e Educação, v.6, n.1, p. 31-42, 2000.

. (2001) Do Fazer ao Ensinar Ciência: a Importância dos Episódios de Pesquisa na Formação de Professores. In: Investigações em Ensino de Ciências, v.6, n.2, p. 111-132, 2001.

VILLARI, A.C.C. (1982) Contribuição ao Estudo do Espalhamento Elástico do Sistema ${ }^{12} \mathbf{C}+{ }^{28}$ Si. 1982.100 f. Dissertação (Mestre em Ciências) - Instituto de Física, Universidade de São Paulo, 1982.

WAGENSBERG, J. (2004) Los Museos de la Ciencia: Espacios de Encuentro para la Creación de Opinión Pública. In: VILA, F.J.R. \& OTAOLA, I.F.J.S.C. (Orgs.) Percepción Social de la Ciencia. Espanha: Academia Europea de Ciencias y Artes, 2004.

WATANABE-CARAMELLO, G. \& KAWAMURA, M.R.D. (2008) Inserção de Temas Ambientais no Currículo de Física. In: Noveno Simposio de Investigación en Educación en Física. Argentina, 2008. 


\section{Anexos}




\section{Anexo I - Produção dos professores}

\section{Grupo I}

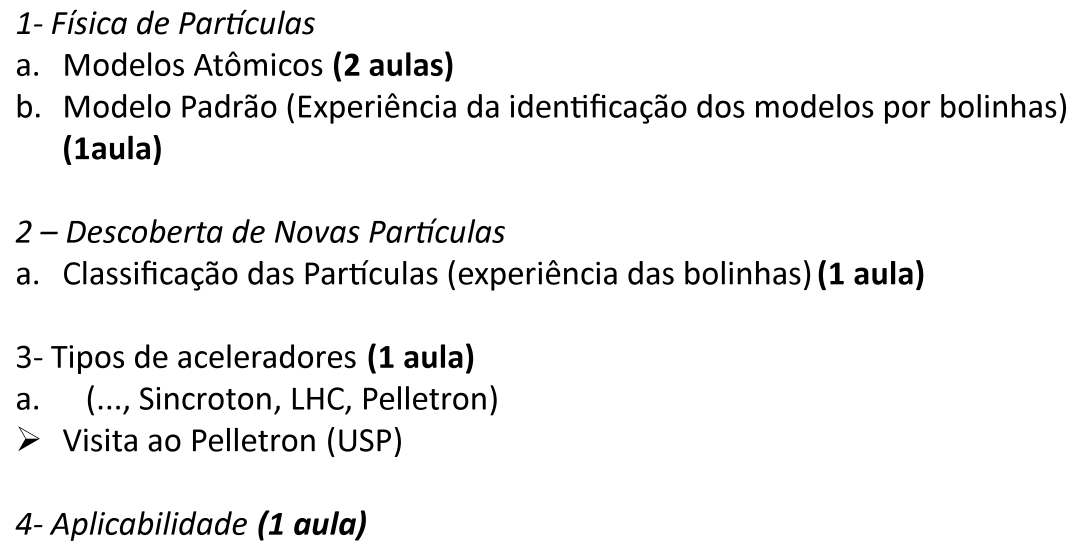

a. Modelos Atômicos (2 aulas)

b. Modelo Padrão (Experiência da identificação dos modelos por bolinhas) (1aula)

2 - Descoberta de Novas Partículas

a. Classificação das Partículas (experiência das bolinhas) (1 aula)

3- Tipos de aceleradores (1 aula)

a. (..., Sincroton, LHC, Pelletron)

$>$ Visita ao Pelletron (USP)

4- Aplicabilidade (1 aula)

\section{1-Física de Partículas}

a. Modelos Atômicos ( 2 aulas)

Com enfoque histórico . (aula da Apostila 3obim)

- Modelos Atômicos: Tales, Demócrito, Leucipo, Dalton, Thomson, Rutherford, Chadwich e Bohr.

- Modelos orbitais: modelo de Bohr, modelo Borh - summerfeld (orbita elíptica)

- Espectro de luz visível e dualidade onda partícula.

- Efeito fotoelétrico

b. Modelo Padrão (Experiência da identificação dos modelos por bolinhas) (1aula) 


\section{2 - Descoberta de Novas Partículas (2 aulas)}

Classificação das Partículas (...)

Hadrons, Mésons e Leptons

E a experiência das bolinhas:
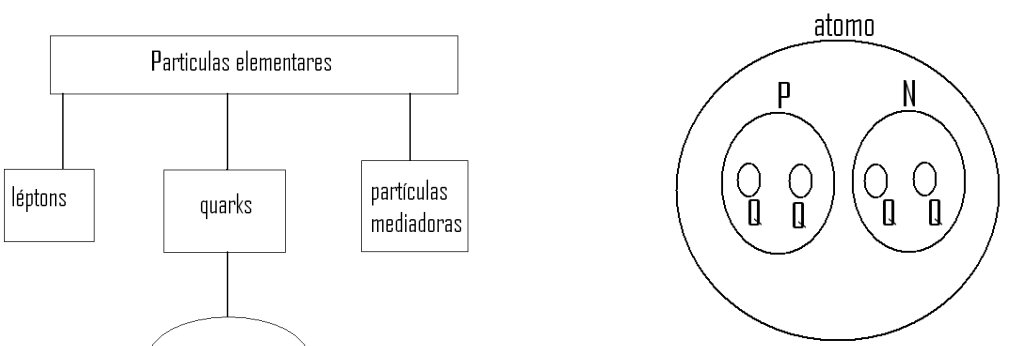

3- Tipos de aceleradores (1 aula)

(entre outros)

Van der Graaff

Sincroton

Feixe de Colisão (LHC e Pelletron)

$>$ Visita ao Pelletron 
4- Aplicabilidade (1 aula)

Exemplos:

Carbono 14, Raio X, Remédios, alimentos, entre outros.

Grupo 2

- Discutir o papel da ciência na sociedade

- Introduzir os conceitos de Física de Partículas

- Discutir a natureza da ciência

- Propiciar ao aluno na fase final de seus estudos uma visão da Física Moderna 
- Leitura de textos de divulgação científica.

- Cinco textos selecionados pelo professor

Lidos em grupos.

- Discussão orientada

- Questões centrais

- Para que grandes investimentos na ciência?

O que é um acelerador de partículas?

O que é a física de partículas?

$>$ Ensino de Física - Introdução às partículas

$>$ Evolução do modelo atômico

> Modelo padrão do átomo

$>$ Experimento de Identificação dos Modelos do Átomo (bolinhas) ${ }^{1}$ 
- Visita ao Pelletron

- O funcionamento do Pelletron

- Pesquisas realizadas no Pelletron

- Os pesquisadores brasileiros de Física de Partículas

- Introdução as partículas elementares

- Profissão pesquisador em Física de Partículas

- Método científico

- O método que acreditavam ser adequado é o das colisões em aceleradores/colisores de alta energia ("A física dos quarks e a epistemologia" Revista Brasileira de Ensino de Física, v. 29, n. 2, p. 161 173, 2007)

Sugestão: Vídeo do RAP DO LHC 
- Atividade escrita (carta)

- Elaboração de uma carta direcionada ao laboratório aberto de Física Nuclear.

- Considerações sobre a visita ao Pelletron

- Conceitos adquiridos

Grupo 3

\section{TRABALHO COM TEMA NO ENSINO DE FÍSICA}

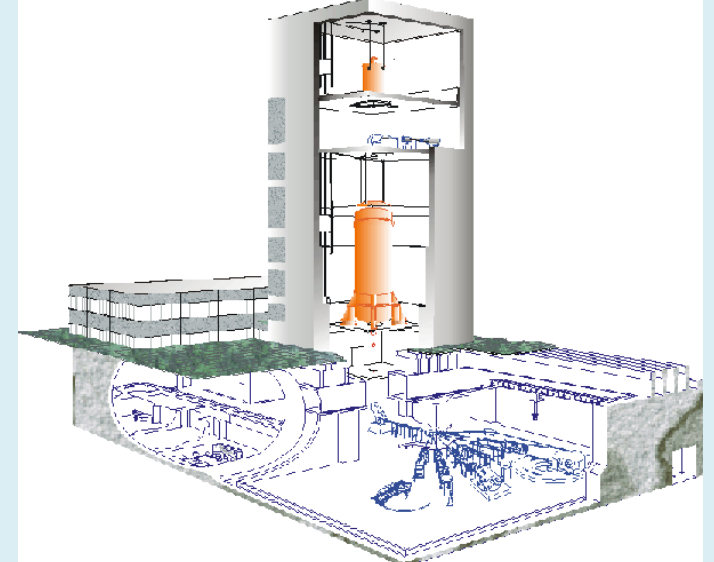

PELLETRON ACELERADOR DE PARTÍCULAS 


\section{Pelletron}

Espaços curriculares:

- Composição química

- Grandezas físicas - dimensões

- Cinemática - Tempo, Velocidade, Aceleração

- Vetores - Posição e trajetória de partículas

- Eletromagnetismo

- Eletricidade

- Radioatividade

- Termodinâmica

- Supercondutividade (Ímãs)

- Hidrostática - Pressão

- Física moderna

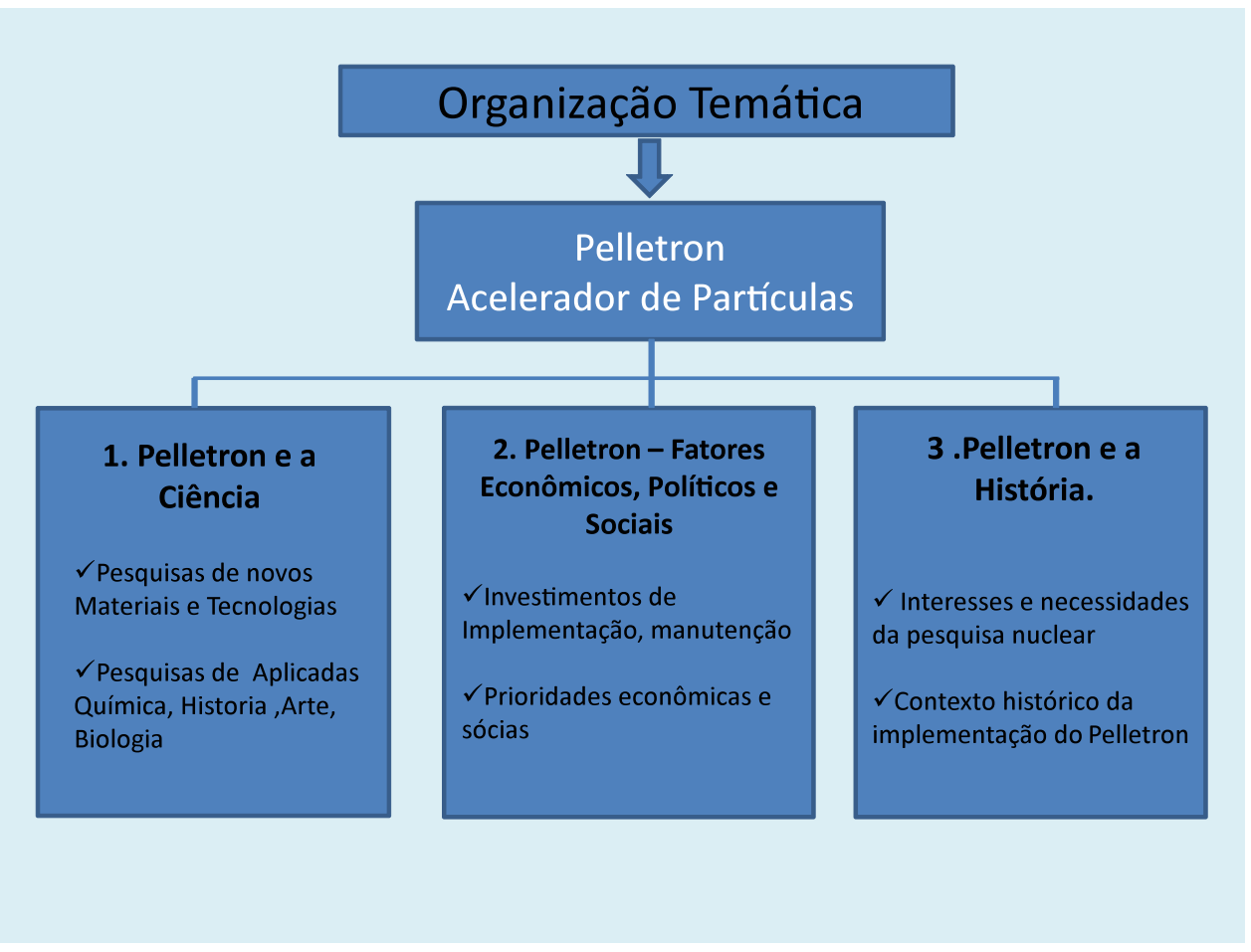




\section{Organização conceitual}

$\sqrt{2}$

Radioatividade (3a SÉRIE E.M.)

1. Elementos
Radioativos
-O que é radioatividade?
-Tabela Periódica
-Extração de minério e
enriquecimento.
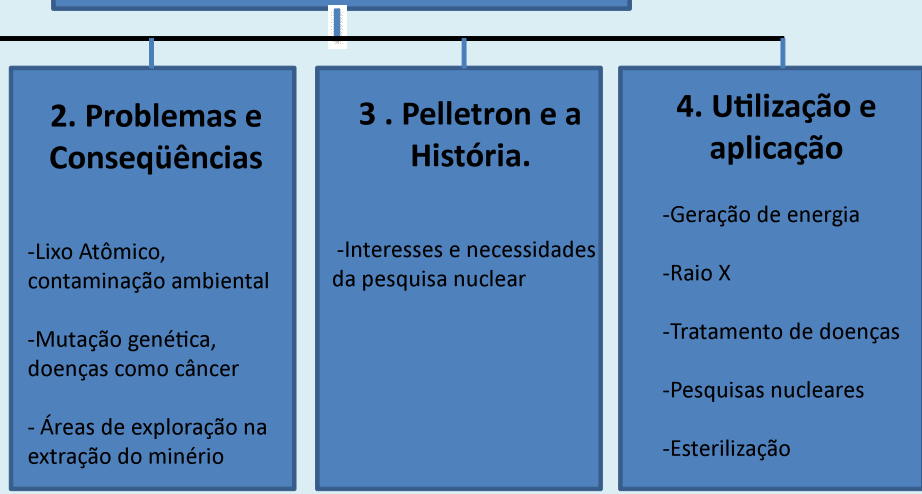

\section{RADIOATIVIDADE}

\section{Radioaditividade no Pelletron}

\section{QUESTÕES}

1. Podemos afirmar que a radiação e radioatividade são sinônimos? Justifique.

2. Quais são as radiações nocivas à saúde?

3. No nosso cotidiano estamos expostos a radioatividade? Justifique

4. A radiação e radioatividade podem ser visíveis?

5. Cite três aplicações da radioatividade?

6. A energia nuclear oriunda de uma explosão atômicas pode ser controlável?

7. Existe uma possibilidade de controlar a energia atômica?

8. Com a poluição ambiental através do lixo, estamos contaminando o nosso lençol freático e dos rios, com materiais radioativos e pesados, e com a ajuda do Pelletron poderíamos analisar minuciosamente a composição da amostra, encontrando qualquer tipo de material por menor que seja. Cite duas novas situações que pudesse ser utilizada o Pelletron. 


\section{RADIOATIVIDADE}

Radioaditividade no Pelletron

Objetivo:

nortear os alunos para as definições de radiação e

radioatividade, bem como a aplicação do Pelletron em pesquisas

Tempo Previsto:

6 aulas, entre pesquisa, discussão e visita ao

laboratório (acelerador de partículas)

\section{Grupo 4}

\section{ENCONTRO IFUSP-ESCOLA}

Física de partículas e física nuclear: Uma visão através dos aceleradores de partículas 


\section{Proposta de aulas}

- Para tratar esse tema propusemos um estudo de caso.

- Porque do estudo de caso?

- O propusemos com o intuito de fornecer ao aluno um modo amigável de introduzir o tema, contemplando a taxionomia do aluno e pensando em fornecer um conhecimento significativo.

\section{A proposta}

- Apresentação do caso

- Visita

- Avaliação 


\section{O caso proposto}

- Uma cidade do interior irá receber um Campus de uma renomada universidade internacional, esta universidade propõem ao prefeito a instalação de um acelerador de partículas. Mas suas verbas são suficientes para custear a metade da instalação. O prefeito solicita uma semana para avaliar a proposta.

\section{O caso proposto}

- Imagine que você seja o prefeito desta cidade. Levante questões para a pauta desta reunião.

Nesta pauta deve estar discutidas as questões referentes à economia, política e demais questões sociais. Lembrando que as verbas extrapolam 0 orçamento previsto para educação. A verba para a instalação do acelerador equivale a $40 \%$ da verba total do município.

Pense nos riscos para a população do município e os benefícios gerados. 
Grupo 5

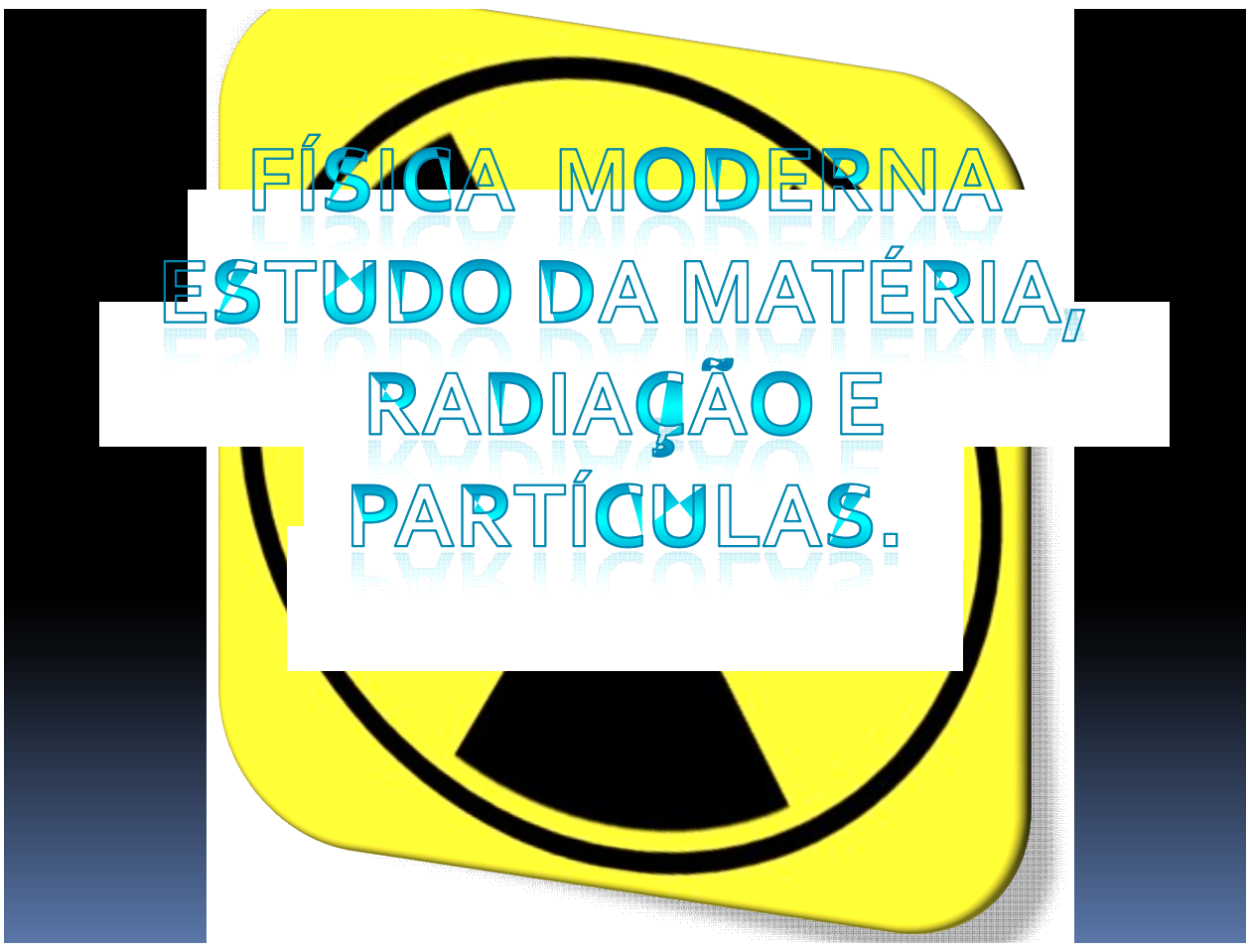

SITUAGẼ̃ES-PARAABORDAR

COM ALUNOS O) TEMA

RADIOATIVIDADE E
ESTUDOC DAS PARTIICULAS:

- UM "0MAÜ NECESSARRIO

ESTUDO CRONOLÓGICO DA

RADIACAO E DAS PARTÍCULAS:

- EEEMTOS BIOLÓGICOS EAS

DIVERSAS APLICACÕES

-(POSITIVAS E EEGATIVAS):

- VECNOLOGIAS

DESENVOLVIDAS:

*PRODUÇÃO DE ENERGMA: * PESQUISAS CIENTIIFUAS - NACOONALS (PELLETRON=IFUSP)

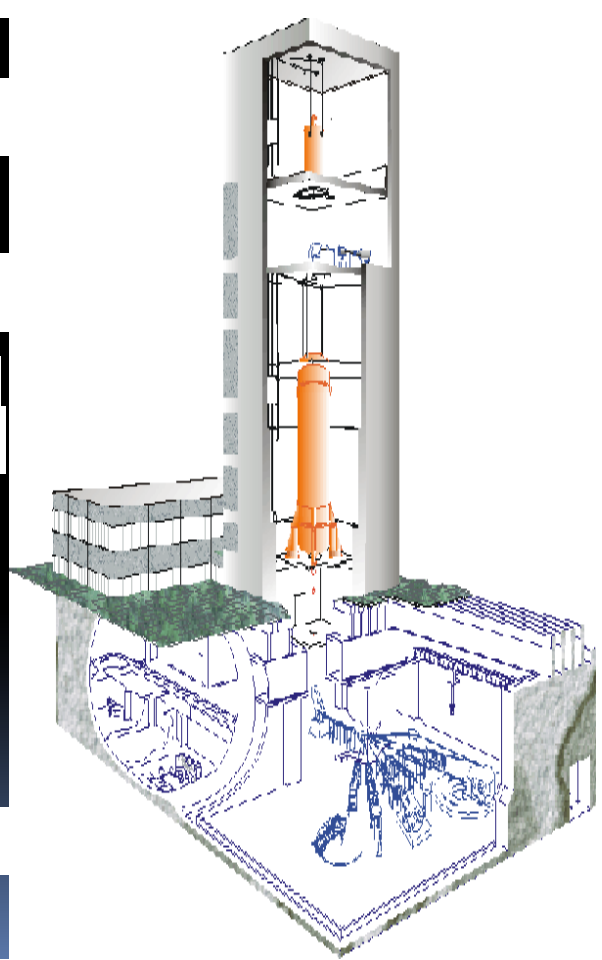



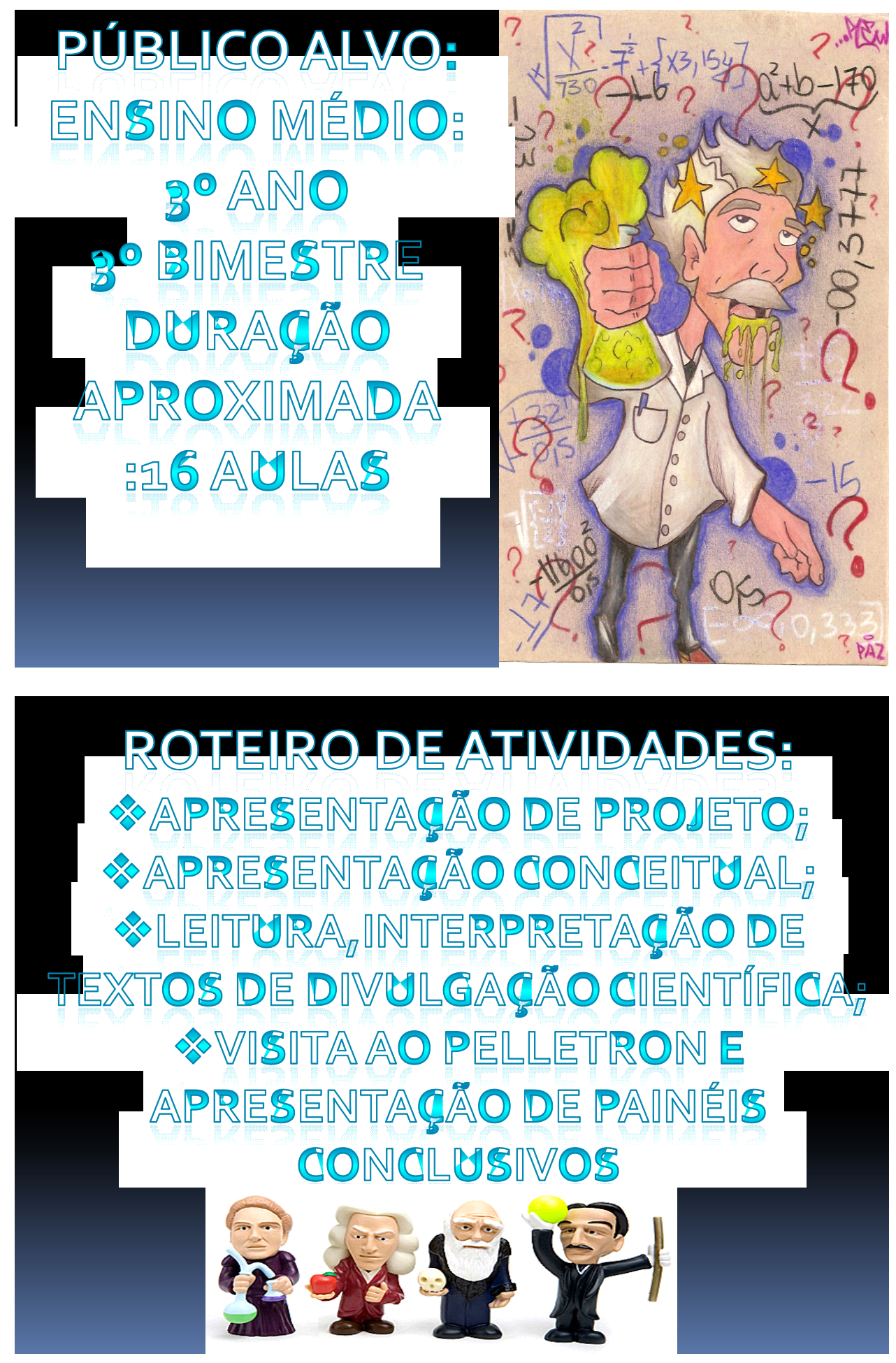


\section{APRESENTAÇÃODO PROS局(O:}

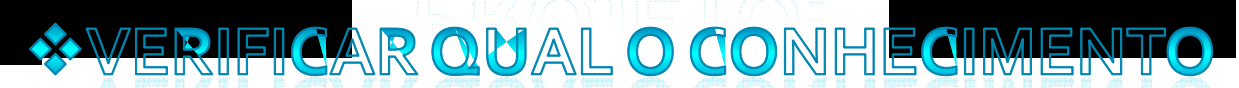
PREVIO SORRE OTEMA ADRESENTARAOS ALUNOS ALG GINAG FUGURAS RELACIONADAS.

* MONTAGEM DERESUMO TEÓRIRO SORRE OTEMAA APRESENTAGARO DE TRECHOS DE DOCUMENTARIOS AFINS COM POSTERIOR DISCUSSAO

\section{APRESENTAÇÃOGONGEITUAL:}

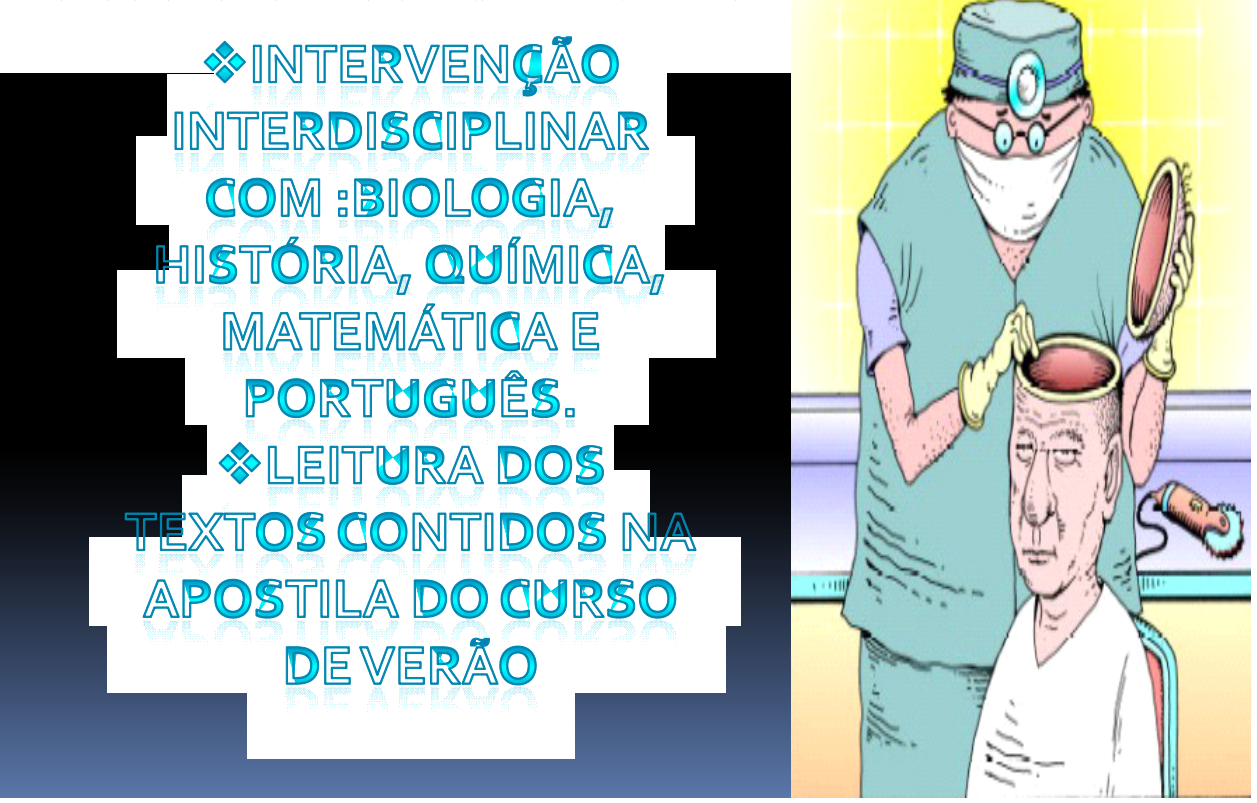



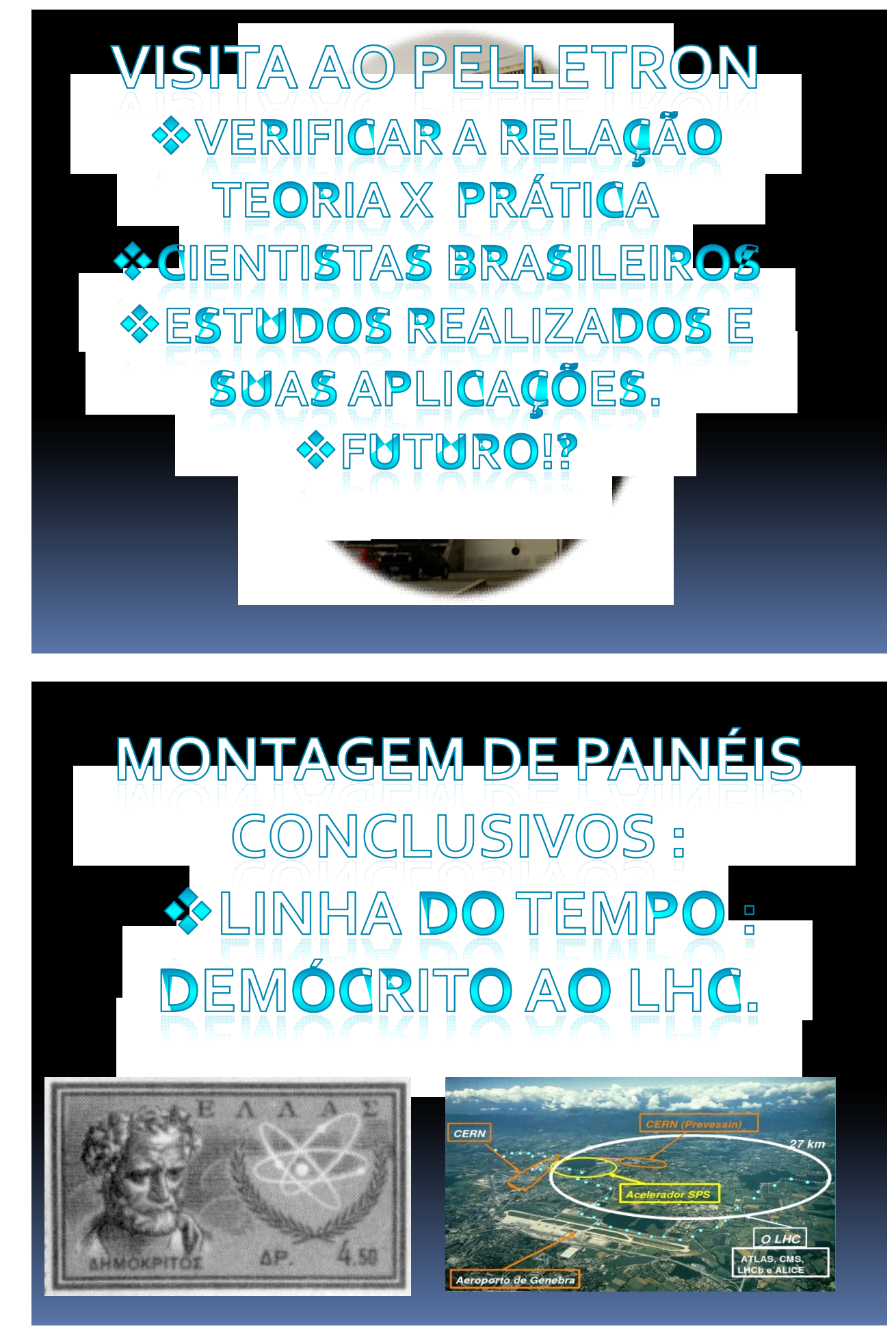

Grupo 6

Uso da Física na Inserção do Acelerador Pelletron

Estudo de partículas a partir de choque de núcleos 


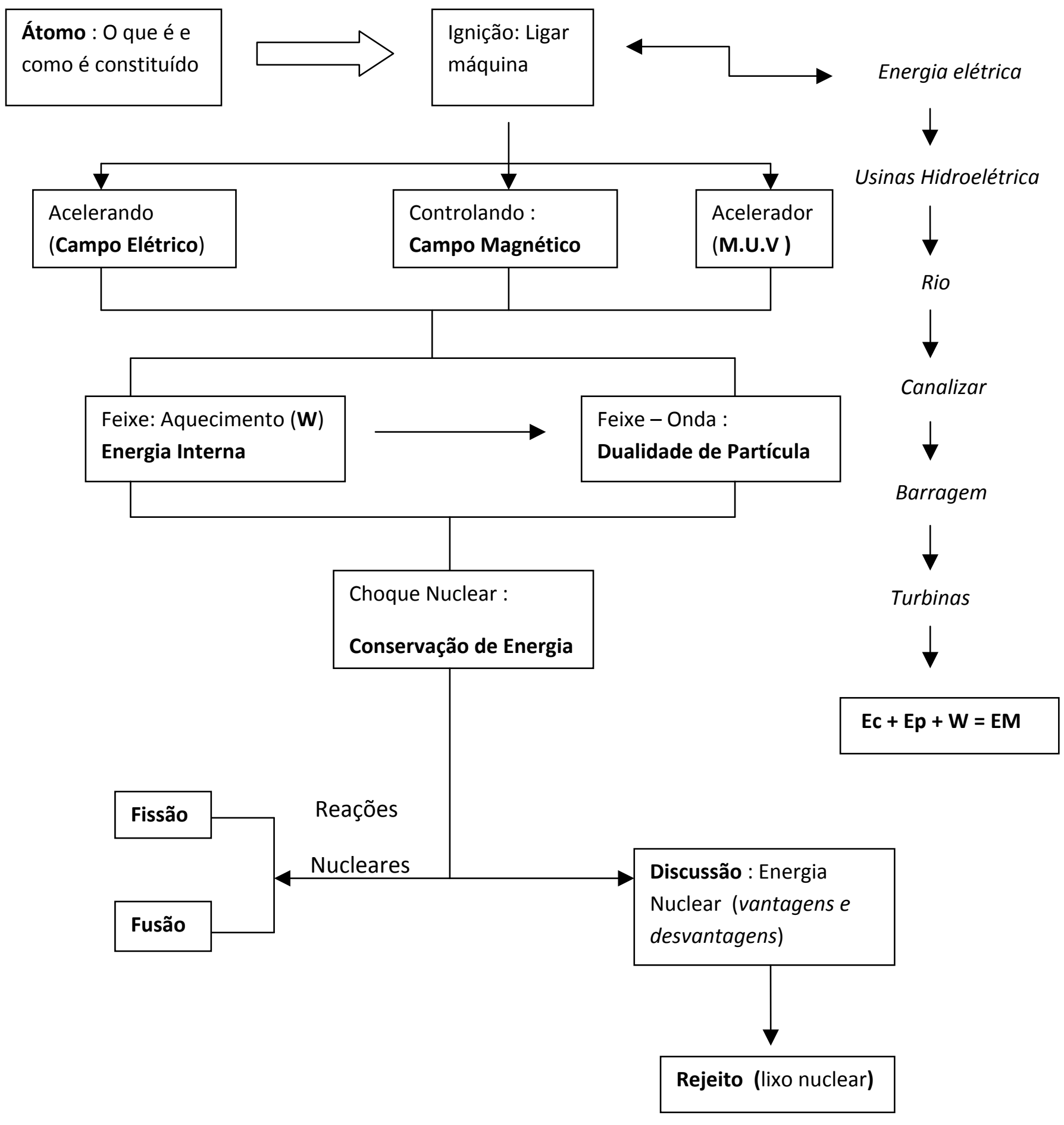

Uso interativo do assunto Pelletron em sala de aula, interligando o acelerador a utilização de energia nuclear e termos utilizados na física, como campo magnético,ondas,energia cinética, energia potencial, energia mecânica, trabalho e física nuclear e debate em sala de aula sobre a utilização da energia nuclear. 


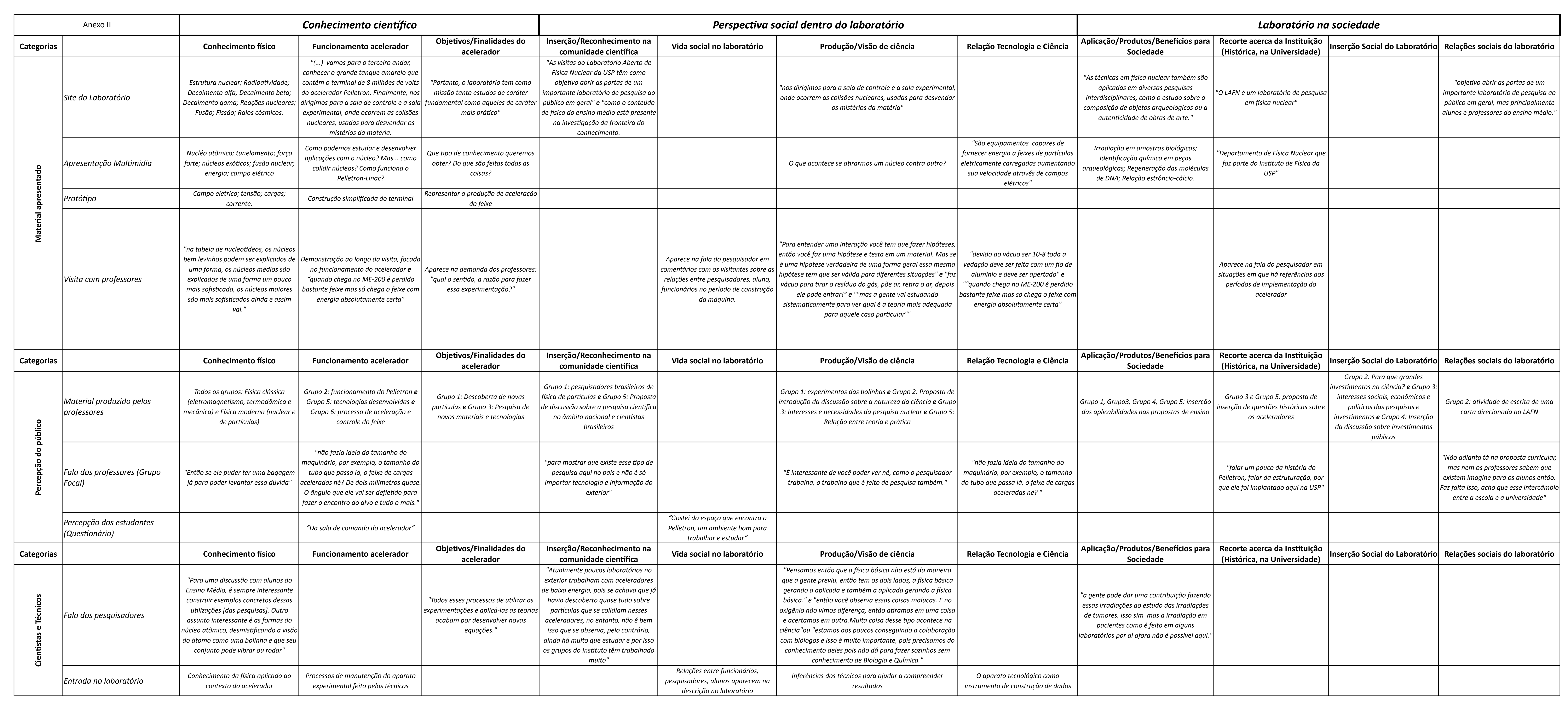




\begin{tabular}{|c|c|c|c|c|c|c|c|c|c|c|c|c|}
\hline AnexollI & & \multicolumn{4}{|c|}{ Sabereses compartithados com a essola } & \multicolumn{3}{|c|}{ Saberes compartilhados da e scola com a educacaño em ciênncias } & \multicolumn{4}{|c|}{ Saberes do museu } \\
\hline categorias & & Saber discipininar & \begin{tabular}{|c|c|c|} 
Saber da transposiçăo \\
didáticas
\end{tabular} & Saber do dialilogo & Saber da linguagem & Saber da historoia da ciência & Saber da višão da ciência & Saber das concepş̄es alternativas & $\begin{array}{c}\text { Saber sobre a historia da } \\
\text { instituigaso }\end{array}$ & $\begin{array}{l}\text { Saber da interacăä como o } \\
\text { professor }\end{array}$ & Saber da conexão & $\begin{array}{c}\text { Saber da historia da } \\
\text { humanidade }\end{array}$ \\
\hline 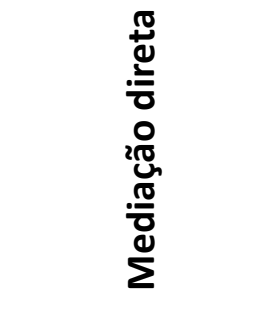 & Visita com professores & 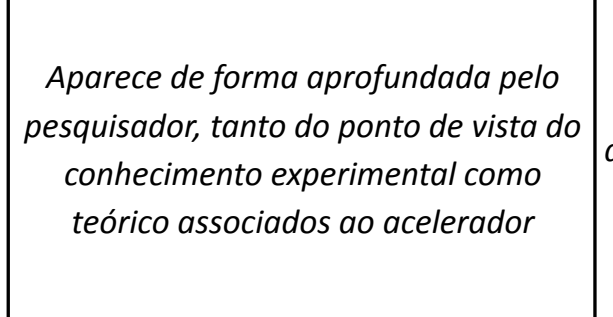 & 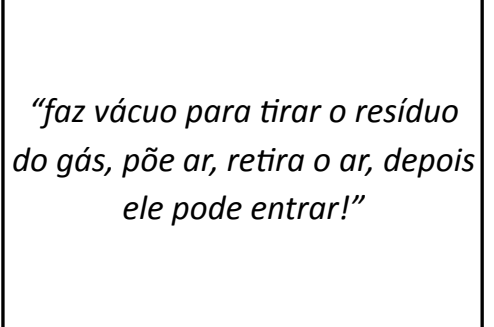 & 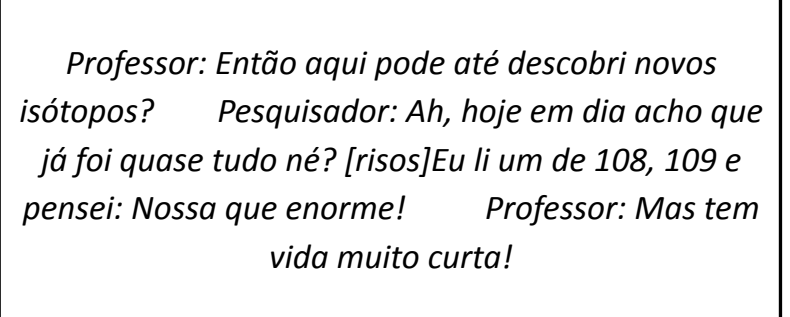 & & & & & 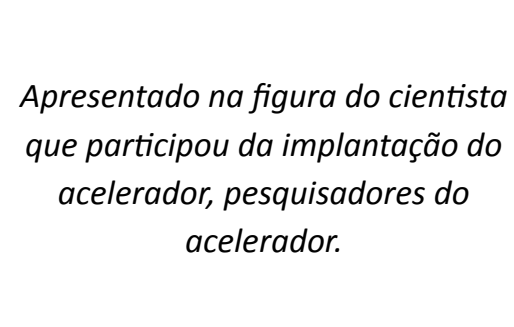 & & 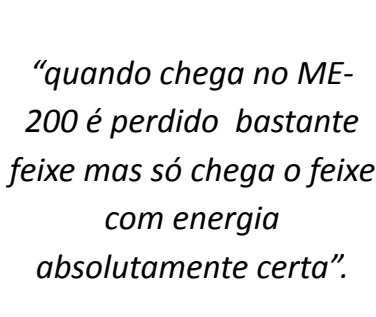 & \\
\hline Categorias & & Saber discipininar & 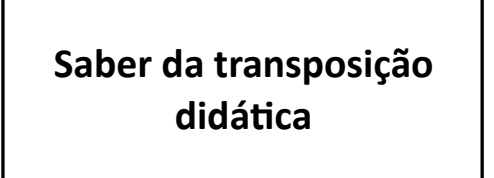 & Saber do dialilggo & Saber da linguagem & Saber da historiai da ciência & Saber da visiāo da ciência & $\mid$ Saber das concepsçess atternativas & $\begin{array}{c}\text { Saber sobre a historia da } \\
\text { instituiçó }\end{array}$ & $\begin{array}{l}\text { Saber da interacasa com o } \\
\text { professor }\end{array}$ & Saber da conexaró & $\begin{array}{c}\text { Saber da historia da } \\
\text { humanididade }\end{array}$ \\
\hline 噌 & Sited do labobratorio & 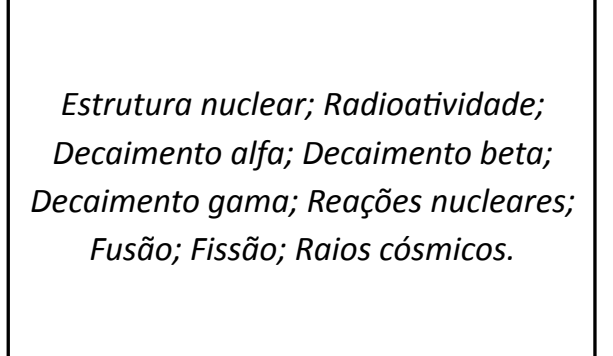 & & 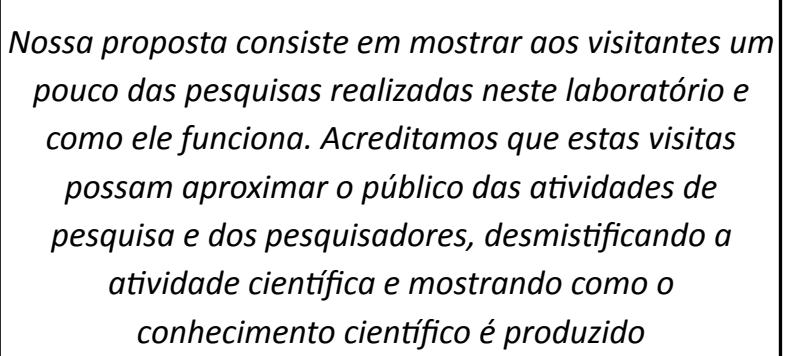 & & & & & & & & \\
\hline$\sum_{\bar{D}}^{\mathrm{D}}$ & Apresentatacâo Multimidia & 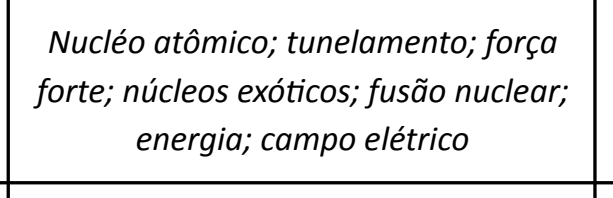 & 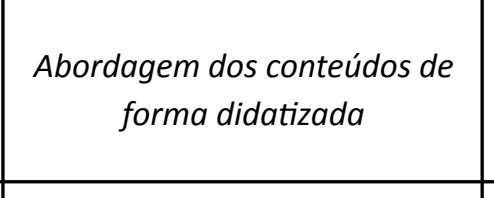 & & 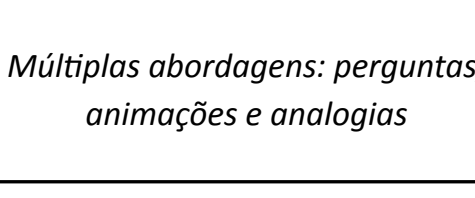 & & & & & & & \\
\hline & prototiono & 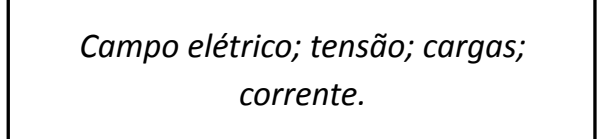 & 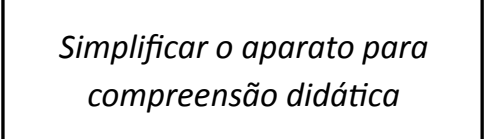 & & & & & & & & 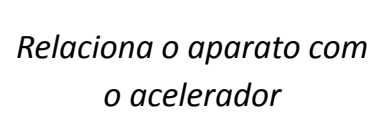 & \\
\hline Categorias & & saber discipininar & 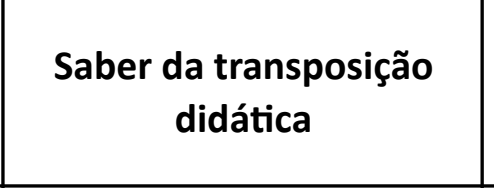 & Saber do dialalgog & Saber da linguagem & Saber da historial a a ciencia & Saber da visiōo da ciência & Saber das conceps.ses a aterenativis & $\begin{array}{c}\text { Saber sobre a historia da } \\
\text { instituifoso }\end{array}$ & $\begin{array}{l}\text { Saber da interasgo como } \\
\text { professor }\end{array}$ & Saber da conexầo & $\begin{array}{c}\text { Saber da historia da } \\
\text { humanidade }\end{array}$ \\
\hline 递 & Fala dos pesquisadores & 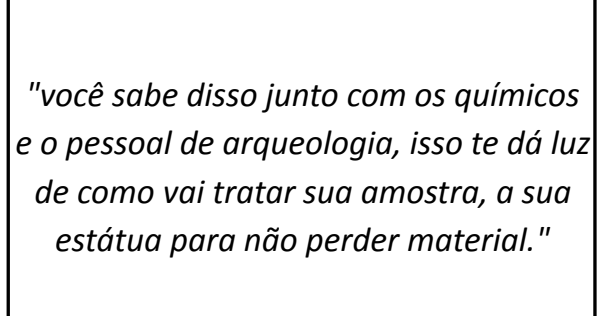 & & 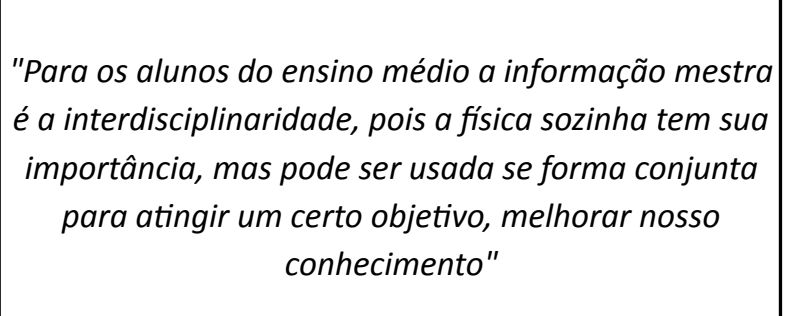 & 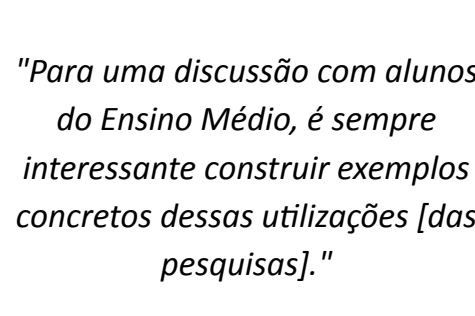 & & & 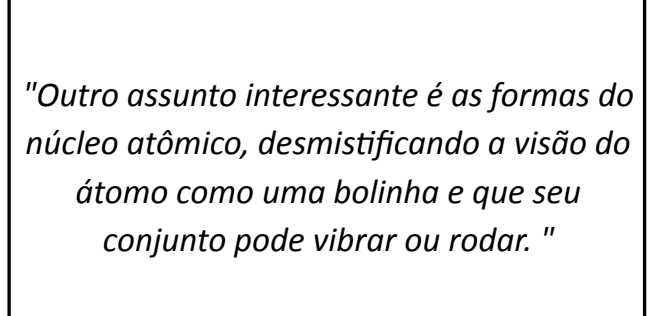 & & & & \\
\hline 噌 & Entradada no laboratotrio & 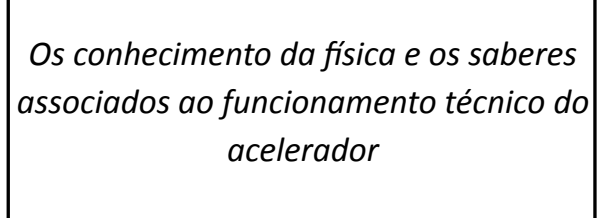 & & & & & & & 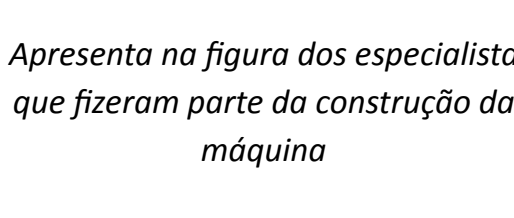 & & & \\
\hline
\end{tabular}

